FACULDADE DE ECONOMIA, ADMINISTRAÇÃO E CONTABILIADE DEPARTAMENTO DE ADMINISTRAÇÃO

PROGRAMA DE PÓS-GRADUAÇÃO EM ADMINISTRAÇÃO

ABORDAGEM DA CADEIA DE SUPRIMENTOS NA PERSPECTIVA DAS DIMENSÕES DA ESTRUTURA ORGANIZACIONAL: UM ESTUDO DE CASO NA CADEIA DE SERVIÇOS LOGÍSTICOS

Luiz Daniel Maffei Matsumato

Orientador: Prof. Dr. Alvair Silveira Torres Junior

SÃO PAULO 
Prof. Dr. Marco Antonio Zago

Reitor da Universidade de São Paulo

Prof. Dr. Adalberto Américo Fischmann

Diretor da Faculdade de Economia, Administração e Contabilidade

Prof. Dr. Roberto Sbragia

Chefe do Departamento de Administração

Prof. Dr. Moacir de Miranda Oliveira Junior

Coordenador do Programa de Pós-Graduação em Administração 


\title{
ABORDAGEM DA CADEIA DE SUPRIMENTOS NA PERSPECTIVA DAS DIMENSÕES DA ESTRUTURA ORGANIZACIONAL: UM ESTUDO DE CASO NA CADEIA DE SERVIÇOS LOGÍSTICOS
}

\author{
Dissertação apresentada ao Programa de Pós- \\ Graduação em Administração da Faculdade \\ de Economia, Administração e Contabilidade \\ da Universidade de São Paulo, para obtenção \\ do título de Mestre em Ciências.
}

Orientador: Prof. Dr.Alvair Silveira Torres Junior

\section{Versão Corrigida}

(versão original disponível na Faculdade de Economia, Administração e Contabilidade)

\section{SÃO PAULO}


FICHA CATALOGRÁFICA

Elaborada pela Seção de Processamento Técnico do SBD/FEA/USP

Matsumato, Luiz Daniel Maffei

Abordagem da cadeia de suprimentos na perspectiva das dimensões da estrutura organizacional : um estudo de caso na cadeia de serviços logísticos / Luiz Daniel Maffei Matsumato. -- São Paulo, 2014.

$229 \mathrm{p}$.

Dissertação (Mestrado) - Universidade de São Paulo, 2014.

Orientador: Alvair Silveira Torres Junior.

1. Estrutura organizacional 2. Logística 3. Distribuição física do estoque 4. Indústria farmacêutica I. Universidade de São Paulo.

Faculdade de Economia, Administração e Contabilidade. II. Título.

$\mathrm{CDD}-658.1$ 
À minha esposa e aos meus pais. 


\section{AGRADECIMENTOS}

À Deus, Jesus, pela vida e salvação.

À minha esposa Kamila pelo apoio e amor, ao meu pai Luiz Catsumi pelo suporte e amor, a minha mãe Laura Renata pelo amor e valores, ao meu tio Romeu e minha tia Cleony por conselhos e orações e minhas irmãs Cris e Bia por todo cuidado.

Aos meus amigos Victor França e Suzi Suyama, os quais em todas as situações sempre estiveram dispostos a ajudar.

Ao meu orientador Prof. Dr. Alvair Silveira Torres Junior por todas as instruções, sem as quais seria impossível a realização desta pesquisa.

Âs empresas e entrevistados que de forma muito atenciosa colaboraram com seu tempo e conhecimentos para a execução deste trabalho. 


\section{RESUMO}

As empresas sempre estão em busca de melhorias, eficácia e maior eficiência, por isso desde 1980 as empresas vêm investindo em eficiência de sua produção por meio de estratégias como just-in-time, kanban, produção enxuta, gestão da qualidade total, porém atualmente estas empresas percebem que precisam encontrar novos caminhos, assim a gestão da cadeia de suprimentos ganhou destaque na academia e no meio corporativo. Para acompanhar esta evolução na gestão das cadeias de suprimentos, os pesquisadores desenvolveram novos modelos para analisar e compreender seu comportamento e operação, em busca de novos patamares de desempenho. Assim, surgiram diversos modelos de análise, muitos destes se utilizam de conceitos de outras áreas. Estes novos conhecimentos oriundos de diversas áreas foram utilizados no estudo da gestão de cadeias, recentemente as teorias que foram desenvolvidas para a organização ganharam destaque quando utilizadas em um novo contexto, a gestão da cadeia de suprimentos. Esta pesquisa investiga como os conceitos de Estrutura Organizacional podem ajudar na gestão da cadeia de suprimentos, bem com explicar sua operação e comportamento. Para tanto, por meio de um estudo de caso, foi feita uma pesquisa de caráter qualitativo para entender na prática o que a teoria tem prescrito. $\mathrm{O}$ caso escolhido foi o de uma cadeia de distribuição de medicamentos, com uma das maiores indústrias farmacêuticas do mundo que trabalha em conjunto com um dos maiores operadores logísticos do mundo. Foram escolhidas as dimensões estruturais mais frequentes, centralização, complexidade, formalização e integração. Entre os principais achados podem ser destacados as dificuldades de aplicar plenamente alguns conceitos da teoria de Estrutura Organizacional. As discussões sobre as diferenças entre os contextos organizacionais e das cadeias evoluem conforme os conceitos de estrutura demonstram não serem plenamente aplicáveis neste novo contexto. Questões como a centralização do poder na alta gestão (hierarquia mais alta de uma empresa) são questionadas quando o acumulo do poder em um alto nível hierárquico não é encontrado, mas sim é dividido entre 3 ou mais agentes. A companhia aérea mostrou grande centralização do poder, mesmo estando quatro níveis abaixo da indústria que segundo a literatura é o equivalente a alta gestão dentro da organização. Diversas explicações são propostas, por exemplo, o efeito da baixa concorrência e a não exclusividade na prestação de serviços. Esta investigação demonstra que a utilização de conceitos da estrutura organizacional explica até certo grau o comportamento da cadeia de suprimentos, mas diversas outras variáveis e questões surgem conforme essas teorias não são capazes de explicar todos os fenômenos, assim são sugeridas novas pesquisas para que a utilização desta teoria possa gerar melhor entendimento e colabore para uma melhor gestão da cadeia de suprimentos. Uma limitação encontrada nesta pesquisa foi o número de agentes participantes da cadeia, não foram entrevistados alguns agentes que possivelmente iriam elucidar mais entendimentos, por exemplo, o cliente final e as companhias aéreas.

Palavras-chave: estrutura organizacional; logística; distribuição física do estoque; indústria farmacêutica 


\begin{abstract}
Companies are always looking for improvements, greater efficiency and effectiveness, since 1980 companies have been investing in their production efficiency through strategies like just-in-time, kanban, lean manufacturing, total quality management, but currently these companies realize they need to find new ways, therefore supply chain management gained prominence in academy and corporate environment. Contributing to this evolution in the supply chain management, researchers developed new models to analyze and understand the behavior and operation of supply chains in order to achieve better supply chain performance. Thus, several different models of analysis have been developed, many of these models make use of concepts from other knowledge fields. These new knowledge from different disciplines were used to study the management of the supply chain, recently theories that have been developed for intra-organization environment gained prominence for its use in the context of supply chain management. This research investigates how the concepts of organizational structure can help in managing the supply chain, as well as explain its operation and behavior. Through a case study, a qualitative research study was developed to understand in practice what theory has prescribed. The chosen case is a chain of medicines distribution, lead by one of the largest pharmaceutical industries in the world, operating together with one of the largest third party logistics in the world. The most frequent structural dimensions, centralization, complexity, formalization, integration and specialization were chosen as lens to study this case. Among the main findings, difficulties to fully implement some concepts of the theory of Organizational Structure can be highlighted. The discussions about the differences between the organizational and the supply chain environment evolve as the concepts of structure cannot explain the chain behavior. Dimensions like centralization of power in top management are questioned when the context of the chain are analyzed, as an example an airline company showed great centralization of power, even though it is four levels below pharmaceutical industry, which is the equivalent of senior management within the organization, according to the literature. Several explanations are proposed, for example, the effect of low competition and non-exclusivity in the provision of logistics services. This research demonstrates that the use of concepts of organizational structure explains to some extent the behavior of the supply chain, but other variables and questions arise as this theory are unable to explain the supply chain phenomenon. Insights for further research are suggested in order to generate better understanding and collaborate in the evolution of supply chain management. Finally some limitations were found in this study, there are a large number of agents participating in the chain, but not all of them were interviewed. Therefore some agents, who would possibly elucidate more understanding, should be interviewed in future research, for example, the end customer and airlines.
\end{abstract}

Keywords: organizational structure, logistics; distribution of physical goods; pharmaceutical industry 



\section{Sumário}

1. INTRODUÇÃ̃ ........................................................................................ 17

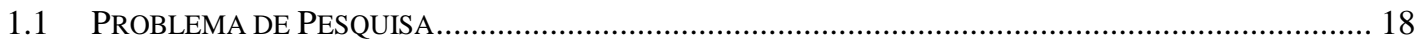

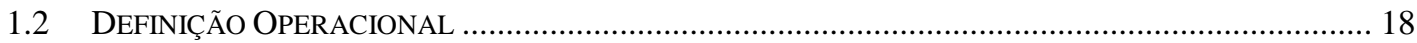

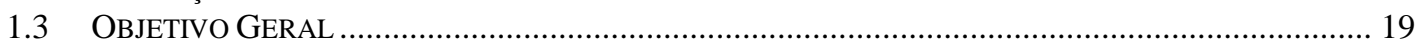

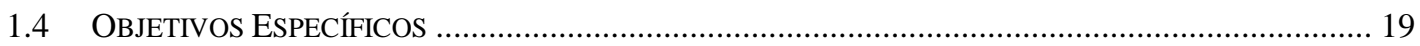

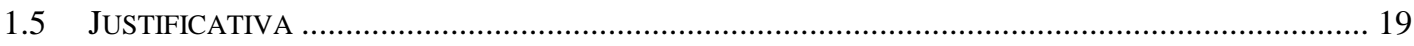

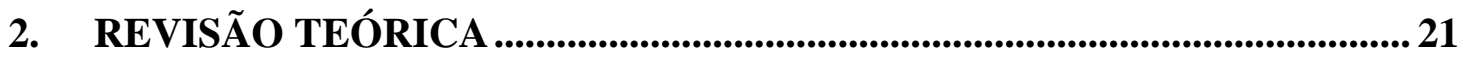

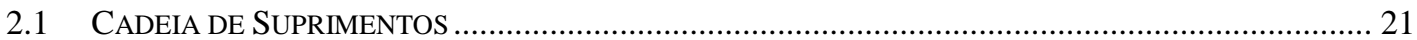

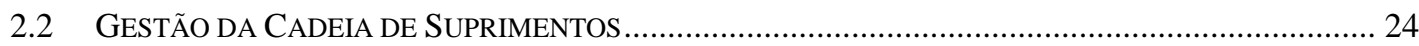

2.3 CADEIA DE SERVIÇOS .......................................................................................... 24

2.4 OCORRÊNCIA DAS DIMENSÕES ESTRUTURAIS NAS ABORDAGENS ATUAIS ............................. 29

2.5 TEORIA ORGANIZACIONAL E A GESTÃo DA CADEIA DE SUPRIMENTOS ..................................... 33

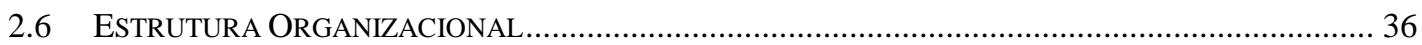

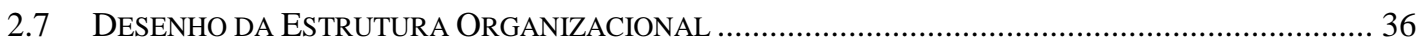

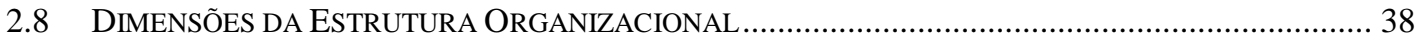

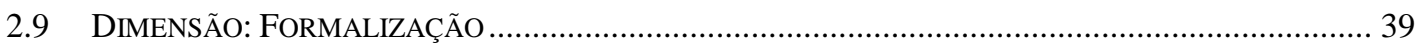

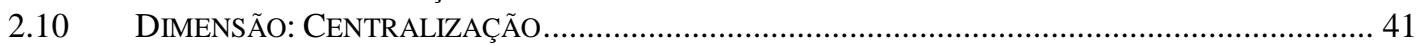

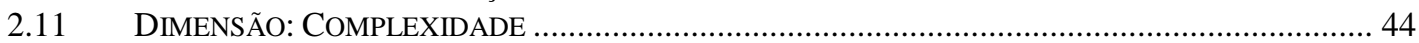

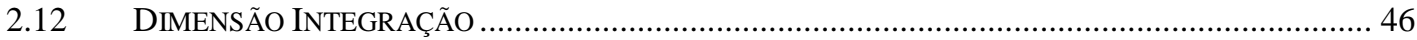

2.13 DIMENSÕES DA ESTRUTURA ORGANIZACIONAL NA CADEIA DE SUPRIMENTOS ....................46 46

2.14 DIMENSÕES ESTRUTURAIS E SUA APLICAÇÃO NA CADEIA DE SUPRIMENTOS........................49

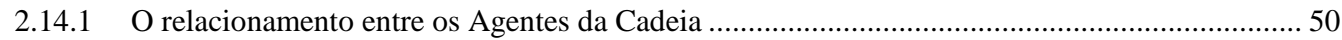

2.14.1.1. Alianças, Parcerias, Cooperação e Colaboração...................................................................... 50

2.14.1.2. Dificuldades e Barreiras à Colaboração na Cadeia de Suprimentos ....................................... 51

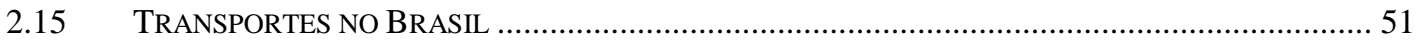

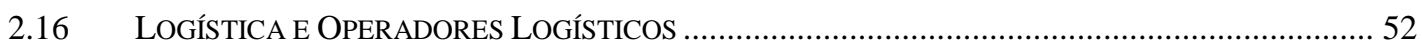

3. METODOLOGIA ….........................................................................................5

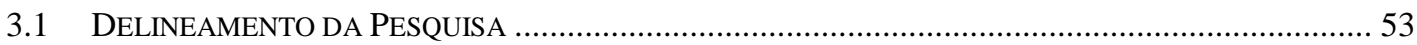

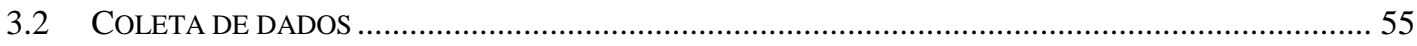

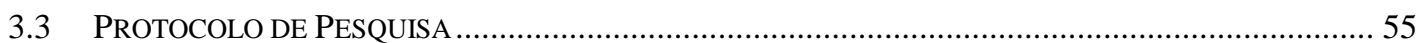

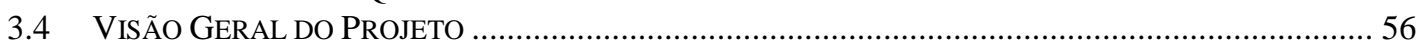

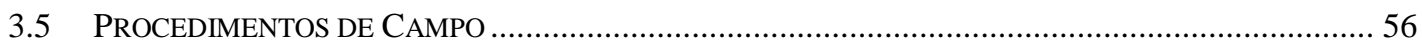

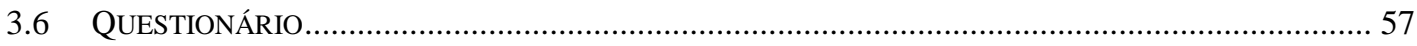

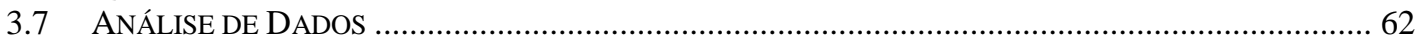

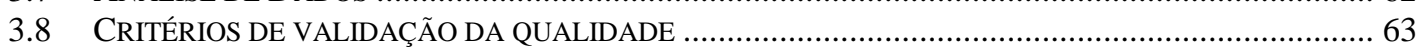

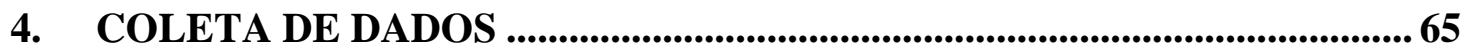

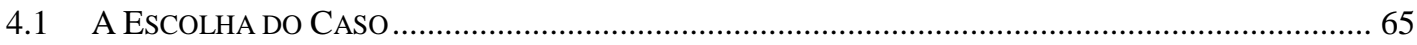

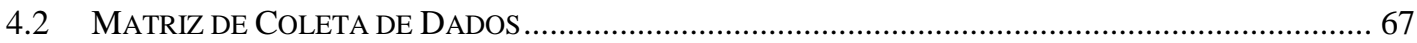

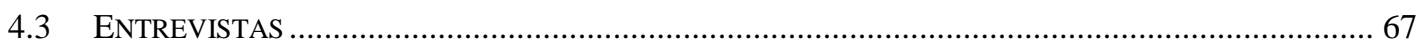

5. ANÁLISE DE DADOS......................................................................................... 69

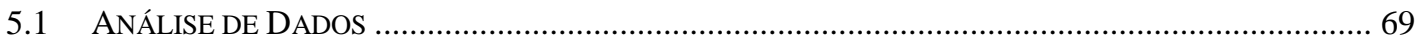

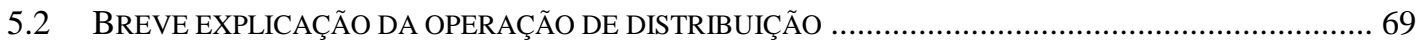

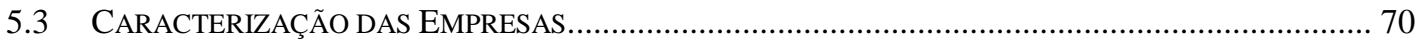

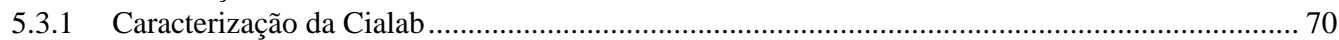

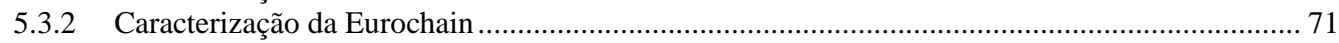

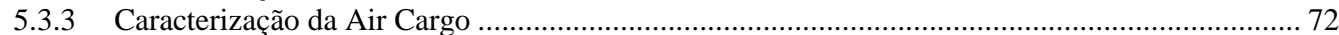

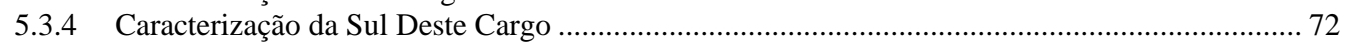

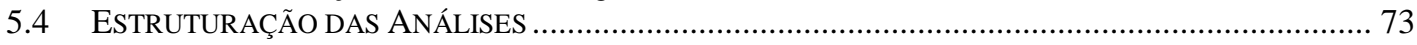

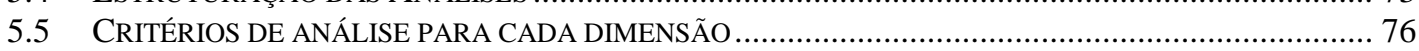

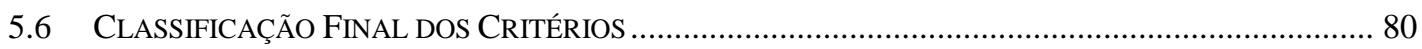

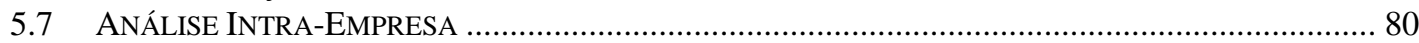

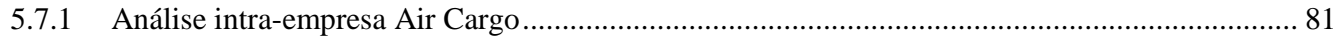

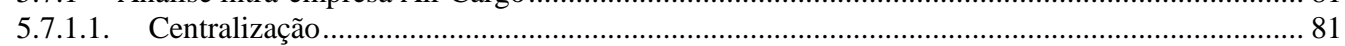


5.7.1.1.1. Relacionamento Air Cargo - Eurochain ............................................................................ 81

5.7.1.1.2. Relacionamento Air Cargo - Transportadores Rodoviários ……......................................... 84

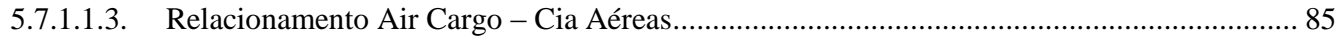

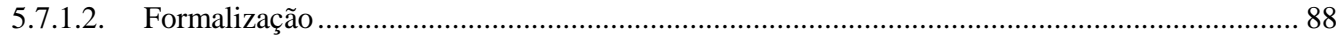

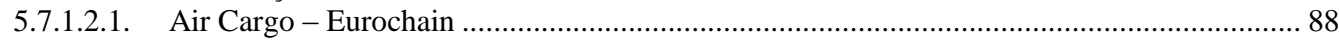

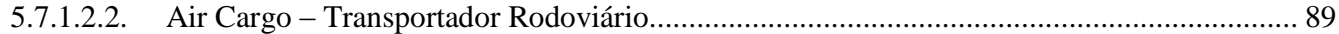

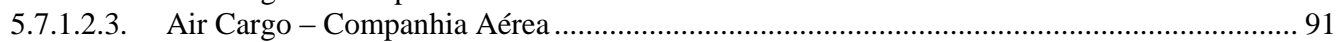

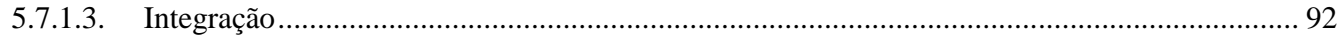

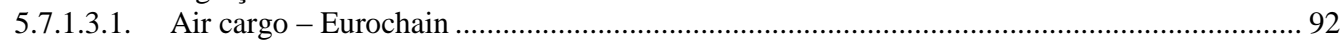

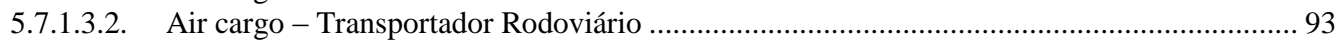

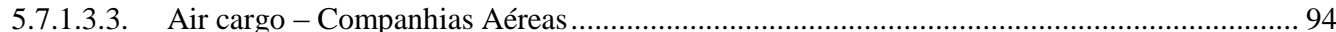

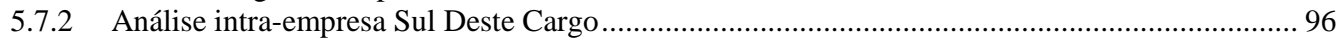

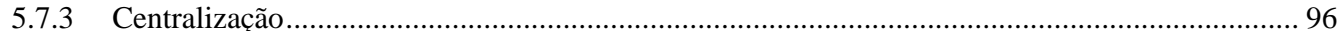

5.7.3.1. Relacionamento Sul Deste Cargo - Eurochain....................................................................... 96

5.7.3.2. Relacionamento Sul Deste Cargo - Transportadores ............................................................ 97

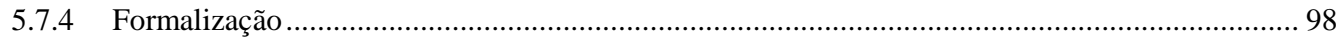

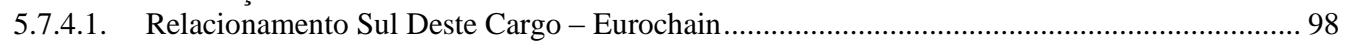

5.7.4.2. Relacionamento Sul Deste Cargo - Transportadores ............................................................ 99

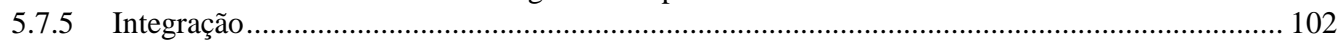

5.7.5.1. Relacionamento Sul Deste Cargo - Eurochain................................................................... 102

5.7.5.2. Relacionamento Sul Deste Cargo - Transportadores ....................................................... 103

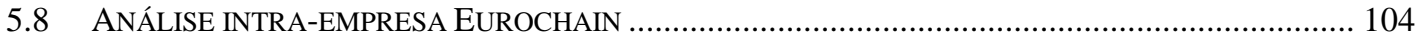

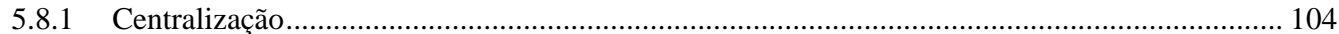

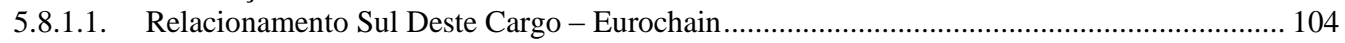

5.8.1.2. Relacionamento Eurochain - Transportadores .................................................................... 106

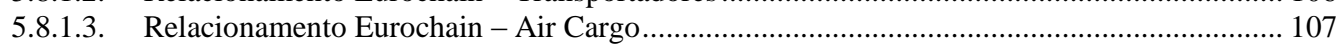

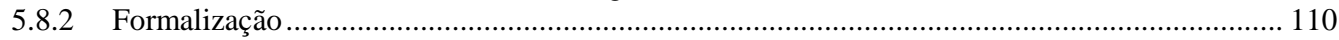

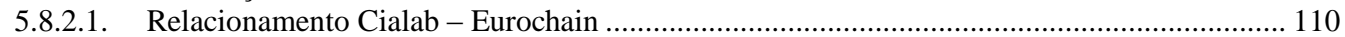

5.8.2.2. Relacionamento Sul Deste Cargo - Eurochain.................................................................. 111

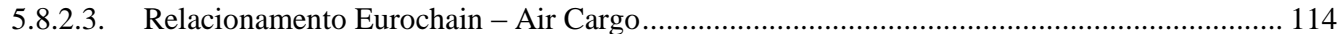

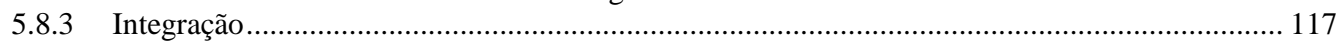

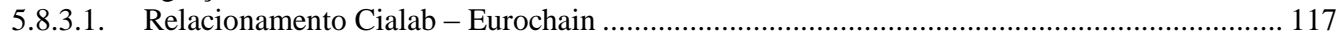

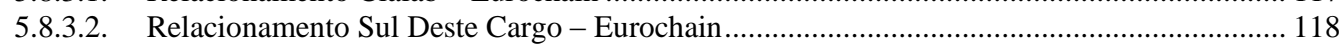

5.8.3.3. Relacionamento Eurochain - Air Cargo ..................................................................... 120

5.9 ANÁLISE INTRA-EMPRESA CIALAB ..................................................................... 121

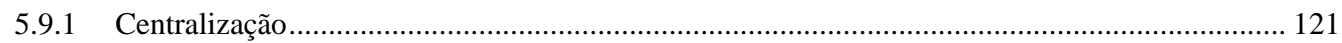

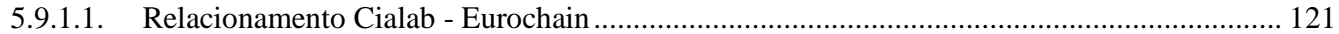

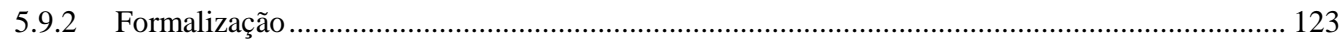

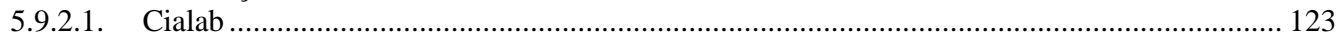

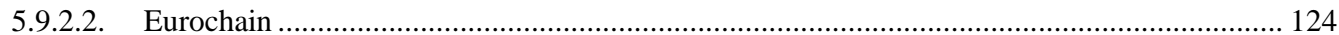

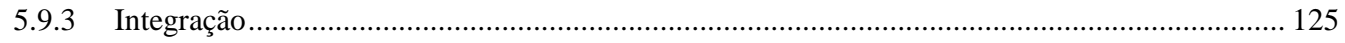

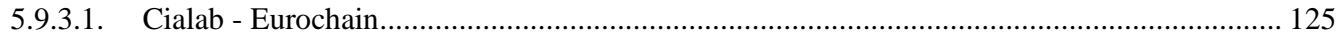

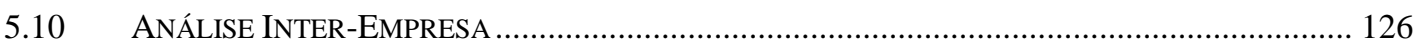

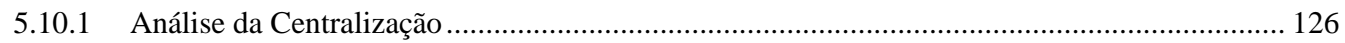

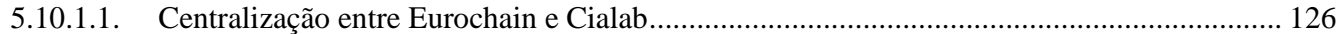

5.10.1.2. Centralização entre Eurochain e Air Cargo ...................................................................... 129

5.10.1.3. Centralização entre Air Cargo e Companhias Aéreas............................................................ 132

5.10.1.4. Centralização entre Air Cargo e Transportadores Rodoviários ................................................ 133

5.10.1.5. Centralização entre Sul Deste Cargo e Eurochain .............................................................. 134

5.10.1.6. Centralização entre Sul Deste Cargo e Transportadores........................................................ 136

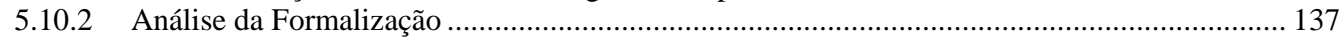

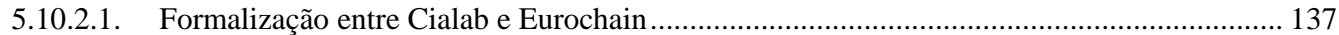

5.10.2.2. Formalização entre Eurochain e Air Cargo ............................................................................ 138

5.10.2.3. Formalização entre Air Cargo e Companhias Aéreas ........................................................ 140

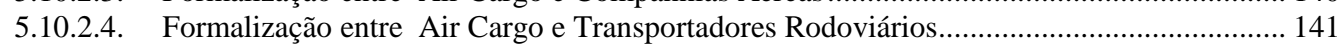

5.10.2.5. Formalização entre Eurochain e Sul Deste Cargo ........................................................... 142

5.10.2.6. Formalização entre Sul Deste Cargo e Transportadores Rodoviários................................... 143

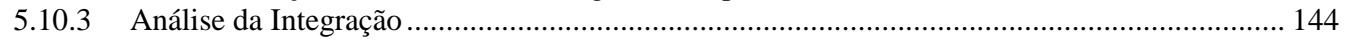

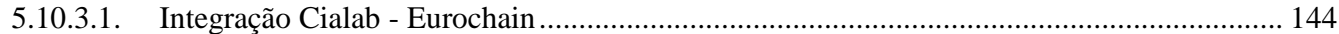

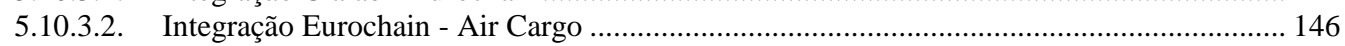

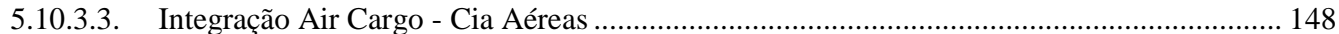

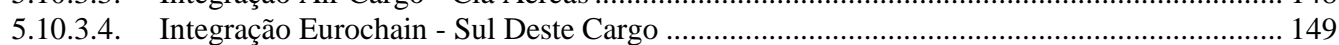

5.10.4.1. Integração Sul Deste Cargo - Transportadores Rodoviários................................................ 151

5.10.4.2. Integração Air Cargo - Transportadores Rodoviários...................................................... 152

5.11.1 Destaque sobre Poder do Destinatário Final......................................................................... 153

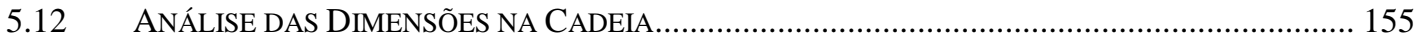

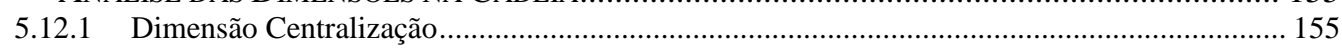

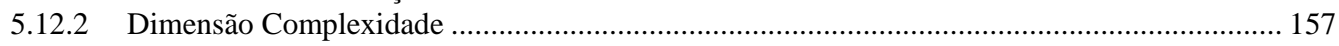




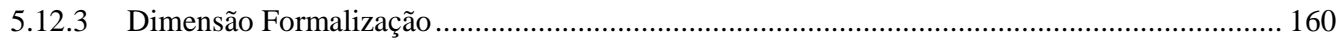

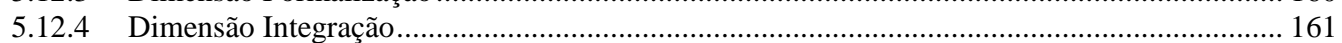

6. CONCLUSÃO ..................................................................................................... 162

7. BIBLIOGRAFIA ................................................................................................. 171

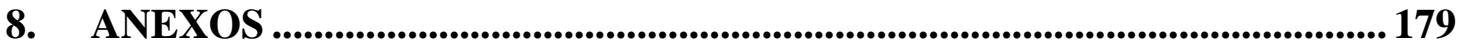

8.1 ANEXOS I - TABELA DOS MELHORES JOURNALS DE OPERAÇÕES E SUPPLY CHAIN (WEBQUALIS 179

8.2 ANEXOS II - ENTREVISTAS 1 EUROCHAIN ............................................................... 179

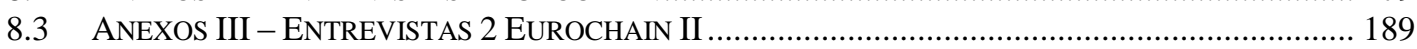

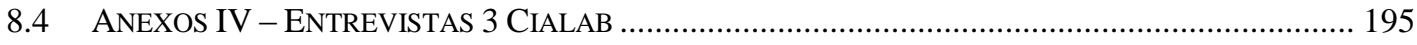

8.5 ANEXOS V - ENTREVISTAS 4 SUl DESTE CARGO............................................................. 203

8.6 ANEXOS VI - ENTREVISTAS 5 AIR CARGO .................................................................... 210

8.7 ANEXOS VII - LISTA DOS ARTIGOS SOBRE ABORDAGENS DA CADEIA ................................. 220

8.8 ANEXOS VIII - ASPECTOS DA ESTRUTURA DA CADEIA DE SUPRIMENTOS IDENTIFICADOS POR ARTIGO 225 


\section{Índice de Ilustrações}

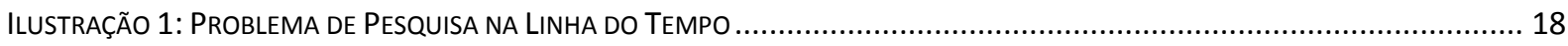

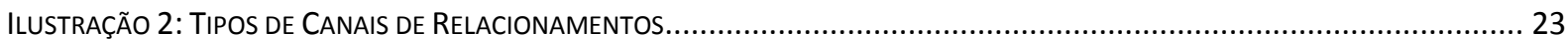

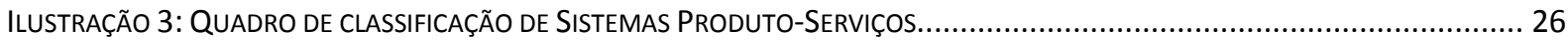

ILUSTRAÇÃO 4: QUADRO COM EXEMPLOS DE SERVIÇOS PARA CADA NÍVEL DE INTANGIBILIDADE. ...........................................28

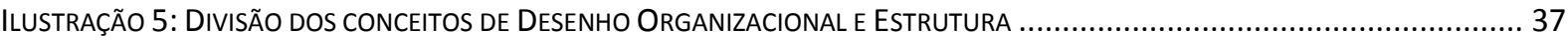

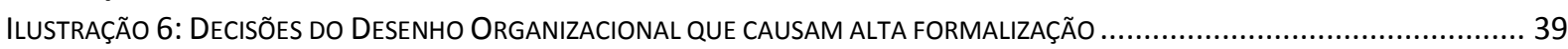

ILUSTRAÇÃo 7: DECISÕES DO DESENHO ORGANIZACIONAL QUE CAUSAM ALTA CENTRALIZAÇÃO ................................................ 42

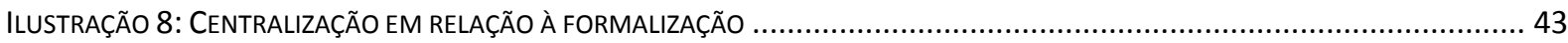

ILUSTRAÇÃO 9: DECISÕES DO DESENHO ORGANIZACIONAL QUE CAUSAM ALTA COMPLEXIDADE ................................................44

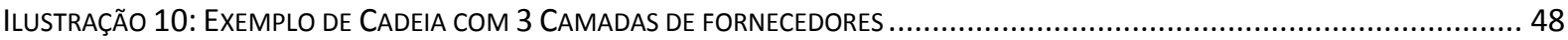

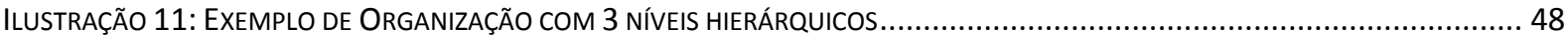

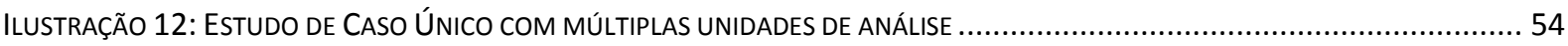

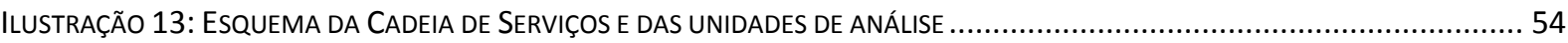

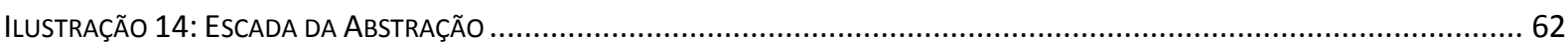

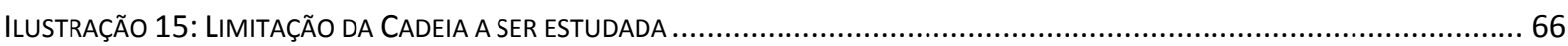

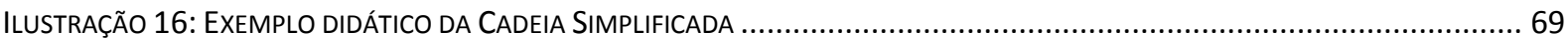

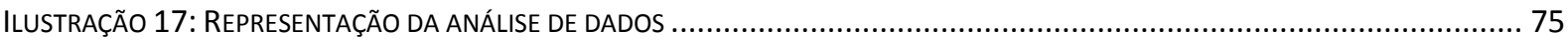

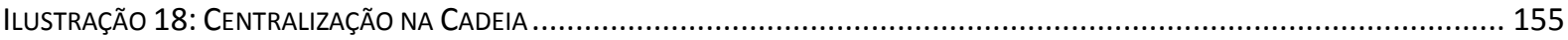

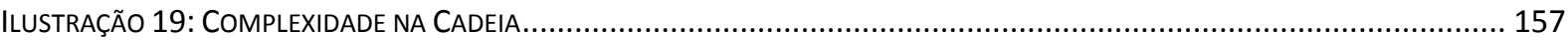

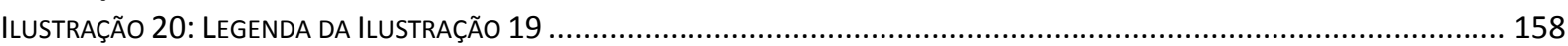

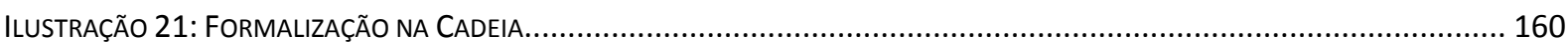

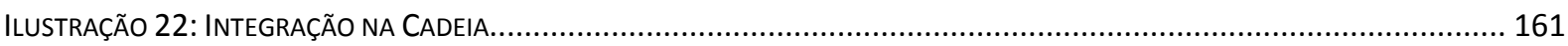

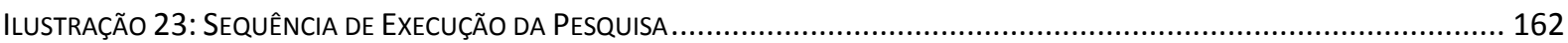




\section{Índice de Tabelas}

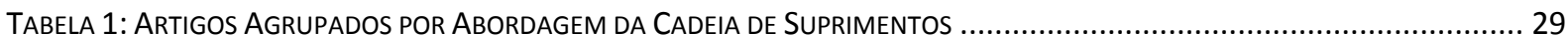

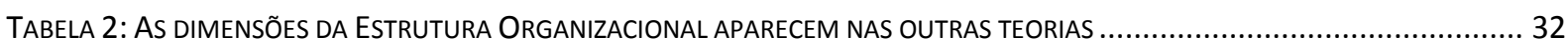

TABELA 3: OUTRAS DIMENSÕES QUE POSSUEM RELAÇÃO COM AS DIMENSÕES DA ESTRUTURA ORGANIZACIONAL............................33

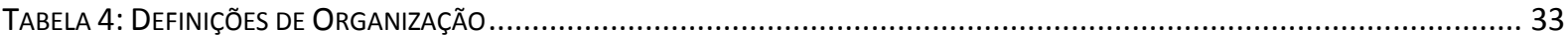

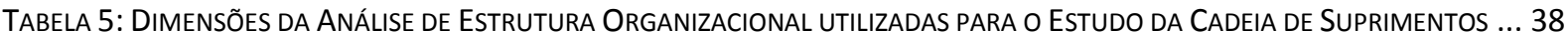

TABELA 6: DIMENSÕES DA ESTRUTURA ORGANIZACIONAL E SUA APLICAÇÃO No CONTEXTO DE CADEIA DE SUPRIMENTOS .............. 49

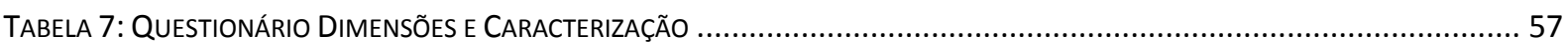

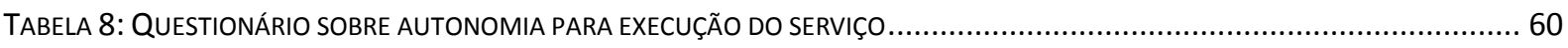

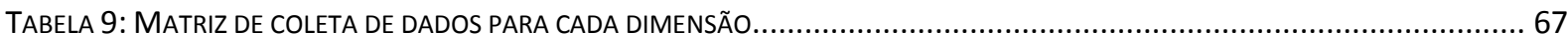

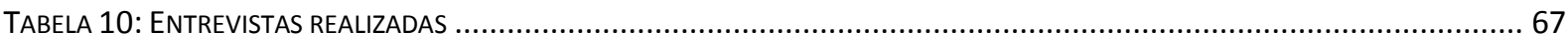

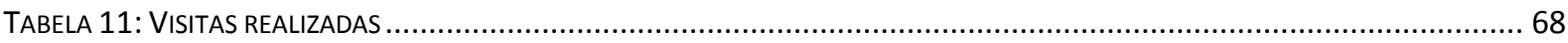

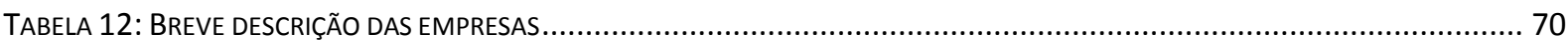

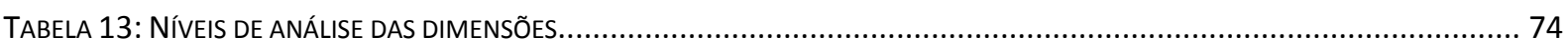

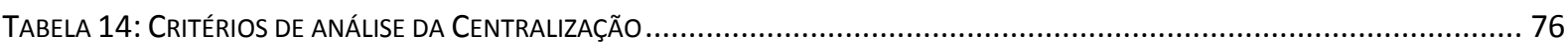

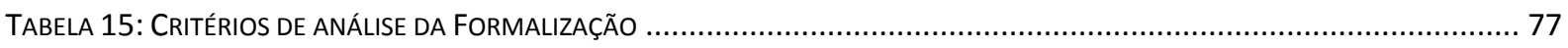

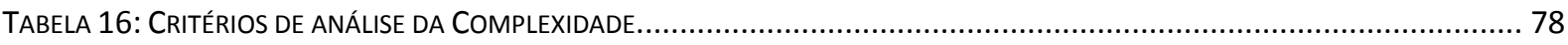

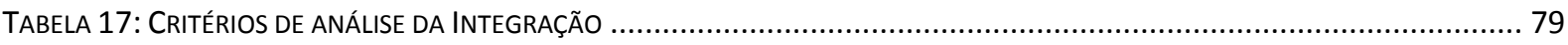

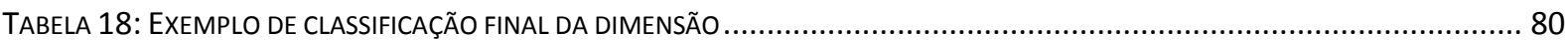

TABELA 19: LEGENDAS PARA DIFERENCIAR TRECHOS ORIUNDOS DAS VISITAS, DOCUMENTOS E ENTREVISTAS.............................. 80

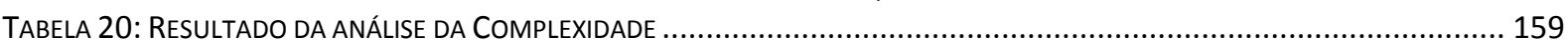

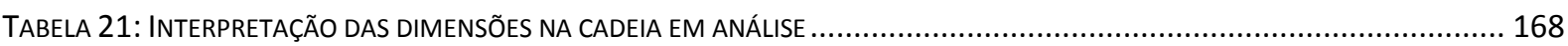




\section{INTRODUÇÃO}

Desde 1980, as empresas vêm investindo em eficiência de sua produção por meio de estratégias como just-in-time, kanban, produção enxuta, gestão da qualidade total, entre outras, porém nos últimos anos notaram que já haviam reduzido fortemente seus custos de produção e, agora, seria necessário desenvolver novos caminhos para melhorias. Algumas dessas empresas já perceberam que este caminho é investir na gestão eficiente da cadeia de suprimentos (SIMCHI-LEVI, KAMINSKY e SIMCHI-LEVI, 2010).

Deste modo, a gestão da cadeia de suprimentos ganhou ênfase, segundo Miles e Snow (2007). A evolução da gestão da cadeia de suprimentos passou por três fases. Por volta da década de 80, a ênfase foi a eficiência da cadeia, eficiência operacional entre as organizações que faziam parcerias, como indústria, seus fornecedores de produtos e serviços e seus clientes. Em um segundo momento, as indústrias começaram a perceber que, além da eficiência na produção, deveriam buscar com clareza o aumento de sua competitividade por meio da eficácia e, assim, desenvolveram relacionamentos com fornecedores com foco estratégico, a fim de incorporarem melhorias, novas ideias e melhores práticas de seus fornecedores e parceiros na gestão da cadeia. No atual momento, as empresas buscam formas de expandir estas cadeias, para que estas interajam com novas redes e novas indústrias, para operar com eficiência e eficácia entre indústrias diferentes.

Para acompanhar esta evolução na gestão das cadeias de suprimentos, os pesquisadores desenvolveram novos modelos para analisar e compreender os seus mecanismos e operação e para atingir novos patamares de desempenho. Assim, surgiram diversos modelos de análise como: Value Stream Mapping, Supply Chain Network Structure, Social Network Analysis, entre outros. Muitos destes modelos se utilizam de conceitos de outras áreas do conhecimento. Por exemplo, Social Network Analysis se utiliza da teoria dos Grafos, com origens na matemática computacional (KIM et al., 2010), ou ainda Complex Adaptative Systems, com origens na biologia evolucionária (CHOI, DOOLEY e RUNGSTUSANATHAM, 2001). Assim, conhecimentos oriundos de diversas áreas foram aplicados no estudo da gestão da cadeia de suprimentos. Recentemente, as teorias que foram desenvolvidas para o contexto da intraorganização ganharam destaque em sua aplicação no contexto de gestão da cadeia de suprimentos (ASHENBAUM, SALZARULO e NEWMAN, 2012).

Em 2006, um dos mais referenciados periódicos da área de operações, segundo avaliação do JCR - Journal Citation Reporst (Thomson Reuters), Journal of Operations Management, publicou um artigo de destaque sobre uma convocação especial de pesquisadores para a aplicação de teorias organizacionais no contexto de gestão de cadeias de suprimentos. Foram recebidas 46 submissões de artigos relacionados a este tema. Ketchen e Hult (2007), autores deste artigo, analisaram o impacto dos melhores artigos entre os 46 submetidos e apontam que as teorias organizacionais podem colaborar em novos questionamentos sobre a gestão da cadeia de suprimentos e gerar novos caminhos para a pesquisa, por isso incentivam fortemente a utilização de teorias organizacionais no contexto da cadeia de suprimentos. Miles e Snow (2007), Choi e Hong (2002), Ketchen e Hult (2010), Boyle, Humphreys e McIvor (2008), Hitt (2011), Bozarth et al. (2009), são alguns dos autores que recentemente aplicaram teorias organizacionais neste novo contexto.

Ketchen e Hult (2007), apesar de destacarem o potencial da utilização das teorias organizacionais, também apontam cuidados e questionam até que ponto uma cadeia de suprimentos pode ser comparada a uma organização. Ketchen e Hult (2010) destacam que 
algumas teorias não podem ser aplicadas no contexto de gestão da cadeia de suprimentos sem adaptações e outras simplesmente não devem ser aplicadas, pois pouco explicam sobre seus fenômenos. Uma destas teorias organizacionais que foram utilizadas no novo contexto referese ao uso dos conceitos de estrutura organizacional.

Nesta pesquisa será investigado como os conceitos da teoria de Estrutura Organizacional podem ser utilizados para compreender a gestão de cadeias de suprimentos. A Teoria de Estrutura Organizacional é uma teoria já bem estabelecida e consolidada em seu contexto original da intraorganização, porém esta ainda não foi vastamente explorada para o contexto da cadeia de suprimentos. A teoria em questão é adequada para ser analisada, pois além de ser uma teoria robusta, muitos de seus conceitos apresentam reflexos nos métodos de análise de cadeia de suprimentos. Por exemplo, o conceito organizacional por trás da dimensão centralização também pode ser encontrado nas teorias Supply Chain Network Structure e Social Network Analysis. Esta dimensão diz respeito à divisão do poder nos relacionamentos entre os agentes da cadeia, levando em consideração a centralização da tomada de decisão em uma das organizações com maior influência na cadeia. Outros conceitos desta teoria também são encontrados nos métodos já estabelecidos para as cadeias de suprimento. Isso demonstra que a análise por meio das dimensões da Estrutura Organizacional apresentará coerência em sua aplicação no contexto da cadeia de suprimentos e assim será possível realizar a pesquisa, uma vez que haverá pelo menos alguma aderência desta para o novo contexto.

O objetivo desta pesquisa é entender a aplicação - suas oportunidades e limitações dos elementos da teoria de Estrutura Organizacional na gestão da cadeia de suprimentos, por meio de um estudo de caso e uma pesquisa de caráter qualitativo, para entender na prática o que a teoria tem prescrito.

\subsection{Problema de Pesquisa}

Como as dimensões estruturais concebidas em um contexto de administração intraorganizacional de empresas se manifestam em sua aplicação na gestão da cadeia de suprimentos? Quais benefícios, limitações e oportunidades? A figura 1 ilustra esta pergunta.

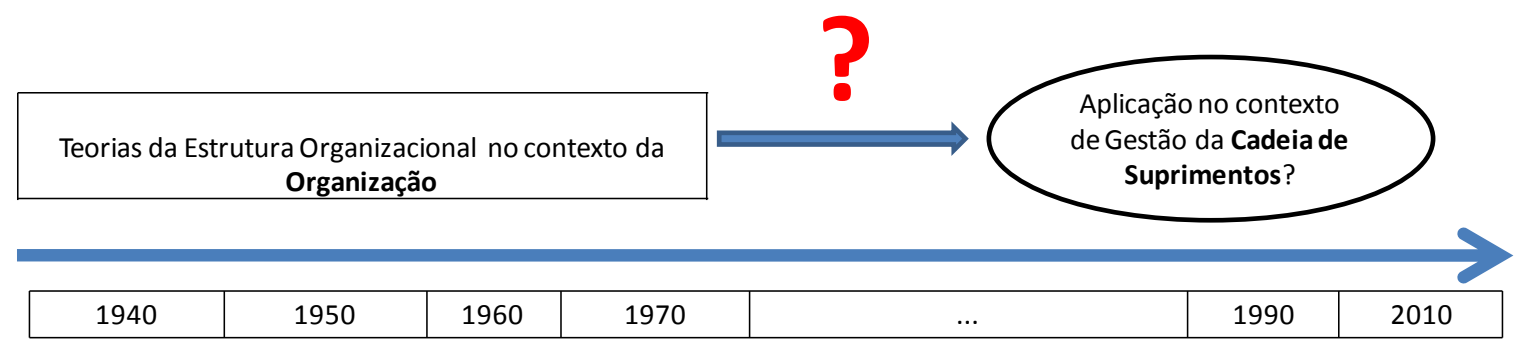

Ilustração 1: Problema de Pesquisa na Linha do Tempo

\subsection{Definição Operacional}

Dimensões Estruturais: a estrutura organizacional é uma forma de controle e organização das pessoas, atividades e grupos (GIBSON, IVANCEVICH e DONNELLY, 
1991), os componentes identificados nesta estrutura são chamados dimensões estruturais, por exemplo, complexidade, formalização, centralização e integração.

\subsection{Objetivo Geral}

Este trabalho tem por objetivo responder às questões:

- Como as dimensões da Estrutura Organizacional contribuem na gestão da Cadeia de Serviços Logísticos?

- O que elas explicam sobre a operação e comportamento da Cadeia de Serviços Logísticos e quais as limitações?

\subsection{Objetivos Específicos}

Para responder ao objetivo geral, três objetivos específicos precisam ser alcançados:

- Identificar as principais dimensões da análise de Estrutura Organizacional que são utilizadas pelas abordagens da Cadeia de Suprimentos.

- Identificar uma cadeia de serviços logísticos e mapear seus agentes.

- Descrever a Cadeia de Serviços Logísticos sob a perspectiva das dimensões da Estrutura Organizacional, apresentando suas limitações, forma de aplicação e oportunidades.

\subsection{Justificativa}

A literatura aponta a necessidade de estudos que descrevam comportamento de cadeias de suprimentos, sejam elas de produtos tradicionais ou de serviços. Segundo Choi e Hong (2002), os pesquisadores ainda estão em estágio inicial de compreensão de como uma cadeia opera e se comporta.

Esta pesquisa, além de preencher este espaço do conhecimento da cadeia de suprimentos, também caminha na direção apontada por Ketchen e Hult (2006) os quais incentivam o desenvolvimento da aplicação de Teorias Organizacionais no contexto da Gestão da Cadeia de Suprimentos. Estes autores apontam que existem grandes oportunidades para a integração entre as teorias organizacionais e as teorias da Gestão da Cadeia, a fim de compreender as razões que levam algumas cadeias superarem outras.

Este trabalho utilizará como caso uma cadeia de serviços logísticos. Conforme Akkermans e Voss (2013), é grande a importância do campo de operações de serviços para a pesquisa e apontam outros diversos autores que ressaltam a importância deste tema. Giannakis (2011) também aponta a necessidade de pesquisa em Cadeias de Suprimento de Serviços. Embora os serviços de marketing e gestão de operações de serviços tornaram-se campos de pesquisa estabelecidos e desenvolveram conhecimentos sofisticados e inovadores para a produção e prestação de serviços, poucos estudos investigaram como prestadores de serviços podem criar valor por meio da integração dos processos que vão além de suas fronteiras, estudando suas cadeias. 
A escolha de um caso no setor logístico se justifica devido à importância do setor, no Brasil. Segundo Pesquisa Anual de Serviços 2011 do IBGE, o setor de transporte representa em torno de $30 \%$ de toda receita líquida do setor de serviços do país, sendo que serviços representam em torno de $70 \%$ do PIB nacional. O transporte rodoviário corresponde a 52,0\% da receita líquida do setor de transportes gerais ou $\mathrm{R} \$ 149,9$ bilhões, segundo Pesquisa Anual de Serviços 2011 do IBGE.

Considerando a importância deste setor para o país, é importante que existam pesquisas que possam melhorar o entendimento do setor, inclusive cadeias de distribuição, como é o caso desta pesquisa. Pesquisas sobre a distribuição são raras, porém muito importantes e este é mais um ponto que justifica a escolha do caso. Cirtita e Glaser-Segura (2012) também reforçam a necessidade de que mais estudos à jusante das cadeias sejam desenvolvidos. 


\section{REVISÃO TEÓRICA}

Os dois pilares deste trabalho são a gestão da cadeia de suprimentos e a aplicação da teoria de Estrutura Organizacional ao contexto das cadeias. Primeiramente será desenvolvido o referencial teórico referente a cadeias de suprimentos. Em seguida serão discutidas quais são as dimensões da estrutura que ocorrem nas análises de cadeia de suprimentos. Será também abordada a teoria Organizacional com foco na Estrutura Organizacional. Por último serão trabalhados os temas de Transportes no Brasil, Logística e Operadores Logísticos.

\subsection{Cadeia de Suprimentos}

Segundo Mabert e Venkataramanan (1998), a Cadeia de Suprimentos é uma série de unidades que transformam matéria-prima em produtos acabados e os entregam para os clientes. Para Miles e Snows (2007), Cadeia de Suprimentos é a rede de empresas que contribuem para o envio e recebimento de produtos e serviços da cadeia de valor industrial.

O desenvolvimento e a operação de Cadeias de Suprimentos tornaram-se importantes temas para acadêmicos, o que resultou em um aumento de definições. Cadeia de Suprimentos como um processo estruturado de manufatura no qual matérias-primas são transformadas em produtos acabados e então serem entregues para os clientes (BEAMON, 1998). Para Pienaar (2009), a Cadeia de Suprimentos também se define como a descrição geral de um processo de integração envolvendo organizações para transformar matérias-primas em produtos acabados e transportá-los para o usuário final. Este autor afirma que esta definição se concentra nos principais determinantes para uma Cadeia de Suprimentos efetiva.

Todas estas definições são muito semelhantes, considerando a transformação da matéria-prima e a entrega para o consumidor final. Little (1999) faz uma definição diferente. Para este autor a Cadeia de Suprimentos é o fluxo combinado e coordenado de materiais da origem até o destino, bem como o fluxo de informações que estão ligados aos materiais.

Chow e Heaver (1999) definem a Cadeia de Suprimentos como o grupo de manufaturas, fornecedores, distribuidores, varejistas e transportadores, provedores de serviços de informação e logística os quais estão envolvidos no envio de produtos para o cliente. Uma Cadeia de Suprimentos considera ambos associados internos ou externos a corporação.

Ayers (2001) define a Cadeia de Suprimentos como um processo de ciclo de vida envolvendo bens materiais, informação, e fluxos financeiros os quais tem como objetivo atender às demandas do cliente com bens e serviços de diversos fornecedores conectados.

Mentzer et al. (2001) definem a Cadeia de Suprimentos como um conjunto de entidades (por exemplo, organizações ou indivíduos) diretamente envolvidos no fornecimento e distribuição do fluxo de bens, serviços, finanças e informações de uma fonte para um destino. Existem diversas definições, porém utilizá-las para descrever a realidade pode ser complicado, aparentemente o que muitos autores consideram consenso é a alteração da matéria prima ao longo da cadeia.

Mentzer et al. (2001) também indica a segmentação de 3 graus de complexidade da Cadeia de Suprimentos (veja ilustração 2): 
- Cadeia de Suprimentos Direta - Esta envolve: Empresa, seu fornecedor e seu cliente e o fluxo montante e jusante de produtos, serviços e informações.

- Cadeia de Suprimentos Indireta - além dos agentes anteriores inclui também os fornecedores diretos dos seus fornecedores e os clientes diretos dos seus clientes e todos envolvidos no fluxo a montante jusante de produtos, serviços e informações.

- Cadeia de Suprimentos Máxima: Neste grau de complexidade todos os agentes envolvidos são considerados, todos os envolvidos nos fluxos de informações, produtos e serviços desde o primeiro fornecedor até o último cliente.

Mentzer et al. (2001) também aponta que essas estruturas de cadeia de suprimentos vão sempre existir, sendo que podem ou não estar sendo gerenciadas. Ou seja, independentemente do Gerenciamento da Cadeia de Suprimentos, a Cadeia de Suprimentos pode sempre existir. Mentzer et al. (2001) também ressalta que uma vez que as Cadeias podem se tornar muito complexas alguns agentes podem ser clientes e fornecedores e cada empresa pode participar simultaneamente em diversas cadeias. Dessa forma é importante notar que as cadeias podem começar a se parecerem com redes, ou seja, estruturas mais complexas que as de Cadeia. 


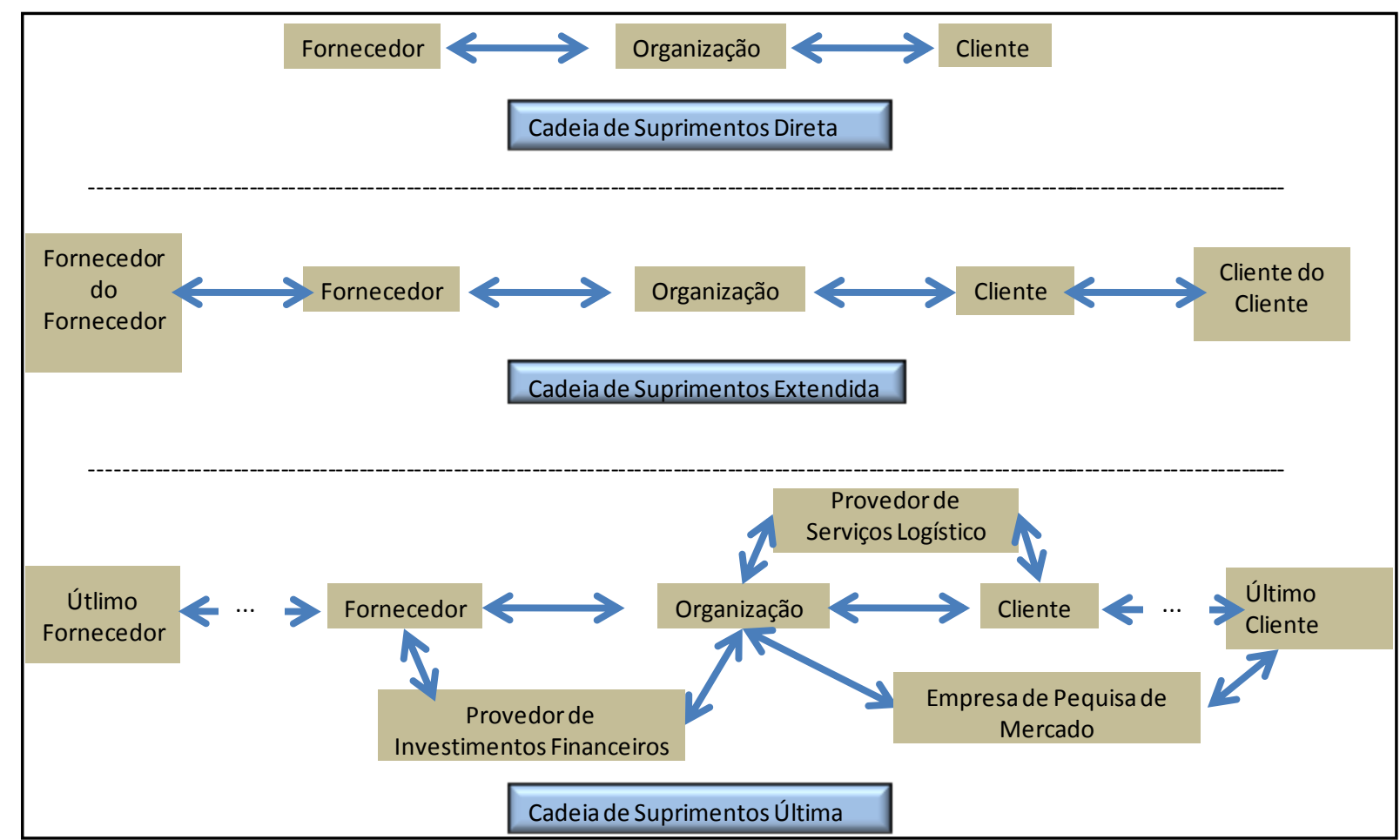

\section{Ilustração 2: Tipos de Canais de Relacionamentos Fonte: Mentzer et al. (2001)}

Beamon (1998) possui outra definição, ele define cadeia de suprimentos como sendo o processo integrado no qual diversas entidades empresariais trabalham em conjunto em um esforço de:

- Compra de materiais.

- Transformarem estas matérias primas em produtos acabados.

- Entregarem estes produtos para revendedores.

De acordo com Chow, Heaver e Henriksson (1994) a cadeia de suprimentos engloba todos os participantes nos processos de transformação, venda e distribuição de produtos desde a matéria-prima até o consumidor final.

Segundo Galaskiewicz (2011) a Cadeia de Suprimentos pode ser muito extensa e englobar diversas nações e diferentes regimes políticos, ele exemplifica isso no caso de uma cadeia de produção de calçados. Galaskiewicz (2011) também afirma que sempre que uma parte da cadeia sofre algum impacto, este pode propagar para outra parte da cadeia. Este autor ainda trabalha com o tema de confiança, se esta falta entre os agentes da cadeia a única opção é se basear em contratos jurídicos e seguros, o que geralmente consome muito tempo e é custoso. 


\subsection{Gestão da Cadeia de Suprimentos}

Esta pesquisa irá analisar uma cadeia de suprimentos, portanto é imprescindível revisar a literatura sobre Gestão da Cadeia de Suprimentos.

A seguir são apresentadas diversas definições sobre Gestão da Cadeia de Suprimentos, pois conforme Janvier-James (2012) afirma, existem numerosas definições.

Alguns autores abordam o tema de SCM com foco no relacionamento externo, além das fronteiras da empresa, ou seja, relacionamentos com outros agentes da cadeia de suprimentos para as diversas atividades, logística, gestão de recursos e gerir fornecedores ou clientes (DYER e SINGH, 1998; DRAKE e SCHLACHTER, 2008).

Kumar e Bharathib (2011) enfatizam o tema da complexidade da cadeia e sua constante mudança, consideram uma grande rede com diversos agentes, fábricas, armazéns, centros de distribuição e varejistas de caráter dinâmico. Estes autores também apontam a necessidade de pesquisas sobre a SCM, uma vez que as cadeias estão em constante alteração, assim é importante entender o momento atual e os possíveis cenários futuros.

Ou et al. (2010) consideram que a SCM é uma ferramenta para manter a estabilidade, crescimento e prosperidade dos negócios, esta impacta diretamente na melhora dos relacionamentos entre fornecedores e clientes. O Conselho dos Profissionais de Gestão da Cadeia de Suprimentos dos Estados Unidos (2009) possui um entendimento diferentemente de Ou et al. (2010), pois afirma que o SCM inclui a concepção e gestão de todas as atividades envolvidas no fornecimento, prospecção, transformação e atividades de gestão logística, com seu principal foco na coordenação e gestão da oferta e da demanda dentro e entre empresas. Wood Jr. e Zuffo (1998) também apresentam o SCM atuando fundamentalmente na coordenação e alinhamento das atividades de produção de forma a reduzir custos e otimizar a operação, maximizando o valor percebido pelo cliente. Os autores Ellram, Tate e Billington (2004) também compartilham este entendimento com foco no controle e gestão, eles consideram não apenas o fluxo de produtos, mas o fluxo de processos, fundos e informações.

Como apresentado acima, diversos autores apresentam distintas definições, alguns focam na coordenação da cadeia, outros nos relacionamentos e outros ainda na complexidade e dinamismo, mas todos consideram a interação entre diversos agentes que trabalham em conjunto.

\subsection{Cadeia de Serviços}

Cadeias de serviços correspondem a um dos tipos de Cadeias de Suprimentos de Serviços. No entanto, existe uma defasagem na literatura referente a esse assunto, como artigos recentes, publicados entre 2011 e 2013, comprovam. Antes, porém, de desenvolver este tema, é importante discutir o conceito e a diferença dos serviços.

Nesta direção, importantes diferenças entre serviços e produtos são levadas em consideração, conforme Akkermans e Voss (2013) apontam: 
- a maioria das Cadeias de Suprimento é representada linearmente, porém as de Serviços frequentemente não são lineares, mas sim são redes, nas quais os fluxos podem ir sentido jusante e montante, segundo Sampson (2012).

- serviços são caracterizados por contato com o cliente; quanto mais essencialmente o serviço, maior o contato com o cliente (Chase, 1978). Sasser (1976) também aponta esta interação cliente-fornecedor e a classifica como uma vantagem mista, pois, por um lado, os consumidores são uma fonte da capacidade de produção, mas, por outro lado, o cliente gera incerteza para os gestores sobre o tempo do processo, a qualidade do produto, e acomodação das necessidades do consumidor.

- diferentemente da perspectiva de produto, na qual o cliente é somente quem recebe o produto, na perspectiva de Serviços, o cliente é um cocriador de valor, juntamente com o fornecedor (VARGO e LUSCH, 2004).

- não é possível estocar serviços para lidar com a variação de demanda (SASSER, 1976). Por este motivo, Giannakis (2011) aponta que serviços podem ser produzidos e consumidos ao mesmo tempo.

Segundo Akkermans e Voss (2013), o conceito de Cadeia de Suprimentos de produtos está muito bem estabelecido, entretanto o conceito de Cadeia de Suprimentos de Serviços ainda está aberto para debates.

Akkermans e Voss (2013) afirmam que algumas definições de Cadeia de Suprimentos de Serviços propostas são baseadas nos modelos de Cadeia de Suprimentos de Produtos, que são visões mais tradicionais dentro da Gestão da Cadeia de Suprimentos. Estes autores citam dois exemplos:

- Ellram et al. (2004) definem a Cadeia de Suprimento de Serviços como "a gestão da informação, processos, capacidade, desempenho e recursos de serviços desde o primeiro fornecedor até o último cliente final";

- Baltacioglu et al. (2007) propõem que a Cadeia de Suprimento de Serviços é a rede de fornecedores, prestadores de serviços, consumidores e outras unidades de apoio que desempenham as funções de transação de recursos necessários para a produção de serviços, transformação desses recursos em apoio e serviços essenciais; e a entrega de serviços a clientes.

Sasser (1976) também aponta que um serviço não pode ser transportado, logo o sistema de entrega deve ser transportado até o cliente ou o cliente deve ser transportado para o sistema pelo qual o serviço é entregue.

Sampson e Froehle (2006) abordam diversas características dos serviços, das quais destaco duas que ainda não foram citadas:

- Perecibilidade: este conceito refere-se à capacidade de operação do fornecedor no tempo, pois uma vez que aquela capacidade de oferecer o serviço, que foi disponibilizada e não foi utilizada, não irá ser recuperada. Por exemplo, a cadeira vazia de um dentista, que precisa que cheguem os dentes do cliente para que o serviço comece. Ou, então, no caso de uma cadeira vazia em um avião comercial, a companhia aérea não poderá colocar este assento disponível em outro avião mais tarde; se ele não for ocupado até o avião decolar, será uma venda perdida. 
- Heterogeneidade: serviços variam de acordo com os recursos dos clientes. Por exemplo, em um restaurante o cliente pode pedir para diminuir o sal na comida, ou seja, alterar o processo. No McDonald's essa variação é restringida pelo cardápio fechado que é oferecido, apesar de ter diversas opções.

Ellram, Tate e Billington (2004) apontam que serviços são geralmente mais difíceis de medir e visualizar; eles também afirmam que, historicamente, os contratos que especificam serviços - como os Acordos de Nível de Serviço (Service Level Agreements - SLA) - não são tão específicos como as especificações de um produto industrial, bem como o desempenho de serviços não é tão fácil de medir quanto as funcionalidades e tolerâncias de um produto. Sasser (1976) também aborda este tema e aponta que, devido à característica intangível das entregas dos serviços, é muito difícil especificar e medir o nível de capacidade de operação e estas medidas acabam se tornando subjetivas e qualitativas.

Tukker (2004) trabalha com o conceito de Sistema Produto Serviço (PSS - ProductService System), que é um conjunto de produtos tangíveis e serviços intangíveis combinados para atender as demandas dos clientes. Este autor desenvolve uma classificação de três tipos de PSS que variam conforme o nível de intangibilidade, ou seja, este autor também se baseia no contínuo de intangibilidade, que varia desde uma classificação de produto puro até serviço puro, conforme ilustração 3.

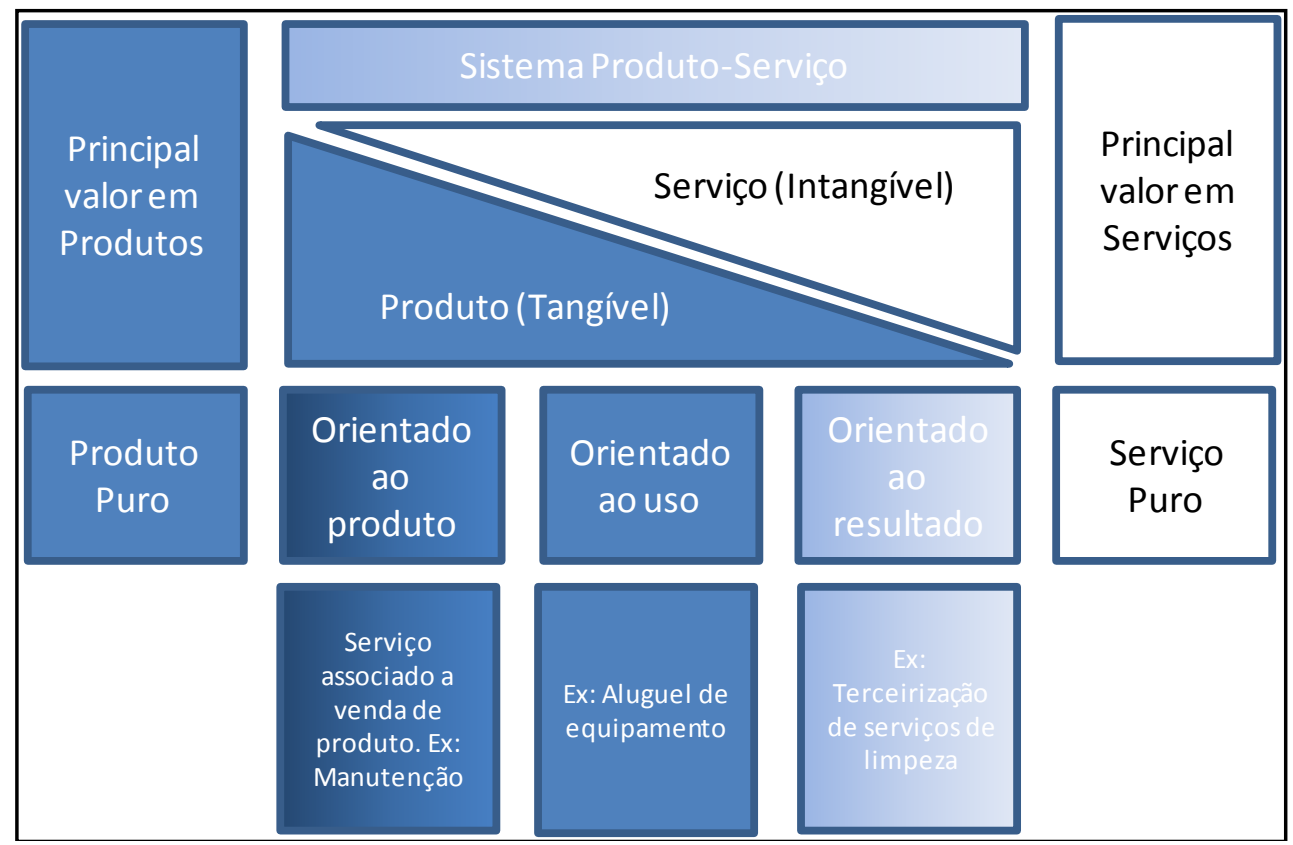

\section{Ilustração 3: Quadro de classificação de Sistemas Produto-Serviços Fonte: Tukker (2004)}

Com base nessas características de serviços, Akkermans e Voss (2013) apontam que, recentemente, acadêmicos oriundos de Gestão de Operações de Serviços começaram a considerar a base da natureza da Cadeia de Suprimentos de Serviços, em oposição ao que os autores de Gestão da Cadeia de Suprimentos haviam desenvolvido, assim considerando diferenças e especificidades de serviços.

Sobre esta nova abordagem, Giannakis (2011) comenta sobre o grande debate nos últimos 30 anos a respeito da utilização de teorias que foram desenvolvidas para Manufatura no contexto de serviços. A perspectiva que existe é que SCM é aplicável somente na produção, uma vez que implica o transporte e gestão de recursos materiais em toda a cadeia 
de abastecimento, ou seja, a perspectiva tradicional de gestão de logística. Entretanto, o pensamento tem evoluído, considerando que os conceitos de áreas como a gestão de fornecedores, terceirização e gestão de compras também podem ser aplicáveis em organizações de serviços.

Akkermans e Voss (2013) seguem nesta direção, baseados nas diversas diferenças entre produtos e serviços, como a não capacidade de estocar serviços, a alta necessidade de interação cliente-fornecedor e a intangibilidade de serviços, as quais já foram citadas no tema Serviços. Ellram et al. (2004) apontam diferenças das cadeias em si. Por exemplo, é fácil encontrar um elo comum nas Cadeias de Suprimentos de Produtos, que é a óbvia gestão de fluxo de produtos físicos; um elo comum assim já é mais complexo de se encontrar nas Cadeias de Suprimento de Serviços. Akkermans e Voss (2013) apontam também uma maior dificuldade de controle da Cadeia de Suprimento de Serviços, pois em serviços é mais difícil de entender como o impacto de uma ação, mesmo que só em uma parte da cadeia, afeta o todo.

Assim, Akkermans e Voss (2013) assumem uma própria definição de Cadeia de Suprimentos de Serviços: "Uma rede de processos de serviços interdependentes a qual engloba entidades de processos múltiplos."

Giannakis (2011) aponta outra diferença das Cadeias de Suprimento de Serviços, o conceito de valor agregado. Este não é facilmente identificável neste tipo de cadeia. Nas cadeias de Suprimento de Produtos, a noção de valor agregado é fácil de conceber, pois está diretamente ligada à transformação da matéria-prima em produtos finais, o que não ocorre em serviços de forma sempre óbvia. O processo de transformação não ocorre da mesma maneira como na indústria; o valor é adicionado por meio da gestão dos fluxos de informação e do conhecimento, durante o processo de interação com os clientes. À medida que os serviços tornam-se mais intangíveis, seja em termos de processo, como em termos de resultado, a gestão de relacionamento com o cliente torna-se mais importante uma vez que o cliente se torna parte do processo de agregação de valor e, portanto, maior ênfase deve ser dada na coordenação de processos relacionais.

Com relação aos relacionamentos da cadeia, Giannakis (2011) destaca a complexidade devido ao necessário trabalho em conjunto dos atores. Semelhante à produção da indústria, a produção de serviços envolve a colaboração de vários atores, como os prestadores de serviços, os prestadores de serviços complementares ao principal ou recursos necessários para o projeto, os responsáveis pela entrega do serviço e os clientes do serviço, todos trabalhando juntos para coproduzir valor em cadeias de valor complexas ou redes. Na ilustração 4 são exemplificados tipos de serviços e sua tangibilidade, inclusive o serviço de transportes é ilustrado como um serviço de saídas tangíveis. 


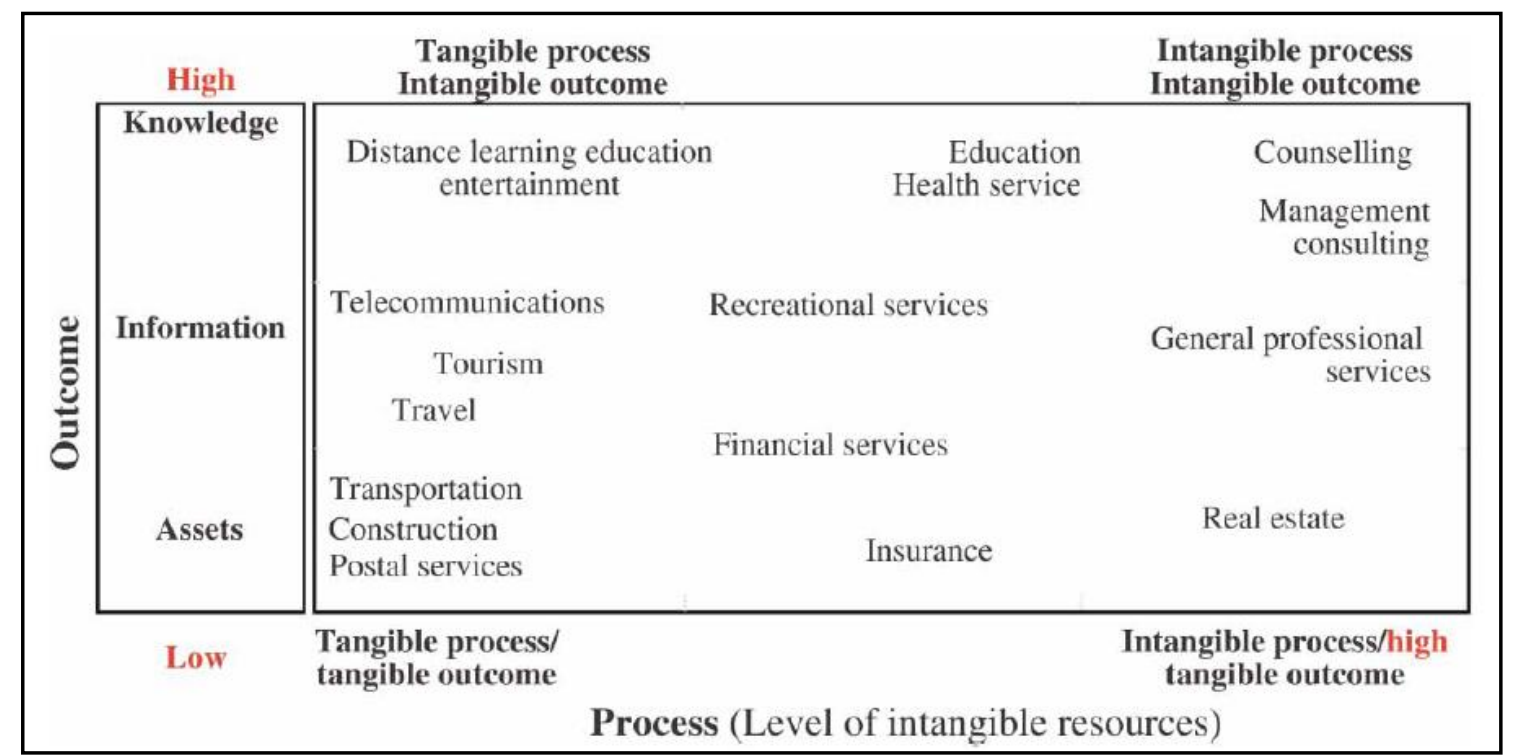

Ilustração 4: Quadro com exemplos de serviços para cada nível de intangibilidade. Fonte: Giannakis (2011) 


\subsection{Ocorrência das Dimensões Estruturais nas Abordagens Atuais}

Este trabalho tem como foco compreender a aplicação das dimensões estruturais da teoria organizacional no contexto da cadeia de suprimentos. Entretanto, diversas pesquisas de Gestão da Cadeia de Suprimentos manifestam estas, mesmo que com outra nomenclatura.

Para analisar a ocorrência destas dimensões, foram levantados 28 artigos que trabalham a análise da cadeia de suprimentos. Estes artigos foram selecionados por meio de buscas feitas no Portal de Busca Integrada da USP, o qual consolida bases renomadas como Ebsco, Proquest, Jstor, WebofScience, Wiley e Emerald. Também foi utilizado o Software "Publish or Perish" (HARZING,2007), o qual encontra os artigos mais citados. Os artigos selecionados, preferencialmente, foram publicados nos principais periódicos de Operações e Cadeia de Suprimentos com base no ranking JCR e na qualificação WebQualis; a lista com os principais se encontram no Anexo I. Na tabela 1, a seguir, todos os artigos selecionados foram agrupados em 12 abordagens da cadeia de suprimentos. Uma descrição mais detalhada por artigo encontra-se no Anexo VII.

Tabela 1: Artigos Agrupados por Abordagem da Cadeia de Suprimentos

\begin{tabular}{|c|c|c|c|c|}
\hline & Método & Propósito & Descrição & Citado / Utilizado por \\
\hline 1 & $\begin{array}{c}\text { Value } \\
\text { Stream } \\
\text { Mapping } \\
\text { VSM - } \\
\text { extended } \\
\text { value } \\
\text { stream } \\
\text { mapping } \\
\text { (EVSM) }\end{array}$ & \multirow{4}{*}{\begin{tabular}{|c|} 
Melhorias \\
operacionais. \\
Exemplo: \\
Aplicação \\
prática. \\
Voltado para \\
gestores que \\
desejam \\
melhorar a \\
eficiência da \\
produção. \\
Origem na \\
metodologia \\
Lean. \\
Redução e \\
eliminação \\
de \\
desperdícios \\
na produção. \\
Oportunida- \\
des de \\
melhorias e \\
apontamento \\
de riscos.
\end{tabular}} & $\begin{array}{l}\text { Foca na análise dos Fluxos de } \\
\text { Materiais e de Informações. } \\
\text { Objetiva avaliar o máximo } \\
\text { possível da cadeia, desde a } \\
\text { matéria prima até o cliente final, } \\
\text { e desenhar o estado futuro }\end{array}$ & $\begin{array}{l}\text { Jones e Womack (2002) } \\
\text { apud Miyake, D. I.; } \\
\text { Torres Jr A. S. e Favaro, } \\
\text { C. (2010) }\end{array}$ \\
\hline 2 & $\begin{array}{l}\text { Value } \\
\text { Stream } \\
\text { Mapping } \\
\text { Tools }\end{array}$ & & $\begin{array}{l}\text { Apresenta } 7 \text { ferramentas; tem o } \\
\text { objetivo de reduzir e eliminar } \\
\text { desperdícios }\end{array}$ & $\begin{array}{l}\text { Brunt D. (2000) } \\
\text { Hines e Rich (1997) apud } \\
\text { Miyake, D. I.; Torres Jr } \\
\text { A. S. e Favaro, C. (2010) }\end{array}$ \\
\hline 3 & $\begin{array}{l}\text { Dynamic } \\
\text { Clockspe } \\
\text { ed } \\
\text { Analysis }\end{array}$ & & $\begin{array}{l}\text { Analisar o Mapa Organizacional } \\
\text { da Cadeia de Suprimentos, o } \\
\text { Mapa Tecnológico da Cadeia de } \\
\text { Suprimentos e o Mapa de } \\
\text { Capacidades do negócio da } \\
\text { Cadeia de Suprimentos } \\
\end{array}$ & $\begin{array}{l}\text { Fine (1998) apud Miyake, } \\
\text { D. I.; Torres Jr A. S. e } \\
\text { Favaro, C. (2010) }\end{array}$ \\
\hline 4 & \begin{tabular}{|} 
Quick \\
Scan \\
Methodol \\
ogy \\
(QSM) \\
\end{tabular} & & $\begin{array}{l}\text { Analisa as incertezas e ataca a } \\
\text { causa raiz relacionada a clientes, } \\
\text { fornecedores, processo de } \\
\text { agregação de valor e controle do } \\
\text { sistema }\end{array}$ & $\begin{array}{l}\text { Towill, Childerhouse e } \\
\text { Disney (2000) apud } \\
\text { Miyake, D. I.; Torres Jr } \\
\text { A. S. e Favaro, C. (2010) }\end{array}$ \\
\hline
\end{tabular}




\begin{tabular}{|c|c|c|c|c|}
\hline 5 & $\begin{array}{l}\text { Supply } \\
\text { Chain } \\
\text { Operation } \\
\text { s } \\
\text { Reference } \\
\text {-model } \\
\text { (SCOR) } \\
\end{array}$ & \multirow{3}{*}{$\begin{array}{c}\text { Integração } \\
\text { da cadeia. } \\
\text { Promover a } \\
\text { comunicação } \\
\text { efetiva entre } \\
\text { os agentes da } \\
\text { rede. } \\
\text { Redução do } \\
\text { ciclo do } \\
\text { pedido }\end{array}$} & $\begin{array}{l}\text { Foca na análise de } 5 \text { atributos de } \\
\text { performance: Confiabilidade, } \\
\text { Responsividade, } \quad \text { Agilidade, } \\
\text { Custos e Utilização de Recursos }\end{array}$ & $\begin{array}{l}\text { Supply Chain Council } \\
\text { (2010); apud Miyake, D. } \\
\text { I.; Torres Jr. A. S. e } \\
\text { Favaro, C. (2010) }\end{array}$ \\
\hline 6 & $\begin{array}{l}\text { Lead time } \\
\text { mapping }\end{array}$ & & $\begin{array}{l}\text { Foca na análise do Controle de } \\
\text { tempos desde o início do pedido } \\
\text { até a Entrega para o cliente. O } \\
\text { tempo é dividido em: } 1 \text { - tempo } \\
\text { de processos (transportes); e } 2 \text { - } \\
\text { tempo parado nos pontos de } \\
\text { entrega da cadeia }\end{array}$ & $\begin{array}{l}\text { Scott e Westbrook (1991) } \\
\text { apud Haartveit, E. Y. ; } \\
\text { Kozak, R. A. e Maness, } \\
\text { T. C. (2004) }\end{array}$ \\
\hline 7 & $\begin{array}{l}\text { SNAP - } \\
\text { supply } \\
\text { network } \\
\text { analysis } \\
\text { process } \\
\text { Tool } \\
\end{array}$ & & $\begin{array}{l}\text { Foca no mapeamento dos } \\
\text { Objetivos da Rede, no } \\
\text { desenvolvimento de um modelo } \\
\text { de tomada de decisão da Rede e } \\
\text { de sua implementação }\end{array}$ & $\begin{array}{l}\text { Yee C. L.; Tan, K. } \\
\text { H.(2004) }\end{array}$ \\
\hline 8 & SONIA & $\begin{array}{l}\text { Entender as } \\
\text { mudanças } \\
\text { estruturais } \\
\text { da cadeia ao } \\
\text { longo do } \\
\text { tempo }\end{array}$ & $\begin{array}{l}\text { Entender as mudanças estruturais } \\
\text { da cadeia ao longo do tempo por } \\
\text { meio de Software disponível em } \\
\text { http://www.stanford.edu/group/so } \\
\text { nia/ }\end{array}$ & $\begin{array}{l}\text { Galaskiewicz, J.(2011) . É } \\
\text { atualmente (2013) } \\
\text { desenvolvido por Dan } \\
\text { McFarland e Skye } \\
\text { Bender-deMoll da } \\
\text { Universidade de Stanford } \\
\text { e disponível em } \\
\text { http://www.stanford.edu/g } \\
\text { roup/sonia/. }\end{array}$ \\
\hline 9 & $\begin{array}{l}\text { Teoria de } \\
\text { Redes e } \\
\text { Social } \\
\text { Network } \\
\text { Analysis } \\
\text { (SNA) }\end{array}$ & $\begin{array}{l}\text { Analisar a } \\
\text { estrutura da } \\
\text { cadeia e o } \\
\text { relaciona- } \\
\text { mento entre } \\
\text { seus agentes }\end{array}$ & $\begin{array}{l}\text { Quase todas as pesquisas de SNA } \\
\text { tentam responder as duas } \\
\text { perguntas: Por que esses agentes } \\
\text { são iguais?; Por que uma agente } \\
\text { tem melhores resultados do que } \\
\text { outros? } 3 \text { teorias básicas são } \\
\text { consideradas neste método: } \\
1 \text { - Teoria da Transmissão } \\
\text { - Grau de centralidade significa } \\
\text { ter mais nós/ligações que se } \\
\text { ligam a ele, quanto mais nós, } \\
\text { mais informação. } \\
\text { - Centralidade e Proximidade - é } \\
\text { o quão perto está o nó, recebe } \\
\text { mais rápida informação. } \\
\text { - Centralidade de intermediária: } \\
\text { os nós que ficam nos principais } \\
\text { caminhos críticos saso } \\
\text { importantes, pois podem } \\
\text { interferir em mudanças nas } \\
\text { informações ou podem ser } \\
\text { gargalos na transmissão de }\end{array}$ & $\begin{array}{l}\text { Choi, T. Y. e Kim, } \\
\text { Y.(2008) } \\
\text { Pollock, T. G.; Porac, J. F. } \\
\text { e Wade, J. B.(2004) } \\
\text { Autry, C.W. e Griffis, } \\
\text { S.E(2008) } \\
\text { Borgatti, S. P. e Li, } \\
\text { X.(2009) } \\
\text { Carter, C. R. e Ellram, L. } \\
\text { M.(2007) } \\
\text { Greve, H. R.(2008 ) } \\
\text { Carter, C. R.; Leuschner, } \\
\text { R. e Rogers, D. S.(2007) } \\
\text { Lee, P. D.(2005) } \\
\text { Kim, Y.; Choi, T. Y.; } \\
\text { Yan, T. e Dooley, } \\
\text { K.(2010) } \\
\text { Galaskiewicz, J.(2011) }\end{array}$ \\
\hline
\end{tabular}




\begin{tabular}{|c|c|c|c|c|}
\hline & & & $\begin{array}{l}\text { informação. } \\
2 \text { - Teoria do Controle } \\
\text { Por exemplo, um fornecedor que } \\
\text { está em contato com vários } \\
\text { outros fornecedores pode se } \\
\text { juntar e ficar mais forte. Deste } \\
\text { ponto de vista, é melhor para o } \\
\text { comprador que o fornecedor } \\
\text { trabalhe isolado. Essa teoria } \\
\text { também leva em consideração a } \\
\text { imagem que os contatos trazem; } \\
\text { posso não ser poderoso, mas se } \\
\text { ando com alguém poderoso. } \\
3 \text { - Teoria da Adaptação } \\
\text { Essa teoria diz respeito a que, se } \\
\text { dois nós tiverem os mesmos tipos } \\
\text { de ligação aos mesmos tipos de } \\
\text { outros nós, eles terão resultados } \\
\text { semelhantes. Eles respondem ao } \\
\text { ambiente }\end{array}$ & \\
\hline 10 & $\begin{array}{c}\text { CAS } \\
\text { Complex } \\
\text { Adaptativ } \\
\text { e Systems }\end{array}$ & $\begin{array}{l}\text { Analisar a } \\
\text { interação } \\
\text { entre cadeia } \\
\text { e ambiente }\end{array}$ & $\begin{array}{l}\text { O CAS trabalha com } 3 \text { conceitos } \\
\text { que se interligam: o sistema; o } \\
\text { ambiente no qual está inserido; e } \\
\text { a coevolução, ou seja, o ambiente } \\
\text { existe independente do sistema, } \\
\text { porém estes evoluem, eles } \\
\text { interagem e se adaptam }\end{array}$ & $\begin{array}{l}\text { Keqiang, W.; Zhaofeng, } \\
\text { Z. e Dongchuan, S.(2008) } \\
\text { Hearnshaw, E. J.S. e } \\
\text { Wilson, M. M. J. (2013) } \\
\text { Pathak, S. D.; Day, J. M.; } \\
\text { Nair, A.; Sawaya, W. J. e } \\
\text { Kristal, M. M.(2007) } \\
\text { Choi, T. Y.; Dooley, K. J. } \\
\text { e Rungtusanatham, } \\
\text { M.(2001) }\end{array}$ \\
\hline 11 & $\begin{array}{l}\text { Supply } \\
\text { Chain } \\
\text { Network } \\
\text { Structure }\end{array}$ & $\begin{array}{l}\text { Entender a } \\
\text { estrutura da } \\
\text { rede, quem } \\
\text { são os } \\
\text { agentes e } \\
\text { quais são as } \\
\text { suas ligações }\end{array}$ & $\begin{array}{l}\text { Foca na análise da Estrutura da } \\
\text { Rede, dos Processos de Negócios } \\
\text { (compras, relacionamento com } \\
\text { clientes e etc.); aponta também } \\
\text { sobre os tipos de links de } \\
\text { processos (os gerenciáveis, não } \\
\text { gerenciáveis, os importantes) e } \\
\text { do Gerenciamento de } \\
\text { componentes (Planejamento e } \\
\text { controle, estrutura de trabalho, } \\
\text { estrutura organizacional, } \\
\text { estrutura de produto, estrutura de } \\
\text { informação, estrutura de poder e } \\
\text { liderança, cultura e atitude) }\end{array}$ & $\begin{array}{l}\text { Min, H. e Zhou, G. (2002) } \\
\text { Cooper, M. C.; Lambert, } \\
\text { D. M. e Pagh, J. D. } \\
\text { (2006) } \\
\text { Lambert, D. M. e Cooper, } \\
\text { M. C. (2000) } \\
\text { Haartveit, E. Y. ; Kozak, } \\
\text { R. A. e Maness, T. C. } \\
\text { (2004) } \\
\text { Miyake, D. I.;Torres Jr A. } \\
\text { S. e Favaro, C. (2010) }\end{array}$ \\
\hline
\end{tabular}




\begin{tabular}{|c|c|c|c|}
\hline 12 & $\begin{array}{l}\text { Diversas } \\
\text { Aborda- } \\
\text { gens }\end{array}$ & $\begin{array}{l}\text { Estes autores não utilizaram } \\
\text { uma abordagem específica, } \\
\text { mas trabalharam com temas } \\
\text { como posicionamento na } \\
\text { cadeia, cooperação e } \\
\text { taxonomia da cadeia }\end{array}$ & $\begin{array}{l}\text { Jarillo, J. C. e Stevenson, H. H. (1991) } \\
\text { Harland, C. M.; Lamming, R. C. e Cousins, } \\
\text { P. D. (1999) } \\
\text { Lamming, R.; Johnsen T.; Zheng J. e Harland } \\
\text { C.(2000) } \\
\text { Gardner, J. T. e Cooper, M. C. (2003) } \\
\text { Zaheer A. e Bell, G. G.(2005) } \\
\text { Harland, C. M.; Lamming, R. C.; Zheng, J. e } \\
\text { Johnsen, T. E.(2001) } \\
\text { Cox, A.; Sanderson, J. e Watson, G.(2001) } \\
\text { Ketchen Jr, D. j.; Tomas G. e Hult, M.(2007) }\end{array}$ \\
\hline
\end{tabular}

Nos artigos analisados, foram identificados vários termos para descrever a estrutura da cadeia. Estes foram agrupados em 4 dimensões na tabela 2, a qual já antecipa a discussão detalhada das dimensões da estrutura organizacional que será feita no item 2.1.7.

Tabela 2: As dimensões da Estrutura Organizacional aparecem nas outras teorias

\begin{tabular}{|c|c|c|c|c|}
\hline Dimensões & Integração & Formalização & Complexidade & \\
\hline $\begin{array}{c}\text { Aspectos } \\
\text { estruturais } \\
\text { identifica- } \\
\text { dos nos } \\
\text { artigos }\end{array}$ & $\begin{array}{l}\text { - Alianças } \\
\text { estratégicas } \\
\text { - Alinhamento de } \\
\text { interesses } \\
\text { - Colaboração } \\
\text { - Compartilhamento } \\
\text { de informações, } \\
\text { recursos e riscos } \\
\text { - Comprometimento } \\
\text { mútuo de longo } \\
\text { prazo } \\
\text { - Confiança } \\
\text { - Cooperação } \\
\text { - Trabalho em } \\
\text { conjunto com } \\
\text { fornecedores } \\
\text { - Integração entre } \\
\text { diversos agentes da } \\
\text { cadeia } \\
\text { - Parceria real } \\
\text { - Relação de longo } \\
\text { prazo } \\
\text { - Relacionamento } \\
\text { próximo a } \\
\text { fornecedores } \\
\text { - Rica comunicação }\end{array}$ & $\begin{array}{l}\text { - Contratos que } \\
\text { asseguram } \\
\text { compartilhamento de } \\
\text { riscos } \\
\text { - Formalização no } \\
\text { relacionamento } \\
\text { - Mecanismos de } \\
\text { coordenação } \\
\text { - Métricas de } \\
\text { avaliação } \\
\text { - Obrigações e } \\
\text { Normas sociais } \\
\text { - Operação segundo } \\
\text { regras } \\
\text { - Políticas para } \\
\text { fornecedores } \\
\text { - Processos estáveis } \\
\text { - Regras de } \\
\text { comportamento } \\
\text { - Regulamentos e } \\
\text { controles } \\
\text { - Rotinas de trabalho } \\
\text { estabelecidas } \\
\text { - Sanções coletivas } \\
\text { - Termos e relações } \\
\text { contratuais }\end{array}$ & $\begin{array}{l}\text { - Cadeia de } \\
\text { Suprimentos } \\
\text { complexa } \\
\text { - Cadeia Longa e } \\
\text { Complexa com } \\
\text { diversos } \\
\text { intermediários } \\
\text { - Complexidade da } \\
\text { Rede } \\
\text { - Complexidade de } \\
\text { cadeias modernas } \\
\text { - Dimensão de } \\
\text { comprimento e } \\
\text { quantidade de } \\
\text { clientes e } \\
\text { fornecedores por } \\
\text { nível } \\
\text { - Dimensão } \\
\text { estrutural vertical e } \\
\text { horizontal } \\
\text { - Estrutura complexa } \\
\text { - Grau de } \\
\text { complexidade } \\
\text { - Interconexões } \\
\text { Complexas } \\
\text { - Redes Complexas }\end{array}$ & $\begin{array}{l}\text { - Centralidade na } \\
\text { rede e no nó } \\
\text { - Centros de poder } \\
\text { - Comportamento } \\
\text { oportunista } \\
\text { - Concentração de } \\
\text { Poder } \\
\text { - Descentralização } \\
\text { - Dominância do } \\
\text { fornecedor ou } \\
\text { comprador } \\
\text { - Empresa focal } \\
\text { - Influência sobre } \\
\text { agentes chaves da } \\
\text { cadeia } \\
\text { - Poder de barganha } \\
\text { - Poder do } \\
\text { intermediário } \\
\text { - Poder no nó central } \\
\text { - Posicionamento na } \\
\text { cadeia } \\
\text { - Relações de poder }\end{array}$ \\
\hline
\end{tabular}

A tabela 3 evidencia a frequência com que as dimensões estruturais da tabela 2 ocorreram nas abordagens da Cadeia de Suprimentos examinadas. Alguns artigos trabalharam com duas abordagens. Nestes casos, o artigo foi considerado uma única vez, para não distorcer a contagem. Porém, como alguns desses artigos eram os únicos representantes de uma abordagem, ao fazer esta correção algumas abordagens ficaram fora da tabela 3. 
Tabela 3: Outras dimensões que possuem relação com as dimensões da Estrutura Organizacional

\begin{tabular}{|c|c|c|c|c|c|c|}
\hline $\begin{array}{l}\text { Abordagens } \\
\text { da Cadeia }\end{array}$ & $\begin{array}{l}\text { Quantidade } \\
\text { de artigos }\end{array}$ & Integração & Formalização & Complexidade & Centralização & TOTAL \\
\hline $\begin{array}{c}\text { Diversas } \\
\text { Abordagens }\end{array}$ & 8 & 7 & 3 & 2 & 3 & 15 \\
\hline $\begin{array}{l}\text { Complex } \\
\text { Adaptative } \\
\text { System }\end{array}$ & 4 & 2 & 3 & 4 & 1 & 10 \\
\hline $\begin{array}{c}\text { Teoria de } \\
\text { Redes e Social } \\
\text { Network } \\
\text { Analysis }\end{array}$ & 10 & 6 & 4 & 4 & 7 & 21 \\
\hline $\begin{array}{c}\text { Supply chain } \\
\text { network } \\
\text { Structure }\end{array}$ & 5 & 5 & 2 & 4 & 2 & 13 \\
\hline SNAP & 1 & 1 & - & - & - & 1 \\
\hline TOTAL & 28 & 21 & 12 & 14 & 13 & \\
\hline
\end{tabular}

No Anexo VIII consta a identificação de cada aspecto da estrutura identificado por artigo.

\subsection{Teoria Organizacional e a Gestão da Cadeia de Suprimentos}

Neste tópico será discutida a associação da teoria organizacional da Gestão da Cadeia de Suprimentos.

Primeiramente, iremos tratar da definição de organização e qual a relação desta com a definição de Cadeia de Suprimentos.

Como é demonstrado na Tabela 4, existem diversas definições de organização:

Tabela 4: Definições de Organização

\begin{tabular}{|c|c|c|}
\hline Autor & Ano & Definição de Organização \\
\hline $\begin{array}{l}\text { Lawrance, P. R.; } \\
\text { Lorsch J. W. }\end{array}$ & 1972 & $\begin{array}{c}\text { Uma organização é a coordenação de diferentes atividades } \\
\text { de contribuintes individuais, com a finalidade de efetuar } \\
\text { transações planejadas com o ambiente }\end{array}$ \\
\hline $\begin{array}{l}\text { Etzioni, A (refere-se a } \\
\text { Talcott Parsons, T. em } \\
\text { Structure and Process } \\
\text { in Modern Societies) }\end{array}$ & 1964 & $\begin{array}{l}\text { As organizações são unidades sociais (ou agrupamentos } \\
\text { humanos) intencionalmente construídas e reconstruídas, a } \\
\text { fim de atingir objetivos específicos. }\end{array}$ \\
\hline Price J. L. & 1972 & Organizações são sistemas sociais com objetivos específicos \\
\hline Robbins S. P. & 1983 & $\begin{array}{l}\text { Uma organização é a coordenação planejada de atividades } \\
\text { coletivas de duas ou mais pessoas, as quais funcionam em } \\
\text { uma base relativamente contínua e por meio da divisão de } \\
\text { trabalho e hierarquia de autoridade, que busca atingir um } \\
\text { objetivo comum ou um conjunto de objetivos }\end{array}$ \\
\hline
\end{tabular}




\begin{tabular}{|c|c|c|}
$\begin{array}{c}\text { Gibson, J. L.; } \\
\text { Ivancevich, J. M.; } \\
\text { Donnelly, J. H. }\end{array}$ & 1991 & $\begin{array}{c}\text { Organizações são entidades que possibilitam que a } \\
\text { sociedade atinja conquistas que não podem ser atingidas por } \\
\text { indivíduos atuando sozinhos }\end{array}$ \\
\hline Jones, G. R. & 2001 & $\begin{array}{c}\text { Organização é uma ferramenta utilizada pelas pessoas para } \\
\text { coordenar as suas ações para obter algo que eles desejem ou } \\
\text { valorizem, ou seja, atingirem seus objetivos. }\end{array}$ \\
\hline
\end{tabular}

Nesta tabela 4 vemos que somente Price (1972) se refere em sua definição explicitamente à organização como um sistema. Entretanto, diversos outros autores colocam em seus livros a perspectiva da organização como sistema.

O teórico Robbins (1983) afirma que existe um grande consenso entre os teóricos organizacionais de que uma perspectiva de sistema proporciona um importante entendimento de como uma organização opera. Um sistema é um arranjo de partes inter-relacionadas e interdependentes de tal forma que produzam um conjunto unificado. Esses sistemas recebem recursos, os transformam e produzem um resultado (ROBBINS, 1983).

Observando outros autores, vemos que podemos encontrar diversas citações que corroboram com Robbins. sistema:

Blau (1977), quando trabalha o tema, a organização social faz menção a esta como um

A concepção da estrutura ou do sistema implica em que as unidades componentes tenham alguma relação entre si e, de acordo com a expressão popular de que "o todo é maior que a soma de suas partes", em que as relações entre as unidades tragam elementos novos à situação. (BLAU, 1977)

Da mesma forma, Lawrance e Lorsch (1972) consideram as organizações como sistemas altamente interdependentes.

Nascimento (2009) aponta que um conceito crítico e objetivo de organização precisa incluir as seguintes sete ideias, entre elas a seguinte: "organizações não são coisas, nem grupos, mas sistemas sociais abertos de processos e inter-relações envolvendo pessoas que produzem resultados."

Conforme citações acima, associar o conceito de organização ao conceito de sistema de forma explícita é uma abordagem aceita por renomados acadêmicos. Assim, se for examinado, por exemplo, a definição de sistemas de Daft (2005) - o qual define um sistema como um conjunto de partes inter-relacionadas que funcionam como um todo para alcançar um propósito comum - é fácil identificar semelhanças aos conceitos de organização. Por exemplo, organização também é um conjunto de entidades, sistemas sociais ou unidades sociais que buscam coordenar atividades para atingir objetivos comuns. Podemos encontrar esses conceitos, por exemplo, nas definições de Etzioni (1964), Robbins (1983), Gibson, Ivancevich e Donnelly (1991).

Uma vez que a associação de organização com sistemas é clara, também é possível enxergar facilmente a associação destes conceitos com a Cadeia de Suprimentos. Segundo Mentzer et al. (2001), a Cadeia de Suprimentos é um conjunto de três ou mais entidades (organizações ou indivíduos) diretamente envolvidos no fluxo jusante ou montante de produtos, serviços, finanças, e/ou informações de uma origem para o cliente. 
Da definição de Cadeia de Suprimentos de Mentzer et al. (2001) é possível associar o que estes autores chamam de entidades ao conjunto de partes inter-relacionadas citadas por Daft (2005) ou ainda às unidades sociais citadas por Etzioni (1964). Também fica clara a associação das atividades que promovem o fluxo de produtos e serviços, como o objetivo comum citado por Robbins (1983) e Eztioni (1964).

Com base nessa relação entre Organização, Sistema e Cadeia de Suprimentos, existem diversos autores que propõe que as teorias organizacionais sejam utilizadas para o estudo da Gestão da Cadeia de Suprimentos.

Ketchen e Hult (2006) é um exemplo de trabalho que promoveu uma perspectiva da Teoria Organizacional para a Gestão de Cadeias de Suprimentos. Estes autores trabalham com o conceito de Cadeia de Melhor Valor (Best Value Chain), cadeias responsáveis pela melhoria de resultados chaves que irão direcionar o resultado da empresa e que também agregam valor à empresa. Neste trabalho, Ketchen e Hult utilizam nove teorias organizacionais chave para diferenciar as Cadeias de Suprimentos tradicionais das Cadeias de Melhor Valor.

Ketchen e Hult (2011), revisitando este tema, afirmam que este encontro de teorias organizacionais na pesquisa da Cadeia de Suprimentos proporciona uma boa teoria que ambos, acadêmicos e organizações, poderão tirar proveito.

Miles e Snow (2007), sobre a utilização de teoria organizacional no estudo de Cadeias de Suprimentos, comentam: "no geral, esta avaliação vai mostrar que a pesquisa da cadeia de suprimentos, que originalmente focou estritamente na movimentação eficiente de mercadorias entre empresas dentro de uma indústria, agora incorpora uma quantidade substancial de teoria organizacional." (MILES e SNOW, 2007). Neste artigo, Miles e Snow trabalham com diversas teorias organizacionais e citam outros diversos teóricos que seguem esta mesma orientação.

Ketchen e Hult (2006) fazem um chamado à necessidade de integrar as teorias:

\footnotetext{
"Teorias Organizacionais têm o potencial de oferecer sabedoria provocativa e útil para o campo da Gestão da Cadeia de Suprimentos, mas o potencial das Teorias Organizacionais se manteve praticamente subdesenvolvido na área de Cadeia de Suprimentos. Como resultado, existem enormes oportunidades para integrar conhecimentos de Teoria Organizacional e Gestão da Cadeia de Suprimentos, a fim de construir a compreensão de por que algumas cadeias de suprimentos superam outras." (KETCHEN e HULT, 2006)
}

Choi e Hong (2002) utilizam a Perspectiva da Análise de Estrutura Organizacional para analisar e mapear uma cadeia de suprimentos do setor automotivo. Em contato com o Thomas Choi por e-mail, em outubro de 2013, este autor sugere que esta perspectiva pode sempre ser usada se o objetivo for entender o comportamento e a operação da Cadeia em questão, seja de serviços ou manufatura.

Desta forma, considerando que a utilização de Teorias Organizacionais para a Cadeia de Suprimentos pode criar grande valor teórico, conforme Choi e Hong (2002) demonstraram utilizando a Perspectiva da Análise de Estrutura Organizacional, e também observando que a Perspectiva da Análise de Estrutura Organizacional é um método coerente para se compreender o comportamento e operação da Cadeia de Suprimentos, será utilizada neste projeto a teoria de Estrutura Organizacional, a qual será analisada com profundidade no próximo tema. 


\subsection{Estrutura Organizacional}

Uma vez que este projeto irá utilizar a Perspectiva da Análise de Estrutura Organizacional, conforme justificado nos capítulos acima, é essencial que seja feita a revisão da literatura sobre esta teoria, que se encontra a seguir.

Segundo Jones (2001), a Estrutura Organizacional é um sistema formal de atividades e relacionamentos de autoridade, os quais controlam como as pessoas coordenam suas atividades e seus recursos para atingir objetivos organizacionais. Jones (2001) complementa que a principal função da Estrutura Organizacional é o controle sobre a forma como as pessoas coordenam suas ações para atingir os objetivos organizacionais e sobre os meios para motivar as pessoas para atingirem esses objetivos. Este autor ainda aponta a evolução que a estrutura pode sofrer de acordo com o crescimento e diferenciação que a empresa sofre. Jones (2001) diferencia o Desenho Organizacional da Estrutura, sendo o Desenho o processo pelo qual se faz a gestão e a mudança da Estrutura Organizacional.

Segundo Gibson, Ivancevich e Donnelly (1991), Estrutura Organizacional é um conceito abstrato, por isso o que podemos observar são suas evidências, então inferimos que existe esta está presente. Estes autores também a descrevem como uma forma de controle e influência no comportamento dos indivíduos. Esta também deve estar de acordo com os propósitos e objetivos da organização, bem como afeta o comportamento de indivíduos e grupos. Por exemplo, por meio da Estrutura são definidos as posições e departamentos que ficarão mais próximos ou não.

Para Robbins (1983), a estrutura é composta de três componentes: complexidade, formalização e centralização.

Daft (2005) considera que, na Estrutura Organizacional, a Organização define como as tarefas serão divididas, os recursos são distribuídos e os departamentos são coordenados.

De todas estas definições, podemos concluir que a Estrutura Organizacional é uma forma de controle e organização das pessoas, atividades e grupos e esta conta com hierarquia e diferenciação do trabalho.

\subsection{Desenho da Estrutura Organizacional}

Jones (2001) define o Desenho Organizacional como o processo pelo qual os gestores selecionam e gerenciam aspectos da estrutura e da cultura organizacional, de tal forma que uma organização possa controlar as atividades necessárias para atingir seus objetivos. $\mathrm{O}$ autor exemplifica com as decisões que os gestores devem tomar com relação às pressões internas e externas à organização como, por exemplo, decidir entre uma estrutura que foque no corte de custos de produção ao invés de uma estrutura que promova a flexibilidade.

Gibson, Ivancevich e Donnelly (1991) definem Desenho Organizacional como ações e decisões gerenciais, explícitas ou não, que resultaram em uma específica Estrutura Organizacional. Estes autores consideram que as decisões são quatro: 
- Divisão do Trabalho: é o processo de dividir o trabalho em processos relativamente específicos para atingir vantagens da especialização. A divisão pode ser feita, por exemplo, por habilidade pessoal ou por etapa do processo.

- Departamentalização: é o processo no qual a organização é dividida estruturalmente pela combinação de trabalhos em departamentos, de acordo com características compartilhadas. Alguns exemplos são a departamentalização por função, região ou produto.

- Amplitude de Controle: é o número de indivíduos que reportam diretamente para um gestor.

- Delegação de Autoridade: é o processo de distribuir autoridade entre os níveis mais baixos da hierarquia. Maior delegação pode promover nos gestores uma maior motivação, devido à influência na solução de problemas.

Robbins (1983) considera que o Desenho Organizacional diz respeito à construção e mudanças na estrutura organizacional, para que os objetivos da organização sejam atingidos.

Nem todos os autores diferenciam o conceito de Desenho Organizacional do conceito de Estrutura Organizacional. Mas todos os autores que o fazem, citados acima, concordam que Desenho Organizacional são decisões gerenciais às quais irão impactar e definir qual será a Estrutura Organizacional, conforme ilustração 5.

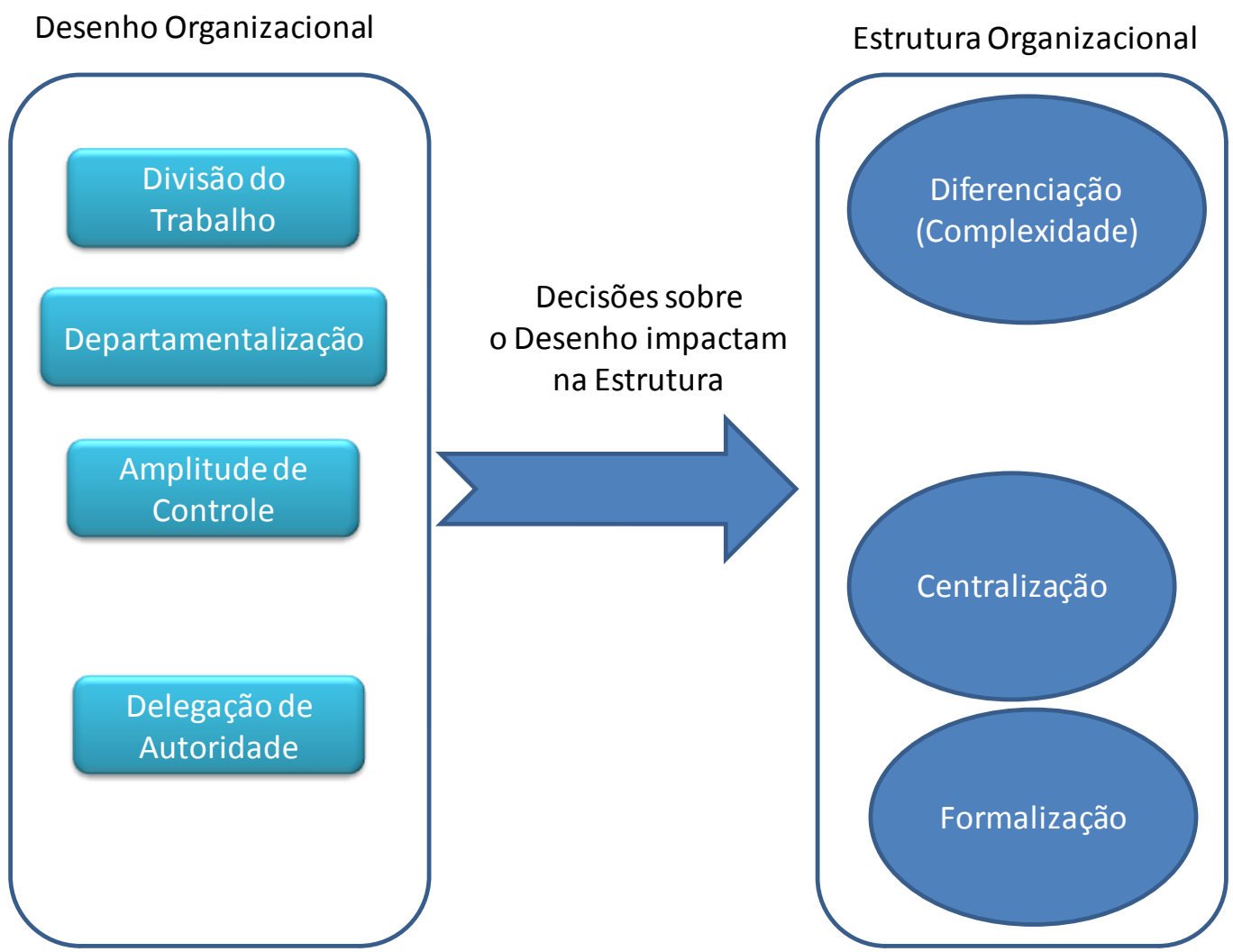

Ilustração 5: Divisão dos conceitos de Desenho Organizacional e Estrutura Fonte: O autor baseado nos conceitos de Gibson, Ivancevich e Donnelly (1991) 


\subsection{Dimensões da Estrutura Organizacional}

Gibson, Ivancevich e Donnelly (1991) afirmam que um consenso universal do conjunto de dimensões não é possível nem desejável, porém atualmente três dimensões são utilizadas na pesquisa e literatura: formalização, centralização e complexidade.

Vemos que os diversos autores de Estrutura Organizacional trabalham com diferentes classificações. Jones (2001) não considera as dimensões específicas da estrutura organizacional, porém discute a formalização, complexidade e centralização nos itens relacionados ao Desenho Organizacional.

Apesar de não haver um consenso entre os autores, Gibson, Ivancevich e Donnelly (1991), Robbins (1983) e Hall (1982) e Choi e Hong (2002) consideram que a Estrutura Organizacional pode ser capturada em três dimensões: formalidade, complexidade e centralização.

Alguns autores não fazem diferenciação entre quais são os elementos de tomada de decisão dentro do Desenho Organizacional e quais são os elementos da Estrutura Organizacional. Por exemplo, Jones (2001) aborda diversos temas dentro de Desenho Organizacional e é possível relacionar todos estes temas diretamente às três dimensões: formalização, centralização e complexidade.

Apesar de uma grande parte dos autores trabalharem essencialmente essas três dimensões, diferentes autores propõem ainda algumas outras. Uma delas é a Integração. Adicionalmente às outras três dimensões, a Integração será avaliada nesta pesquisa, pois como a tabela 3 já evidenciou, esta é uma dimensão de destaque para a Cadeia de Suprimentos, conforme a literatura aponta.

Tabela 5: Dimensões da Análise de Estrutura Organizacional utilizadas para o Estudo da Cadeia de Suprimentos

\begin{tabular}{|c|c|c|c|c|c|c|}
\hline Dimensões & Descrição & \multicolumn{5}{|c|}{ Autores que tratam destas dimensões } \\
\hline Centralização & $\begin{array}{l}\text { Relativo à concentração de } \\
\text { poder e tomada de decisão } \\
\text { em um nível da alta gestão. } \\
\text { (ROBBINS, 1983) } \\
\text { (GIBSON, IVANCEVICH E } \\
\text { DONNELLY ,1991) } \\
\text { (PRICE, 1972) }\end{array}$ & $\begin{array}{c}\text { Robbins } \\
\text { (1983) }\end{array}$ & $\begin{array}{l}\text { Price } \\
(1972 \\
\quad)\end{array}$ & $\begin{array}{l}\text { Hall } \\
(1982 \\
\quad)\end{array}$ & $\begin{array}{l}\text { Gibson, } \\
\text { Ivancevic } \\
\text { h e } \\
\text { Donnelly } \\
(1991)\end{array}$ & $\begin{array}{l}\text { Jones } \\
(2001 \\
\quad)\end{array}$ \\
\hline Complexidade & $\begin{array}{l}\text { Diferenciação Vertical, } \\
\text { Horizontal e Dispersão } \\
\text { Espacial. (ROBBINS, 1983) } \\
\text { (PRICE, 1972) }\end{array}$ & $\begin{array}{c}\text { Robbins } \\
\text { (1983) }\end{array}$ & $\begin{array}{l}\text { Price } \\
(1972 \\
\quad)\end{array}$ & $\begin{array}{l}\text { Hall } \\
(1982 \\
\quad)\end{array}$ & $\begin{array}{l}\text { Gibson, } \\
\text { Ivancevic } \\
\text { h e } \\
\text { Donnelly } \\
(1991) \\
\end{array}$ & $\begin{array}{l}\text { Jones } \\
(2001 \\
\quad)\end{array}$ \\
\hline Formalização & $\begin{array}{l}\text { Relativo ao nível de regras } \\
\text { explícitas.(GIBSON, } \\
\text { IVANCEVICH E } \\
\text { DONNELLY,1991) e } \\
\text { (PRICE, 1972) }\end{array}$ & $\begin{array}{c}\text { Robbins } \\
\text { (1983) }\end{array}$ & $\begin{array}{l}\text { Price } \\
(1972 \\
\quad)\end{array}$ & $\begin{array}{l}\text { Hall } \\
(1982 \\
\quad)\end{array}$ & $\begin{array}{l}\text { Gibson, } \\
\text { Ivancevic } \\
\text { h e } \\
\text { Donnelly } \\
\text { (1991) }\end{array}$ & $\begin{array}{l}\text { Jones } \\
(2001 \\
\quad)\end{array}$ \\
\hline
\end{tabular}




\begin{tabular}{|c|c|c|c|c|c|}
\hline Integração & $\begin{array}{l}\text { É qualidade de colaboração } \\
\text { entre os departamentos para } \\
\text { que estes trabalhem em } \\
\text { conjunto e atinjam um único } \\
\text { conjunto de esforços entre } \\
\text { unidades organizacionais. } \\
\text { (ROBBINS, 1983) }\end{array}$ & $\begin{array}{c}\text { Robbins } \\
\text { (1983) }\end{array}$ & - & - & $\begin{array}{c}\text { Jones } \\
(2001 \\
)\end{array}$ \\
\hline
\end{tabular}

A seguir, essas quatro dimensões serão discutidas com mais detalhes.

\subsection{Dimensão: Formalização}

Segundo Gibson, Ivancevich e Donnelly (1991), a Formalização está relacionada a quanto os objetivos e os meios de trabalho estão especificados e claramente escritos. Estruturas Organizações altamente formalizadas possuem regras e procedimentos disponíveis para direcionar o que cada indivíduo deve fazer. Essas organizações possuem procedimentos operacionais, diretivas e políticas explícitas.

Gibson, Ivancevich e Donnelly (1991) ainda relacionam à alta formalização a alta divisão do trabalho, a grande delegação de autoridade, departamentalização funcional e grande amplitude de controle.

Desenho Organizacional

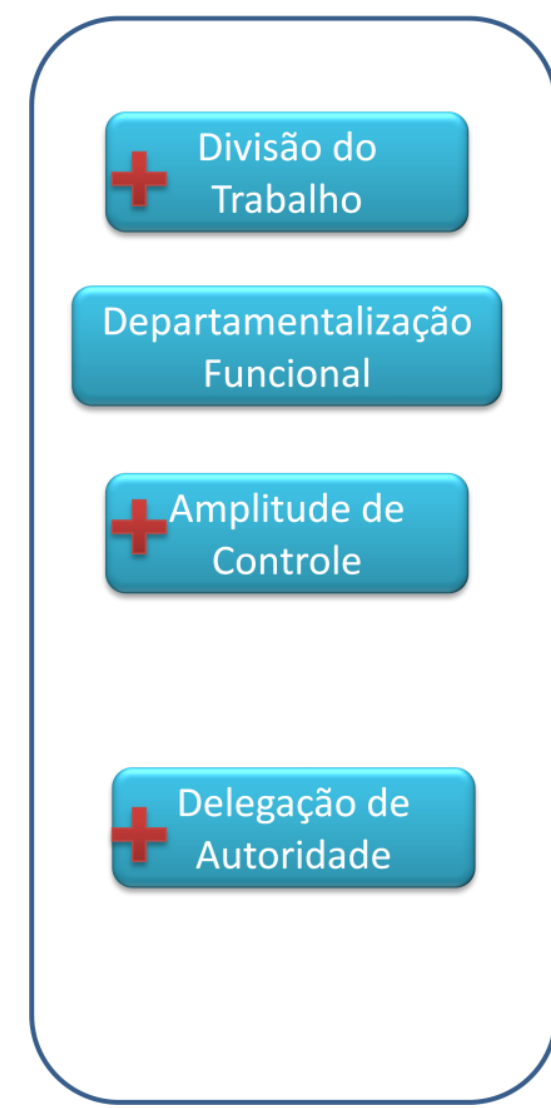

Estrutura Organizacional

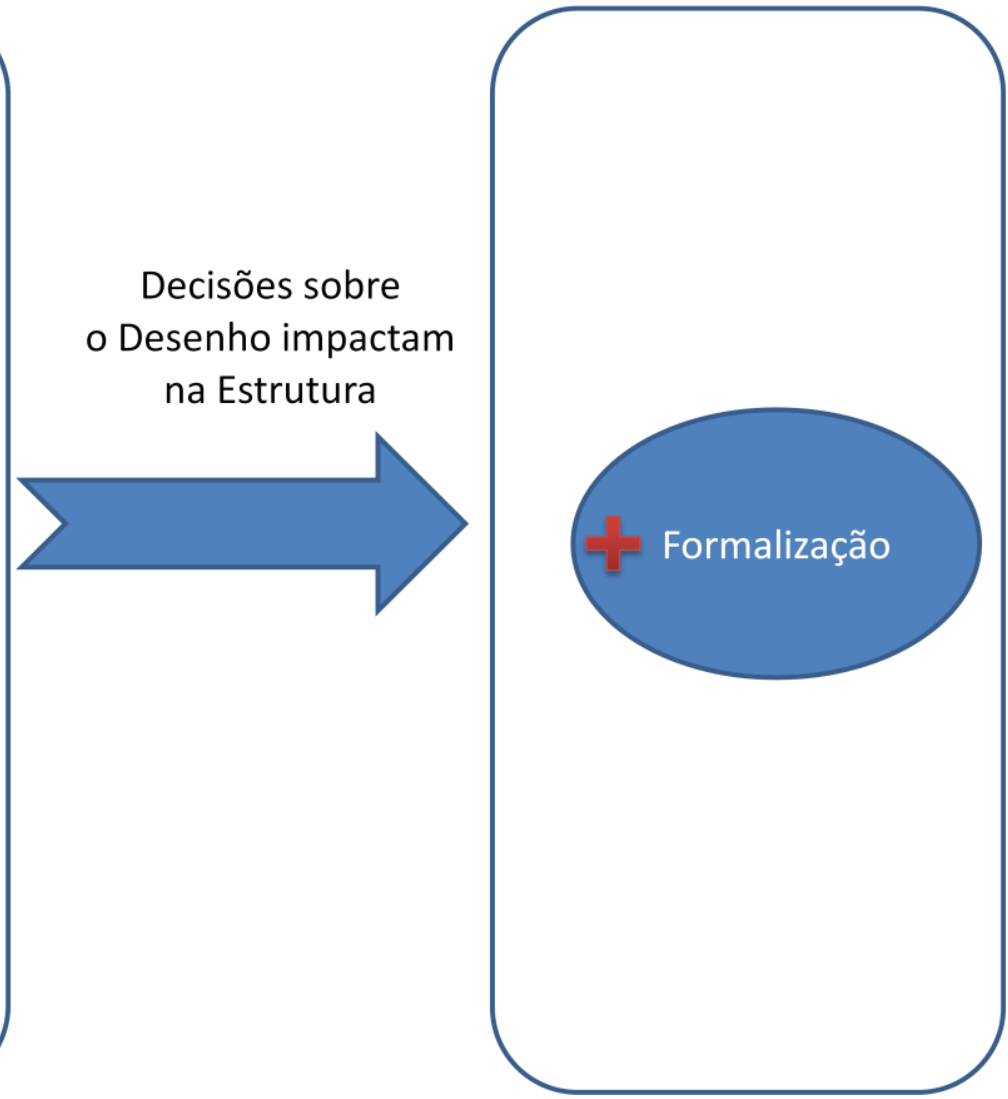

Ilustração 6: Decisões do Desenho Organizacional que causam alta formalização Fonte: $O$ autor baseado nos conceitos de Gibson, Ivancevich e Donnelly (1991) 
A Ilustração 6 mostra as seguintes relações das Decisões Organizacionais na Formalização:

- Uma maior divisão do trabalho e uma departamentalização Funcional levam a uma especialização do trabalho que justifica procedimentos mais específicos e que direcionem melhor as atividades.

- A alta amplitude de controle dificulta que a gestão próxima, gestão de um a um; assim, é necessário que existam regras escritas.

- Da mesma forma, a grande delegação de autoridade exige maior controle, o que necessita de claros controles escritos.

Gibson, Ivancevich e Donnelly (1991) ainda pedem atenção àquelas organizações que possuem todas as características de uma organização formal, com regras e procedimentos explícitos e claros, porém estes não são considerados pelos trabalhadores. Neste caso, é necessário reforçar a utilização dos procedimentos, se este for o objetivo de se explicitar as regras.

Considerando estas empresas que possuem regras explícitas - as Organizações Formais -, Blau (1977) ressalta que é impossível que todas as atividades sejam coordenadas pelas regras definidas, por mais que a gestão se esforce no planejamento destas atividades. Assim, Blau (1977) considera que as atividades informais fazem parte da organização, entretanto as regras e procedimentos oficiais devem ter alcance para poderem cobrir a multidão de situações que possam aparecer. Mas, para casos muito específicos, essas aplicações podem trazer problemas, assim novos hábitos irão surgir para solucionar estes casos específicos.

Hall (1982) apresenta os dois extremos no continuum da formalização:

- Formalização máxima: diante de diversas contingências, a empresa conseguiu se preparar para dar as mesmas respostas ou agir sempre de acordo com o procedimento. Hall (1982) dá o exemplo de um trabalhador na linha de produção sempre executando o mesmo trabalho, na mesma direção da mesma forma; também é citado o computador que irá responder sempre da mesma forma, como foi programado.

- Formalização mínima: Não existem procedimentos, os trabalhadores devem sempre procurar seu próprio critério para decidirem o que irão fazer. Um exemplo deste tipo de estrutura: organização que está na área de pesquisa científica, pois lidam diariamente com situações não previstas e cujos resultados são desconhecidos.

Hall (1982) ainda relaciona à formalização a capacidade de tomada de decisões dos trabalhadores. Teoricamente, aqueles com mais experiência e qualificação poderiam ter melhor capacidade de julgamento e, assim, a necessidade de formalização seria menor. Isso mostra a complexidade das organizações, pois fazer correlações entre formalização e centralização ou descentralização inclui a consideração de novas variáveis, como a qualificação dos trabalhadores. Hall (1982) aponta que a relação de alta formalização com baixa inovação também não pode ser facilmente aceita, pois existem pesquisas contraditórias a esta ideia.

Para Price (1972), a Formalização diz respeito a quão explícitas estão as regras de um sistema social. Este autor também discute a necessidade dessas regras estarem escritas. 
Embora geralmente uma empresa com mais regras escritas tenda a ser mais formalizada, não necessariamente uma que não possua regras escritas pode ser considerada não formalizada. Assim, Price (1972) esclarece que as regras podem ser muito explícitas sem estarem escritas, por isso restringir a análise da formalização às regras escritas é um erro.

Robbins (1983) define Formalização como o grau de padronização que os trabalhos dentro da organização possuem. Segundo este autor, se o um indivíduo possui pouca liberdade/autonomia para decidir o que fazer e como fazer, ele está em uma organização com alto nível de formalização. Quanto mais complexa a atividade, menos suscetível ela é à alta formalização, as atividades mais simples são fáceis de serem controladas e formalizadas. Robbins (1983) também trabalha o conceito de formalização interna, quando o funcionário já entra na empresa com uma série de comportamentos e valores padrões que já são esperados que ele os tenha no trabalho; e, também, com o conceito de formalização externa, quando é imposta pela empresa. Este autor ainda discute os processos de seleção, treinamento e outras técnicas de formalização, como os rituais, a fim de conseguir que os funcionários sigam as regras e procedimentos.

A discussão em torno do conceito de Formalização é grande, entretanto existe um consenso dos autores sobre o tema: todos consideram que este está relacionado à explicitação das regras e procedimentos, sejam estas escritas ou não.

\subsection{Dimensão: Centralização}

Segundo Gibson, Ivancevich e Donnelly (1991), a Centralização se refere à forma como a tomada de decisões é alocada na hierarquia da organização, ou seja, como é feita a delegação de autoridade entre as funções dentro da organização. Estes autores destacam que este conceito geralmente está associado ao controle e à tomada de decisão.

Gibson, Ivancevich e Donnelly (1991) consideram que este conceito pode ser complexo, devido a três fatores:

- Pessoas que estão em um mesmo nível dentro da hierarquia podem ter autonomias diferentes para tomada de decisão.

- Nem todas as tomadas de decisões são de igual importância e impacto. Assim, um gestor pode delegar questões mais operacionais, porém centraliza as decisões estratégicas.

- Nem sempre a autoridade que foi definida oficialmente ocorre na prática; pode ocorrer que um trabalhador que possua na descrição de seu cargo autoridade, na prática não tenha essa autoridade. 


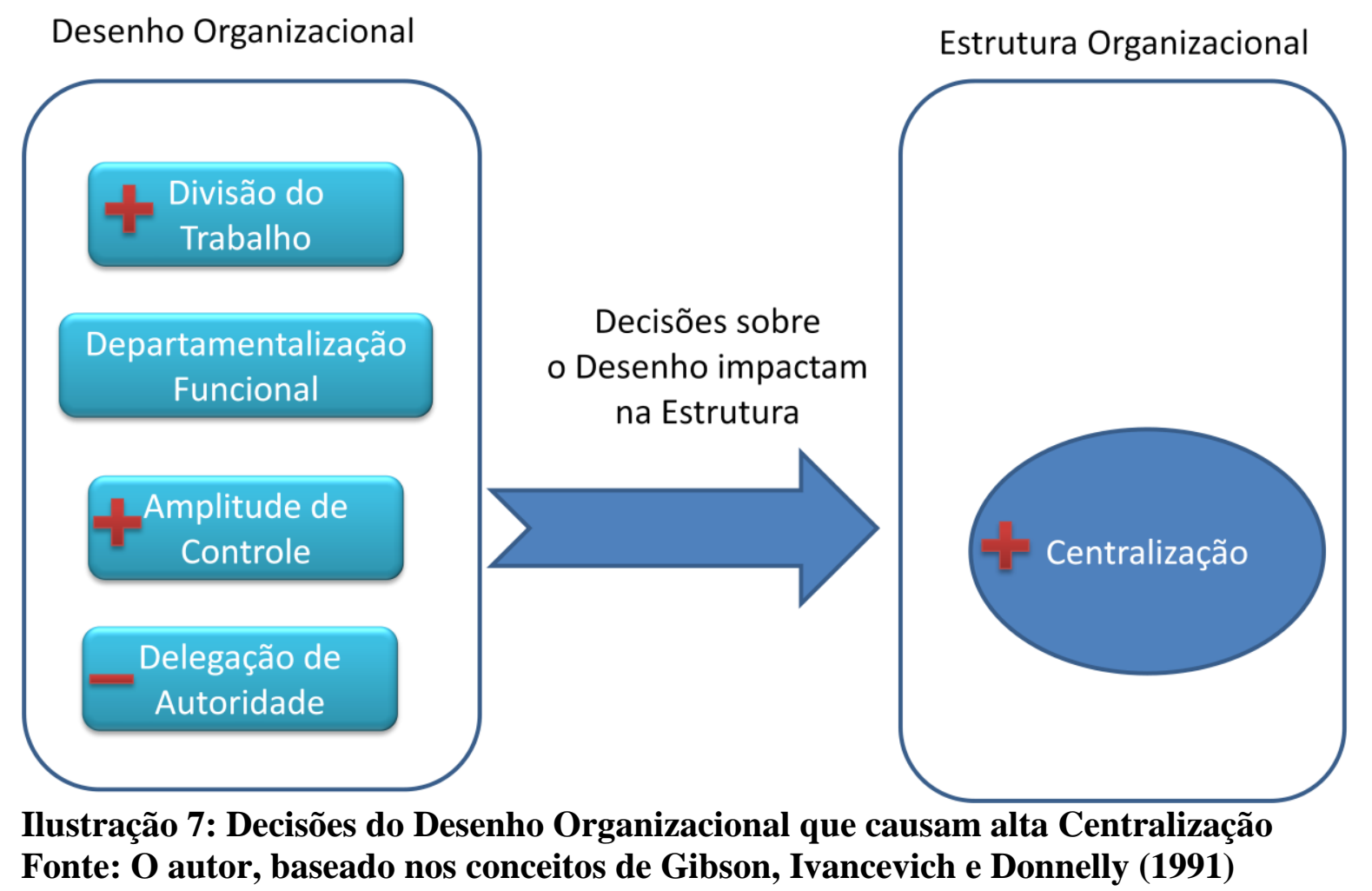

A Ilustração 7 mostra as seguintes relações das Decisões Organizacionais na Centralização:

- A maior divisão do trabalho não exige tomada de decisão, pois as funções são muito bem definidas.

- Quanto mais funcional a departamentalização, maior a necessidade de controle entre as áreas, assim maior a centralização.

- Por definição, quanto menos delegação, maior centralização.

- Quanto maior a amplitude de controle, as atividades são mais especializadas, demandando menor tomada de decisão.

Segundo Hall (1982), quando a maior parte das decisões ocorre no topo da organização, ela pode ser considerada centralizada. Este autor ainda considera que uma importante variável para se considerar é a formalização, quantas regras e políticas estão definidas. Pois, apesar de uma empresa ser centralizada, se esta também for altamente formalizada, as decisões que estão concentradas ainda assim estarão seguindo procedimentos já pré-estabelecidos e os problemas que estiverem fora do escopo dos procedimentos deverão ser escalados para um nível superior. Ver ilustração 8. 
Centralização em relação a formalização.

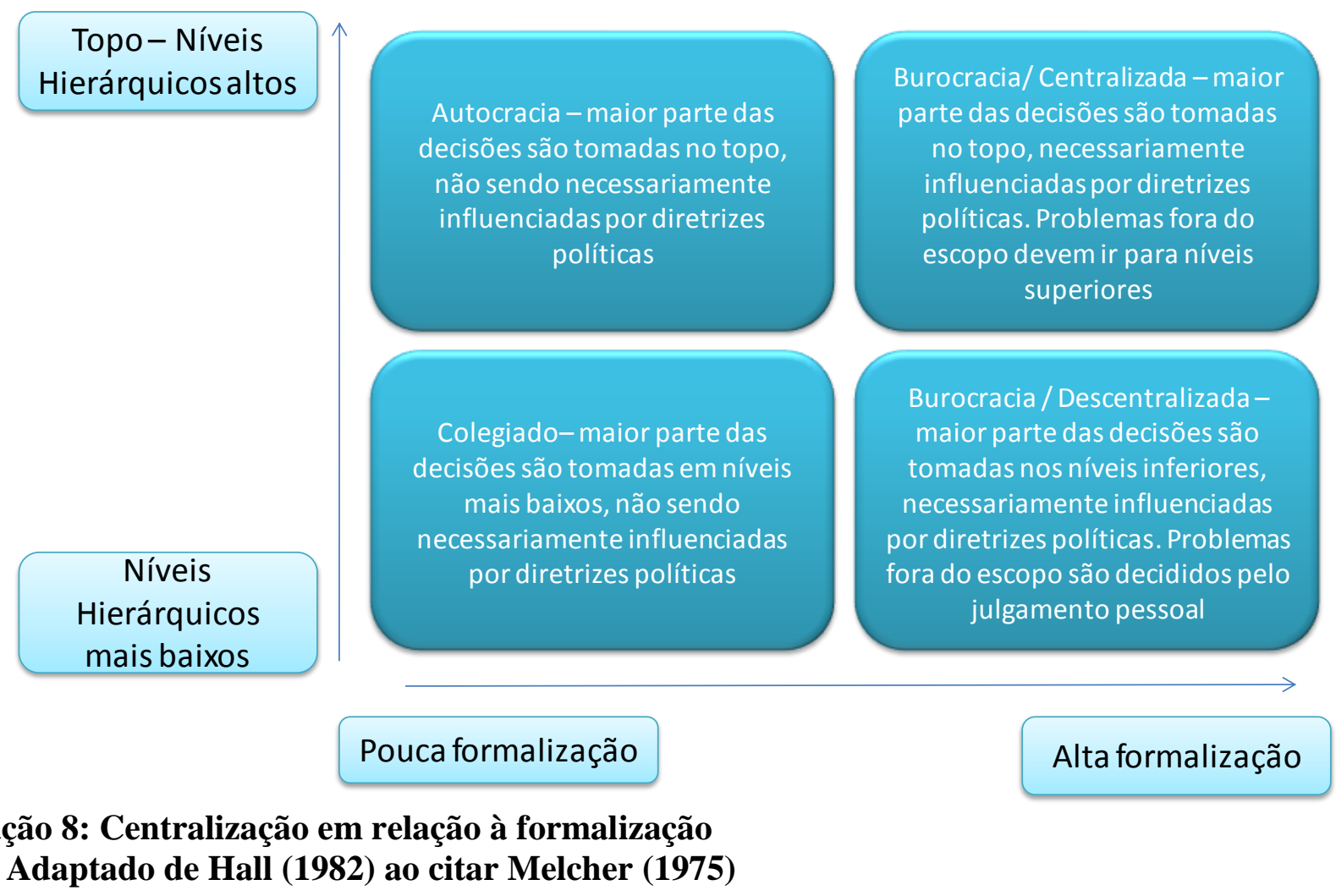

Hall (1982) discute ainda a questão da influência do ambiente, pois quando uma empresa está inserida em um grupo de empresas que são altamente centralizadas, é possível que esta também seja. Isso também demonstra a visão que a empresa possui de seus funcionários, pois uma vez que a empresa é altamente centralizada, entende que seus trabalhadores precisam de um alto controle e não possuem capacidade de tomada de decisão.

Robbins (1983) aponta que, das três dimensões, esta é a mais complexa, por isso define Centralização como o grau em que a autoridade formal, para tomar decisões é concentrada em um indivíduo, unidade ou nível (geralmente na alta gestão), assim permitindo o mínimo de interferência dos empregados em seu trabalho (geralmente na baixa gestão). Robbins (1983) faz algumas observações sobre a centralização:

- Centralização diz respeito somente ao poder formal; o poder informal que sempre está presente não é considerado pelo conceito.

- Caso haja delegação de autoridade, mas haja uma extensiva política de procedimentos que restrinjam a tomada de decisão, embora pareça descentralizada, a organização é centralizada.

- A concentração de poder em um ponto significa uma pessoa ou uma unidade ou um nível, mas precisa ser na alta gestão.

- Mesmo que haja um sistema de controle forte, para que a alta gestão saiba quais decisões foram tomadas, isso não implica em centralização, pois quem está tomando as decisões ainda são média e baixa gestão.

- As informações utilizadas pela alta gestão podem vir dos níveis operacionais; conforme essa informação sobe de nível, ela é filtrada; esse filtro é uma forma de descentralização. 
Robbins (1983) ainda destaca o conceito de autoridade, o qual é definido como direito de atuar ou comandar os outros a atuar em direção aos objetivos organizacionais. Este é um direito associado à posição ou cargo e não à pessoa. Robbins (1983) aponta que a descentralização pode gerar motivação nos funcionários e também pode servir de treinamento.

Robbins (1983) aponta cuidado ao associar Centralização a Formalização, pois uma organização altamente formalizada pode ser tanto altamente centralizada quanto altamente descentralizada. Com relação à associação de Centralização e Complexidade, Robbins (1983) aponta que, quanto mais complexa, mais descentralizada, uma atividade mais simples requer menos treinamento e pode ser mais Centralizada.

Price (1972) define que Centralização é o grau de concentração de poder em um sistema social. Se um único indivíduo concentra todo o poder de uma organização, então esta pode ser considerada com o máximo grau de centralização.

Todos os autores concordam que o conceito de Centralização diz respeito à concentração de poder na tomada de decisão em um nível hierárquico, geralmente na alta gestão.

\subsection{Dimensão: Complexidade}

Gibson, Ivancevich e Donnelly (1991) definem a Complexidade como o resultado da divisão do trabalho e da criação de departamentos. É o número de diferentes posições de trabalho e níveis de autoridade dentro da organização. Mais especificamente, é o número de grupos de ocupações ou número das distintas unidades ou departamentos dentro da organização. Assim, uma empresa será mais complexa de se gerenciar se tiver um número maior de divisões. Os termos diferenciação vertical e horizontal são diretamente relacionados à complexidade.

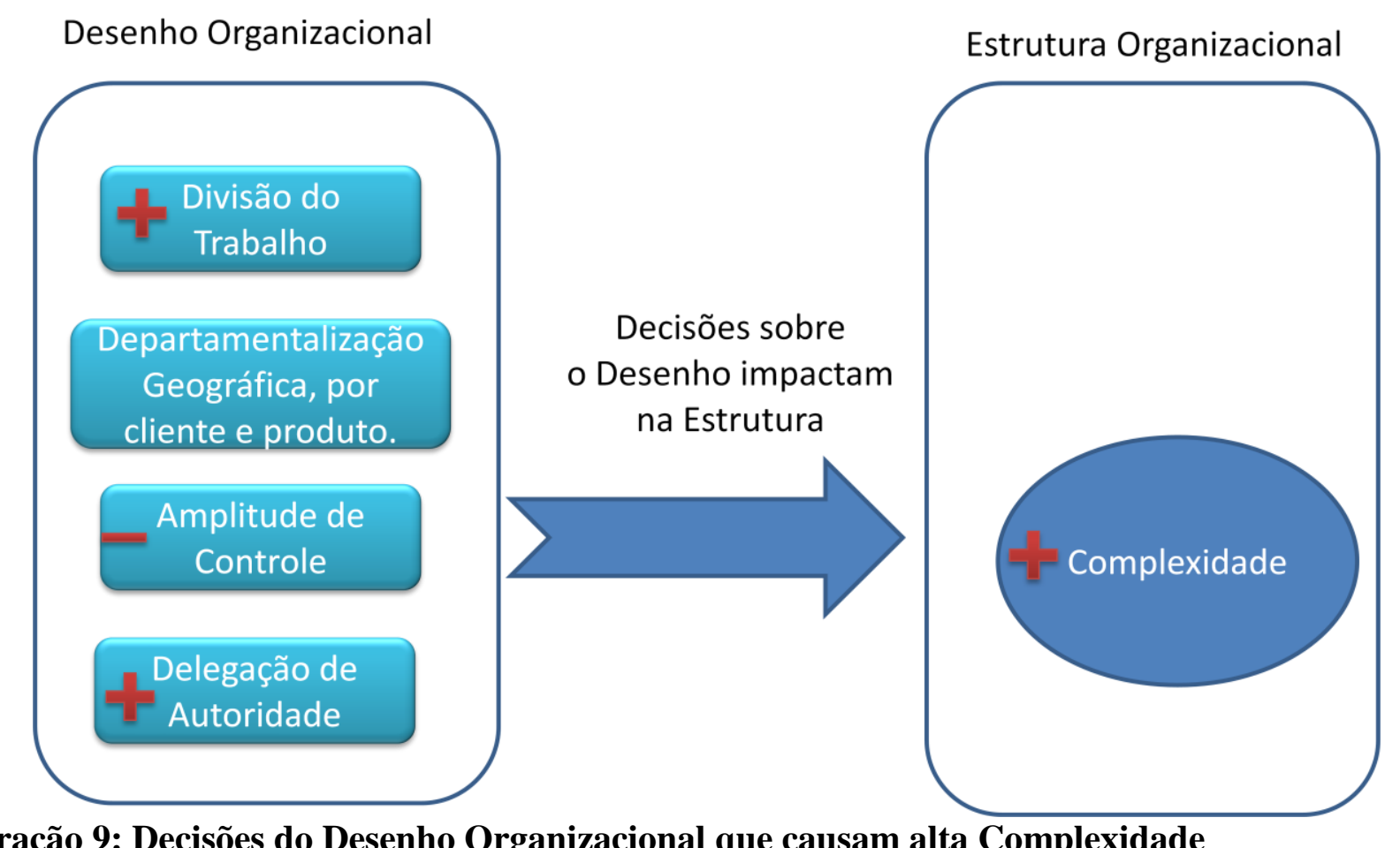

Ilustração 9: Decisões do Desenho Organizacional que causam alta Complexidade 


\section{Fonte: O autor, baseado nos conceitos de Gibson, Ivancevich e Donnelly (1991)}

A Ilustração 9 mostra as seguintes relações das Decisões Organizacionais na Complexidade:

- A maior divisão do trabalho aumenta a diferenciação horizontal.

- Maior delegação cria uma maior cadeia de autoridade que, por sua vez, aumenta a diferenciação vertical.

- As departamentalizações por geografia, cliente e produto criam maior complexidade, pois cada departamento pode virar uma nova unidade quase independente, aumentando assim níveis e complexidade.

- Se a amplitude de controle é menor, significa que as atividades são mais complexas. Logo, é necessário que a gestão esteja mais próxima, o que cria mais níveis e divisão, aumentando assim a complexidade.

Hall (1982) apresenta uma revisão de diversos autores sobre a diferenciação horizontal, mas, a princípio, duas linhas se destacam:

- A maior complexidade está relacionada com a dificuldade de suas atividades e o quanto treinamento é necessário para um trabalhador desenvolver certa atividade.

- A outra definição está relacionada com a visão de Gibson, Ivancevich e Donnelly (1991): quanto maior divisão do trabalho, áreas e funções, maior será a complexidade.

Sobre a diferenciação vertical, Hall (1982) diz que este é menos complexo que a horizontal, sendo que a relaciona à quantidade de níveis hierárquicos, de acordo com a visão de Gibson, Ivancevich e Donnelly (1991).

Dispersão Espacial também é considerada uma variável da complexidade por Hall (1982). Esta variável diz respeito à existência de unidades separadas espacialmente, por exemplo, rede de lojas ou assistências técnicas, quanto maior o número e mais espaçadas mais complexa é a estrutura.

Robbins (1983) define a Complexidade como o grau de diferenciação que existe dentro da organização e separa a complexidade em três variáveis:

- Diferenciação Horizontal: o grau de diferenciação entre as unidades da empresa, no que diz respeito à orientação dos funcionários, natureza das atividades e treinamento e educação dos trabalhadores. Quanto maior o número de funções diferentes que necessitam de conhecimento e habilidades específicas que uma organização precisa ter, mais complexa ela é. Departamentalização e especialização do trabalho são evidências de Diferenciação Horizontal.

- Diferenciação Vertical: é referente ao número de níveis hierárquicos presentes na organização. Quanto maior a diferenciação vertical, é preciso atenção, pois maiores as chances de distorção de comunicação do topo para a base operacional e maior a dificuldade do topo enxergar e coordenar o time operacional. As diferenciações verticais e horizontais devem ser vistas em conjunto; o aumento da vertical poder ser uma resposta ao aumento da 
horizontal. A discussão entre empresas achatadas ou não deve ser tratada de forma simplista, pois existem aspectos contraditórios.

- Dispersão Espacial: o quanto as instalações e pessoas estão dispersas geograficamente.

Robbins (1983) aponta que, conforme ocorre o crescimento das empresas, a complexidade tende a ser maior e os gestores devem atentar-se a ela, pois alguns aspectos podem ser comprometidos, como a comunicação. Se as organizações desejam ser efetivas, elas precisam de boa comunicação, coordenação e controle, porém quanto mais complexa é a organização, maior é a necessidade destes elementos, bem como a utilização de sistemas de controle, comitês e manuais formais de políticas.

Price (1972) considera uma organização complexa se esta possuir diversos níveis hierárquicos (diferenciação vertical) e muitas áreas diferentes e subunidades (diferenciação horizontal).

Este conceito apresenta definições distintas, porém uma grande parcela da literatura considera que a Complexidade é formada pela diferenciação vertical e horizontal, bem como a dispersão espacial.

\subsection{Dimensão Integração}

Conforme já discutido, grande parte dos autores consideram as dimensões Formalização, Centralização e Complexidade como principais. Nesta pesquisa, será também considerada a dimensão Integração, devido ao seu destaque na Cadeia de Suprimentos. Segundo Robbins (1983), Integração é qualidade de colaboração entre os departamentos para que estes trabalhem em conjunto e atinjam um único conjunto de esforços entre unidades organizacionais. No próximo item, será discutido com mais detalhes a definição desta dimensão na Cadeia de Suprimentos

\subsection{Dimensões da Estrutura Organizacional na Cadeia de Suprimentos}

Alguns pesquisadores da cadeia de suprimentos já trabalharam com os conceitos de estrutura organizacional no contexto da cadeia de suprimentos, mas nem todos utilizam os mesmos termos. As definições utilizadas nesta pesquisa serão baseadas nestes autores.

As dimensões da Estrutura deverão ser analisadas em uma Cadeia de Serviços. Choi e Hong (2002) utilizaram as três dimensões - Formalização, Complexidade e Centralização na Cadeia de Suprimentos, da seguinte forma:

- Formalização na Cadeia de Suprimentos diz respeito a como a rede é controlada por regras, normas e procedimentos explícitos que orientam a conduta, as obrigações e direitos que as empresas dentro da rede possuem. Logicamente, não é possível existir uma regra que coordene toda a cadeia, então neste contexto essas normas ocorrem entre as díades, empresa a empresa. Choi e Hong (2002) também destacam o conceito de Base de Fornecedores, que são as empresas que estão em relação de díade com o comprador. Quanto 
maior as Bases de Fornecedores, mais formalização deve ser encontrada nas relações, para alcançar padronização e controle dos fornecedores.

- Centralização na Cadeia de Suprimentos diz respeito a quanto a indústria, ao final da cadeia, exerce de poder e controle sobre os fornecedores. Assim, uma cadeia centralizada é aquela em que o comprador final é quem toma as decisões. Considerando uma cadeia real, um comprador jamais poderia decidir por todos os seus fornecedores. Neste caso, supondo uma sequência de camadas de fornecedores, por exemplo, comprador que contrata fornecedor A, que por sua vez contrata fornecedor B e assim por diante, a centralização será observada de acordo com quantas camadas de fornecedores o comprador se envolve. Por exemplo, se o cliente da Ilustração 10 controla somente a $1^{\text {a }}$ camada de fornecedores, a cadeia é descentralizada; porém, se ele controla até alguns dos principais fornecedores da $3^{\mathrm{a}}$ camada, a cadeia é centralizada.

- Complexidade. Para poder avaliar a complexidade, é necessário, inicialmente, obter o mapa dos fornecedores. Uma vez com o mapa disponível, é necessário somente contar os níveis e os participantes em cada nível. Choi e Hong (2002) também destacam que, ao contrário da Formalização e Centralização, que são observados na relação de díade, a Complexidade é observada na rede ou cadeia.

Kim (2006) utilizou e definiu os conceitos de Formalização e Centralização:

- Formalização diz respeito sobre o nível de padronização das tarefas e trabalho da organização, para a cadeia. Este conceito é definido até qual grau os relacionamentos e tomadas de decisão são governados por regras formalizadas, e políticas de procedimentos padronizados (KIM, 2006).

- O conceito de Centralização na cadeia diz respeito à concentração de poder nas tomadas de decisão por uma empresa dentro cadeia (KIM, 2006).

A Complexidade aumenta quanto maior é o número de empresas que formam a cadeia e quanto mais diferentes forem umas das outras. Quanto maior a complexidade, mais dificuldades ocorrem na operação da cadeia (BOYLE, HUMPHREYS e McIVOR, 2008).

Halley e Nollet (2002) entendem que a Centralização na cadeia de suprimentos está relacionada à concentração de atividades de comando e poder na tomada de decisão nas mãos de um grande cliente, criador de pedidos.

Moser, Kern, Wohlfarth e Hartmann (2011) trabalham o conceito de Centralização sendo este relacionado com a autoridade e poder de uma organização na cadeia de suprimentos.

Comparando a Ilustração 10 com a Ilustração 11, é possível associar o conceito de Complexidade da Teoria Organizacional com a Cadeia de Suprimentos, porém os autores Ketchen e Hult (2010) irão questionar as vantagens e limitações sobre como as teorias organizacionais são apropriadas para a gestão da cadeia de suprimentos. 


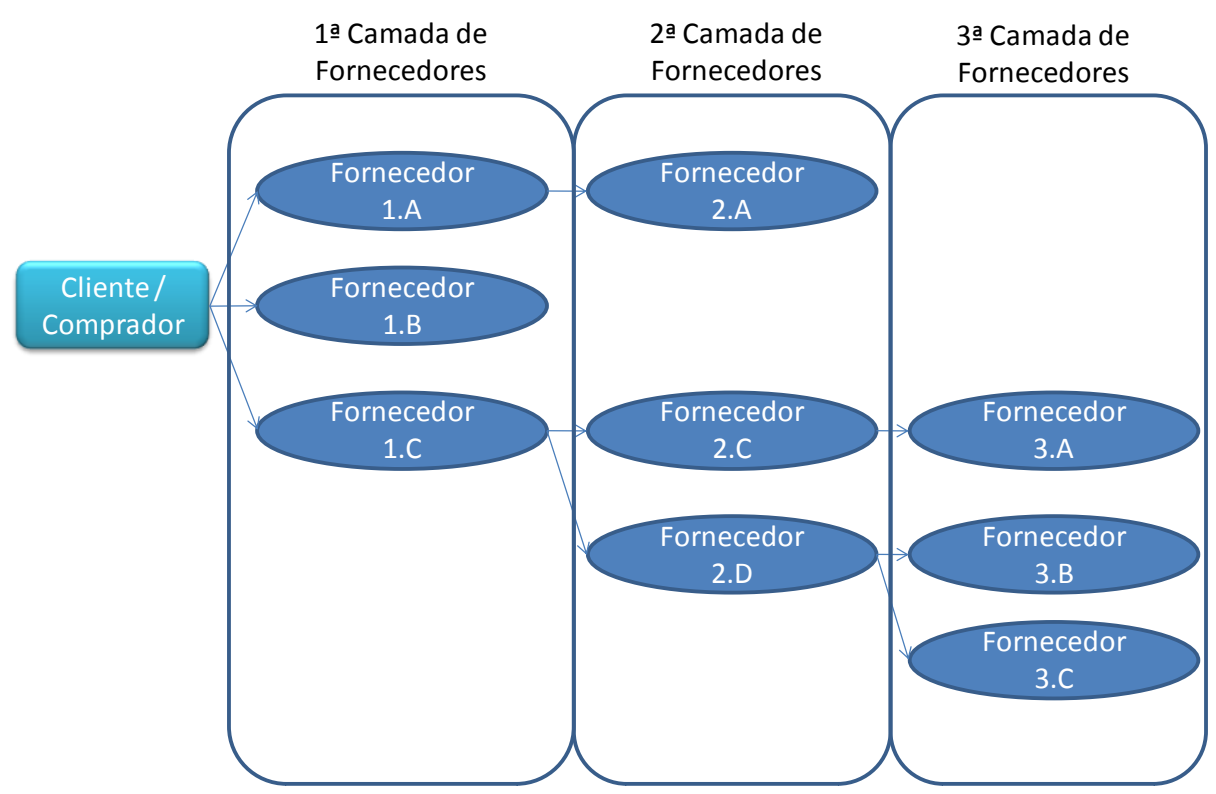

Ilustração 10: Exemplo de Cadeia com 3 Camadas de fornecedores

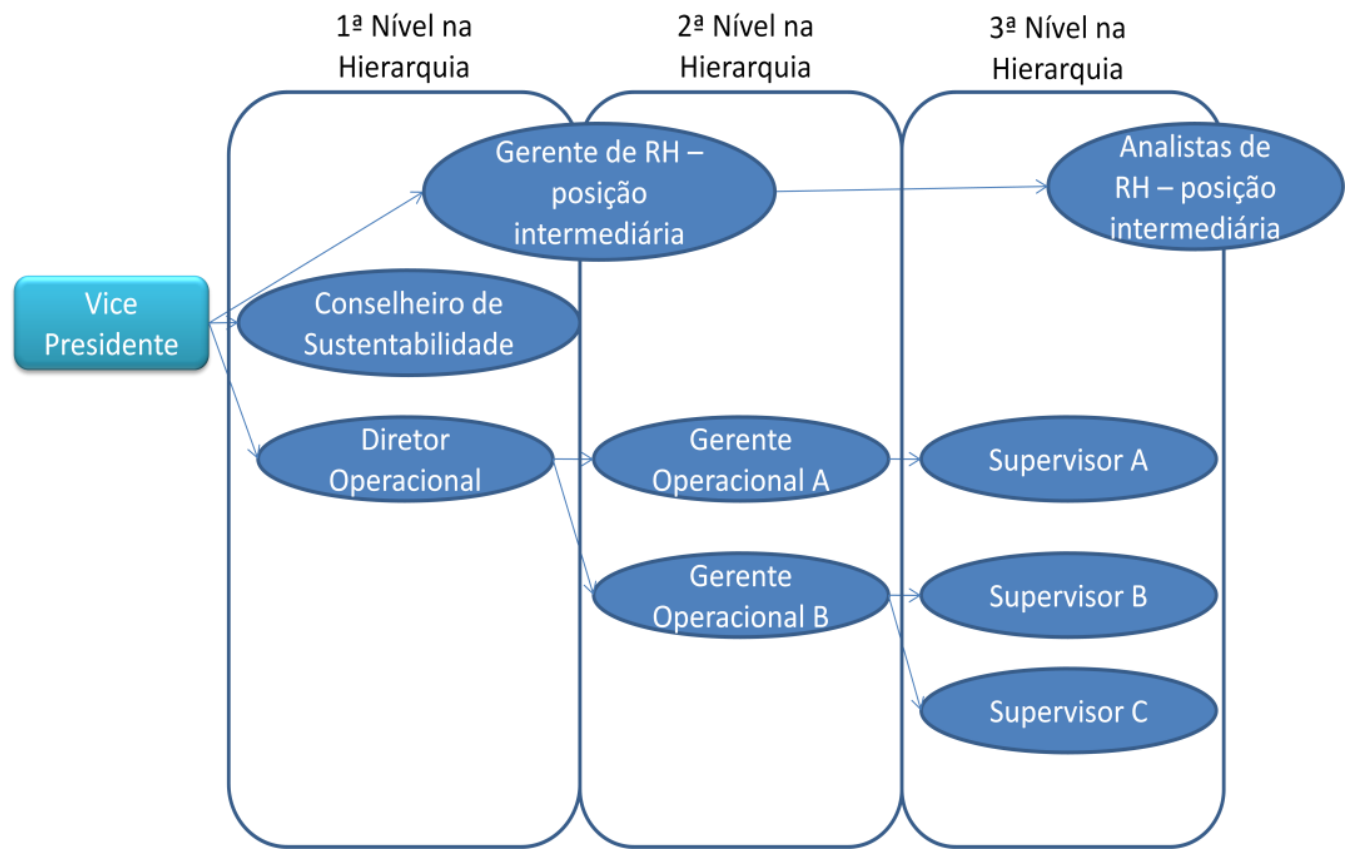

Ilustração 11: Exemplo de Organização com 3 níveis hierárquicos 


\subsection{Dimensões Estruturais e sua aplicação na Cadeia de Suprimentos}

Tabela 6: Dimensões da Estrutura Organizacional e sua aplicação no contexto de Cadeia de Suprimentos

\begin{tabular}{|c|c|c|}
\hline Dimensões & $\begin{array}{l}\text { Definição da Teoria } \\
\text { Organizacional }\end{array}$ & $\begin{array}{c}\text { Como as dimensões se manifestam na } \\
\text { Cadeia de Suprimentos? }\end{array}$ \\
\hline Centralização & $\begin{array}{l}\text { Relativo à concentração de } \\
\text { poder e tomada de decisão } \\
\text { em um nível da alta gestão. } \\
\text { (ROBBINS, } \\
\text { (GIBSON, IVANCEVICH } \\
\text { E DONNELLY, 1991) } \\
\text { (PRICE, 1972) }\end{array}$ & $\begin{array}{l}\text { É a distribuição ou concentração de poder e } \\
\text { autoridade para a tomada de decisão ao } \\
\text { longo da cadeia. Por exemplo, se a indústria } \\
\text { gerencia somente a camada de fornecedores } \\
\text { diretos, a cadeia é descentralizada. Porém, } \\
\text { conforme a sua autoridade atinge outras } \\
\text { camadas de fornecedores, a Centralização é } \\
\text { considerada maior (KIM, 2006) (CHOI E } \\
\text { HONG, 2002). }\end{array}$ \\
\hline Complexidade & 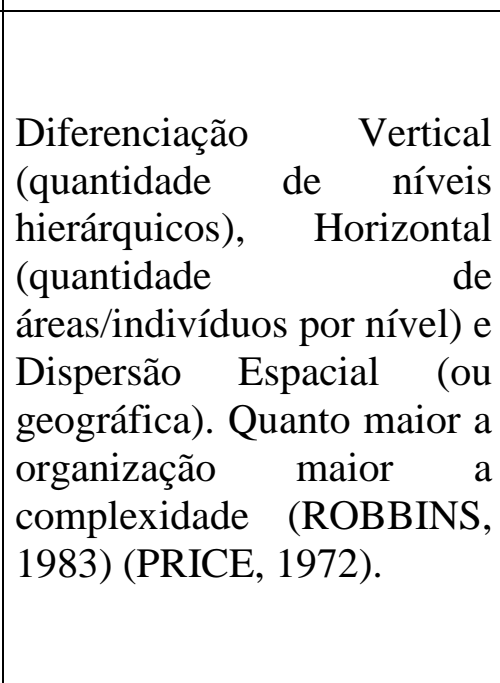 & $\begin{array}{l}\text { É o conjunto da diferenciação vertical, } \\
\text { horizontal e a dispersão espacial. Na Cadeia } \\
\text { de Suprimentos, a diferenciação vertical se } \\
\text { traduz na quantidade de camadas de } \\
\text { fornecedores e a diferenciação horizontal, } \\
\text { por sua vez, é a quantidade de fornecedores } \\
\text { por camada. A Dispersão Espacial será } \\
\text { considerada pela distância geográfica entre } \\
\text { os participantes da cadeia (BOYLE, } \\
\text { HUMPHREYS e MCIVOR, 2008) (CHOI E } \\
\text { HONG, 2002). No caso de serviços, a } \\
\text { utilização de fornecedores prestando } \\
\text { serviços distintos uns dos outros adiciona } \\
\text { complexidade à cadeia. }\end{array}$ \\
\hline Formalização & \begin{tabular}{|lr}
\multicolumn{3}{l}{ Relativo ao nível de regras } \\
que explícitas na \\
Organização & (GIBSON, \\
IVANCEVICH & \\
DONNELLY, & 1991) \\
(PRICE, 1972). & \\
\end{tabular} & $\begin{array}{l}\text { É entendida como a explicitação das regras, } \\
\text { procedimentos e valores, independente do } \\
\text { fato de estarem escritos ou não, e como } \\
\text { essas regras influenciam as tomadas de } \\
\text { decisão e relacionamentos. Esta dimensão } \\
\text { será analisada no nível de relacionamentos, } \\
\text { fornecedor-cliente (KIM, 2006) (CHOI E } \\
\text { HONG, 2002). }\end{array}$ \\
\hline Integração & $\begin{array}{l}\text { É a capacidade de } \\
\text { colaboração entre os } \\
\text { departamentos para que } \\
\text { estes trabalhem em grupo e } \\
\text { atinjam um único conjunto } \\
\text { de esforços entre unidades } \\
\text { organizacionais. } \\
\text { (ROBBINS, 1983) }\end{array}$ & $\begin{array}{l}\text { É a colaboração, criação de objetivos em } \\
\text { comum, baseados na confiança entre } \\
\text { empresas e o compartilhamento de ganhos. } \\
\text { Por exemplo, dois fornecedores que } \\
\text { atendem um mesmo cliente ou, então, um } \\
\text { fornecedor e o seu cliente (COUGHLAN et. } \\
\text { al. 2003). }\end{array}$ \\
\hline
\end{tabular}


Considerando a interligação entre as dimensões Centralização, Formalização e Integração, a questão do relacionamento entre os agentes da cadeia ganha destaque, pois todas estas dimensões podem ser captadas em uma díade, por exemplo, cliente e fornecedor. Assim, nos próximos três sub-tópicos serão discutidos o conceito e as dificuldades de relacionamento e colaboração entre estes agentes da cadeia.

\title{
2.14.1 O relacionamento entre os Agentes da Cadeia
}

\author{
"Por sua vez, os relacionamentos assumem um papel de destaque dentro de \\ qualquer cadeia de abastecimento, já que esta é composta por diferentes organizações \\ internas e externas (clientes, fornecedores de materiais e serviços, distribuidores etc.), \\ que se envolvem em fluxos bidirecionais de materiais, produtos, informações e \\ insumos monetários.” (TORRES JUNIOR e RATÃO, 2011)
}

A dimensão centralização ocorre no nível de relacionamentos, por isso é imprescindível fazer uma análise mais detalhada deste tema.

\subsubsection{Alianças, Parcerias, Cooperação e Colaboração}

Esta revisão apresenta a colaboração com diferentes graus de intensidade e maturidade e até mesmo com outras denominações, mas com o mesmo sentido de maior abertura de trocas de informações, dados entre diversos níveis da estrutura.

Das e Teng (1998) trabalham o conceito de Alianças Estratégicas, as quais envolvem a busca por objetivos compartilhados entre dois ou mais parceiros destacando a importância da colaboração e das incertezas. Assim, segundo estes autores, nesta filosofia as empresas não atuam de forma oportunista nem desonesta, mas privilegiam a colaboração e comprometimento, agindo de acordo como os contratos. Esta abordagem pode ser paradoxal uma vez que as empresas possuem interesses individuais e se esforçam para alcançá-los, neste contexto Das e Teng (1998) propõe que o ideal é um equilíbrio entre competição e cooperação.

Corbett, Blackburn e Van Wassenhove (1999) destacam a importância da confiança para que seja possível facilitar a comunicação e torná-la mais aberta, estes autores ainda defendem que mesmo parcerias menores podem proporcionar ganhos operacionais.

A colaboração, diferentemente da cooperação, é definida por Coughlan et al. (2003) como a tomada de decisão entre organizações envolvendo compartilhamento das decisões e responsabilidades pelos resultados, para tanto é essencial o desenvolvimento de relações de longo-prazo, confiança, engajamento. Assim, as empresas participantes da colaboração podem encontrar novos mercados, habilidades e desenvolver ganhos operacionais. Em acordo com estes autores Powell, Koput e Smith-Doerr (1996) e Austin (2001) destacam que a colaboração é uma aliança que se manifesta de diversas formas, às vezes através de parcerias em áreas de pesquisa e desenvolvimento, manufatura e co-marketing.

Powell, Koput e Smith-Doerr (1996) citam entre os benefícios da colaboração o compartilhamento de riscos e também apresentam dificuldades para a efetiva colaboração, como a falta de confiança entre as partes, projetos de alta complexidade. 
Ha, Park e Cho (2010) e Soosay, Hyland e Ferrer (2008) também destacam a necessidade de compartilhamento de riscos, trabalho em conjunto, confiança e comunicação para o desenvolvimento da colaboração.

Leeuw e Fransoo (2009) afirma que o conceito de colaboração ainda precisa ser melhor definido e que esta é essencial, pois as empresas nunca conseguem desenvolver negócios sozinhas. Outros autores como Vereecke e Muylle (2006) definem diferentes níveis de colaboração, desde a operacional com foco nas melhorias na eficiência transacional e a estratégica, na qual existe demanda por objetivos compartilhados.

O conceito de Coughlan et al. (2003) de colaboração como um processo de decisão conjunta e de compartilhamento de resultados entre os parceiros, o qual leva em consideração possíveis dificuldades de implementação, será utilizado para a análise da dimensão Integração na Cadeia de Suprimentos.

\subsubsection{Dificuldades e Barreiras à Colaboração na Cadeia de Suprimentos}

Corsten e Kumar (2005), como Coughlan et al. (2003) e Powell, Koput e Smith-Doerr (1996), estudam as barreiras a colaboração, estes autores afirmam que, apesar de relações colaborativas produzirem inúmeros benefícios, existe uma tensão entre maximizar o valor da operação e distribuí-lo entre os parceiros. Hamel (1991) também destaca que como em uma corrida ambos os parceiros querem ganhar o máximo de conhecimento que seu parceiro tem a oferecer no relacionamento e quem consegue adquirir o máximo em menor tempo torna o outro parceiro desnecessário, pois este não é mais importante para ganhar conhecimento. Estes autores demonstram que embora muito seja discutida pela literatura a colaboração não é óbvia e simples de se executar.

Corbett, Blackburn e Van Wassenhove (1999) ainda destacam a dificuldade em casos onde o histórico do relacionamento entre os parceiros inclui anos de exploração de um sobre o outro.

\subsection{Transportes no Brasil}

Conforme destacado na introdução, dentro do mercado de serviços, o mercado de transportes é muito expressivo, segundo Pesquisa Anual de Serviços 2011 do IBGE, o setor de transporte representa em torno de $30 \%$ de toda receita líquida do setor de serviços do país, sendo que serviços representam em torno de $70 \%$ do PIB nacional.

No setor de transportes um novo ator apareceu nos últimos 20 anos e ganhou muito destaque. Os Operadores Logísticos são responsáveis por consolidar a prestação de diversos serviços, como armazenagem, transporte, controle de informações, redesenho de cadeia de suprimentos, entre outros.

Seguem os principais tipos de transportes de cargas vendidos:

- Lotação - FTL (Full Truck Load): neste modo, o cliente paga pela viagem do veículo, independente de quanta carga ele levar. Obviamente, deve ser respeitado o limite de carga (peso e volume) do veículo em questão. 
- Fracionado - LTL (Less than a (Truck) Load): nesta modalidade, o cliente paga somente pelo volume ou peso (qual for o maior) que está ocupando no veículo.

- Aéreo Fracionado - Cargas de alto valor: geralmente, está relacionada ao transporte fracionado, só que com aviões, ao invés de caminhões.

- Transporte especial - cargas perigosas ou de dimensões especiais: é como um transporte lotação, mas com planejamento de rota especial e acompanhamento de batedores se necessário.

- Adicionais: Escolta, Seguro, Caminhão Blindado, taxa por entrega e estadia. Em transportes existem muitos adicionais que se somam ao primeiro preço de transportes.

- Marítimo: Balsa (cargas de Manaus) ou cabotagem. Geralmente é pago o fracionado.

- Frota dedicada: Nesta modalidade, o fornecedor deixa um veículo à disposição do cliente. Seja ele utilizado ou não, o cliente deverá pagar um valor fixo por período, por exemplo, mensal.

\subsection{Logística e Operadores Logísticos}

A cadeia analisada neste trabalho contém um operador logístico, a seguir será revista a literatura sobre este tema.

Conforme Figueiredo e Mora (2009) diversos termos são utilizados para se referir a Operadores Logísticos, por exemplo, Prestadores de Serviços Logísticos (PSL ou SLP Service Logistic Provider), Third-party Logistics (3PL), provedor de logística integrada, empresas de logística contratada (contract logistics companies).

Apesar das diversas definições encontradas na literatura, diversos autores (KOPCZAK, 1997; HALLDÓRSSON e SKJØTT-LARSEN, 2004; MCGINNIS, KOCHUNNY e ACKERMAN, 1995) concordam que os operadores logísticos executam serviços básicos de logística como armazenagem e transportes ou ainda embalagem e customização. Fleury, Wanke e Figueiredo (2000), Vivaldini e Pires (2010) e Halldórsson e SkjØtt-Larsen (2004) ainda apontam a capacidade do Operador Logístico de entregar soluções customizadas, personalizadas, desenvolvimento de projetos como se fosse uma empresa de consultoria. Fleury, Wanke e Figueiredo (2000) destacam também que o valor agregado pelo operador logístico pode ser grande em casos de cadeias complexas nas quais após se terceirizar os serviços a empresa pode focar na sua atividade principal.

Este trabalho utilizará a definição de Halldórsson e SkjØtt-Larsen (2004), na qual, no mínimo, o operador deve prestar serviços de armazenagem e transporte.

Knemeyer e Murphy (2004) apontam a crescente importância dos Operadores Logísticos em todo mundo e não somente nos Estados Unidos, como a literatura tem indicado.

Vivaldini e Pires (2010) também demonstram o outro lado, os riscos na terceirização, entre eles a perda de próximo controle das operações e a falta de liberdade das empresas que ficam presas ao Operador Logístico, pois trocar uma parceria deste tipo é mais complexo, assim uma análise criteriosa deve ser feita antes da contratação de um Operador Logístico. 


\section{METODOLOGIA}

\subsection{Delineamento da Pesquisa}

A análise qualitativa depende de muitos fatores, tais como a natureza dos dados coletados, a extensão da amostra, os instrumentos de pesquisa e os pressupostos teóricos que nortearam a investigação. Pode-se, no entanto, definir esse processo como uma sequência de atividades que envolve a redução dos dados, a categorização desses dados, sua interpretação e a redação do relatório (Gil, 1991). Este trabalho, por sua natureza exploratória, é de caráter qualitativo.

Martins e Theóphilo (2009) identificam três situações nas quais os indicadores qualitativos são mais relevantes:

1. Situações nas quais a evidência qualitativa substitui a simples informação estatística relacionadas a épocas passadas.

2. Para capturar dados psicológicos.

3. Para descobrir e entender a complexidade e a interação de elementos relacionados ao objeto de estudo.

Neste projeto, a sua questão básica: "Como as dimensões estruturais concebidas em um contexto de administração intraorganizacional de empresas se manifestam em sua aplicação na gestão da cadeia de suprimentos? Quais benefícios, limitações e oportunidades?" se enquadra no item 3 citado acima, ou seja, entender a Complexidade e a interação das dimensões estruturais na Cadeia de Suprimentos.

Segundo Yin (2010), o Estudo de Caso é apropriado quando são propostas questões "como" e "por que", bem como entender fenômenos sociais complexos. Foi escolhido o método Estudo de Caso, pois nesta investigação será analisado "como" as dimensões estruturais explicam o comportamento e operação da cadeia de suprimentos. Considerando o foco desta pesquisa em compreender a utilização deste empréstimo conceitual e melhor entender a operação e comportamento da cadeia, esta pesquisa é classificada como descritiva.

Neste trabalho, foi analisada uma cadeia com três unidades de análise, o relacionamento entre cliente e fornecedor, para serem examinadas. $\mathrm{O}$ caso é uma cadeia de serviços de transporte de carga. 


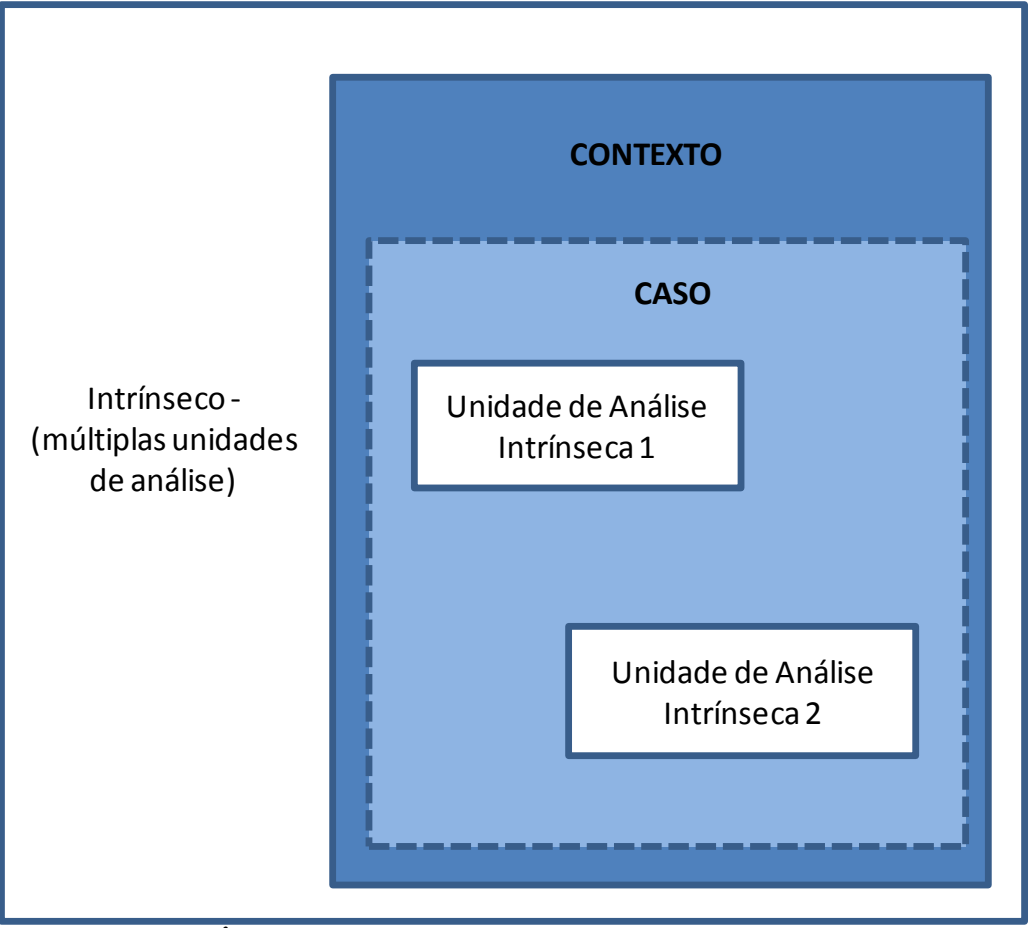

Ilustração 12: Estudo de Caso Único com múltiplas unidades de análise Fonte: Yin (2010)

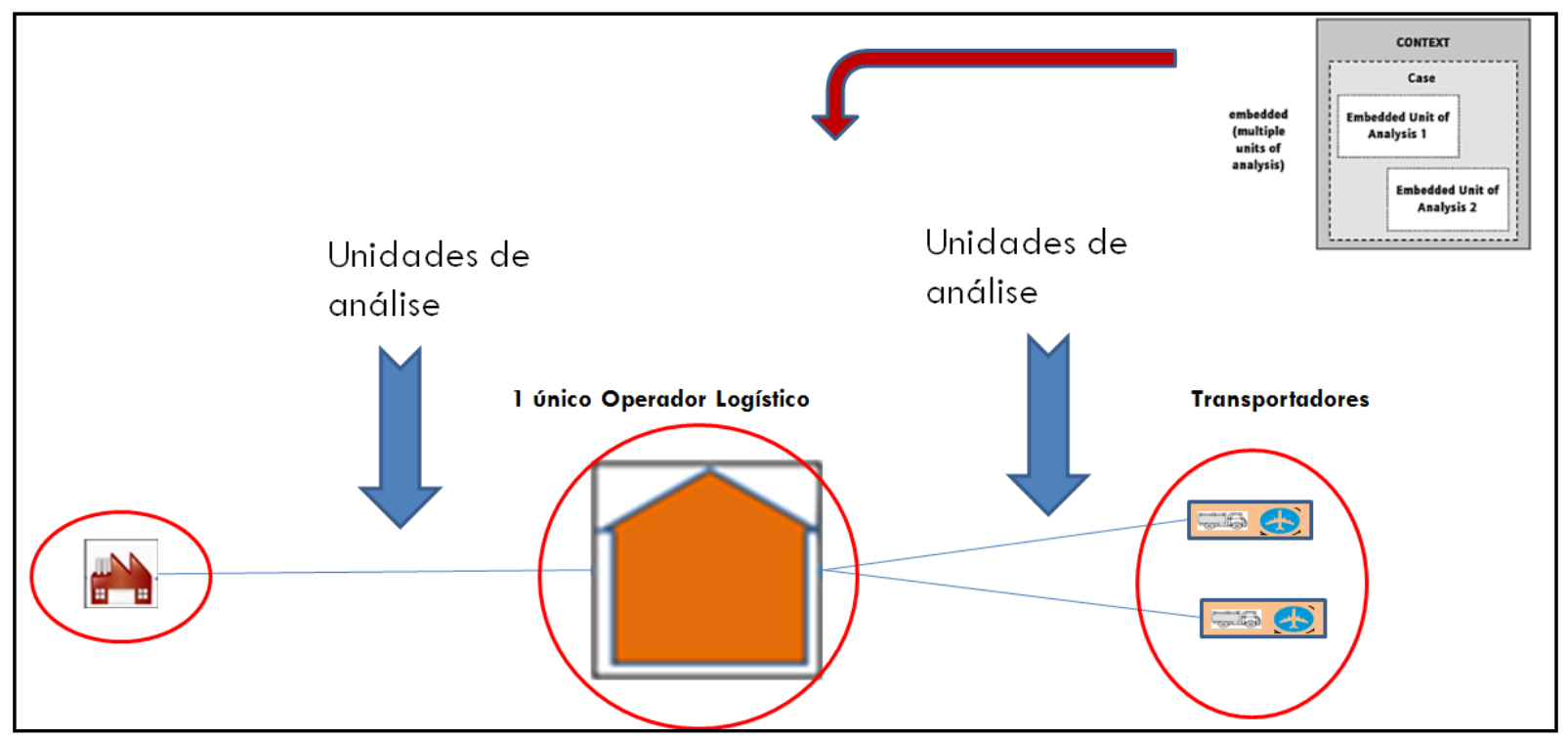

Ilustração 13: Esquema da Cadeia de Serviços e das unidades de análise Fonte: Autor 
As ilustrações 12 e 13 demonstram o estudo de caso único com diversas unidades de análise, segundo Yin (2010).

\subsection{Coleta de dados}

Em estudos de caso Yin (2010) indica a utilizadas de entrevistas focadas, as quais podem ter um estilo mais conversacional e aberta, porém costumam seguir um protocolo do estudo de caso.

Para esta pesquisa foi desenvolvido como instrumento de coleta um questionário parcialmente estruturado que será utilizado em uma entrevista, na qual o entrevistado possui abertura para colaborar com outras informações além das perguntas. O questionário levou em consideração a teoria de Estrutura Organizacional no contexto de Cadeias de Suprimentos

Martins e Theóphilo (2009) afirmam que o objetivo da entrevista é compreender o significado que os entrevistados atribuem às questões e às situações, em contextos que não foram estruturados anteriormente, com base nas suposições e conjecturas do pesquisador.

Para as entrevistas serão selecionadas quatro empresas de grande expressão dentro da cadeia de Serviços:

- 1 indústria.

- 1 operador logístico.

- 2 transportadores.

Serão feitas três entrevistas por empresa:

- Vendedor que possua relacionamento com o cliente.

- Comprador que possua relacionamento com o fornecedor.

- Gerente operacional.

As mesmas perguntas serão feitas para entrevistados diferentes, para confrontação da informação. Os respondentes deverão ter grande contato comercial ou operacional com os outros agentes da cadeia.

Além das entrevistas, também foram analisados documentos: lista de fornecedores, contratos, relatórios de indicadores operacionais e também será feita coleta de dados por observação durante as visitas, conforme Yin (2010) exemplifica, pois essa coleta de dados por meio de entrevista, documentos e observação caracteriza uma triangulação na coleta de dados.

\subsection{Protocolo de Pesquisa}

Segundo Yin (2010), o Protocolo é mais do que o questionário, ou seja, este é contido pelo protocolo. A utilização de um Protocolo é altamente recomendada e aumenta a confiabilidade da pesquisa de estudo de caso.

Yin (2010) propõe que um protocolo tenha as seguintes seções:

- Visão geral do projeto - objetivos, leituras relevantes e etc.. 
- Procedimentos de Campo (proteção dos participantes, fontes de dados e advertências de procedimentos).

- Questões.

- Um guia para o relatório.

\subsection{Visão Geral do Projeto}

O trabalho intitulado "Abordagem da cadeia de suprimentos na perspectiva das dimensões da estrutura organizacional: um estudo de caso na cadeia de serviços logísticos" tem como objetivo conceber a titulação de Mestre em ciências para o pesquisador Luiz Daniel Maffei Matsumato.

A pesquisa tem por objetivo principal compreender quais das dimensões da Análise de Estrutura Organizacional podem ser utilizadas para se analisar uma Cadeia de Serviços e qual compreensão da Cadeia a análise dessas dimensões proporciona. Como objetivos secundários essa pesquisa deve:

- Identificar as principais dimensões da análise de Estrutura Organizacional com conceito potencial para aplicação na Cadeia de Serviços Logísticos.

- Identificar uma cadeia de serviços logísticos e mapear seus agentes.

- Descrever a Cadeia de Serviços Logísticos sob a perspectiva das dimensões da Estrutura Organizacional.

Essa investigação justifica-se devido à ocorrência de conceitos estruturais de organizações na cadeia de suprimentos, conforme diversos autores que utilizaram abordagens distintas apontam. Portanto, o problema investigado é entender como as dimensões estruturais ocorrem em uma cadeia de serviços e em que grau conseguem gerir a cadeia estudada em questão.

O caso foi selecionado de acordo com a experiência prévia do pesquisador, além do tema de transporte estar em destaque no cenário nacional, devido ao setor logístico ser uma atual barreira ao desenvolvimento do país, uma vez que a falta de eficiência deste implica diretamente no aumento dos custos dos produtos nacionais, diminuindo sua competitividade. Foi considerado, também, o fato de transportes ser um serviço de alta tangibilidade (GIANNAKIS, 2011), assim permitindo a aplicação de controles e metas pelas empresas. Isto significa maiores chances de visualizar com clareza algumas dimensões como formalidade.

\subsection{Procedimentos de Campo}

Antes de se iniciar a entrevista, devem ser feitas algumas preparações:

- Enviar previamente o termo de confidencialidade e autorização e coletar assinatura, caso a empresa autorize divulgar os nomes verdadeiros.

- Avisar que as informações são confidenciais.

- Anotar data, horário de início e fim da entrevista e também o local - caso seja por telefone ou via internet também deve ser registrado.

- Explicar ao entrevistado qual é o projeto, como são as perguntas e que ele possui liberdade para responder como achar melhor e, se tiver alguma dúvida 
sobre as questões, tem liberdade para perguntar. Avisá-lo que será enviado um resumo executivo ao final do projeto como retorno.

- Confirmar com o entrevistado a sua disponibilidade de tempo.

- Mostrar um mapa de cadeia de serviços como exemplo.

- Lembrar sempre de deixar o entrevistado falar a vontade e não induzi-lo.

- Complementar as anotações logo após a entrevista e revisá-las.

- Ao final da entrevista, deixar claro para o entrevistado que, se ele quiser, poderá a qualquer momento fazer comentários adicionais. Também perguntar se perguntas adicionais poderão ser feitas posteriormente.

\subsection{Questionário}

Tabela 7: Questionário Dimensões e Caracterização

\begin{tabular}{|l|l|}
\hline & \multicolumn{1}{|c|}{ CARACTERIZAÇÃO (EMPRESA E ENTREVISTADO) } \\
\hline 1 & Qual o seu cargo e função? \\
\hline 2 & Há quantos anos você está na empresa? Há quantos anos nesta função? \\
\hline 3 & Qual o número de funcionários? \\
\hline 4 & Qual o faturamento anual? \\
\hline 5 & Qual o total em compras de serviços logísticos? \\
\hline & \multicolumn{1}{|c|}{} \\
\hline 6 & Quais serviços a sua empresa vende? \\
\hline 7 & Quantos clientes e quantos fornecedores vocês possuem? \\
\hline \hline 8 & $\begin{array}{l}\text { Quais áreas de sua organização são responsáveis pelo contato com o cliente e com os } \\
\text { fornecedores? }\end{array}$ \\
\hline \hline 9 & $\begin{array}{l}\text { Por favor, me dê uma ideia geral da operação: pedido (faturamento), coleta, } \\
\text { entrega. Frequência de coleta. Modais utilizados. E acompanhamento. }\end{array}$ \\
\hline & \multicolumn{1}{|c|}{ Perguntas sobre fornecedores } \\
\hline & Quantos sobre o cliente \\
\hline 10 & Quano os fornecedores que atuam para este laboratório? \\
\hline 11 & Quais são os fornecedores mais importantes ou de maior expressão? Por quê? \\
\hline 12 & $\begin{array}{l}\text { Há quanto tempo vocês trabalham com estes fornecedores? Como é o histórico } \\
\text { comercial e operacional? Eles apresentam boa performance? }\end{array}$ \\
\hline \hline 13 & Confirme o tipo de serviço que vocês prestam para este cliente. \\
\hline 15 & Qual a importância desta conta para vocês? Por quê? \\
\hline 16 & $\begin{array}{l}\text { Há quanto tempo vocês possuem esta parceria? Como é o histórico comercial e } \\
\text { operacional? Vocês apresentam boa performance? }\end{array}$ \\
\hline 17 & Está conta é lucrativa? \\
\hline \hline
\end{tabular}




\section{1 - CENTRALIZAÇÃO}

É a distribuição ou concentração de poder e autoridade para a tomada de decisão ao longo da cadeia. Por exemplo, se a indústria interfere somente na camada de fornecedores contratados diretamente, a cadeia é descentralizada, porém conforme a sua autoridade atinge outras camadas a Centralização é considerada maior (KIM, 2006) (CHOI E HONG, 2002).

\section{SOBRE O FORNECEDOR}

18 Qual o seu contato com os fornecedores?

19 Quando existem alterações de procedimentos e padrões da operação, o fornecedor é consultado? Vocês são consultados? (Existe colaboração?).

20 Como é feita a seleção de fornecedores? Quais são os critérios? (Preço, performance, histórico) Qual tem maior influência?

21 Como é feito o acompanhamento da performance dos fornecedores? (O controle é próximo? Relatórios e reuniões?)

22 Em média, há quanto tempo vocês trabalham com cada fornecedor? (Foco no longo ou curto prazo?).

23 Qual o principal motivo de troca de fornecedores?

24 Vocês praticam multas e bônus por performance da operação? (Maior controle, reforço positivo e negativo).

25 Em sua opinião, os seus fornecedores, em média, estão descontentes, satisfeitos ou muito satisfeitos em prestar serviços para vocês?

\section{SOBRE O CLIENTE}

26 Qual o seu contato com o cliente? (Contato comercial, entrevistado hábil para responder perguntas).

27 Como foi o processo de seleção que vocês participaram para ganhar a conta? Qual foi o principal critério? (Parceria internacional, experiência, qualidade ou preço).

28 Quando são necessárias mudanças na operação o cliente consulta vocês ou vocês consultam o cliente para desenvolver essas mudanças? (Existe colaboração?).

29 Em sua opinião, vocês estão descontentes, satisfeitos ou muito satisfeitos em prestar serviços para este cliente?

30 Os clientes aplicam multas e bônus por performance sobre vocês? 


\begin{tabular}{|c|c|}
\hline & 2 - FORMALIZAÇÃO \\
\hline \multicolumn{2}{|r|}{$\begin{array}{l}\mathbf{E} \text { entendida como a explicitação das regras, procedimentos e valores, } \\
\text { independente do fato de estarem escritas ou não, e como essas regras influenciam as } \\
\text { tomadas de decisão e relacionamentos. Esta dimensão será analisada no nível de } \\
\text { relacionamentos, fornecedor-cliente (KIM, 2006) (CHOI E HONG, 2002). }\end{array}$} \\
\hline 31 & $\begin{array}{l}\text { Quais documentos regulamentam a operação? } \\
\text { Sugestões: } \\
\text { - Contrato com clientes } \\
\text { - Contrato com fornecedores } \\
\text { - SLA - Acordo de Nível de Serviço } \\
\text { - Relatório de acompanhamento de performance } \\
\text { - Ata de reunião com Cliente } \\
\text { - Ata de reunião com Transportador } \\
\text { - Tabela de preços } \\
\text { - Regras de Segurança } \\
\text { - Apólice de Seguro? DDR - Dispensa de Direito de Regresso? } \\
\text { - Lista de fornecedores }\end{array}$ \\
\hline \multirow[t]{2}{*}{32} & $\begin{array}{l}\text { As regras/normas de funcionamento com o seu fornecedor são explícitas, estão } \\
\text { escritas? É do conhecimento de todos os envolvidos? }\end{array}$ \\
\hline & 3 - COMPLEXIDADE \\
\hline \multicolumn{2}{|r|}{$\begin{array}{l}\qquad \dot{E} \text { o conjunto da diferenciação vertical, horizontal e a dispersão espacial. Na } \\
\text { Cadeia de Suprimentos, a diferenciação vertical se traduz na quantidade de camadas de } \\
\text { fornecedores e a diferenciação horizontal, por sua vez, é quantidade de fornecedores por } \\
\text { camada. A Dispersão Espacial será considerada pela distância geográfica entre os } \\
\text { participantes da cadeia (BOYLE, HUMPHREYS e McIVOR, 2008) (CHOI E HONG } \\
\text { 2002). }\end{array}$} \\
\hline 33 & $\begin{array}{l}\text { (Entender com o entrevistado a localização da Indústria, Centros de Distribuição, } \\
\text { Operador Logístico e Principais Transportadores). }\end{array}$ \\
\hline \multirow[t]{2}{*}{34} & $\begin{array}{l}\text { (Escolher uma localização com volume médio e de importância para se fazer o } \\
\text { mapeamento até os últimos níveis de fornecedores). }\end{array}$ \\
\hline & 4 - INTEGRAÇÃO \\
\hline \multicolumn{2}{|r|}{$\begin{array}{l}\text { É a colaboração, criação de objetivos em comum e confiança, entre empresas que } \\
\text { precisam trabalhar em conjunto, por exemplo, dois fornecedores que atendem um } \\
\text { mesmo cliente e precisam trabalhar em conjunto, ou então, um fornecedor e o seu cliente } \\
\text { (COUGHLAN et. al. 2003). }\end{array}$} \\
\hline 35 & $\begin{array}{l}\text { Existe algum esforço entre as empresas da cadeia para a criação de colaboração? } \\
\text { (Colaboração é a criação de objetivos em comum e confiança) (COUGHLAN et. al. } \\
\text { 2003). }\end{array}$ \\
\hline & OUTRAS INFORMAÇÕES \\
\hline
\end{tabular}


Tabela 8: Questionário sobre autonomia para execução do serviço

\begin{tabular}{|c|c|c|c|c|c|c|c|}
\hline & \multirow[b]{2}{*}{$\begin{array}{l}\text { Elementos do } \\
\text { Serviço de } \\
\text { Transportes }\end{array}$} & \multicolumn{6}{|c|}{$\begin{array}{c}\text { Qual empresa é responsável por escolher como os elementos do } \\
\text { serviço serão desenvolvidos e/ou executados? }\end{array}$} \\
\hline & & $\begin{array}{l}\text { Indú } \\
\text { stria } \\
\text { Far } \\
\text { macê } \\
\text { utica } \\
\end{array}$ & $\begin{array}{l}\text { Oper } \\
\text { ador } \\
\text { Logís } \\
\text { tico }\end{array}$ & $\begin{array}{c}\text { Transpota } \\
\text { dor coleta } \\
\text { e } 1^{\mathrm{a}} \\
\text { Transferê } \\
\text { ncia }\end{array}$ & $\begin{array}{l}\text { Transport } \\
\text { ador } \\
\text { Entrega } \\
\text { Final }\end{array}$ & $\begin{array}{l}\text { Cliente final } \\
\text { (distribuidores } \\
\text {, drogarias, } \\
\text { governo, } \\
\text { pessoas físicas) } \\
\end{array}$ & $\begin{array}{c}\text { Outros } \\
\text { (Gover } \\
\text { no, } \\
\text { Anvisa) }\end{array}$ \\
\hline 1 & $\begin{array}{l}\text { Veículo (marca, } \\
\text { ano, modelo, } \\
\text { manutenção) }\end{array}$ & & & & & & \\
\hline 2 & Horário de Coleta & & & & & & \\
\hline 3 & Horário de Entrega & & & & & & \\
\hline 4 & $\begin{array}{l}\text { Horário de } \\
\text { viagem/manuseio }\end{array}$ & & & & & & \\
\hline 5 & $\begin{array}{l}\text { Contratação de } \\
\text { fornecedores na } \\
\text { ponta }\end{array}$ & & & & & & \\
\hline 6 & $\begin{array}{l}\text { Preparação da carga } \\
\text { no veículo } \\
\text { (paletização, } \\
\text { mistura de cargas } \\
\text { diferentes e outros)? }\end{array}$ & & & & & & \\
\hline 7 & $\begin{array}{l}\text { Contratação dos } \\
\text { motoristas dos seus } \\
\text { fornecedores diretos } \\
\text { (perfil) }\end{array}$ & & & & & & \\
\hline 8 & $\begin{array}{l}\text { Contratação dos } \\
\text { motoristas dos seus } \\
\text { fornecedores } \\
\text { Indiretos }\end{array}$ & & & & & & \\
\hline
\end{tabular}




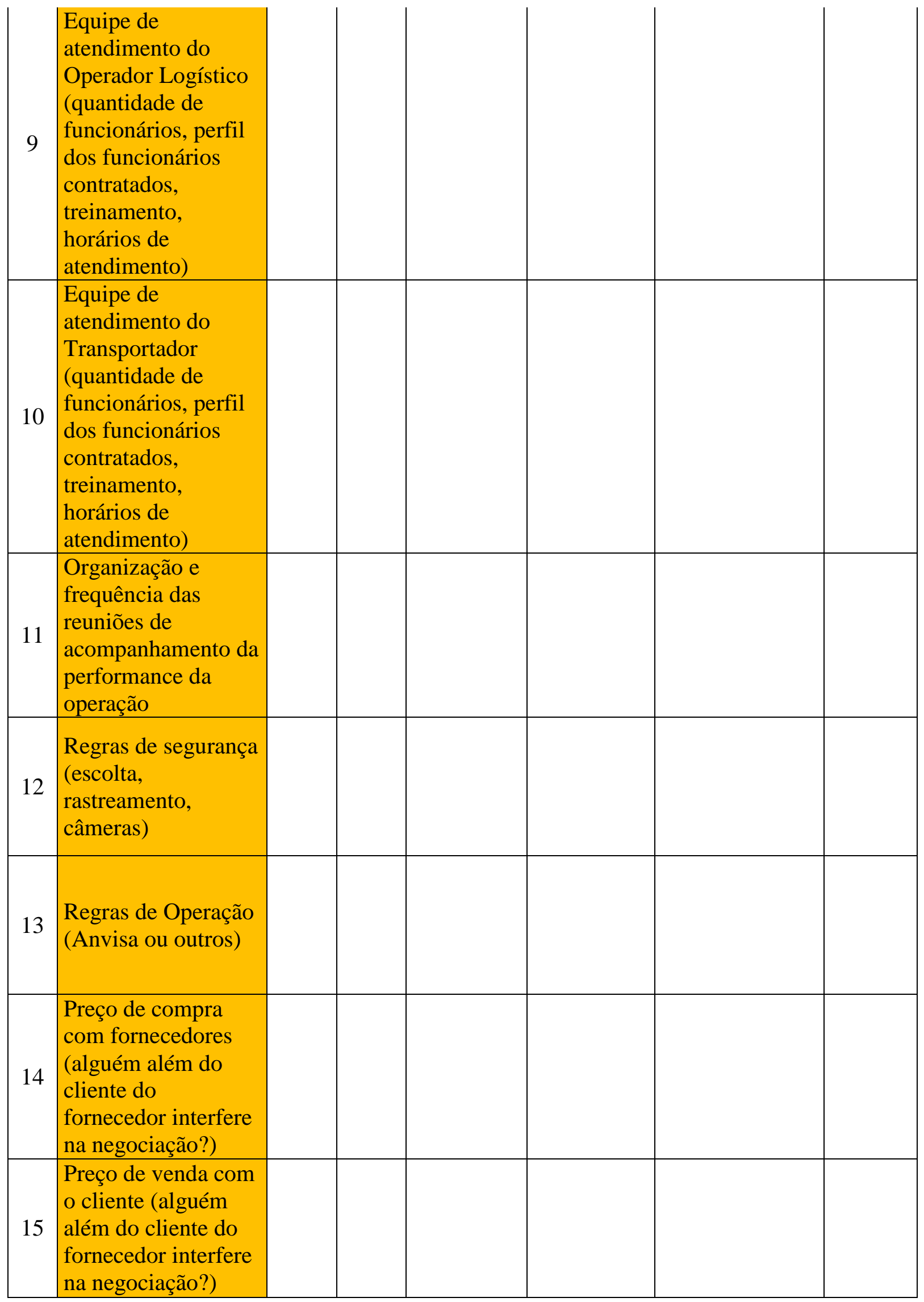




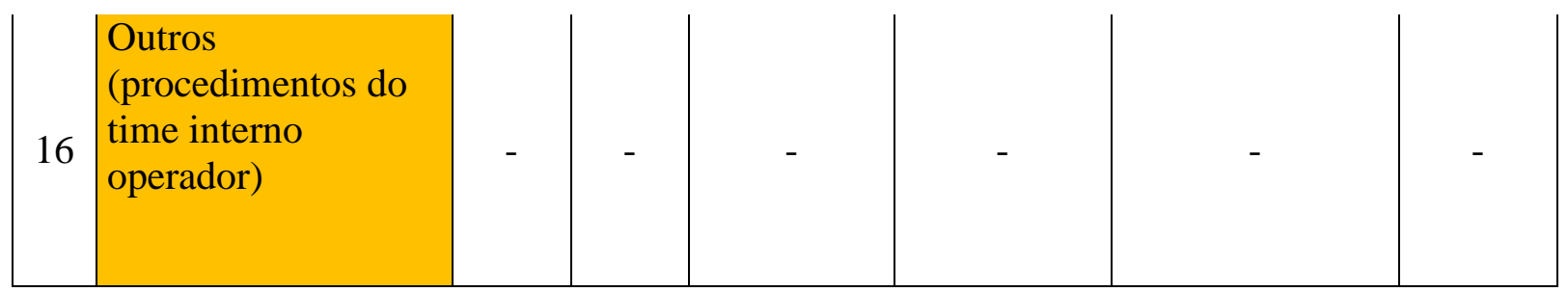

No questionário, tabela 8, constam elementos básicos do serviço de transporte de distribuição de produtos acabados. Ele foi criado por especialistas com mais de dez anos na compra de transportes. Por meio dele, foi possível avaliar quem são os agentes com mais autonomia na cadeia e quem são os responsáveis por definirem mais elementos, ou seja, possuem maior autonomia e maior concentração de poder (centralização). Para preencher este questionário foi pedido aos entrevistados que marcassem com um " $\mathrm{X}$ " para identificar quais eram os agentes responsáveis por tomar decisão sobre aquele elemento do serviço de transportes.

\subsection{Análise de Dados}

Miles e Huberman (1994) comentam também sobre formas de análise intrínseca de um caso, com o propósito de explorar e descrever o objeto. Estes métodos podem ser feitos durante a coleta ou depois. A ideia é que o pesquisador saia de um primeiro entendimento do objeto como uma história contada, para um nível mais alto de abstração, na qual ele possa dissecar essa história, por exemplo, entre variáveis e contexto. Miles e Huberman (1994) trabalham com o conceito de display. Este é definido como um formato visual que apresenta informações de forma sistemática, de tal forma que possam ser tiradas conclusões e ser tomadas ações.

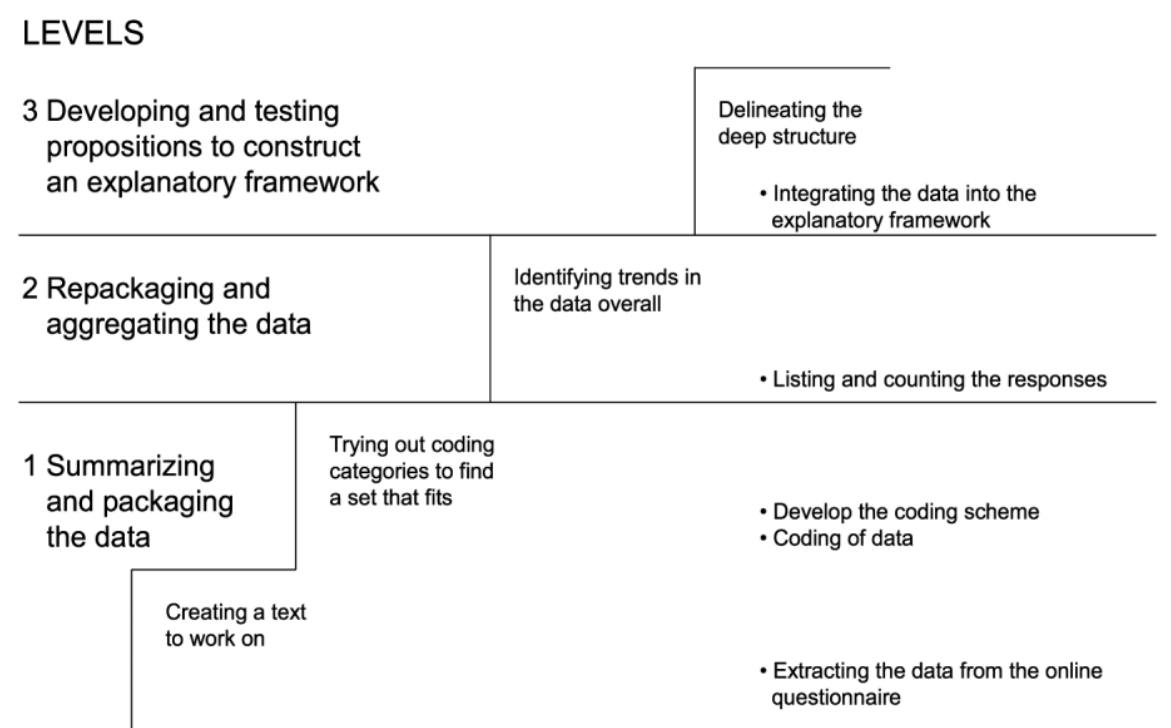

Ilustração 14: Escada da Abstração

Fonte: Miles e Huberman (1994), citando Carney (1990)

Após as análises intrínsecas dos casos, é necessário avaliar o conjunto dos casos, por meio da análise cruzada dos casos. Segundo Miles e Huberman (1994), esta proporciona um mais profundo entendimento e explicação do fenômeno. Estes autores propõem que a etapa de cruzamento seja feita de duas formas distintas: 
- Orientada a Casos: é adequada para encontrar padrões concretos e específicos, porém muito particulares, que dificultam a generalização. Este método avalia se o padrão encontrado na análise intrínseca de um caso pode ser encontrado nos casos seguintes, analisando estes um por um. Este será o caminho escolhido para este projeto de pesquisa.

- Orientada a Variáveis: auxilia no encontro de relações probabilísticas entre variáveis, entretanto não lida com a complexidade real e pode levar a descobertas muito genéricas. Diferente da análise cruzada orientada a casos, esta se baseia em atentar-se aos temas que irão emergir quando todos os casos são comparados, temas os quais talvez não apareçam na análise intrínseca do caso.

Creswell (2007) define outros seis passos para a análise qualitativa dos dados:

1. Organizar e preparar os dados para análise: transcrever as entrevistas e organizá-las.

2. Obter um sentido geral e refletir sobre o contexto global: disponibilidade de tempo dos entrevistados e a sua vontade em participar da entrevista.

3. Começar uma análise detalhada com um processo de codificação: listar todos os temas abordados pelos entrevistados; identificar com códigos cada um dos trechos das entrevistas.

4. Usar o processo de codificação para gerar uma descrição do cenário ou das pessoas além das categorias ou dos temas para análise: agrupar os trechos por assunto.

5. Prever como a descrição e os temas serão representados na narrativa qualitativa: montar um quadro comparativo.

6. Fazer uma interpretação ou extrair significado dos dados: reflexão e contraste com teorias (nível de intangibilidade dos serviços de transportes versus complexidade e necessidade de interação do cliente no processo).

Neste trabalho, foi feita uma adaptação de Creswell (2007) e Miles e Huberman (1994) para analisar os dados dos casos, primeiramente por meio da análise intrínseca de cada entrevista e, posteriormente, a análise cruzada entre as entrevistas, confrontando, por exemplo, as opiniões dos dois lados de um relacionamento na cadeia.

\subsection{Critérios de validação da qualidade}

Yin (2010) propõe técnicas para avaliar a qualidade da pesquisa:

- Validade do Constructo: encontrar as medidas corretas para os conceitos em estudo. $\mathrm{O}$ uso de múltiplas fontes de evidência proporciona esta validade.

- Validade Interna: procurar diminuir as intervenções do pesquisador; esta é aplicável sobre estudos de casos que pretendem estabelecer relações de causa e efeito.

- Validade Externa: esta trata da propriedade de generalização dos achados do estudo. Nestes casos, se houver um grande número de casos, as chances de proporcionar uma generalização é maior.

- Confiabilidade: este parâmetro diz respeito à capacidade de reprodução do estudo com a ocorrência dos mesmos resultados; para tanto, é necessário que 
todos os processos sejam corretamente seguidos e que também estes sejam bem descritos e explícitos. 


\section{Coleta de Dados}

\subsection{A Escolha do Caso}

O caso escolhido foi uma cadeia de serviços logísticos que atue à jusante na distribuição de medicamentos. A escolha deste caso é justificada porque cadeias de serviços é um tema carente de estudos, conforme Akkermans e Voss (2013), Giannakis e Croom (2004) e Giannakis (2011) apontam. De acordo com Tukker (2004), alguns serviços apresentam processos mais tangíveis, como os serviços de logística. Esta característica permite uma maior objetividade nas entrevistas, porque são passíveis de medições e metas pelas empresas.

Estudar cadeias à jusante é justificável pois, conforme Cirtita e Glaser-Segura (2012), este é um tema de muita importância e pouco explorado pela academia. O fato de ser uma cadeia da indústria farmacêutica é vantajoso, pois este é um setor reconhecido pela sua rigorosa regulamentação e controle, variáveis que possivelmente impactam no comportamento da cadeia e podem ser observados em sua estrutura, por exemplo, na dimensão formalização.

A ilustração 15 abaixo representa toda a cadeia que envolve a Indústria Farmacêutica, chamada pelo nome fictício de Cialab, para não revelar sua identidade, conforme pedido de confidencialidade. 


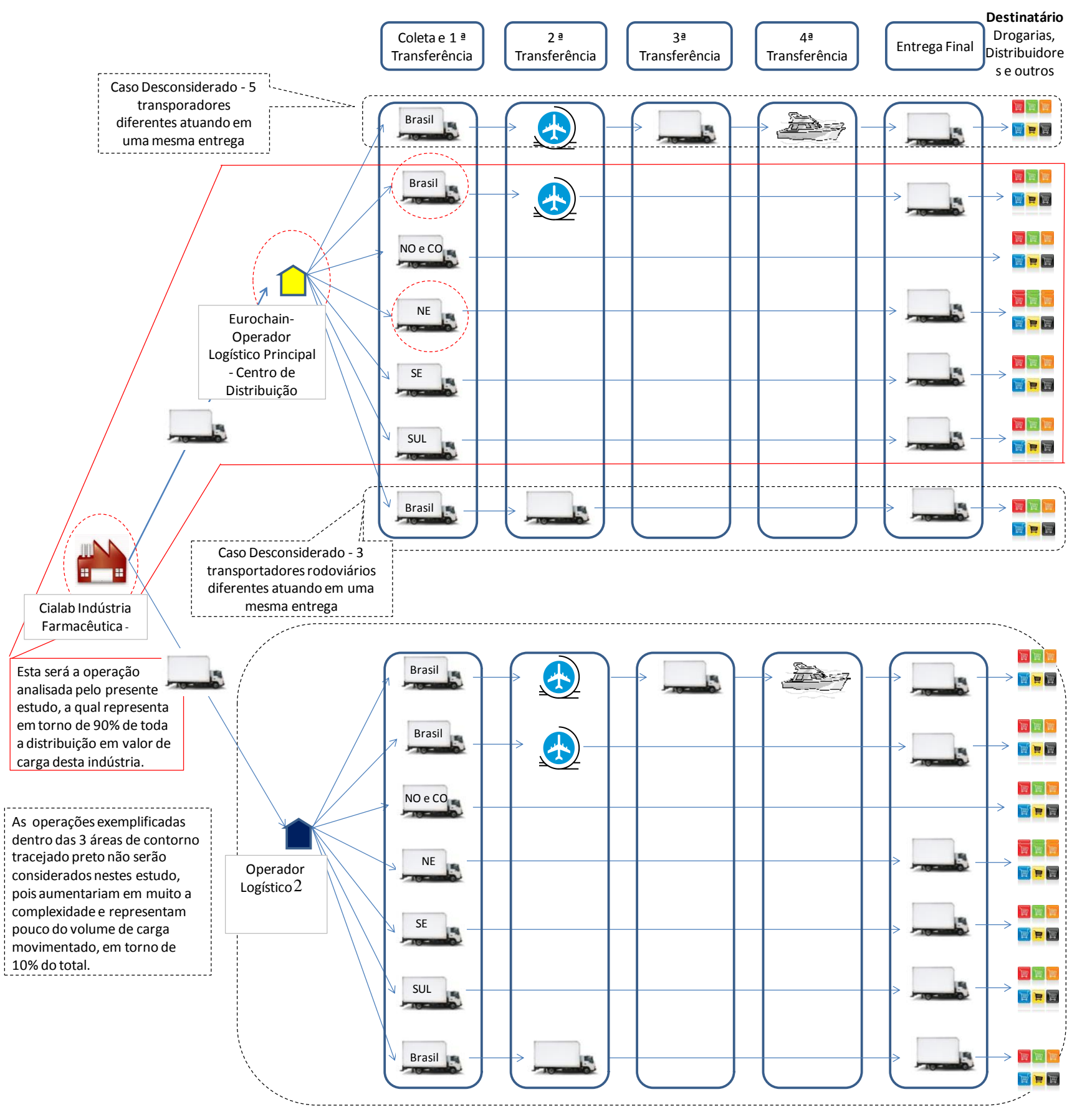

Ilustração 15: Limitação da Cadeia a ser estudada 


\subsection{Matriz de Coleta de Dados}

Cada dimensão terá algumas fontes principais de dados; a tabela 9, a seguir, mostra a relação das dimensões e suas fontes de dados.

Tabela 9: Matriz de coleta de dados para cada dimensão

\begin{tabular}{|c|c|}
\hline Dimensão & Coleta de dados \\
\hline Centralização & $\begin{array}{c}\text { Entrevistas e questionário } \\
\text { sobre autonomia para } \\
\text { execução }\end{array}$ \\
\hline Formalização & $\begin{array}{c}\text { Entrevistas e análise } \\
\text { documental }\end{array}$ \\
\hline Complexidade & $\begin{array}{c}\text { Mapa da cadeia (criado com } \\
\text { base nas entrevistas) }\end{array}$ \\
\hline Integração & Entrevistas \\
\hline
\end{tabular}

\subsection{Entrevistas}

Para este projeto, foi escolhida uma cadeia de distribuição de medicamentos, conforme proposto na metodologia foram entrevistadas quatro empresas, em seis entrevistas.

Tabela 10: Entrevistas realizadas

\begin{tabular}{|c||c|c|}
\hline Entrevista & Empresa & Duração em min \\
\hline 1 & Eurochain & 125 \\
\hline 2 & Cialab & 120 \\
\hline 3 & Eurochain & 190 \\
\hline 4 & Sul Deste Cargo & $\begin{array}{c}210^{*} \text { - houveram } \\
\text { muitas interrupções }\end{array}$ \\
\hline 5 & Air Cargo & 195 \\
\hline 6 & Eurochain & 70 \\
\hline
\end{tabular}


Tabela 11: Visitas realizadas

\begin{tabular}{|c|c|}
\hline Visitas & Empresa \\
\hline $1 \begin{array}{c}\text { Gerente Geral da Unidade de } \\
\text { São Paulo }\end{array}$ & Sul Deste Cargo \\
\hline 2 & Air Cargo \\
\hline $\begin{array}{c}\text { Gerente da Operacional } \\
\text { Farmaceutica }\end{array}$ & Eurochain \\
\hline $\begin{array}{c}\text { Supervisor de Operação de } \\
\text { Armazenagem Farmacêutico }\end{array}$ & \\
\hline
\end{tabular}

Além das visitas aos armazéns e as entrevistas, também foram analisados documentos disponibilizados pelos entrevistados e estes serão detalhados nas análises dos dados. Dúvidas posteriores às entrevistas foram tiradas por meio de telefonemas. 


\section{ANÁLISE DE DADOS}

\subsection{Análise de Dados}

Após a coleta dos dados, todas as entrevistas foram transcritas e se encontram integralmente nos anexos.

\subsection{Breve explicação da operação de distribuição}

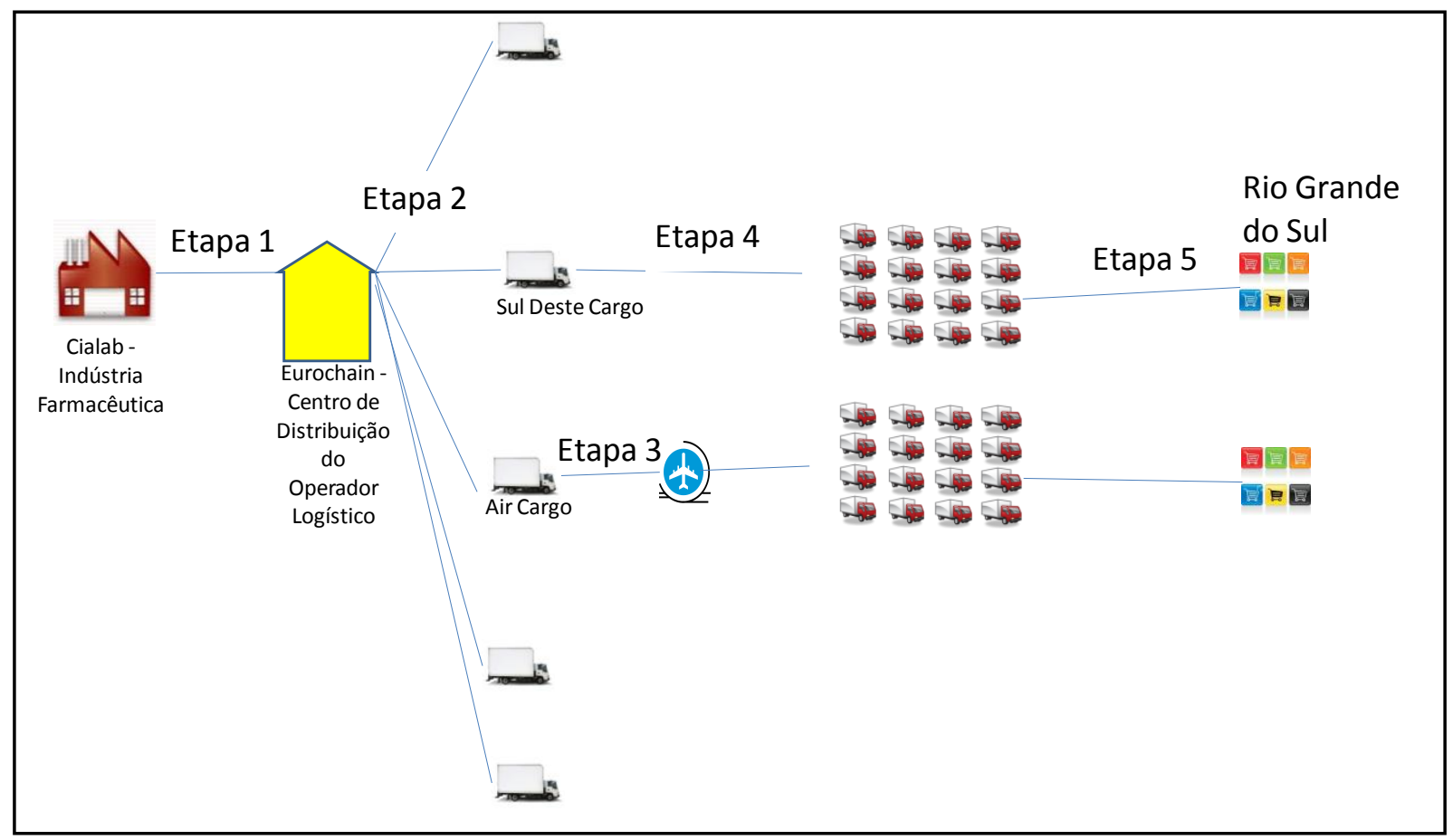

\section{Ilustração 16: Exemplo didático da Cadeia Simplificada}

A Cialab (indústria farmacêutica) terceirizou toda a sua gestão logística para a Eurochain (operador logístico). Assim, a Eurochain é responsável por todo o serviço de armazenagem e distribuição de produtos acabados (medicamentos). Por esta cadeia, são distribuídos mais de R 1 bilhão por ano em remédios. A Eurochain segue uma estratégia de custos variáveis, na qual compra o mínimo possível de ativos, por isso a Eurochain não possui frota própria e sim subcontrata transportadores para todas as atividades.

A seguir, serão explicadas cada uma das etapas demonstradas na Ilustração 16, acima:

- Etapa 1: a Cialab que contratou a Eurochain e transfere sua produção das fábricas para o centro de distribuição da Eurochain.

- Etapa 2: a Eurochain contratou muitos transportadores para distribuir toda a carga Cialab por todo o Brasil. Conforme a Cialab efetua as suas vendas e emite as Notas Fiscais, são emitidas 10 mil Notas Fiscais por mês, o armazém da Eurochain faz a separação dos pedidos conforme as Notas Fiscais e os transportadores responsáveis pelas respectivas regiões das Notas Fiscais vão ao centro de distribuição coletar as suas cargas. 
- Etapa 3: no caso de uma empresa que atue no transporte aéreo, ele possui ainda uma etapa a mais; nesta, uma companhia aérea é responsável pelo transporte da carga até o estado de destino.

- Etapa 4: é muito comum que o transportador que foi subcontratado pela Eurochain também utilize os serviços de um terceiro para ajudá-lo na distribuição das cargas no destino final.

- Etapa 5: nesta etapa, o transportador que foi terceirizado coleta a carga no transportador que foi contratado pela Eurochain e faz a entrega ao destinatário final. O perfil do destinatário da Cialab é o de grandes redes de farmácias ou grandes distribuidores que irão revender para as pequenas farmácias.

- Exemplo Completo: a Cialab já enviou toda a sua produção para o centro de distribuição da Eurochain. A Cialab vendeu R\$300 mil em medicamentos para um grande distribuidor no Rio Grande do Sul - o modal escolhido será rodoviário. Como o destino é no Rio Grande do Sul, a transportadora "Sul Deste Cargo" é quem foi chamada para realizar o serviço. Esta transportadora coleta a carga e leva até o estado do Rio Grande do Sul. Entretanto, esta transportadora não possui volume suficiente para fazer a distribuição no interior do estado, onde fica localizado o grande distribuidor. Por isso, a "Sul Deste Cargo" irá subcontratar outra transportadora (veículo vermelho na ilustração 16), que irá fazer a entrega final para o grande distribuidor no interior do estado.

\subsection{Caracterização das Empresas}

Tabela 12: Breve descrição das empresas

\begin{tabular}{|c|c|c|c|c|}
\hline & $\begin{array}{c}\text { Faturamento } \\
\text { Anual no Brasil }\end{array}$ & $\begin{array}{c}\text { Principais } \\
\text { Serviços/Produt } \\
\text { os }\end{array}$ & Matriz & Outros \\
\hline Cialab & $\begin{array}{c}\text { Mais de } \\
\text { R\$ } 1 \text { bilhão }\end{array}$ & Medicamentos & $\begin{array}{l}\text { Localizada } \\
\text { em uma das } \\
20 \text { maiores } \\
\text { economias } \\
\text { mundiais. }\end{array}$ & $\begin{array}{c}\text { Mais de mil } \\
\text { funcionários, entre as } \\
30 \text { maiores indústrias } \\
\text { farmacêuticas do } \\
\text { Mundo }\end{array}$ \\
\hline Eurochain & $\begin{array}{c}\text { Mais de } \mathrm{R} \$ 300 \\
\text { milhões } \\
\text { (transportes, } \\
\text { sem armazenagem) }\end{array}$ & $\begin{array}{l}\text { Gestão Logística } \\
\text { completa, } \\
\text { armazenagem, } \\
\text { distribuição e } \\
\text { projetos } \\
\end{array}$ & Europa & $\begin{array}{l}\text { Presente em mais de } \\
50 \text { países, entre os } 20 \\
\text { maiores operadores } \\
\text { logísticos do mundo }\end{array}$ \\
\hline Air Cargo & $\mathrm{R} \$ 200$ milhões & $\begin{array}{l}\text { Transporte } \\
\text { Aéreo }\end{array}$ & Brasil & $\begin{array}{c}500 \text { funcionários em } \\
\text { todo o Brasil }\end{array}$ \\
\hline Sul Deste Cargo & $\mathrm{R} \$ 250$ milhões & $\begin{array}{l}\text { Transporte } \\
\text { rodoviário }\end{array}$ & Brasil & $\begin{array}{l}\text { Mais de } 1.300 \\
\text { funcionários }\end{array}$ \\
\hline
\end{tabular}

\subsubsection{Caracterização da Cialab}

A Cialab é uma Indústria Farmacêutica multinacional presente em mais de 30 países, fundada há mais de cinquenta anos, presente no Brasil há mais de cinquenta anos. Fatura mais de US\$ 10 bilhões por ano; no Brasil fatura mais de R\$ 1 bilhão. Em faturamento, a Cialab se 
encontra na lista das trinta maiores indústrias farmacêuticas do mundo. Possuem mais de mil funcionários no Brasil e mais de 10 mil no mundo.

Em todas as operações logísticas de distribuição no Brasil são gastos mais de R $\$ 10$ milhões por ano. Para executar a distribuição de seus produtos acabados, utilizam dois operadores logísticos. Um deles, com a operação menor - trezentas posições pallet no armazém - é responsável pelos produtos de amostra grátis. O outro operador é a Eurochain, responsável por armazenar, customizar e entregar todos os produtos acabados no Brasil - com exceção das amostras grátis. Esta operação ocupa seis mil posições pallets.

A produção da Cialab é feita por diversas fábricas próprias no mundo e algumas produções são terceirizadas. Dos produtos vendidos no Brasil, $40 \%$ é produzido aqui por fábricas próprias e de terceiros; os outros $60 \%$ são produtos importados. Os únicos serviços de transportes não executados pelos operadores logísticos são a exportação e a entrega de matéria-prima das fábricas.

Os clientes da Cialab são grandes distribuidores de medicamentos, grandes redes de farmácias e o governo (Ministério da Saúde e Secretarias). De todos os clientes, treze são considerados principais - representam $75 \%$ do faturamento da Cialab -, nove são grandes distribuidores e quatro são grandes redes de farmácias.

O contato com os clientes é feito essencialmente pela área comercial e as áreas operacionais também se conversam.

A área operacional, juntamente com a área de compras da Cialab, são os principais pontos de contato com os fornecedores - neste caso, o operador logístico Eurochain. A parceria Eurochain e Cialab já dura mais de dez anos. Há alguns anos atrás, a Cialab comprou uma indústria farmacêutica e houve grande aumento de volume para a Eurochain. O histórico comercial tem sido bom, mas em 2013 ocorreram grandes dificuldades operacionais internas na Eurochain.

\subsubsection{Caracterização da Eurochain}

A Eurochain é um operador logístico presente em mais de 50 países e é considerado um dos vinte maiores operadores logísticos no mundo e no Brasil, também. Sua matriz fica na Europa. A Eurochain está há mais de dez anos no Brasil.

$\mathrm{Na}$ operação de transportes no setor farmacêutico, existem cinquenta funcionários; o total em transportes é de seiscentas pessoas e, em todo o Brasil, é de mais de dois mil funcionários. O faturamento da Eurochain, em transportes no setor farmacêutico, gira em torno de $\mathrm{R} \$ 150$ milhões por ano - o setor de transportes em geral fatura mais de $\mathrm{R} \$ 300$ milhões. O gasto em compra de transportes é de mais de R $\$ 200$ milhões.

A Eurochain vende diversos serviços, entre eles: armazenagem, transportes (aéreo, rodoviário, lotação, fracionado, Milk-run, dedicado, aéreo expresso, fretamento de aeronave), gerenciamento do transporte (sistema de informações e indicadores gerenciais), rastreamento da carga, gerenciamento de risco, controle de canhotos da nota fiscal, projetos de otimização, bem como uma consultoria, seguro e recebimento de matéria-prima. 
O setor de transportes deste operador logístico possui, ao todo, sessenta clientes, porém não possuem veículos. Para atender os clientes, são contratados em torno de oitenta fornecedores de transportes. Para o cliente Cialab, a Eurochain contrata diretamente treze fornecedores.

As áreas responsáveis pelo contato com o cliente são: Desenvolvimento de Negócios (área que cria a proposta para participar da concorrência ou "BID"), Gerência de Contas (área responsável por acompanhar questões contratuais e novas demandas de clientes atuais) e Operacional (controla todo o dia a dia da operação e passa informações, trabalho em muita proximidade com o cliente, além disso, a área operacional também participa das propostas e das novas negociações com clientes atuais). As áreas que possuem contato com os fornecedores são a área de Compras (busca fornecedores no mercado e negocia preços) e a área Operacional (faz a integração do fornecedor e o acompanhamento dia-a-dia).

A Cialab representa em torno de $25 \%$ do faturamento de transportes do setor farmacêutico da Eurochain. Essa parceria existe há mais de dez anos. Os treze primeiros anos foram tranquilos, com ótimo nível de serviço e boa lucratividade. Mas a Cialab tem se tornado cada vez mais exigente e houve alterações de contrato e níveis de serviço. Atualmente, em média, a Cialab emite mais de mil Notas Fiscais por mês.

\subsubsection{Caracterização da Air Cargo}

O faturamento anual da Air Cargo é em torno de R $\$ 200$ milhões, sendo que $\mathrm{R} \$ 48$ milhões são oriundos do setor farmacêutico, o qual começou na Air Cargo no ano de 2010. A Eurochain representa $40 \%$ do faturamento de toda a empresa - do setor farmacêutico, ela representa $90 \%$.

São gastos R $\$ 36$ milhões por ano no aéreo e R \$ 30 milhões estão concentrados em uma companhia aérea.

A Air Cargo vende transporte rodoviário e aéreo e todo o acompanhamento da entrega em um único serviço. No caso da Eurochain, eles apenas compram o serviço aéreo. Eles possuem quatro companhias aéreas e mais trinta e cinco empresas parceiras que trabalham na distribuição das cargas das trinta e cinco bases da Air Cargo até o destinatário final.

As áreas comercial e operacional são responsáveis pela comunicação com o cliente Eurochain, com informações de entregas e pendências.

Os fornecedores da Air Cargo possuem um ponto de contato, que é a área operacional, tanto para discussão da operação quanto para discussão de preços.

O faturamento da Air Cargo com a conta da Eurochain é de mais de R $\$ 20$ milhões por ano; só de farmacêutico é de mais de R \$ 10 milhões por ano. Possui quinhentos funcionários em todo o Brasil.

\subsubsection{Caracterização da Sul Deste Cargo}

A Sul Deste Cargo é uma transportadora que está no mercado há mais de sessenta anos, atua com cargas de diversas indústrias, farmacêutica, eletrônicos, alimentícia, autopeças 
e outras. Eles vendem transporte rodoviário, aéreo e armazenagem e atendem as regiões Sul e Sudeste do País. Possui mais de mil e trezentos funcionários no Brasil. O faturamento anual é de $\mathrm{R} \$ 250$ milhões, sendo $\mathrm{R} \$ 180$ milhões oriundos do transporte rodoviário. $\mathrm{R} \$ 54$ milhões é o valor do faturamento do transporte rodoviário voltado para a indústria farmacêutica. Desses R \$ 54 milhões, R\$ 16 milhões são referentes à conta da Eurochain, com dezenove indústrias farmacêuticas.

A empresa em geral possui quinhentos clientes e vinte e um fornecedores. Ela opera quatorze unidades próprias no Brasil, possui uma frota própria de quatrocentos veículos e conta com mais seiscentos agregados.

Só na Eurochain são coletados de três a quatro carretas por dia.

\subsection{Estruturação das Análises}

A análise dos dados foi divida em três partes:

1. Análise Intra-Empresa: analisar o que foi dito por cada empresa, com relação às quatro dimensões, e a analisar os dados que cada empresa fornecerá. Estes formarão uma visão parcial de todos os relacionamentos que essa empresa possui, porém somente de seu ponto de vista.

2. Análise Inter-Empresa: cruzar informações, por exemplo, se o operador logístico tem uma visão de seu relacionamento com o transportador. Nesta etapa, esta visão será cruzada com a visão do transportador sobre este mesmo relacionamento e assim teremos um confronto das opiniões dos dois lados da relação.

3. Análise na Cadeia: serão analisadas as quatro dimensões no contexto total da cadeia; assim, será possível entender como estas dimensões variam ao longo da cadeia e comparar a influência de agentes que não estão relacionados diretamente, como os clientes finais.

As dimensões são diferentes com relação ao nível em que se apresentam. A Formalização pode ser compreendida no nível organizacional (intra-empresa); já a Centralização e a Integração são manifestadas no nível relacionamento (inter-empresas); e a Complexidade só pode ser observada no nível Cadeia. O quadro a seguir apresenta esta diferença entre as dimensões: 
Tabela 13: Níveis de análise das dimensões

\begin{tabular}{|c|c|c|c|}
\hline \multirow[b]{2}{*}{ Dimensão } & \multicolumn{3}{|c|}{ Nível da análise } \\
\hline & $\begin{array}{c}\text { Empresa } \\
\bigcirc\end{array}$ & $\begin{array}{c}\text { Relacionamento (díade) } \\
0\end{array}$ & Cadeia \\
\hline Centralização & sem análise & $\begin{array}{l}\text { Análise de } 1 \\
\text { relacionamento entre } 2 \\
\text { empresas. Qual possui } \\
\text { mais poder? }\end{array}$ & $\begin{array}{l}\text { Comparação dos } \\
\text { diversos } \\
\text { relacionamentos. } \\
\text { Quem possui mais } \\
\text { poder? }\end{array}$ \\
\hline Formalização & $\begin{array}{l}\text { A empresa é } \\
\text { formalizada? }\end{array}$ & $\begin{array}{c}\text { Essa formalização é } \\
\text { influenciada pelos seus } \\
\text { clientes ou fornecedores? }\end{array}$ & $\begin{array}{c}\text { Como a formalização } \\
\text { varia ao longo da } \\
\text { cadeia? }\end{array}$ \\
\hline Complexidade & sem análise & $\begin{array}{c}\text { Quem são os } \\
\text { fornecedores? }\end{array}$ & $\begin{array}{c}\text { Quem e quantos são os } \\
\text { agentes da cadeia? }\end{array}$ \\
\hline Integração & sem análise & $\begin{array}{c}\text { Existe algum trabalho em } \\
\text { conjunto entre as } 2 \\
\text { empresas? }\end{array}$ & $\begin{array}{l}\text { Existe algum trabalho } \\
\text { em conjunto entre } \\
\text { empresas da cadeia? }\end{array}$ \\
\hline $\begin{array}{c}\text { Análises que } \\
\text { fornecerão as } \\
\text { informações }\end{array}$ & - análise intra-empresa & $\begin{array}{c}\text { - análise intra-empresa } \\
+ \\
\text { - análise inter-empresa }\end{array}$ & $\begin{array}{c}\text { - análise intra- } \\
\text { empresa } \\
+ \\
\text { - análise inter- } \\
\text { empresa } \\
+ \\
\text { - análise da cadeia }\end{array}$ \\
\hline
\end{tabular}

Na ilustração 17 seguinte, é demonstrado como os dados gerados na análise IntraEmpresa serão cruzados na análise Inter-Empresas e, depois, agrupados todos na análise da Cadeia. 
Resulta em informações

Resulta em informaç̃̃es CARGO

Entrevista com AIR CARGO

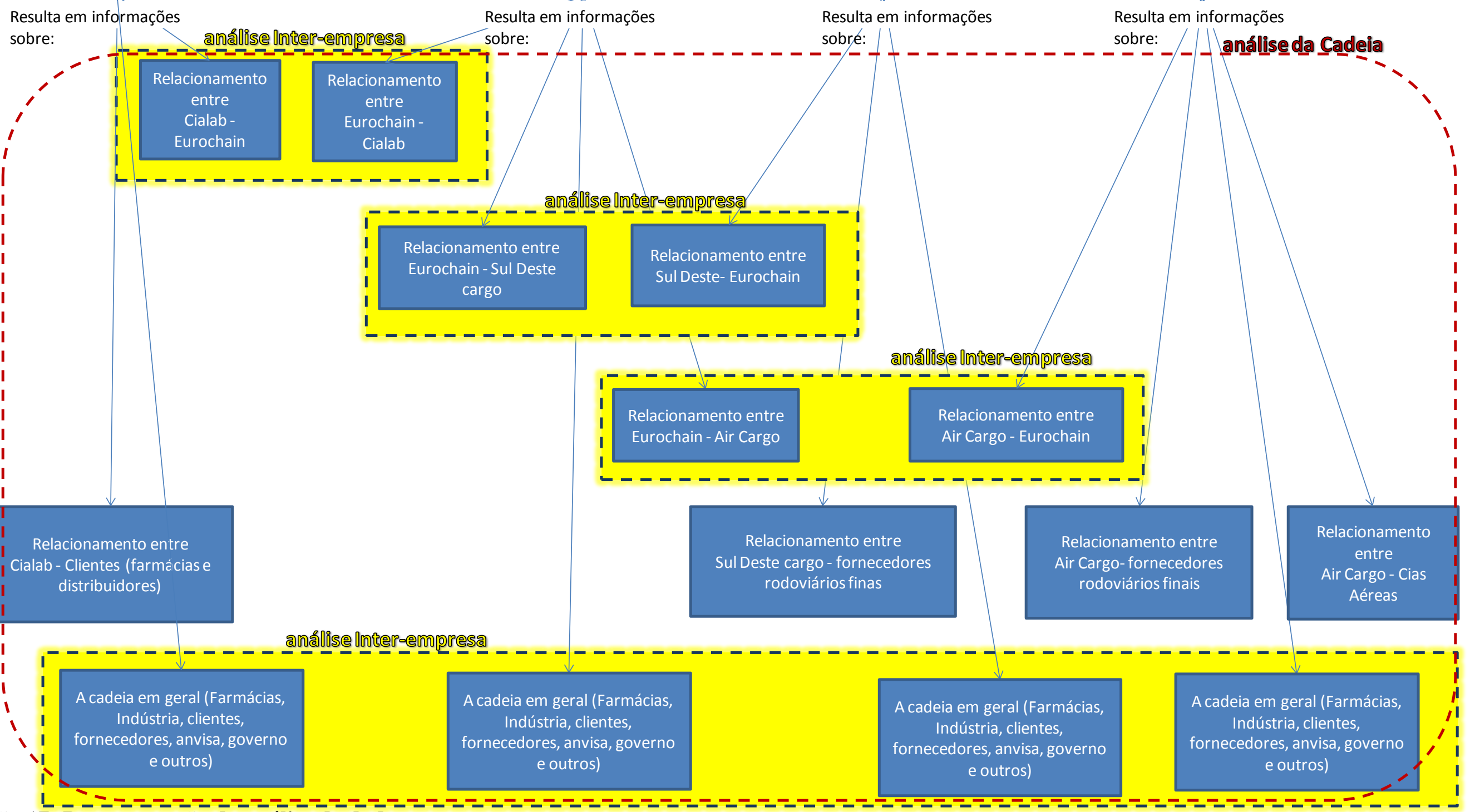




\subsection{Critérios de análise para cada dimensão}

Para poder analisar cada dimensão, foram determinados critérios de avaliação, levando em consideração a teoria e o caso escolhido. A seguir, serão expostos quatro quadros, um para cada dimensão, com os seus respectivos critérios:

\section{Tabela 14: Critérios de análise da Centralização}

\begin{tabular}{|c|c|c|c|}
\hline \multicolumn{4}{|c|}{$\begin{array}{l}\text { É a distribuição ou concentração de poder e autoridade para a tomada de decisão ao longo da } \\
\text { cadeia. Por exemplo, se a indústria interfere somente na camada de fornecedores contratados } \\
\text { diretamente, a cadeia é descentralizada, porém, conforme a sua autoridade atinge outras } \\
\text { camadas, a Centralização é considerada maior (KIM, 2006) (CHOI E HONG, 2002). }\end{array}$} \\
\hline Critérios & Significado & $\begin{array}{l}\text { Exemplos de } \\
\text { Evidências }\end{array}$ & $\begin{array}{l}\text { Coleta de } \\
\text { Dados }\end{array}$ \\
\hline Negociações & $\begin{array}{l}\text { Um dos aspectos da centralização diz } \\
\text { respeito à concentração de poder. O } \\
\text { poder é manifestado em } \\
\text { relacionamentos, assim identificar se } \\
\text { existe um vencedor com mais } \\
\text { frequência nas disputas de maior } \\
\text { importância indica alguma } \\
\text { concentração de poder }\end{array}$ & $\begin{array}{l}\text { Quem é o vencedor nas } \\
\text { negociações de preços e } \\
\text { de outras demandas? }\end{array}$ & Entrevistas \\
\hline Autonomia & $\begin{array}{l}\text { A centralização é baseada na } \\
\text { concentração de tomadas de } \\
\text { decisões. Assim, é imprescindível } \\
\text { verificar quem são os responsáveis } \\
\text { pela definição de elementos básicos } \\
\text { da atividade de transportes }\end{array}$ & $\begin{array}{l}\text { Identificar se algum dos } \\
\text { agentes da cadeia é } \\
\text { responsável por } \\
\text { determinar diversos } \\
\text { elementos básicos da } \\
\text { atividade de transporte }\end{array}$ & $\begin{array}{l}\text { Questionário } \\
\text { estruturado }\end{array}$ \\
\hline $\begin{array}{l}\text { Contexto } \\
\text { (aplicado a } \\
\text { todas as } \\
\text { dimensões) }\end{array}$ & $\begin{array}{l}\text { Informações diretas ou indiretas que } \\
\text { reforcem ou questionem os outros } \\
\text { critérios. Informações sobre o } \\
\text { ambiente, sobre a segurança, } \\
\text { histórico de relacionamento, } \\
\text { mercado, a empresa no geral e outros }\end{array}$ & $\begin{array}{c}\text { Entrevistas, } \\
\text { Questionários, Visita e } \\
\text { Documentos }\end{array}$ & $\begin{array}{l}\text { Entrevistas, } \\
\text { visitas e } \\
\text { documentos. }\end{array}$ \\
\hline $\begin{array}{l}\text { *Importância } \\
\text { de uma } \\
\text { empresa para } \\
\text { a outra }\end{array}$ & $\begin{array}{l}\text { Considerando duas empresas, A que } \\
\text { fornece para B, se A for muito } \\
\text { importante para B e B for pouco } \\
\text { importante para A, temos uma } \\
\text { indicação de que A terá mais poder } \\
\text { nas negociações }\end{array}$ & $\begin{array}{l}\text { Importância estratégica } \\
\text { (quer entrar em um novo } \\
\text { mercado, ausência de } \\
\text { outros fornecedores, alta } \\
\text { demanda) }\end{array}$ & Entrevistas \\
\hline $\begin{array}{l}\text { *Participaçã } \\
\text { o no } \\
\text { faturamento }\end{array}$ & $\begin{array}{l}\text { Para um fornecedor, uma empresa } \\
\text { que tenha alta participação de seu } \\
\text { faturamento se torna mais } \\
\text { importante, por isso possui maior } \\
\text { força para negociar }\end{array}$ & $\begin{array}{l}\text { Percentual de participação } \\
\text { que um cliente possui no } \\
\text { total de faturamento do } \\
\text { fornecedor ou vice-versa }\end{array}$ & Entrevistas \\
\hline
\end{tabular}


Tabela 15: Critérios de análise da Formalização

\begin{tabular}{|c|c|c|c|}
\hline \multicolumn{4}{|c|}{$\begin{array}{l}\text { É entendida como a explicitação das regras, procedimentos e valores, independentemente do } \\
\text { fato de estarem escritas ou não, e como essas regras influenciam as tomadas de decisão e } \\
\text { relacionamentos. Esta dimensão será analisada no nível de relacionamentos, fornecedor- } \\
\text { cliente (KIM, 2006) (CHOI E HONG, 2002). }\end{array}$} \\
\hline Critérios & Significado & $\begin{array}{l}\text { Exemplos de } \\
\text { Evidências }\end{array}$ & Coleta de Dados: \\
\hline $\begin{array}{l}\text { Preços definidos } \\
\text { e formalizados? }\end{array}$ & $\begin{array}{l}\text { As negociações se tornam } \\
\text { regras formalizadas para } \\
\text { cobrança }\end{array}$ & $\begin{array}{l}\text { Tabela de } \\
\text { preços }\end{array}$ & Entrevistas, Documentos \\
\hline $\begin{array}{l}\text { Níveis de } \\
\text { serviços estão } \\
\text { acordados e } \\
\text { formalizados? }\end{array}$ & $\begin{array}{l}\text { A qualidade que deverá } \\
\text { ser entregue no serviço } \\
\text { está definida e } \\
\text { formalizada para ambas } \\
\quad \text { as partes }\end{array}$ & $\begin{array}{c}\text { Contrato, anexo } \\
\text { ou ata }\end{array}$ & Entrevistas, Documentos \\
\hline $\begin{array}{c}\text { Acompanhament } \\
\text { o do nível de } \\
\text { serviço? }\end{array}$ & $\begin{array}{l}\text { Existe um processo } \\
\text { formalizado de } \\
\text { acompanhamento da } \\
\text { qualidade da operação }\end{array}$ & $\begin{array}{l}\text { Relatórios de } \\
\text { performance ou } \\
\text { apresentação } \\
\text { com } \\
\text { desempenho }\end{array}$ & Entrevistas, Documentos \\
\hline $\begin{array}{l}\text { Existe uma } \\
\text { prática de } \\
\text { reuniões } \\
\text { operacionais } \\
\text { padrão entre } \\
\text { fornecedor e } \\
\text { cliente? }\end{array}$ & $\begin{array}{l}\text { Existe um procedimento } \\
\text { formal com relação ao } \\
\text { relacionamento das duas } \\
\text { empresas }\end{array}$ & $\begin{array}{c}\text { Atas de } \\
\text { reunião, } \\
\text { cruzamento de } \\
\text { informações } \\
\text { entre empresas } \\
\text { que participam } \\
\text { da mesma } \\
\text { reunião } \\
\end{array}$ & Entrevistas, Documentos \\
\hline $\begin{array}{l}\text { Existem regras } \\
\text { padronizadas } \\
\text { com relação aos } \\
\text { riscos de carga } \\
\text { de alto valor? }\end{array}$ & $\begin{array}{c}\text { Existe um procedimento } \\
\text { operacional formal para } \\
\text { transporte de cargas de } \\
\text { alto valor }\end{array}$ & $\begin{array}{l}\text { Documento, } \\
\text { contrato } \\
\text { seguradora }\end{array}$ & Entrevistas, Documentos \\
\hline $\begin{array}{c}\text { Contexto } \\
\text { (aplicado a todas } \\
\text { as dimensões) }\end{array}$ & $\begin{array}{l}\text { Informações diretas ou } \\
\text { indiretas que reforcem ou } \\
\text { questionem os outros } \\
\text { critérios. Informações } \\
\text { sobre o ambiente, sobre a } \\
\text { segurança, histórico de } \\
\text { relacionamento, mercado, } \\
\text { a empresa no geral e } \\
\text { outros }\end{array}$ & $\begin{array}{l}\text { Entrevistas, } \\
\text { Questionários, } \\
\text { Visita e } \\
\text { Documentos. }\end{array}$ & $\begin{array}{l}\text { Entrevistas, visitas e } \\
\text { documentos }\end{array}$ \\
\hline
\end{tabular}


Tabela 16: Critérios de análise da Complexidade

\begin{tabular}{|c|c|c|c|}
\hline \multicolumn{4}{|c|}{$\begin{array}{l}\text { É o conjunto da diferenciação vertical, horizontal e a dispersão espacial. Na Cadeia de } \\
\text { Suprimentos, a diferenciação vertical se traduz na quantidade de camadas de fornecedores e a } \\
\text { diferenciação horizontal, por sua vez, é quantidade de fornecedores por camada. A Dispersão } \\
\text { Espacial será considerada pela distância geográfica entre os participantes da cadeia (BOYLE, } \\
\text { HUMPHREYS e McIVOR, 2008) (CHOI E HONG, 2002). }\end{array}$} \\
\hline Critérios & Significado & Exemplos de Evidências & $\begin{array}{l}\text { Coleta de } \\
\text { Dados: }\end{array}$ \\
\hline $\begin{array}{l}\text { Diferenciação } \\
\text { Vertical }\end{array}$ & $\begin{array}{l}\text { As negociações se tornam } \\
\text { regras formalizadas para } \\
\text { cobrança }\end{array}$ & $\begin{array}{l}\text { Quantas subcontratações são } \\
\text { necessárias para a entrega de } \\
\text { uma única nota fiscal, quantas } \\
\text { empresas diferentes } \\
\text { participam deste único serviço }\end{array}$ & Entrevistas \\
\hline $\begin{array}{c}\text { Diferenciação } \\
\text { horizontal }\end{array}$ & $\begin{array}{c}\text { A qualidade que deverá ser } \\
\text { entregue no serviço está } \\
\text { definida e formalizada para } \\
\text { ambas as partes }\end{array}$ & $\begin{array}{c}\text { Quantos transportadores } \\
\text { atuam na segunda contratação. } \\
\text { Quantos na terceira e assim } \\
\text { por diante }\end{array}$ & Entrevistas \\
\hline $\begin{array}{l}\text { Dispersão } \\
\text { Espacial }\end{array}$ & $\begin{array}{l}\text { Quanto menor a área de } \\
\text { atuação da cadeia, mais } \\
\text { simples é a sua operação; } \\
\text { por exemplo, atuar em uma } \\
\text { cidade é mais simples que } \\
\text { em um estado, que é mais } \\
\text { simples que um continente }\end{array}$ & $\begin{array}{c}\text { A distância da mais longa } \\
\text { entrega }\end{array}$ & Entrevistas \\
\hline $\begin{array}{l}\text { Quantidade } \\
\text { de modais } \\
\text { utilizados }\end{array}$ & $\begin{array}{l}\text { Quantos mais modais } \\
\text { forem utilizados, mais } \\
\text { conhecimento será } \\
\text { necessário, bem como o } \\
\text { número de fornecedores } \\
\text { aumentará também } \\
\end{array}$ & $\begin{array}{l}\text { Modal rodoviário, aéreo e } \\
\text { hidroviário juntos }\end{array}$ & Entrevistas \\
\hline $\begin{array}{l}\text { Contexto } \\
\text { (aplicado a } \\
\text { todas as } \\
\text { dimensões) }\end{array}$ & $\begin{array}{c}\text { Informações diretas ou } \\
\text { indiretas que reforcem ou } \\
\text { questionem os outros } \\
\text { critérios. Informações sobre } \\
\text { o ambiente, sobre a } \\
\text { segurança, histórico de } \\
\text { relacionamento, mercado, a } \\
\text { empresa no geral e outros }\end{array}$ & $\begin{array}{c}\text { Entrevistas, Questionários, } \\
\text { Visita e Documentos }\end{array}$ & $\begin{array}{l}\text { Entrevistas, } \\
\text { visitas e } \\
\text { documentos. }\end{array}$ \\
\hline
\end{tabular}


Tabela 17: Critérios de análise da Integração

\begin{tabular}{|c|c|c|c|}
\hline \multicolumn{4}{|c|}{$\begin{array}{l}\text { É a colaboração, criação de objetivos em comum e confiança entre empresas que precisam } \\
\text { trabalhar em conjunto. Por exemplo, dois fornecedores que atendem um mesmo cliente e } \\
\text { precisam trabalhar em conjunto, ou então, um fornecedor e o seu cliente (COUGHLAN et al. } \\
\text { 2003). }\end{array}$} \\
\hline Critérios & Significado & Exemplos de Evidências & $\begin{array}{l}\text { Coleta de } \\
\text { Dados: }\end{array}$ \\
\hline $\begin{array}{ll}\text { Iniciativas } & \text { em } \\
\text { conjunto } & \text { que } \\
\text { proporcionem } & \\
\text { benefícios } & \text { para } \\
\text { ambas as empresas }\end{array}$ & $\begin{array}{l}\text { Existe de fato alguma } \\
\text { iniciativa que, baseado na } \\
\text { confiança, boa comunicação } \\
\text { e pensamento colaborativo, } \\
\text { proporcionou ganho para as } \\
\text { duas empresas }\end{array}$ & $\begin{array}{l}\text { Identificar alguma } \\
\text { iniciativa que tenha sido } \\
\text { feita em conjunto e com } \\
\text { ganho para ambos os } \\
\text { lados }\end{array}$ & Entrevistas \\
\hline $\begin{array}{l}\text { Contex to (aplicado a } \\
\text { todas as dimensões) }\end{array}$ & $\mid \begin{array}{llr}\text { Informações } & \text { diretas } & \text { ou } \\
\text { indiretas que } & \text { reforcem } & \text { ou } \\
\text { questionem } & \text { os } & \text { outros } \\
\text { critérios. Informações } & \text { sobre } \\
\text { o ambiente, sobre } & \text { a } \\
\text { segurança, histórico re de } & \text { relacionamento, mercado, a } \\
\text { empresa no geral e outros }\end{array}$ & $\begin{array}{l}\text { Entrevistas, } \\
\text { Questionários, Visita e } \\
\text { Documentos }\end{array}$ & $\begin{array}{l}\text { Entrevistas, } \\
\text { visitas e } \\
\text { documentos }\end{array}$ \\
\hline *Comunicação & \begin{tabular}{|lr} 
Uma boa comunicação, com \\
transparência é essencial \\
para confiança \\
consequentemente, \\
colaboração entre empresas
\end{tabular} & $\begin{array}{l}\text { Existem reuniões } \\
\text { constantemente. Uma } \\
\text { empresa tem acesso e } \\
\text { liberdade outra }\end{array}$ & $\begin{array}{l}\text { Entrevistas } \\
\text { e } \\
\text { documentos }\end{array}$ \\
\hline *Confiança & $\begin{array}{l}\text { Confiança é a base sobre a } \\
\text { qual a Integração cresce }\end{array}$ & $\begin{array}{llr}\text { Existem } & \text { contratos } & \text { com } \\
\text { muitas } & \text { cláusulas } & \text { de } \\
\text { proteção? } & & \\
\end{array}$ & $\begin{array}{l}\text { Entrevistas } \\
\text { e } \\
\text { documentos }\end{array}$ \\
\hline $\begin{array}{l}\text { *Tempo } \\
\text { relacionamento }\end{array}$ & $\begin{array}{l}\text { Relacionamentos de longo } \\
\text { prazo necessitam de práticas } \\
\text { responsáveis por ambas as } \\
\text { partes, que proporcionem } \\
\text { sustentabilidade a parceria; } \\
\text { essas práticas envolvem } \\
\text { relações transparentes e } \\
\begin{array}{lll}\text { justas, pensando ganhos e } \\
\text { dificuldades de ambos os } \\
\text { lados }\end{array}\end{array}$ & $\begin{array}{ll}\text { Há quantos } & \text { anos as } \\
\text { empresas } & \text { trabalham } \\
\text { juntas? } & \end{array}$ & Entrevistas \\
\hline
\end{tabular}




\subsection{Classificação Final dos Critérios}

Cada dimensão possui seis critérios, porém pode ser que dependendo do caso tratado, algum destes critérios perca o sentido ou não possa ser considerado. Assim, esse será marcado como indiferente/desconsiderado. Caso os critérios estejam adequados para a análise, eles poderão possuir três classificações: "confirmar uma dimensão", "negar uma dimensão", ou "estar em equilíbrio", ou seja, nem reforça nem nega a dimensão em questão. Os termos utilizados nas análises em si são específicos para cada análise, para facilitar o entendimento. Por exemplo, na centralização, um dos termos utilizados é "Eurochain concentra mais poder que a Sul Deste Cargo", ao invés do genérico "confirma a dimensão".

Ao final das atribuições de cada critério, será dado o resultado final daquela dimensão, que será a soma dos critérios que reforçam a dimensão. Por exemplo, se considerarmos a dimensão centralização e esta tiver quatro critérios que foram avaliados como "Empresa A concentra mais poder que B", um critério foi desconsiderado e um critério que sobrou apoia a empresa $\mathrm{B}$, assim temos que 4 A x 1B, logo o resultado final é a forte centralização do poder em A.

Tabela 18: Exemplo de classificação final da dimensão

\begin{tabular}{|c|c|c|c|c|c|c|}
\hline $\begin{array}{c}\text { Critérios que } \\
\text { confirmam }\end{array}$ & 6 & 5 & 4 & 3 & 3 & 2 \\
\hline $\begin{array}{c}\text { Critérios que } \\
\text { negam }\end{array}$ & $(0)$ & $(0,1)$ & $(2,1,0)$ & 2 & 1 & 1 \\
\hline Resultado final & Forte & Forte & Forte & Levemente & Forte & Levemente \\
\hline
\end{tabular}

\subsection{Análise Intra-Empresa}

Antes de seguir para as análises, é importante destacar que existe uma legenda para ser possível identificar a origem, entrevistas, documentos ou visitas, dos trechos destacados:

Tabela 19: Legendas para diferenciar trechos oriundos das visitas, documentos e entrevistas

\begin{tabular}{|c|l|}
\hline Símbolo & \multicolumn{1}{c|}{ Significado } \\
\hline “” & Trechos que estão entre aspas são falas dos entrevistados \\
\hline$\rightarrow()$ & $\begin{array}{l}\text { Trechos entre parênteses são esclarecimentos do entrevistador para que a } \\
\text { fala do entrevistado possa ser entendida no seu contexto. }\end{array}$ \\
\hline$*$ & $\begin{array}{l}\text { Setas na frente do texto significam que esses dados foram coletados a } \\
\text { partir das visitas. }\end{array}$ \\
\hline $\begin{array}{c}\text { Questionário } \\
\text { "Autonomia } \\
\text { para execução } \\
\text { do serviço" }\end{array}$ & $\begin{array}{l}\text { Asteriscos na frente significam que a origem destes dados são documentos } \\
\text { fornecidos pelo entrevistado para análise. }\end{array}$ \\
Quando a conclusão vier do Questionário "Autonomia para execução do \\
\hline
\end{tabular}




\subsubsection{Análise intra-empresa Air Cargo}

\subsubsection{Centralização}

\subsection{Relacionamento Air Cargo - Eurochain}

\begin{tabular}{|c|c|c|c|}
\hline Critérios & $\begin{array}{c}\text { Trechos da Entrevista, Visitas e } \\
\text { Documentos }\end{array}$ & Análise & Resultado \\
\hline Negociações & $\begin{array}{l}\text { "Operacionalmente vamos muito bem, } \\
\text { melhorou muito, porém financeiramente não, } \\
\text { a Eurochain nos aperta demais no preço, não } \\
\text { sei de onde eles tiram preços base tão baixos } \\
\text { para negociar." } \\
\text { "A Eurochain impôs que muitos } \\
\text { transportadores teriam que colocar uma } \\
\text { equipe dentro do Centro de Distribuição da } \\
\text { Eurochain para fazer a conferência. Nós } \\
\text { colocamos uma equipe lá de } 8 \text { pessoas com } \\
\text { custo Air Cargo e sem reajuste na tarifa." } \\
\text { "A Eurochain nos aperta financeiramente, } \\
\text { mas confia no nosso serviço." }\end{array}$ & $\begin{array}{l}\text { Por duas vezes durante a } \\
\text { entrevista foi citado a } \\
\text { grande dificuldade que a } \\
\text { Air Cargo possui nas } \\
\text { negociações de preços, ou } \\
\text { seja, eles são a parte mais } \\
\text { fraca na negociação. } \\
\text { Nessa } \\
\text { operacional o custo ficou } \\
\text { para a Air Cargo, foram } \\
\text { mais uma vez mais o lado } \\
\text { frágil. }\end{array}$ & $\begin{array}{c}\text { Eurochain } \\
\text { concentra } \\
\text { mais poder } \\
\text { que Air } \\
\text { Cargo }\end{array}$ \\
\hline Autonomia & $\begin{array}{l}\text { "Hoje a Eurochain é o principal cliente da } \\
\text { Air Cargo, até por acordo comercial não } \\
\text { participamos das concorrências que eles } \\
\text { participam, pedimos autorização para } \\
\text { participar." } \\
\text { Análise do Questionário Autonomia para } \\
\text { Execução do Serviço: A Eurochain permite } \\
\text { que a Air Cargo escolha os próprios } \\
\text { fornecedores, equipe e outros processos. Mas } \\
\text { determina veículos, regras de gerenciamento } \\
\text { de risco, forma de atendimento e pode } \\
\text { influenciar no descadastramento de } \\
\text { fornecedores. (Segundo a Air Cargo, mais } \\
\text { elementos são determinados pelo Operador } \\
\text { Logístico do que por eles próprios). }\end{array}$ & $\begin{array}{l}\text { O processo comercial da } \\
\text { Air Cargo, que é essencial } \\
\text { para o seu crescimento é } \\
\text { limitado pela Eurochain. A } \\
\text { Eurochain possui grande } \\
\text { influência. } \\
\text { O questionário também } \\
\text { mostra a alta influência da } \\
\text { Eurochain nas tomadas de } \\
\text { decisão dos elementos } \\
\text { operacionais. }\end{array}$ & $\begin{array}{c}\text { Eurochain } \\
\text { concentra } \\
\text { mais poder } \\
\text { que Air } \\
\text { Cargo }\end{array}$ \\
\hline
\end{tabular}


*Importância de uma empresa para a outra
"Hoje a Eurochain é o principal cliente da Air Cargo, até por acordo comercial não participamos das concorrências que eles participam, pedimos autorização para participar."

"Sim, tudo é feito a 4 mãos. Porém, creio que isso também tem relação com a nossa importância para eles, pois já trabalhei com a Eurochain por outras empresas, mas não era ouvido nas propostas de melhorias que fiz, hoje sou ouvido nas mesmas propostas." "O faturamento deles (Eurochain) é muito representativo para nós. Nós dentro da empresa, temos a função de manter esta conta, nossa primeira missão aqui é esta. Investimos muito, entramos no mercado a partir de 2011 com todas as licenças necessárias, por isso existe grande expectativa sobre esta conta, principalmente no farmacêutico." "Sim, é uma conta lucrativa." "Em nossa principal companhia aérea somos o maior embarcador de carga. Essa companhia aérea possui um serviço de atendimento especial para as 5 maiores contas deles, no qual nos estamos inclusos, assim, somos atendidos com prioridade." "A empresa antigamente até 2010 trabalhava apenas com transportes de eletrônicos, foi feito um investimento pesado para poderem concorrer no farmacêutico, a grande aposta são as indústrias farmacêuticas da Eurochain."

"Na relação Eurochain conosco é tudo feito a 4 mãos, não é topdown". "Distribuição da carga aérea farmacêutica da Eurochain antes era $60 \%$ para a Air Cargo e $40 \%$ para outros fornecedores, atualmente é $80 \%$ para Air Cargo e $20 \%$ para outros fornecedores."

$\rightarrow$ ( Neste mesmo terreno haviam diversos outros galpões muito grandes, mais de $10 \mathrm{mil}$ $\mathrm{m} 2$ com outros produtos.) "Ainda não é aplicado, mas será em 2015". (Da Eurochain sobre a Air Cargo) "Os requisitos para entrar no setor de farmacêuticos são altos, sabemos de poucas empresas que competem conosco, consigo citar somente 5."
Para a Air Cargo a Eurochain é muito importante estrategicamente para consolidar sua posição no mercado de farmacêutico, além de dar lucro. É uma pressão sobre eles manter essa conta.

A Air Cargo entende que existe um bom relacionamento, que eles são bons fornecedores $\mathrm{e}$ ganharam espaço dentro da Eurochain, detém agora $80 \%$ do frete aéreo deles. Além disso, o mercado é restrito e eles são uma das empresas de transporte aéreo mais importante do país.

A visita mostra que em termos de espaço de armazém a Air Cargo possuiu inúmeros outros clientes mais volumosos.

Para a Eurochain mudar de fornecedor pode ser difícil, mas para a Air Cargo achar outra conta igual é mais difícil.
Eurochain concentra mais poder que Air Cargo 


\begin{tabular}{|c|c|c|c|}
\hline $\begin{array}{l}\text { *Participa- } \\
\text { ção no } \\
\text { faturamen- } \\
\text { to }\end{array}$ & $\begin{array}{l}\text { "A conta toda da Eurochain equivale em } \\
\text { torno de } 40 \% \text { do total do faturamento da } \\
\text { empresa. As contas do farmacêutico da } \\
\text { Eurochain equivalem } 90 \% \text { do nosso } \\
\text { faturamento do setor farmacêutico." } \\
\text { "Com a Eurochain é de R\$ } 80 \text { milhões por } \\
\text { ano, só de farmacêutico temos R } \$ 43 \text { milhões } \\
\text { por ano. Não sei dizer quanto desses R\$43 } \\
\text { milhões é representado pela Cialab." } \\
\text { "Distribuição da carga aérea farmacêutica da } \\
\text { Eurochain antes era } 60 \% \text { para a Air Cargo e } \\
40 \% \text { para outros fornecedores, atualmente é } \\
80 \% \text { para Air Cargo e } 20 \% \text { para outros } \\
\text { fornecedores." }\end{array}$ & $\begin{array}{l}\text { Mesmo a Air Cargo tendo } \\
80 \% \text { do aéreo } r \text { da } \\
\text { Eurochain. O peso da } \\
\text { representatividade na Air } \\
\text { Cargo Farmacêutico é } \\
\text { enorme, a Eurochain é } 90 \% \\
\text { do faturamento da Air } \\
\text { Cargo. Para a Eurochain } \\
\text { mudar de fornecedor pode } \\
\text { ser difícil, mas para a Air } \\
\text { Cargo achar outra conta } \\
\text { igual é mais difícil. }\end{array}$ & $\begin{array}{c}\text { Eurochain } \\
\text { concentra } \\
\text { mais poder } \\
\text { que Air } \\
\text { Cargo }\end{array}$ \\
\hline
\end{tabular}

O critério Contexto não foi apresentado, pois não havia nenhuma informação relevante que não tenha sido discutida nos outros critérios.

Conclusão final: Neste relacionamento a Centralização do poder está fortemente na Eurochain, 4 itens a favor da Eurochain, 0 a favor da Air Cargo. 


\subsection{Relacionamento Air Cargo - Transportadores Rodoviários}

\begin{tabular}{|c|c|c|c|}
\hline Critérios & $\begin{array}{c}\text { Trechos da Entrevista, Visitas e } \\
\text { Documentos }\end{array}$ & Análise & Resultado \\
\hline Negociações & $\begin{array}{l}\text { "Entre nós e os nossos fornecedores tentamos } \\
\text { negociar tudo, porém já cortamos fornecedores } \\
\text { que não quiseram se adequar aos nossos } \\
\text { requisitos, fornecedores que não quiseram } \\
\text { investir em sua estrutura. } \\
\text { " O Laboratório faz muitas exigências de } \\
\text { procedimentos (...), porém em alguns locais } \\
\text { distantes as pessoas estão tão acostumadas a } \\
\text { receberem fora do padrão que nem reclamam } \\
\text { com o laboratório, por exemplo, o cliente que } \\
\text { recebe em carro de passeio ou Kombi muitas } \\
\text { vezes já está tão acostumado que nem reclama } \\
\text { para a Cialab." } \\
\text { "Não cumprimento do procedimento ou não } \\
\text { adequação as necessidades (Com relação a } \\
\text { corte de transportador). Tínhamos um } \\
\text { fornecedor que possuía diversas entregas para } \\
\text { fazer junto com as nossas em um carro só, } \\
\text { porém quando precisávamos que ele esperasse } \\
\text { mais em uma entrega ele saia do local sem a } \\
\text { minha autorização.” }\end{array}$ & $\begin{array}{l}\text { Em casos de } \\
\text { menor impacto, a } \\
\text { Air Cargo dá } \\
\text { liberdade para os } \\
\text { transportadores } \\
\text { trabalharem fora } \\
\text { do padrão. Porém } \\
\text { em casos mais } \\
\text { difíceis, nenhum } \\
\text { dos lados cedeu e } \\
\text { a parceria foi } \\
\text { rompida. }\end{array}$ & Equilíbrio \\
\hline Autonomia & $\begin{array}{l}\text { "O Laboratório faz muitas exigências de } \\
\text { procedimentos (...), porém em alguns locais } \\
\text { distantes as pessoas estão tão acostumadas a } \\
\text { receberem fora do padrão que nem reclamam } \\
\text { com o laboratório, por exemplo, o cliente que } \\
\text { recebe em carro de passeio ou Kombi muitas } \\
\text { vezes já está tão acostumado que nem reclama } \\
\text { para a Cialab." } \\
\text { Análise do Questionário Autonomia para } \\
\text { Execução do Serviço: o fornecedor não tem } \\
\text { praticamente opções, entretanto conforme } \\
\text { informado estes parceiros não subcontratam, } \\
\text { logo não faz sentido eles terem essa opção) }\end{array}$ & $\begin{array}{l}\text { O questionário } \\
\text { mostra uma } \\
\text { maior influência } \\
\text { da Air Cargo. } \\
\text { Porém a Air } \\
\text { Cargo também } \\
\text { abre exceções }\end{array}$ & $\begin{array}{c}\text { Air Cargo } \\
\text { concentra } \\
\text { mais poder }\end{array}$ \\
\hline $\begin{array}{c}\text { *Importân- } \\
\text { cia de uma } \\
\text { empresa } \\
\text { para a outra }\end{array}$ & $\begin{array}{l}\text { "Trabalhamos com } 4 \text { companhias aéreas e } \\
\text { mais } 35 \text { empresas parceiras que trabalham na } \\
\text { distribuição das cargas em nossas } 35 \text { bases. } \\
\text { Todos os parceiros são importantes, alguns } \\
\text { tem maior peso devido ao volume que } \\
\text { carregam." }\end{array}$ & $\begin{array}{l}\text { Os dois } \quad \text { são } \\
\text { importantes }\end{array}$ & Equilíbrio \\
\hline $\begin{array}{c}\text { *Participa- } \\
\text { ção no } \\
\text { faturamento }\end{array}$ & (sem informações disponíveis) & $\begin{array}{l}\text { (sem } \\
\text { informações } \\
\text { disponíveis) }\end{array}$ & $\begin{array}{l}\text { Desconsi- } \\
\text { derar }\end{array}$ \\
\hline
\end{tabular}


Conclusão final: Air Cargo possui uma fraca influência sobre os transportadores. De 3 itens, 2 são equilíbrio e um a favor da Air Cargo.

\subsection{Relacionamento Air Cargo - Cia Aéreas}

\begin{tabular}{|c|c|c|c|}
\hline Critérios & $\begin{array}{c}\text { Trechos da Entrevista, Visitas e } \\
\text { Documentos }\end{array}$ & Análise & Resultado \\
\hline Negociações & $\begin{array}{l}\text { "Uma dificuldade é o extravio de } \\
\text { carga, isso pode ocorrer nas conexões, } \\
\text { como perda de bagagem. Em casos } \\
\text { quando o destinatário é muito rígido e } \\
\text { não flexibiliza para conseguir receber } \\
\text { e a carga em questão for perecível, } \\
\text { então toda carga perecerá. Em um } \\
\text { caso desses a Companhia Aérea } \\
\text { perdeu uma carga de R\$ } 280 \text { mil, mas } \\
\text { não conseguimos ressarcimento da } \\
\text { Companhia Aérea, como comprar o } \\
\text { seguro da Companhia Aérea } \\
\text { inviabilizaria a operação, o prejuízo } \\
\text { ficou para a Air Cargo." } \\
\text { "Temos poucas opções de } \\
\text { companhias aéreas, } 5 \text { no total, } \\
\text { entretanto somente } 2 \text { com uma boa } \\
\text { malha de atendimento, as quais } \\
\text { possuem grande poder nas } \\
\text { negociações, assim elas podem cobrar } \\
\text { caro sem operar com muita } \\
\text { qualidade." } \\
\text { "Nossa relação com a companhia } \\
\text { aérea depende do trecho que estamos } \\
\text { falando, se forem vôos para regiões } \\
\text { muito movimentadas onde a } \\
\text { companhia aérea possuir grande } \\
\text { concorrência aí temos uma briga boa, } \\
\text { mas em trechos para região norte } \\
\text { onde há um monopólio, aí eles tem } \\
\text { muita força." } \\
\text { "Só uma companhia aérea possui } \\
\text { cargueiros, para conseguir espaço } \\
\text { nessas aeronaves preciso dar carga de } \\
\text { outros trechos para eles, pois espaços } \\
\text { nos cargueiros são muito essenciais } \\
\text { no final do ano. Nos grandes pontos } \\
\text { de conexão como Brasília nos temos } \\
\text { funcionários dentro dos aeroportos e } \\
\text { uma sala lá, assim conseguimos } \\
\text { influenciar e verificar a operação mais } \\
\text { de perto." }\end{array}$ & $\begin{array}{l}\text { A Air } \text { Cargo perdeu } \\
\text { dinheiro com carga } \\
\text { roubada e existem só } 2 \\
\text { fornecedores no mercado. } \\
\text { Colocam um funcionário } \\
\text { próximo a companhia } \\
\text { para ter mais influência, } \\
\text { mas não aumentam seu } \\
\text { poder }\end{array}$ & $\begin{array}{c}\text { Cia Aérea } \\
\text { concentra } \\
\text { mais poder }\end{array}$ \\
\hline
\end{tabular}




\begin{tabular}{|c|c|c|c|}
\hline Autonomia & $\begin{array}{l}\text { "As companhias aéreas que } \\
\text { transportam cargas são as mesmas } \\
\text { companhias que transportam } \\
\text { pessoas". Em nossa principal } \\
\text { companhia aérea somos o maior } \\
\text { embarcador de } \\
\text { "A copa do mundo não nos impactou } \\
\text { muito, somente as cidades de grande } \\
\text { volume, onde não tiveram jogos, } \\
\text { nesses casos tivemos a malha da } \\
\text { companhia aérea reduzidas. } \\
\text { Análise do Questionário Autonomia } \\
\text { para Execução do Serviço: não foi } \\
\text { aplicado para companhias aéreas) }\end{array}$ & $\begin{array}{l}\text { A Air Cargo segue a } \\
\text { programação das } \\
\text { companhias aéreas, não } \\
\text { tem influência sobre rotas, } \\
\text { horários ou modelos de } \\
\text { aviões }\end{array}$ & $\begin{array}{l}\text { Cia Aérea } \\
\text { concentra } \\
\text { mais poder }\end{array}$ \\
\hline $\begin{array}{l}\text { *Importân- } \\
\text { cia de uma } \\
\text { empresa } \\
\text { para a outra }\end{array}$ & $\begin{array}{l}\text { "Trabalhamos com } 4 \text { companhias } \\
\text { aéreas e mais } 35 \text { empresas parceiras } \\
\text { que trabalham na distribuição das } \\
\text { cargas em nossas } 35 \text { bases." } \\
\text { "As companhias aéreas que } \\
\text { transportam cargas são as mesmas } \\
\text { companhias que transportam pessoas. } \\
\text { Em nossa principal companhia aérea } \\
\text { somos o maior embarcador de carga. } \\
\text { Essa companhia aérea possui um } \\
\text { serviço de atendimento especial para } \\
\text { as } 5 \text { maiores contas deles, no qual nos } \\
\text { estamos inclusos, assim, somos } \\
\text { atendidos com prioridade." } \\
\text { "Temos poucas opções de } \\
\text { companhias aéreas, } 5 \text { no total, } \\
\text { entretanto somente } 2 \text { com uma boa } \\
\text { malha de atendimento, as quais } \\
\text { possuem grande poder nas } \\
\text { negociações, pois não há } \\
\text { concorrência, assim elas podem } \\
\text { cobrar caro sem operar com muita } \\
\text { qualidade." }\end{array}$ & $\begin{array}{l}\text { A Air Cargo possui alto } \\
\text { volume, porém as Cia } \\
\text { Aéreas com bom serviço } \\
\text { são somente duas. }\end{array}$ & Equilíbrio \\
\hline
\end{tabular}




\begin{tabular}{|c|c|c|c|}
\hline $\begin{array}{c}\text { *Participa- } \\
\text { ção no } \\
\text { faturamento }\end{array}$ & $\begin{array}{l}\text { "R\$ } 36 \text { milhões por ano no aéreo } \\
\text { (gastos com compra de transporte } \\
\text { aéreo), R } \$ 30 \text { milhões estão } \\
\text { concentrados em uma única } \\
\text { companhia aérea. Fora isso temos } \\
\text { altos gastos de terceiros, motoristas } \\
\text { agregados, infraestrutura e folha de } \\
\text { pagamento." }\end{array}$ & $\begin{array}{l}\text { Não temos dados do } \\
\text { percentual do faturamento } \\
\text { da companhia aérea. Mas } \\
\text { pela prioridade de cargas } \\
\text { sabemos que em primeiro } \\
\text { lugar vem as bagagens } \\
\text { dos passageiros e depois a } \\
\text { carga aérea, isso parece } \\
\text { ser um indício de que a } \\
\text { primeira receita é em } \\
\text { passageiros. Para a Air } \\
\text { Cargo é muito importante, } \\
83 \% \text { dos seus custos de } \\
\text { frete estão em um } \\
\text { fornecedor. }\end{array}$ & $\begin{array}{l}\text { Cia Aérea } \\
\text { concentra } \\
\text { mais poder }\end{array}$ \\
\hline
\end{tabular}

Conclusão final: a Cia Aérea possui forte Centralização de poder sobre a Air Cargo, 3 pontos a favor da Cia Aérea e 1 em equilíbrio. 


\subsubsection{Formalização}

\subsection{Air Cargo - Eurochain}

\begin{tabular}{|c|c|c|c|}
\hline Critérios & $\begin{array}{c}\text { Trechos da Entrevista, Visitas e } \\
\text { Documentos }\end{array}$ & Análise & Resultado \\
\hline $\begin{array}{l}\text { Preços definidos } \\
\text { e formalizados? }\end{array}$ & $\begin{array}{l}\text { "Não disponível, o entrevistado } \\
\text { mostrou certo desconforto e disse } \\
\text { que não poderia mostrar a tabela." }\end{array}$ & \begin{tabular}{|lrr} 
Não sei & se \\
tabela não foi \\
mostrada & porque \\
não havia & ou por \\
sigilo & de \\
informação &
\end{tabular} & Desconsiderada \\
\hline $\begin{array}{l}\text { Níveis de } \\
\text { serviços estão } \\
\text { acordados e } \\
\text { formalizados? }\end{array}$ & $\begin{array}{l}\text { * Relatório de Performance Air Cargo } \\
\text { e todas as contas da Eurochanel. } \\
\text { Indicadores de entrega e informação } \\
\text { no prazo por cliente, por estado, } \\
\text { target de nível de serviço, por } \\
\text { semana. }\end{array}$ & $\begin{array}{l}\text { Meta } \\
\text { formalizada, } \\
\text { manter } 98 \% \text { de } \\
\text { entregas bem } \\
\text { sucedidas (prazo } \\
\text { e integridade) }\end{array}$ & Formal \\
\hline $\begin{array}{l}\text { Acompanhamen } \\
\text { to do nível de } \\
\text { serviço? }\end{array}$ & $\begin{array}{l}\text { * Relatório de Performance Air Cargo } \\
\text { e todas as contas da Eurochanel. } \\
\text { Indicadores de entrega e informação } \\
\text { no prazo por cliente, por estado, } \\
\text { target de nível de serviço, por } \\
\text { semana. }\end{array}$ & $\begin{array}{lr}\text { O r r ratório } \\
\text { mostra } & \text { o } \\
\text { acompanhamento } \\
\text { semanal }\end{array}$ & Formal \\
\hline $\begin{array}{l}\text { Existe uma } \\
\text { prática de } \\
\text { reuniões } \\
\text { operacionais } \\
\text { padrão entre } \\
\text { fornecedor e } \\
\text { cliente? }\end{array}$ & $\begin{array}{l}\text { * Ata de reunião entre Air Cargo e } \\
\text { Eurochain com lista de problemas e } \\
\text { ações corretivas e prazos para } \\
\text { solução. (segundo entrevistado havia } \\
\text { uma prática de reunião mensal) }\end{array}$ & $\begin{array}{l}\text { Controle } \\
\text { efetuado por } \\
\text { reuniões mensais }\end{array}$ & Formal \\
\hline $\begin{array}{l}\text { Existem regras } \\
\text { padronizadas } \\
\text { com relação aos } \\
\text { riscos de carga } \\
\text { de alto valor? } \\
\end{array}$ & $\begin{array}{l}\text { * Regras de Gerenciamento de Risco } \\
\text { - regras de } 18 \text { laboratórios em um } \\
\text { único documento } 1 \text {. }\end{array}$ & $\begin{array}{l}\text { Documento com } \\
\text { todas as regras } \\
\text { inclusive as da } \\
\text { Cialab }\end{array}$ & Formal \\
\hline $\begin{array}{l}\text { Contexto } \\
\text { (aplicado a } \\
\text { todas as } \\
\text { dimensões) }\end{array}$ & $\begin{array}{l}\text { (No dia da entrevista eles tiveram } \\
\text { uma auditoria surpresa de um dos } \\
\text { clientes farmacêuticos) } \\
\text { *Ata de reunião entre Air Cargo e } \\
\text { Eurochain com lista de problemas e } \\
\text { ações corretivas e prazos para } \\
\text { solução. } \\
\text { "Alguns locais se você for visitar, } \\
\text { você não vai achar tão bonito, por } \\
\text { exemplo, Petrolina -Pernambuco e } \\
\text { Ilhéus Bahia. (sobre qualidade das }\end{array}$ & $\begin{array}{lr}\text { Existe } & \text { muita } \\
\text { cobrança } & \text { por } \\
\text { formalização } & \text { e } \\
\text { padronização } & \\
\text { quanto } & \text { mais } \\
\text { próximo } & \text { da } \\
\text { indústria, } & \text { mas } \\
\text { nos } & \\
\text { transportadores } \\
\text { finais } & \text { parece } \\
\text { haver } & \text { maior }\end{array}$ & Equilíbrio \\
\hline
\end{tabular}




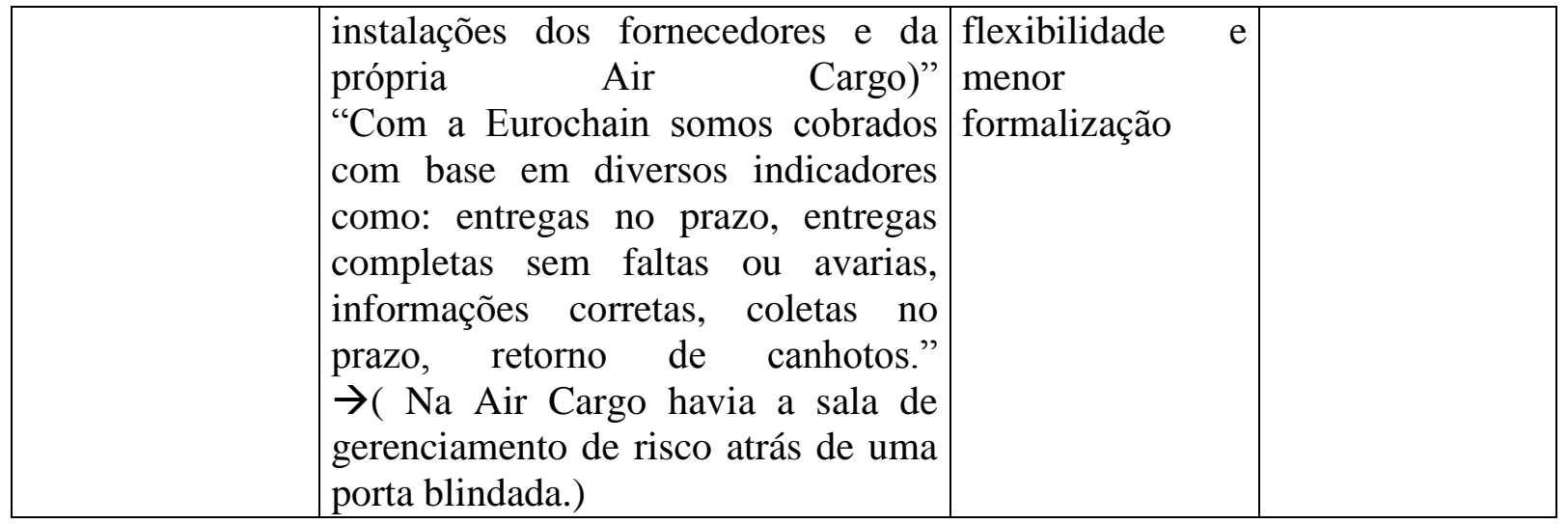

Conclusão final: de 5 critérios considerados 4 mostram formalidade, assim o resultado é Alta formalidade

\subsection{Air Cargo - Transportador Rodoviário}

\begin{tabular}{|c|c|c|c|}
\hline Critérios & Trechos da Entrevista, Visitas e Documentos & Análise & $\begin{array}{c}\text { Resultad } \\
\text { o }\end{array}$ \\
\hline $\begin{array}{c}\text { Preços } \\
\text { definidos e } \\
\text { formalizados } \\
?\end{array}$ & $\begin{array}{l}\text { *- Tabela de preço de fornecedor - tipos de veículos } \\
\text { utilizados e seus respectivos custos. }\end{array}$ & $\begin{array}{l}\text { tabela } \\
\text { exibida }\end{array}$ & Formal \\
\hline $\begin{array}{l}\text { Níveis de } \\
\text { serviços } \\
\text { estão } \\
\text { acordados e } \\
\text { formalizados } \\
\quad ?\end{array}$ & $\begin{array}{l}\text { "Não acompanhamos a performance por fornecedor, } \\
\text { somente a performance total. Quando temos problemas } \\
\text { fazemos reuniões. Temos um projeto que já está iniciado } \\
\text { para fazermos o acompanhamento por fornecedores. } \\
\text { Comercial, meu time acompanha as entregas com o time } \\
\text { dos fornecedores e quando preciso faço reuniões com } \\
\text { eles." }\end{array}$ & $\begin{array}{l}\text { não } \\
\text { existe } \\
\text { esse } \\
\text { controle }\end{array}$ & Informal \\
\hline $\begin{array}{c}\text { Acompanha } \\
\text { mento do } \\
\text { nível de } \\
\text { serviço? }\end{array}$ & $\begin{array}{l}\text { Não acompanhamos a performance por fornecedor, } \\
\text { somente a performance total. Quando temos problemas } \\
\text { fazemos reuniões. Temos um projeto que já está iniciado } \\
\text { para fazermos o acompanhamento por fornecedores. } \\
\text { Comercial, meu time acompanha as entregas com o time } \\
\text { dos fornecedores e quando preciso faço reuniões com } \\
\text { eles." } \\
\text { *- Relatório de Performance Air Cargo e todas as contas } \\
\text { da Eurochanel. Indicadores de entrega e informação no } \\
\text { prazo por cliente, por estado, target de nível de serviço, } \\
\text { por semana. }\end{array}$ & $\begin{array}{l}\text { não } \\
\text { existe } \\
\text { esse } \\
\text { controle }\end{array}$ & Informal \\
\hline \begin{tabular}{|l|} 
Existe uma \\
prática de \\
reuniões \\
operacionais \\
padrão entre \\
fornecedor e \\
cliente? \\
\end{tabular} & $\begin{array}{l}\text { "Não acompanhamos a performance por fornecedor, } \\
\text { somente a performance total. Quando temos problemas } \\
\text { fazemos reuniões. Temos um projeto que já está iniciado } \\
\text { para fazermos o acompanhamento por fornecedores. } \\
\text { Comercial, meu time acompanha as entregas com o time } \\
\text { dos fornecedores e quando preciso faço reuniões com } \\
\text { eles." }\end{array}$ & $\begin{array}{l}\text { não } \\
\text { existe } \\
\text { essa } \\
\text { prática }\end{array}$ & Informal \\
\hline
\end{tabular}




\begin{tabular}{|c|c|c|c|}
\hline $\begin{array}{c}\text { Existem } \\
\text { regras } \\
\text { padronizada } \\
\text { s com } \\
\text { relação aos } \\
\text { riscos de } \\
\text { carga de alto } \\
\text { valor? }\end{array}$ & $\begin{array}{l}\text { "Esses transportadores não precisam ter todas as nossas } \\
\text { licenças, pois algumas de nossas licenças têm função } \\
\text { "guarda-chuva", ou seja, serve também para as empresas } \\
\text { que nós contratamos." }\end{array}$ & $\begin{array}{l}\text { não } \\
\text { existe } \\
\text { esse } \\
\text { controle }\end{array}$ & Informal \\
\hline $\begin{array}{l}\text { Contexto } \\
\text { (aplicado a } \\
\text { todas as } \\
\text { dimensões) }\end{array}$ & 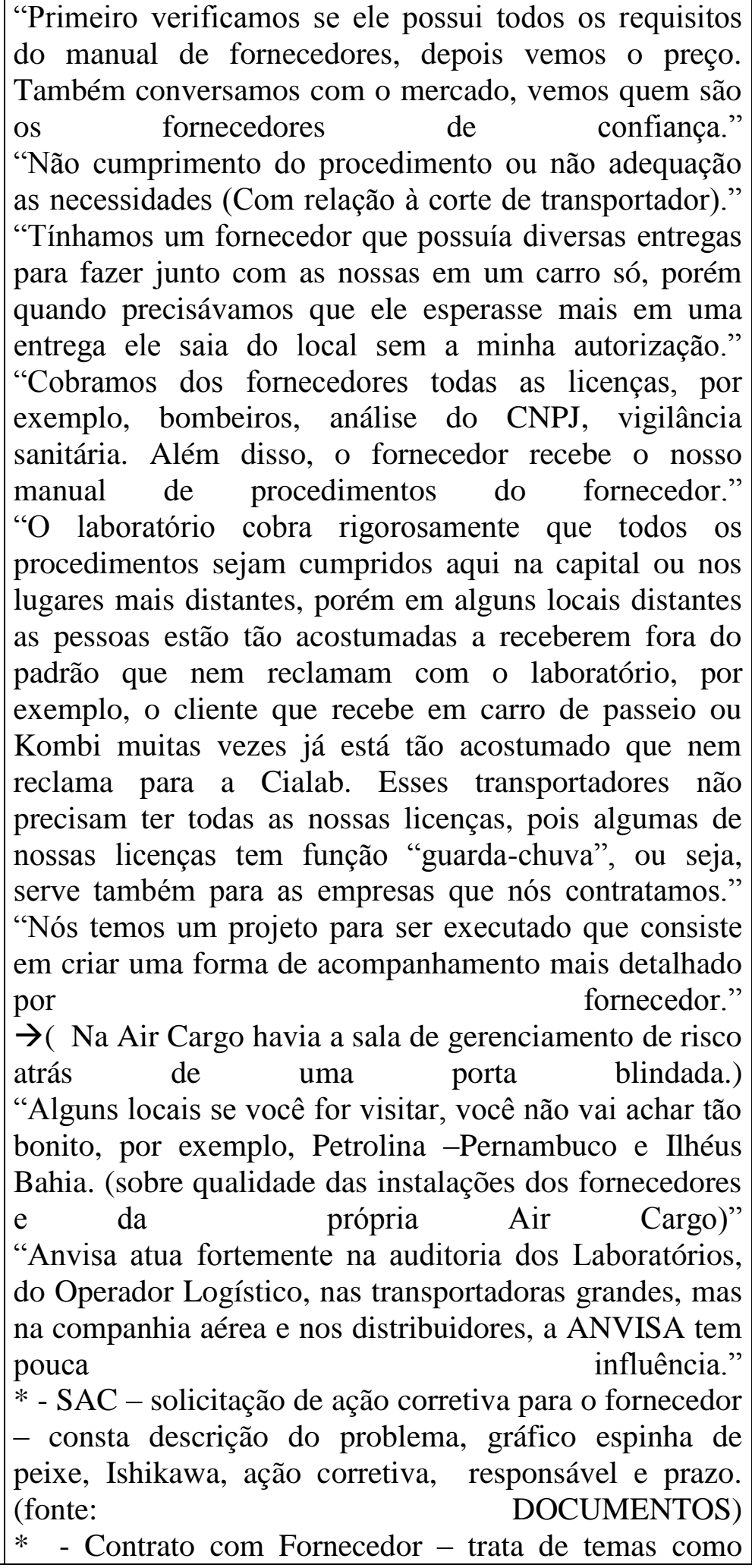 & $\begin{array}{l}\text { Para a } \\
\text { contrata } \\
\text { ção foi } \\
\text { evidenci } \\
\text { ado um } \\
\text { controle } \\
\text { rigoroso } \\
\text {, mas } \\
\text { uma vez } \\
\text { contrata } \\
\text { do os } \\
\text { processo } \\
\text { s de } \\
\text { acompa } \\
\text { nhament } \\
\text { o } \quad \text { e } \\
\text { procedi } \\
\text { mentos } \\
\text { não são } \\
\text { formaliz } \\
\text { ados }\end{array}$ & Informal \\
\hline
\end{tabular}




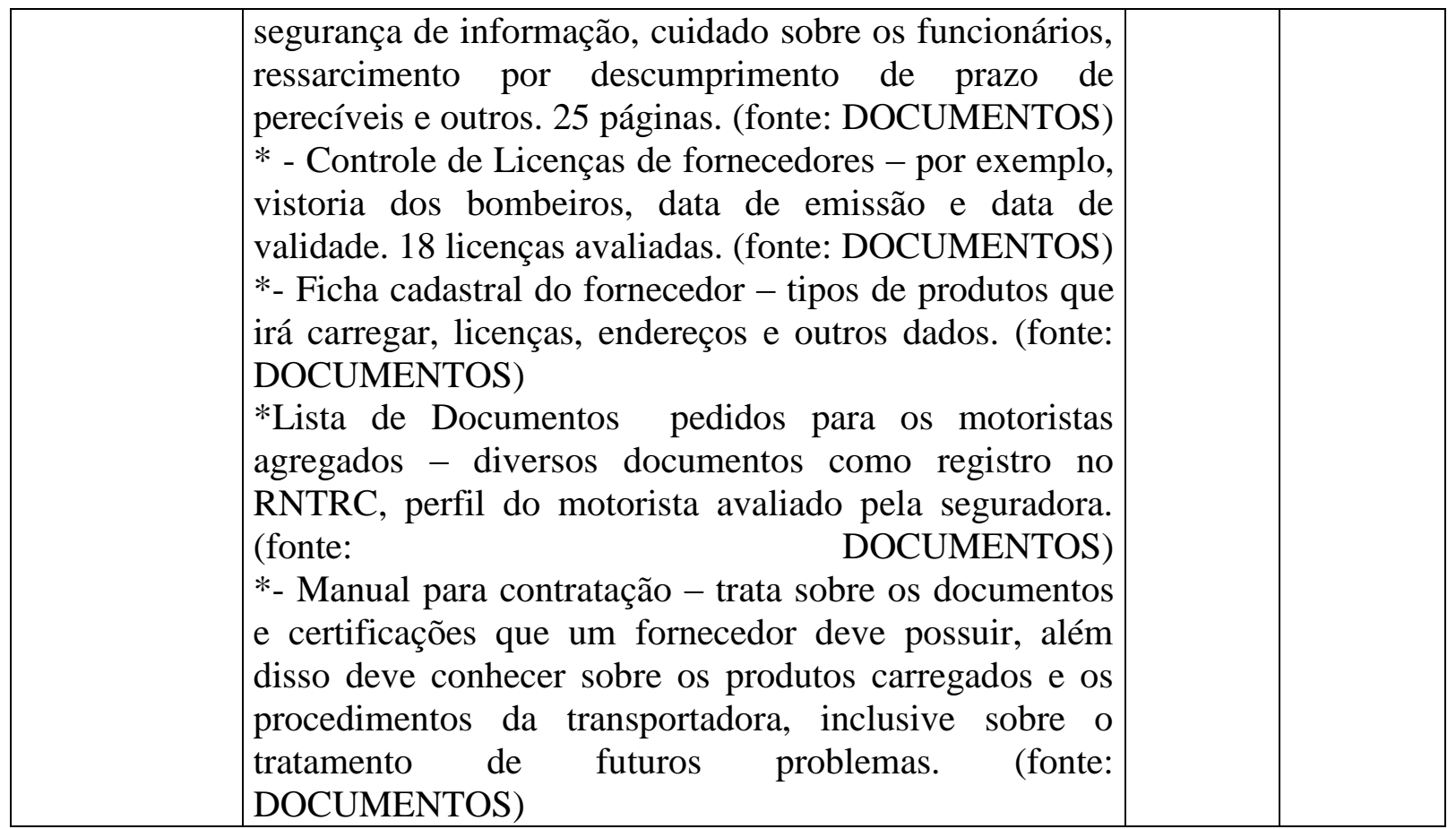

Conclusão final: 5 critérios considerados informais, 1 critério considerado formal. Análise final, forte informalidade

\subsection{Air Cargo - Companhia Aérea}

\begin{tabular}{|c|c|c|c|}
\hline Critérios & $\begin{array}{l}\text { Trechos da Entrevista, } \\
\text { Visitas e Documentos }\end{array}$ & Análise & Resultado \\
\hline $\begin{array}{c}\text { Preços definidos e } \\
\text { formalizados? }\end{array}$ & $\begin{array}{lr}\text { Nenhum documento } & \text { foi } \\
\text { apresentado } & \text { pelo } \\
\text { entrevistado. } & \end{array}$ & $\begin{array}{l}\text { Não sei se a tabela não } \\
\text { foi mostrada porque } \\
\text { não havia ou por sigilo } \\
\text { de informação }\end{array}$ & Desconsiderado \\
\hline $\begin{array}{c}\text { Níveis de serviços } \\
\text { estão acordados e } \\
\text { formalizados? }\end{array}$ & $\begin{array}{l}\text { *_ Programação dos vôos } \\
\text { disponíveis fornecido pela } \\
\text { companhia aérea para o } \\
\text { planejamento da Air Cargo. }\end{array}$ & $\begin{array}{l}\text { Desconsiderar esse } \\
\text { critério, pois as rotas e } \\
\text { horários nunca são } \\
\text { fixos para companhias } \\
\text { aéreas. }\end{array}$ & Desconsiderados \\
\hline $\begin{array}{l}\text { Acompanhamento } \\
\text { do nível de } \\
\text { serviço? }\end{array}$ & $\begin{array}{l}\text { *- Relatório de Performance } \\
\text { Air Cargo e todas as contas } \\
\text { da Eurochanel. Indicadores de } \\
\text { entrega e informação no } \\
\text { prazo por cliente, por estado, } \\
\text { target de nível de serviço, por } \\
\text { semana. }\end{array}$ & $\begin{array}{lr}\text { Não foi } & \text { mostrado } \\
\text { nenhuma } & \text { evidência } \\
\text { desse } & \text { controle, } \\
\text { somente na visita foi } \\
\text { evidenciado } & \text { que } \\
\text { algumas } & \text { pessoas } \\
\text { controlam o status dos } \\
\text { voôs, mas } & \text { nenhum } \\
\text { relatório } & \text { gerencial } \\
\text { sobre a Cia Aérea. }\end{array}$ & Informal \\
\hline
\end{tabular}




\begin{tabular}{|c|c|c|c|}
\hline $\begin{array}{l}\text { Existe uma } \\
\text { prática de } \\
\text { reuniões } \\
\text { operacionais } \\
\text { padrão entre } \\
\text { fornecedor e } \\
\text { cliente? }\end{array}$ & (sem evidência) & $\begin{array}{l}\text { não, não são feitas } \\
\text { reuniões com datas pré } \\
\text { determinadas, somente } \\
\text { reuniões comerciais }\end{array}$ & Informal \\
\hline $\begin{array}{c}\text { Existem regras } \\
\text { padronizadas com } \\
\text { relação aos riscos } \\
\text { de carga de alto } \\
\text { valor? }\end{array}$ & (sem evidência) & (sem evidência) & Informal \\
\hline $\begin{array}{c}\text { Contexto } \\
\text { (aplicado a todas } \\
\text { as dimensões) }\end{array}$ & $\begin{array}{l}\text { "Anvisa atua fortemente na } \\
\text { auditoria dos Laboratórios, do } \\
\text { Operador Logístico, nas } \\
\text { transportadoras grandes, mas } \\
\text { na companhia aérea e nos } \\
\text { distribuidores, a ANVISA } \\
\text { tem pouca influência." }\end{array}$ & $\begin{array}{l}\text { As vistorias da Anvisa } \\
\text { nos aeroportos são } \\
\text { fracas }\end{array}$ & Informal \\
\hline
\end{tabular}

Conclusão final: Como a companhia aérea não foi entrevistada, não será possível cruzar dados, mas há fortes indícios de informalidade nas atividades da companhia aérea e no controle da Air Cargo sobre a Cia Aérea.

\subsubsection{Integração}

\subsection{Air cargo - Eurochain}

\begin{tabular}{|c|c|c|c|}
\hline Critérios & $\begin{array}{c}\text { Trechos da Entrevista, Visitas e } \\
\text { Documentos }\end{array}$ & Análise & Resultado \\
\hline $\begin{array}{l}\text { Iniciativas em } \\
\text { conjunto que } \\
\text { proporcionem } \\
\text { benefícios } \\
\text { para ambas as } \\
\text { empresas }\end{array}$ & $\begin{array}{l}\text { "A Eurochain impôs que muitos } \\
\text { transportadores teriam que colocar uma equipe } \\
\text { dentro do Centro de Distribuição da Eurochain } \\
\text { para fazer a conferência. Nós colocamos uma } \\
\text { equipe lá de } 8 \text { pessoas com custo Air Cargo e } \\
\text { sem reajuste na tarifa." } \\
\text { "Não existe (trabalha em conjunto), não temos } \\
\text { nenhum tipo de "cadeia colaborativa", cada } \\
\text { um olha o seu mundo." }\end{array}$ & $\begin{array}{l}\text { Não existe } \\
\text { colaboração, } \\
\text { pelo contrário, } \\
\text { são impostas } \\
\text { medidas que } \\
\text { impõe prejuízos } \\
\text { para o lado } \\
\text { mais fraco. }\end{array}$ & $\begin{array}{c}\text { Sem } \\
\text { Integração }\end{array}$ \\
\hline $\begin{array}{c}\text { Contexto } \\
\text { (aplicado a } \\
\text { todas as } \\
\text { dimensões) }\end{array}$ & $\begin{array}{l}\text { "Sim, tudo é feito a } 4 \text { mãos. Porém, creio que } \\
\text { isso também tem relação com a nossa } \\
\text { importância para eles, pois já trabalhei com a } \\
\text { Eurochain por outras empresas, mas não era } \\
\text { ouvido nas propostas de melhorias que fiz, } \\
\text { hoje sou ouvido nas mesmas propostas." }\end{array}$ & $\begin{array}{l}\text { A Eurochain } \\
\text { considera a Air } \\
\text { Cargo uma } \\
\text { empresa } \\
\text { importante }\end{array}$ & Indiferente \\
\hline
\end{tabular}




\begin{tabular}{|c|c|c|c|}
\hline $\begin{array}{l}\text { *Comunica- } \\
\text { ção }\end{array}$ & $\begin{array}{l}\text { "Às vezes a Eurochain nos pede para fazer um } \\
\text { aéreo, mas sabemos que ir pelo rodoviário será } \\
\text { mais vantajoso, nesses casos mesmo que não } \\
\text { ganhemos o transporte avisamos a Eurochain } \\
\text { para que ela possa ter o melhor nível de } \\
\text { serviço." }\end{array}$ & $\begin{array}{l}\text { Transparência } \\
\text { da parte da } \\
\text { AirCargo, } \\
\text { abdicando de } \\
\text { ganhos maiores } \\
\text { para auxiliar o } \\
\text { cliente. }\end{array}$ & $\begin{array}{c}\text { Sem } \\
\text { Integração }\end{array}$ \\
\hline *Confiança & 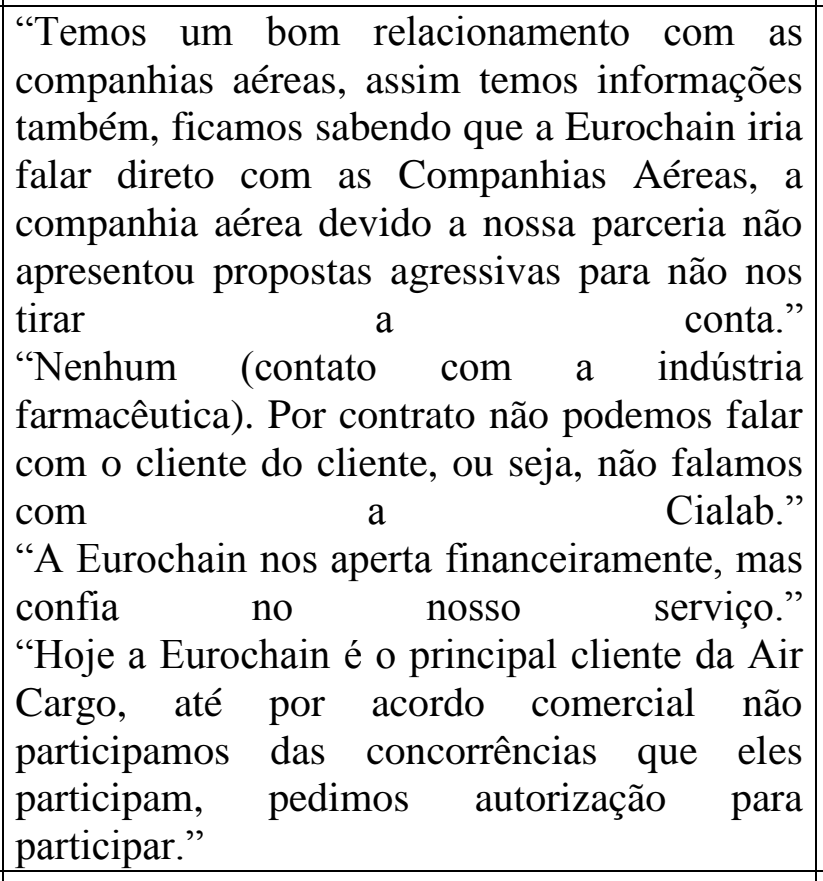 & \begin{tabular}{lr}
\multicolumn{3}{|l}{ Apesar da } & Air \\
Cargo dizer que \\
possui r bom \\
relacionamento \\
eles r não \\
possuem $r$ a \\
confiança da \\
Eurochain que \\
não os permite \\
nem falar com \\
os seus clientes. \\
A Eurochain \\
também rem \\
avisar a Air \\
Cargo tentou \\
cotar preços \\
diretos com a \\
Cia Aérea
\end{tabular} & $\begin{array}{c}\text { Sem } \\
\text { Integração }\end{array}$ \\
\hline $\begin{array}{l}* \text { Tempo de } \\
\text { relacionamen- } \\
\text { to }\end{array}$ & $\begin{array}{l}\text { "Já faz 2,5 anos que temos esta conta } \\
\text { Eurochain e Cialab." }\end{array}$ & $\begin{array}{l}\text { pouco tempo de } \\
\text { relacionamento }\end{array}$ & $\begin{array}{c}\text { Sem } \\
\text { Integração }\end{array}$ \\
\hline
\end{tabular}

Conclusão final: 3 critérios apontam para não integração, 1 para integração. Resultado final: Forte falta de integração

\subsection{Air cargo - Transportador Rodoviário}

\begin{tabular}{|c|c|c|c|}
\hline Critérios & $\begin{array}{c}\text { Trechos da Entrevista, Visitas e } \\
\text { Documentos }\end{array}$ & Análise & Resultado \\
\hline $\begin{array}{c}\text { Iniciativas em } \\
\text { conjunto que } \\
\text { proporcionem } \\
\text { benefícios } \\
\text { para ambas as } \\
\text { empresas }\end{array}$ & $\begin{array}{l}\text { "Não existe (trabalha em conjunto), } \\
\text { não temos nenhum tipo de "cadeia } \\
\text { colaborativa", cada um olha o seu } \\
\text { mundo." }\end{array}$ & $\begin{array}{l}\text { O trecho da conversa ao } \\
\text { lado foi em geral, mas } \\
\text { nenhumar outra } \\
\text { evidência foi mostrada. }\end{array}$ & $\begin{array}{c}\text { Sem } \\
\text { Integração }\end{array}$ \\
\hline $\begin{array}{l}\text { Contexto } \\
\text { (aplicado a } \\
\text { todas as } \\
\text { dimensões) }\end{array}$ & $\begin{array}{l}\text { "Temos parcerias há muitos anos, } \\
\text { trocar o fornecedor é em último caso. } \\
\text { Sempre tentamos desenvolvê-los." }\end{array}$ & $\begin{array}{l}\text { A princípio existe uma } \\
\text { preocupação com o } \\
\text { desenvolvimento dos } \\
\text { parceiros }\end{array}$ & Integração \\
\hline
\end{tabular}




\begin{tabular}{|c|c|c|c|}
\hline $\begin{array}{l}\text { *Comunica- } \\
\text { ção }\end{array}$ & $\begin{array}{l}\text { "Não acompanhamos a performance } \\
\text { por fornecedor, somente a } \\
\text { performance total. Quando temos } \\
\text { problemas fazemos reuniões. Temos } \\
\text { um projeto que já está iniciado para } \\
\text { fazermos o acompanhamento por } \\
\text { fornecedores. } \\
\text { Comercial, meu time acompanha as } \\
\text { entregas com o time dos fornecedores } \\
\text { e quando preciso faço reuniões com } \\
\text { eles." }\end{array}$ & $\begin{array}{l}\text { Comunicação } \\
\text { meramente operacional }\end{array}$ & $\begin{array}{c}\text { Sem } \\
\text { Integração }\end{array}$ \\
\hline *Confiança & $\begin{array}{l}\text { "Também conversamos com o } \\
\text { mercado, vemos quem são os } \\
\text { fornecedores de confiança. (sobre } \\
\text { auxílio para contratação de } \\
\text { fornecedores)." } \\
\text { "Quando nós chegamos, algumas } \\
\text { pessoas ficaram na equipe para passar } \\
\text { informações para concorrentes." }\end{array}$ & $\begin{array}{l}\text { Com relação ao mercado } \\
\text { depende, } \\
\text { concorrentes } \\
\text { colaboram e outros } \\
\text { desleais. Como nenhum } \\
\text { dos casos diz respeito a } \\
\text { uma empresa da cadeia, } \\
\text { então desconsiderar este } \\
\text { critério. }\end{array}$ & $\begin{array}{l}\text { Desconsi- } \\
\text { derado }\end{array}$ \\
\hline $\begin{array}{c}* \text { Tempo de } \\
\text { relacionament } \\
\quad 0\end{array}$ & \begin{tabular}{|l} 
"Temos transportadores \\
trabalham conosco há mais de 10 \\
anos, mas em média considero 5 anos. \\
Sim, eles apresentam uma boa \\
performance."
\end{tabular} & médio prazo & Indiferente \\
\hline
\end{tabular}

Conclusão Final: 2 critérios apontam a falta de integração, 1 critério aponta a integração, resultado, falta integração.

\subsection{Air cargo - Companhias Aéreas}

\begin{tabular}{|c|c|c|c|}
\hline Critérios & $\begin{array}{c}\text { Trechos da Entrevista, Visitas e } \\
\text { Documentos }\end{array}$ & Análise & Resultado \\
\hline $\begin{array}{l}\text { Iniciativas em } \\
\text { conjunto que } \\
\text { proporcionem } \\
\text { benefícios } \\
\text { para ambas as } \\
\text { empresas }\end{array}$ & $\begin{array}{l}\text { "Não existe (trabalha em conjunto), não temos } \\
\text { nenhum tipo de "cadeia colaborativa", cada } \\
\text { um olha o seu mundo." }\end{array}$ & $\begin{array}{lr}\text { O trecho } & \text { da } \\
\text { conversa } & \text { ao } \\
\text { lado foi } & \text { em } \\
\text { geral, } & \text { mas } \\
\text { nenhuma } & \text { outra } \\
\text { evidência } & \text { foi } \\
\text { mostrada. } & \end{array}$ & Indiferente \\
\hline $\begin{array}{l}\text { Contexto } \\
\text { (aplicado a } \\
\text { todas as } \\
\text { dimensões) }\end{array}$ & $\begin{array}{l}\text { "As companhias aéreas que transportam cargas } \\
\text { são as mesmas companhias que transportam } \\
\text { pessoas. Em nossa principal companhia aérea } \\
\text { somos o maior embarcador de carga. Essa } \\
\text { companhia aérea possui um serviço de } \\
\text { atendimento especial para as } 5 \text { maiores contas } \\
\text { deles, no qual nos estamos inclusos, assim, } \\
\text { somos atendidos com prioridade." }\end{array}$ & $\begin{array}{l}\text { São clientes } \\
\text { considerados } \\
\text { importantes e } \\
\text { são atendidos } \\
\text { de forma } \\
\text { especial }\end{array}$ & Integração \\
\hline
\end{tabular}




\begin{tabular}{|c|c|c|c|}
\hline $\begin{array}{l}\text { *Comunica- } \\
\text { ção }\end{array}$ & $\begin{array}{l}\text { "As companhias aéreas que transportam cargas } \\
\text { são as mesmas companhias que transportam } \\
\text { pessoas. Em nossa principal companhia aérea } \\
\text { somos o maior embarcador de carga. Essa } \\
\text { companhia aérea possui um serviço de } \\
\text { atendimento especial para as } 5 \text { maiores contas } \\
\text { deles, no qual nos estamos inclusos, assim, } \\
\text { somos atendidos com prioridade." } \\
\text { "Temos um bom relacionamento com as } \\
\text { companhias aéreas, assim temos informações } \\
\text { também, ficamos sabendo que a Eurochain iria } \\
\text { falar direto com a Companhias Aéreas, a } \\
\text { companhia aérea devido a nossa parceria não } \\
\text { apresentou propostas agressivas para não nos } \\
\text { tirar a conta." }\end{array}$ & $\begin{array}{l}\text { Além do } \\
\text { atendimento } \\
\text { especial, existe } \\
\text { uma confiança } \\
\text { que } \\
\text { proporcionou a } \\
\text { informação de } \\
\text { que seu cliente } \\
\text { Eurochain } \\
\text { estava tentando } \\
\text { ir diretamente a } \\
\text { seus } \\
\text { fornecedores. }\end{array}$ & Integração \\
\hline *Confiança & $\begin{array}{l}\text { "Temos um bom relacionamento com as } \\
\text { companhias aéreas, assim temos informações } \\
\text { também, ficamos sabendo que a Eurochain iria } \\
\text { falar direto com as Companhias Aéreas, a } \\
\text { companhia aérea devido a nossa parceria não } \\
\text { apresentou propostas agressivas para não nos } \\
\text { tirar a conta." }\end{array}$ & $\begin{array}{l}\text { Houve } \\
\text { confiança por } \\
\text { parte da Cia } \\
\text { Aérea para } \\
\text { contar } \\
\text { informações } \\
\text { sigilosas para a } \\
\text { Air cargo }\end{array}$ & Integração \\
\hline $\begin{array}{c}\text { * Tempo de } \\
\text { relacionament } \\
\text { o }\end{array}$ & $\begin{array}{l}\text { (sem evidências: disseram que há poucos anos } \\
\text { surgiram novas empresas para se trabalhar) }\end{array}$ & - & $\begin{array}{l}\text { Desconsi- } \\
\text { derado }\end{array}$ \\
\hline
\end{tabular}

Conclusão final: embora não exista uma iniciativa de integração como demonstra a literatura, neste relacionamento parece existir confiança e comunicação que possa ser um campo fértil para uma futura iniciativa. De 4 itens 3 são a favor da integração. 


\subsubsection{Análise intra-empresa Sul Deste Cargo}

\subsubsection{Centralização}

\subsubsection{Relacionamento Sul Deste Cargo - Eurochain}

\begin{tabular}{|c|c|c|c|}
\hline Critérios & $\begin{array}{l}\text { Trechos da Entrevista, Visitas e } \\
\text { Documentos }\end{array}$ & Análise & Resultado \\
\hline Negociações & $\begin{array}{l}\text { "A Eurochain aperta muito nos } \\
\text { preços, ela é bem agressiva também } \\
\text { nos níveis de serviço e na cobrança, } \\
\text { mas também a área é exigente } \\
\text { devido à vigilância sanitária." } \\
\text { "Sim, a conta é lucrativa, mas } \\
\text { precisa ter controle da operação, } \\
\text { caso tenha erros operacionais é fácil } \\
\text { transformar a conta em prejuízo, se } \\
\text { eu perco um horário de coleta, ou } \\
\text { transferência. Se errarmos no } \\
\text { faturamento a Eurchain pede } \\
\text { prorrogação de mais } 30 \text { dias para } \\
\text { pagarmos." } \\
\text { "Existe sim multa da Eurochain para } \\
\text { nós, é recente, mas a cada problema } \\
\text { na entrega podemos perder até } 20 \% \\
\text { do valor de } \\
\text { "Para os nossos contratados não } \\
\text { existem multas e bônus, só da } \\
\text { Eurochain para nós, mas nós nunca } \\
\text { ganhamos bônus." } \\
\text { "Existe uma negociação em comum, } \\
\text { não é "top down", mas eles tem um } \\
\text { controle forte. (a Eurochain irá } \\
\text { cobrar muita performance)." }\end{array}$ & $\begin{array}{l}\text { A Sul Deste Cargo reclama } \\
\text { dos preços baixos pagos, } \\
\text { onde provavelmente foi } \\
\text { uma negociação que não os } \\
\text { agradou muito. Quando } \\
\text { existe erro de faturamento } \\
\text { eles têm o pagamento } \\
\text { atrasado. Recentemente a } \\
\text { Sul Deste Cargo começou a } \\
\text { ter multas, porém não } \\
\text { recebe bonus, ou seja, só } \\
\text { perde. É o lado fraco da } \\
\text { negociação. }\end{array}$ & $\begin{array}{l}\text { Eurochain } \\
\text { concentra } \\
\text { mais poder }\end{array}$ \\
\hline Autonomia & $\begin{array}{l}\text { "A Sul Deste Cargo não pode falar } \\
\text { com a Cialab por clausula } \\
\text { contratual." } \\
\text { Questionário Estruturado: A } \\
\text { Eurochain possui influência em } \\
\text { torno de } 5 \text { itens, mas todos itens } \\
\text { operacionais que envolvem ela } \\
\text { como as reuniões, ou então o } \\
\text { destinatário, ou seja, itens onde é } \\
\text { natural a interferência externa. } \\
\text { Todas as outras variáveis são de } \\
\text { escolha da Sul Deste Cargo, assim a } \\
\text { autonomia da Sul Deste Cargo é } \\
\text { alta). }\end{array}$ & $\begin{array}{l}\text { A Eurochain possui } \\
\text { influência em torno de } 5 \\
\text { itens, mas todos itens } \\
\text { operacionais que envolvem } \\
\text { ela como as reuniões, ou } \\
\text { então o destinatário, ou } \\
\text { seja, itens onde é natural a } \\
\text { interferência externa. Todas } \\
\text { as outras variáveis são de } \\
\text { escolha da Sul Deste } \\
\text { Cargo, assim a autonomia } \\
\text { da Sul Deste Cargo é alta }\end{array}$ & $\begin{array}{l}\text { Sul Deste } \\
\text { Cargo } \\
\text { concentra } \\
\text { mais poder }\end{array}$ \\
\hline
\end{tabular}




\begin{tabular}{|c|c|c|c|}
\hline $\begin{array}{c}\text { Contexto } \\
\text { (aplicado a } \\
\text { todas as } \\
\text { dimensões) }\end{array}$ & \begin{tabular}{|l} 
"Da gente para nossos fornecedores \\
é mais no estilo "top down". Da \\
Eurochain para nós é mais uma \\
negociação \\
"O poder dos distribuidores é muito \\
grande, eles são os grandes clientes \\
dos laboratórios, assim o laboratório \\
nunca quer entrar em conflito com \\
os seus clientes, dessa forma quando \\
temos problemas estoura para o lado \\
da Eurochain e para o lado da Sul \\
Deste Cargo."
\end{tabular} & $\begin{array}{l}\text { A Sul Deste Cargo enxerga } \\
\text { que o relacionamento com } \\
\text { a Eurochain é bom, porém } \\
\text { quando a indústria e e seus } \\
\text { clientes possuem } \\
\text { demanda elguma } \\
\text { cedendo. }\end{array}$ & Indiferente \\
\hline $\begin{array}{l}\text { *Importân- } \\
\text { cia de uma } \\
\text { empresa } \\
\text { para a outra }\end{array}$ & $\begin{array}{l}\text { "É uma conta muito importante." } \\
\text { "Da Eurochain trabalhamos com 19 } \\
\text { laboratórios no } \\
\rightarrow \text { ( Foi possível observar as docas } \\
\text { com as placas dos clientes, ou seja, } \\
\text { docas dedicadas para receber os } \\
\text { veículos da Eurochain, são docas } \\
\text { exclusivas. ) }\end{array}$ & $\begin{array}{l}\text { Do ponto de vista da Sul } \\
\text { Deste Cargo, a Eurochain é } \\
\text { uma conta muito } \\
\text { importante. }\end{array}$ & $\begin{array}{l}\text { Eurochain } \\
\text { concentra } \\
\text { mais poder }\end{array}$ \\
\hline $\begin{array}{l}\text { *Participaçã } \\
\text { o no } \\
\text { faturamento }\end{array}$ & $\begin{array}{l}\text { "R } \$ 250 \text { milhões em toda empresa } \\
\text { (receita anual). Desses } \mathrm{R} \$ 250 \\
\text { milhões, R\$ } 180 \text { milhões são do } \\
\text { transportes rodoviário, desse total } \\
30 \% \text { do rodoviário é do setor } \\
\text { farmacêutico, neste setor } \mathrm{a} \\
\text { Eurochain representa } 60 \% \text {." }\end{array}$ & 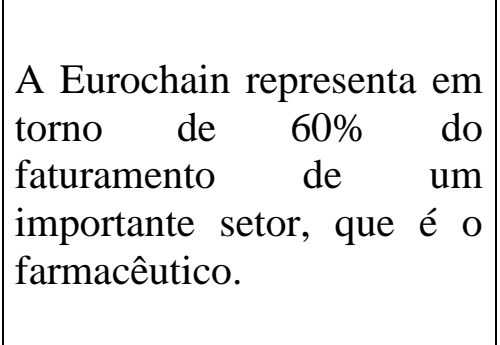 & $\begin{array}{l}\text { Eurochain } \\
\text { concentra } \\
\text { mais poder }\end{array}$ \\
\hline
\end{tabular}

Conclusão final: Resultado Final: 3 itens elegem a Eurochain e 1 item elege a Sul Deste Cargo, assim a Eurochain concentra fortemente o poder na relação.

\subsubsection{Relacionamento Sul Deste Cargo - Transportadores}

\begin{tabular}{|c|l|l|l|}
\hline Critérios & $\begin{array}{l}\text { Trechos da Entrevista, Visitas e } \\
\text { Documentos }\end{array}$ & Análise & \multicolumn{1}{|c|}{ Resultado } \\
\hline Negociações & $\begin{array}{l}\text { "De nós para o nosso } \\
\text { transportador não há multas e } \\
\text { bônus." }\end{array}$ & $\begin{array}{l}\text { Embora seja dito que a Sul } \\
\text { "A nossa posição com os nossos Cargo seja mais } \\
\text { fornecedores já é mais pesado, } \\
\text { figorosa na negociação, não } \\
\text { existe evidência que } \\
\text { comprove isto. }\end{array}$ & Indiferente \\
\\
um pouco "top down".
\end{tabular}




\begin{tabular}{|c|c|c|c|}
\hline Autonomia & 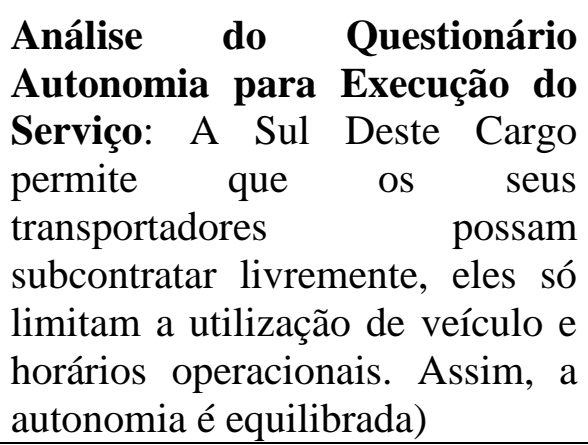 & $\begin{array}{l}\text { A Sul Deste Cargo permite } \\
\text { que os seus transportadores } \\
\text { possam subcontratar } \\
\text { livremente, eles só limitam } \\
\text { a utilização de veículo e } \\
\text { horários } \text { operacionais. } \\
\text { Assim, a autonomia é } \\
\text { equilibrada }\end{array}$ & Equilíbrio \\
\hline $\begin{array}{c}\text { Contexto } \\
\text { (aplicado a } \\
\text { todas as } \\
\text { dimensões) }\end{array}$ & $\begin{array}{l}\text { "Em São Paulo só temos um } \\
\text { fornecedor, e não temos muito } \\
\text { histórico, estamos com ele há } 6 \\
\text { meses e tem sido bom o nível de } \\
\text { serviço, anteriormente tínhamos } \\
\text { esse serviço feito pela própria Sul } \\
\text { Deste Cargo, não dependíamos } \\
\text { de outras empresas, mas agora o } \\
\text { volume aumentou." } \\
\text { "A princípio sim, temos } \\
\text { agregados e parceiros há mais de } \\
10 \text { anos trabalhando conosco." } \\
\text { "A nossa posição com os nossos } \\
\text { fornecedores já é mais pesado, } \\
\text { um pouco "top down"." } \\
\text { "Agregado compra combustível } \\
\text { mais barato na TA." }\end{array}$ & 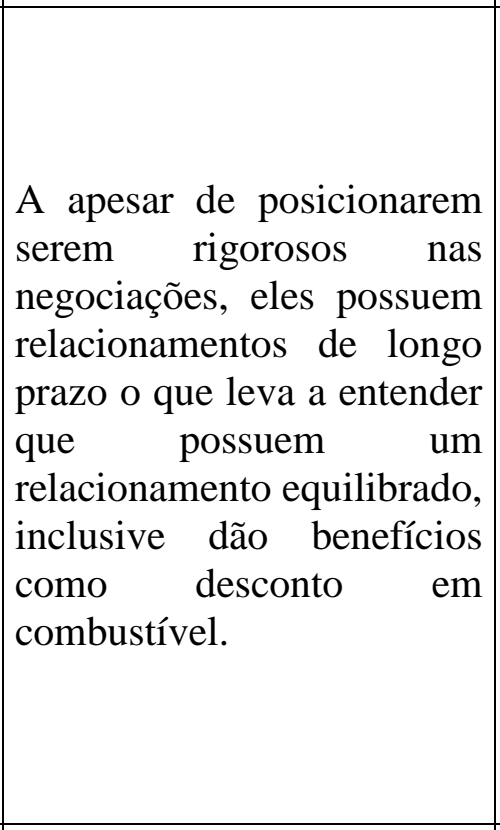 & Equilíbrio \\
\hline $\begin{array}{l}\text { *Importânci } \\
\text { a de uma } \\
\text { empresa } \\
\text { para a outra }\end{array}$ & "Todos são importantes" & $\begin{array}{l}\text { nenhuma } r \text { informação } \\
\text { relevante foi fornecida com } \\
\text { relação a volumes ou } \\
\text { estratégia ou número } \\
\text { restrito de fornecedores }\end{array}$ & $\begin{array}{l}\text { Desconside- } \\
\text { rado }\end{array}$ \\
\hline $\begin{array}{l}\text { *Participaçã } \\
\text { o no } \\
\text { faturamento }\end{array}$ & "Não sei dizer de cabeça." & $\begin{array}{l}\text { nenhuma } r \text { informação } \\
\text { relevante foi fornecida com } \\
\text { relação a volumes ou } \\
\text { estratégia ou número } \\
\text { restrito de fornecedores }\end{array}$ & $\begin{array}{c}\text { Desconside- } \\
\text { rado }\end{array}$ \\
\hline
\end{tabular}

Conclusão final: dos dois itens levados em consideração é possível observar equilíbrio nessas relações.

\subsubsection{Formalização}

\subsubsection{Relacionamento Sul Deste Cargo - Eurochain}

\begin{tabular}{|c|l|l|l|}
\hline Critérios & \multicolumn{1}{|c|}{$\begin{array}{c}\text { Trechos da Entrevista, Visitas e } \\
\text { Documentos }\end{array}$} & Análise & Resultado \\
\hline $\begin{array}{c}\text { Preços definidos e } \\
\text { formalizados? }\end{array}$ & $\begin{array}{l}\text { *- Tabelas de preços com custos por região } \\
\text { e peso, além de indicadores pelos quais } \\
\text { serão cobrados. }\end{array}$ & $\begin{array}{l}\text { Preços } \\
\text { formalizados. }\end{array}$ & Formal \\
\hline
\end{tabular}




\begin{tabular}{|c|c|c|c|}
\hline $\begin{array}{l}\text { Níveis de serviços } \\
\text { estão acordados e } \\
\text { formalizados? }\end{array}$ & $\begin{array}{l}\text { *- Controle interno de nível de serviço no } \\
\text { Excel; relatório de performance por filial e } \\
\text { por nota fiscal. (meta de } 98 \% \text { ) }\end{array}$ & $\begin{array}{l}\text { Níveis } \\
\text { formalizados } \\
\text { nos controles }\end{array}$ & Formal \\
\hline $\begin{array}{l}\text { Acompanhamento } \\
\text { do nível de } \\
\text { serviço? }\end{array}$ & $\begin{array}{l}\text { *- Apresentação da reunião com a } \\
\text { Eurochain - } 11 \text { slides sobre performance de } \\
\text { entrega, avaria e faltas, canhotos e } \\
\text { informações de entrega, apresentados por } \\
\text { cliente e por destino, todos os laboratórios } \\
\text { juntos, pendências de ressarcimentos. } \\
\text { *-Ata de reunião Eurochain com Sul Deste } \\
\text { Cargo - relação de problemas operacionais }\end{array}$ & $\begin{array}{lr}\text { Atas } & \text { com } \\
\text { controles } & \text { do } \\
\text { nível } & \text { de } \\
\text { serviço. } & \end{array}$ & Formal \\
\hline $\begin{array}{l}\text { Existe uma } \\
\text { prática de } \\
\text { reuniões } \\
\text { operacionais } \\
\text { padrão entre } \\
\text { fornecedor e } \\
\text { cliente? }\end{array}$ & $\begin{array}{l}\text { *- Apresentação da reunião com a } \\
\text { Eurochain - } 11 \text { slides sobre performance de } \\
\text { entrega, avaria e faltas, canhotos e } \\
\text { informações de entrega, apresentados por } \\
\text { cliente e por destino, todos os laboratórios } \\
\text { juntos, pendências de ressarcimentos. } \\
\text { *-Ata de reunião Eurochain com Sul Deste } \\
\text { Cargo - relação de problemas operacionais }\end{array}$ & $\begin{array}{lr}\text { Atas } & \text { com } \\
\text { controles } & \text { do } \\
\text { nível } & \text { de } \\
\text { serviço. } & \end{array}$ & Formal \\
\hline $\begin{array}{c}\text { Existem regras } \\
\text { padronizadas com } \\
\text { relação aos riscos } \\
\text { de carga de alto } \\
\text { valor? }\end{array}$ & $\begin{array}{l}\text { *- Regras do Plano de Gerenciamento de } \\
\text { Risco são cadastradas no sistema - acusa } \\
\text { automaticamente quando sai uma carga } \\
\text { acima do valor permitido }- \text { (visualizado um } \\
\text { caso no dia da visita.) } \\
\text { *- Regras da Gerenciadora de Risco }\end{array}$ & 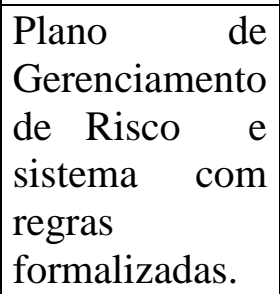 & Formal \\
\hline $\begin{array}{l}\text { Contexto } \\
\text { (aplicado a todas } \\
\text { as dimensões) }\end{array}$ & 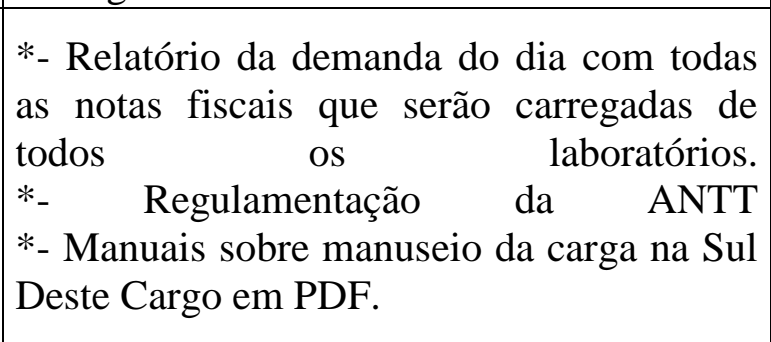 & $\begin{array}{l}\text { Apresentaram } \\
\text { outros } \\
\text { controles que } \\
\text { mostram } \\
\text { padronização } \\
\text { nos } \\
\text { procedimentos }\end{array}$ & Formal \\
\hline
\end{tabular}

Conclusão final: resultado Final: 6 itens demonstram que a Sul Deste Cargo é fortemente Formalizada.

5.7.4.2. Relacionamento Sul Deste Cargo - Transportadores

\section{Critérios}

\section{Trechos da Entrevista, Visitas e Documentos}

Análise

Resultado 


\begin{tabular}{|c|c|c|c|}
\hline $\begin{array}{c}\text { Preços definidos e } \\
\text { formalizados? }\end{array}$ & $\begin{array}{l}\text { Tabela de preços não foi } \\
\text { apresentada } \\
\text { *- Contrato de agregado } \\
\text { da Sul Deste Cargo; tipo } \\
\text { de r veículo, } \\
\text { responsabilidades } \\
\text { direitos, regras e } \\
\text { pagamento e seguro, } \\
\text { treinamentos necessários } \\
\text { e avaliação do veículo. } 9 \\
\text { páginas. }\end{array}$ & $\begin{array}{l}\text { Não sei se a tabela não foi } \\
\text { mostrada porque não havia } \\
\text { ou por sigilo de informação. } \\
\text { Embora a tabela não tivesse } \\
\text { sido mostrada, foi } \\
\text { apresentado o contrato com } \\
\text { o fornecedor, geralmente o } \\
\text { primeiro ponto a ser } \\
\text { assinado são os preços e por } \\
\text { último os contratos, logo é } \\
\text { muito provável que exista a } \\
\text { tabela de preços acordada. } \\
\text { Entretanto como não foi } \\
\text { visualizada essa dimensão } \\
\text { não será considerada. }\end{array}$ & Desconsiderado \\
\hline $\begin{array}{c}\text { Níveis de serviços } \\
\text { estão acordados e } \\
\text { formalizados? }\end{array}$ & $\begin{array}{l}\text { *- Controle interno de } \\
\text { nível de serviço no } \\
\text { Excel; relatório de } \\
\text { performance por filial e } \\
\text { por nota fiscal. } \\
\text { "Em São Paulo só temos } \\
\text { um fornecedor, e não } \\
\text { temos muito histórico, } \\
\text { estamos com ele há } 6 \\
\text { meses e tem sido bom o } \\
\text { nível de serviço, } \\
\text { anteriormente tínhamos } \\
\text { esse serviço feito pela } \\
\text { própria Sul Deste Cargo, } \\
\text { não dependíamos de } \\
\text { outras empresas, mas } \\
\text { agora o volume } \\
\text { aumentou." }\end{array}$ & $\begin{array}{l}\text { A Sul Deste Cargo sabe de } \\
\text { sua meta de 98\%, pois } \\
\text { foram evidênciadas nas } \\
\text { apresentações } \\
\text { performance. Existe um } \\
\text { controle de performance do } \\
\text { fornecedor e reuniões, } \\
\text { porém em nenhum } \\
\text { documento foi observado } \\
\text { explicitamente a meta do } \\
\text { nível de serviço de } 98 \% \\
\text { para o fornecedor. }\end{array}$ & Informal \\
\hline $\begin{array}{c}\text { Acompanhamento } \\
\text { do nível de } \\
\text { serviço? }\end{array}$ & $\begin{array}{l}\text { "Mensal, cada filial é } \\
\text { responsável pelos seus } \\
\text { fornecedores." } \\
\text { (acompanhamento } \\
\text { mensal) } \\
\text { "Faço reuniões mensais } \\
\text { com ele, pois é só um." } \\
\text { *- Controle interno de } \\
\text { nível de serviço no } \\
\text { Excel; relatório de } \\
\text { performance por filial e } \\
\text { por nota fiscal. } \\
\end{array}$ & $\begin{array}{l}\text { O controle interno foi } \\
\text { verificado, o entrevista } \\
\text { apresentou o arquivo excel, } \\
\text { porém este não detalhava o } \\
\text { transportador, mas sim toda } \\
\text { a filial }\end{array}$ & Informal \\
\hline $\begin{array}{l}\text { Existe uma } \\
\text { prática de } \\
\text { reuniões } \\
\text { operacionais } \\
\text { padrão entre } \\
\text { fornecedor e }\end{array}$ & \begin{tabular}{|lrr} 
"Faço reuniões & mensais \\
com ele, pois é só um." \\
$*_{--}$Reunião r com \\
fornecedor dele é mais \\
informal, não existe ata \\
ou & relatório.
\end{tabular} & $\begin{array}{l}\text { Eram feitas reuniões, mas } \\
\text { não haviam atas. } \\
\text { Em geral o controle de } \\
\text { agregados é menos rigoroso } \\
\text { que o controle de empresas. } \\
\text { Entretanto foi mostrado }\end{array}$ & Informal \\
\hline
\end{tabular}




\begin{tabular}{|c|c|c|c|}
\hline cliente? & \begin{tabular}{|lr}
$*_{-} \quad$ Relatório de \\
Agregados \\
problemas - nome do \\
agregado e ocorrência
\end{tabular} & $\begin{array}{l}\text { documentos que } \\
\text { controlavam problemas } \\
\text { operacionais de agregados, } \\
\text { logo é muito possível que } \\
\text { existam controles só quando } \\
\text { existam problemas. Mas por } \\
\text { enquanto é informal. }\end{array}$ & \\
\hline $\begin{array}{l}\text { Existem regras } \\
\text { padronizadas com } \\
\text { relação aos riscos } \\
\text { de carga de alto } \\
\text { valor? }\end{array}$ & $\begin{array}{l}\text { *_ }_{\text {- Regras }} \text { da } \\
\text { Gerenciadora de Risco } \\
\text { "Sim, possuímos nossas } \\
\text { regras de operação com o } \\
\text { nosso fornecedor por } \\
\text { escrito." }\end{array}$ & 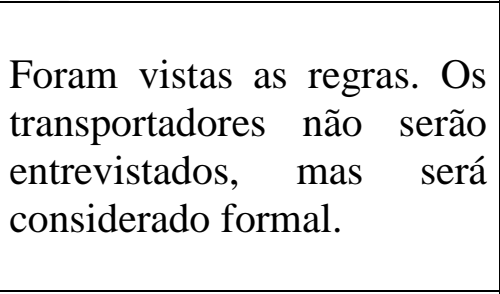 & Formal \\
\hline $\begin{array}{c}\text { Contexto } \\
\text { (aplicado a todas } \\
\text { as dimensões) }\end{array}$ & 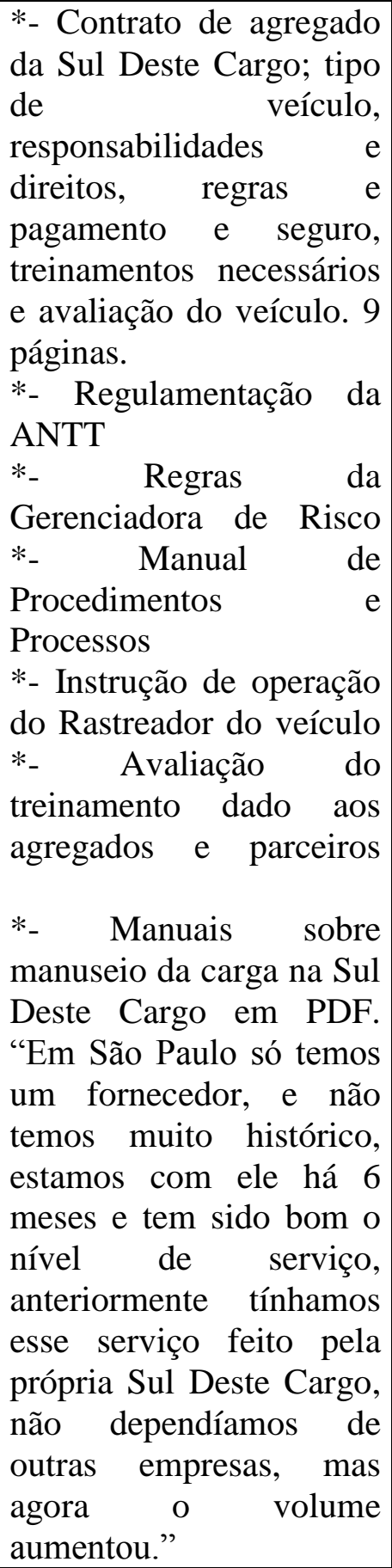 & $\begin{array}{l}\text { A Sul Deste Cargo possui } \\
\text { diversos controles e um } \\
\text { sistema robusto para regras } \\
\text { de gerenciamento de risco. } \\
\text { Eles só possuem um } \\
\text { fornecedor em São Paulo } \\
\text { que foi o alvo da pesquisa, e } \\
\text { este estão com eles há } 6 \\
\text { meses. Neste caso embora } \\
\text { alguns controles não tenha } \\
\text { sido evidenciados, os outros } \\
\text { controles e o curto período } \\
\text { de tempo, justificam que } \\
\text { seja classificado como } \\
\text { formal neste critério. }\end{array}$ & Formal \\
\hline
\end{tabular}


Conclusão final: 3 critérios considerados informais, 2 critério considerado formal. Análise final, levemente informal, apesar disso o ponto crítico que são as regras de risco, estas estão formalizadas.

\subsubsection{Integração}

5.7.5.1. Relacionamento Sul Deste Cargo - Eurochain

\begin{tabular}{|c|c|c|c|}
\hline Critérios & $\begin{array}{c}\text { Trechos da Entrevista, Visitas e } \\
\text { Documentos }\end{array}$ & Análise & Resultado \\
\hline $\begin{array}{l}\text { Iniciativas em } \\
\text { conjunto que } \\
\text { proporcionem } \\
\text { benefícios para } \\
\text { ambas as } \\
\text { empresas }\end{array}$ & (Sem Evidências) & (Sem Evidências) & Sem Integração \\
\hline $\begin{array}{c}\text { Contexto } \\
\text { (aplicado a } \\
\text { todas as } \\
\text { dimensões) }\end{array}$ & - & $\begin{array}{l}\text { Não houve nenhuma } \\
\text { informação relevante } \\
\text { que não foi discutida } \\
\text { em outros critérios. } \\
\text { Desconsiderar }\end{array}$ & Desconsiderado \\
\hline *Comunicação & $\begin{array}{l}\text { "Falta comunicação interna entre } \\
\text { a operação e o time de } \\
\text { atendimento da Eurochain, ás } \\
\text { vezes a operação me pede para } \\
\text { segurar uma entrega, mas depois } \\
\text { sou cobrado do atraso dessa } \\
\text { entrega, mas foram eles mesmos } \\
\text { que pediram para eu bloquear a } \\
\text { entrega." } \\
\text { "As informações e previsões de } \\
\text { carga da Eurochain são muito } \\
\text { boas." }\end{array}$ & $\begin{array}{l}\text { Os dados operacionais } \\
\text { para planjamento são } \\
\text { bons, entretando a } \\
\text { desorganização } \\
\text { interna dos times } \\
\text { prejudica } \\
\text { comunicação. }\end{array}$ & Sem Integração \\
\hline *Confiança & $\begin{array}{l}\text { "A Sul Deste Cargo não pode } \\
\text { falar com a Cialab por clausula } \\
\text { contratual, porém pode falar com } \\
\text { os distribuidores para fazer o } \\
\text { agendamento da carga." }\end{array}$ & $\begin{array}{l}\text { Falta de confiança, a } \\
\text { Eurochain enxerga a } \\
\text { Sul Deste Cargo como } \\
\text { possível competidor }\end{array}$ & Sem Integração \\
\hline $\begin{array}{c}* \text { Tempo de } \\
\text { relacionamento }\end{array}$ & "Há mais de 10 anos." & $\begin{array}{l}\text { Relacionamento de } \\
\text { longo prazo }\end{array}$ & Integração \\
\hline
\end{tabular}


Conclusão final: Resultado Final: 3 itens demonstram fortemente a falta de integração entre Sul Deste Cargo e a Eurochain .

\subsubsection{Relacionamento Sul Deste Cargo - Transportadores}

\begin{tabular}{|c|c|c|c|}
\hline Critérios & $\begin{array}{c}\text { Trechos da Entrevista, Visitas e } \\
\text { Documentos }\end{array}$ & Análise & Resultado \\
\hline $\begin{array}{l}\text { Iniciativas em } \\
\text { conjunto que } \\
\text { proporcionem } \\
\text { benefícios } \\
\text { para ambas as } \\
\text { empresas }\end{array}$ & $\begin{array}{l}\text { "Já fizemos parcerias com } \\
\text { concorrentes nossos para trazer } \\
\text { carga deles em casos onde nossos } \\
\text { veículos fariam uma viagem com o } \\
\text { veículo vazio e vice-versa." } \\
\text { "Neste caso foi indicação de outros } \\
\text { concorrentes com quem mantemos } \\
\text { bom relacionamento." }\end{array}$ & $\begin{array}{l}\text { Apesar de já terem } \\
\text { ocorrido iniciativas } \\
\text { colaborativas, nenhuma } \\
\text { dessas empresas era da } \\
\text { cadeia. }\end{array}$ & $\begin{array}{c}\text { Sem } \\
\text { Integração }\end{array}$ \\
\hline $\begin{array}{l}\text { Contexto } \\
\text { (aplicado a } \\
\text { todas as } \\
\text { dimensões) }\end{array}$ & ( & $\begin{array}{l}\text { Não houve nenhuma } \\
\text { informação relevante } \\
\text { que não foi discutida } \\
\text { em outros critérios. } \\
\text { Desconsiderar }\end{array}$ & $\begin{array}{l}\text { Desconside- } \\
\text { rado }\end{array}$ \\
\hline $\begin{array}{c}\text { *Comunicaçãa } \\
\mathbf{0}\end{array}$ & $\begin{array}{l}\text { "Faço reuniões mensais com ele, } \\
\text { pois é } \\
\text { *-- Reunião com fornecedor dele é } \\
\text { mais informal, não existe ata ou } \\
\text { relatório. }\end{array}$ & $\begin{array}{lr}\text { Reuniões } & \text { puramente } \\
\text { operacionais, } & \text { pouco } \\
\text { histórico } & \text { de } \\
\text { relacionamento } & \end{array}$ & $\begin{array}{c}\text { Sem } \\
\text { Integração }\end{array}$ \\
\hline *Confiança & Sem evidências & $\begin{array}{l}\text { Não houve nenhuma } \\
\text { informação relevante } \\
\text { que não foi discutida } \\
\text { em outros critérios. } \\
\text { Desconsiderar }\end{array}$ & $\begin{array}{l}\text { Desconside- } \\
\text { rado }\end{array}$ \\
\hline $\begin{array}{l}\text { * Tempo de } \\
\text { relacionamen- } \\
\text { to }\end{array}$ & $\begin{array}{l}\text { "Em São Paulo só temos um } \\
\text { fornecedor, e não temos muito } \\
\text { histórico, estamos com ele há } 6 \\
\text { meses e tem sido bom o nível de } \\
\text { serviço, anteriormente tínhamos } \\
\text { esse serviço feito pela própria Sul } \\
\text { Deste Cargo, não dependíamos de } \\
\text { outras empresas, mas agora o } \\
\text { volume aumentou." }\end{array}$ & 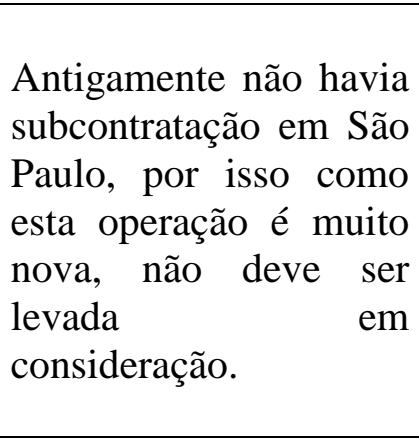 & $\begin{array}{l}\text { Desconside- } \\
\text { rado }\end{array}$ \\
\hline
\end{tabular}

Conclusão Final: 2 itens demonstram fortemente a falta de integração entre Sul Deste Cargo e a seus fornecedores. 


\subsubsection{Centralização}

\subsubsection{Relacionamento Sul Deste Cargo - Eurochain}

\begin{tabular}{|c|c|c|c|}
\hline Critérios & $\begin{array}{c}\text { Trechos da Entrevista, Visitas e } \\
\text { Documentos }\end{array}$ & Análise & Resultado \\
\hline Negociações & $\begin{array}{l}\text { "Só existe bônus e multas entre a Indústria } \\
\text { e nos operadores logísticos, implantamos } \\
\text { isso há } 2 \text { meses. Nós nunca recebemos } \\
\text { bônus por algum fator interno do } \\
\text { Operador Logístico, só pagamos. } \\
\text { Sim(multas e bônus), foi implementada há } \\
2 \text { meses." } \\
\text { (Entrevistados } 1 \text { e 2) }\end{array}$ & $\begin{array}{l}\text { Conforme } \\
\text { entrevistado } 1 \text { e } 2 \\
\text { explicaram neste } \\
\text { processo de multa e } \\
\text { bônus, a Eurochain } \\
\text { não recebe bonus por } \\
\text { decisão própria e não } \\
\text { por imposição da } \\
\text { Cialab. A princípio } \\
\text { haveria multa mais o } \\
\text { bônus, ou seja, seria } \\
\text { uma regra que } \\
\text { beneficia os dois } \\
\text { lados. }\end{array}$ & Equilíbrio \\
\hline Autonomia & 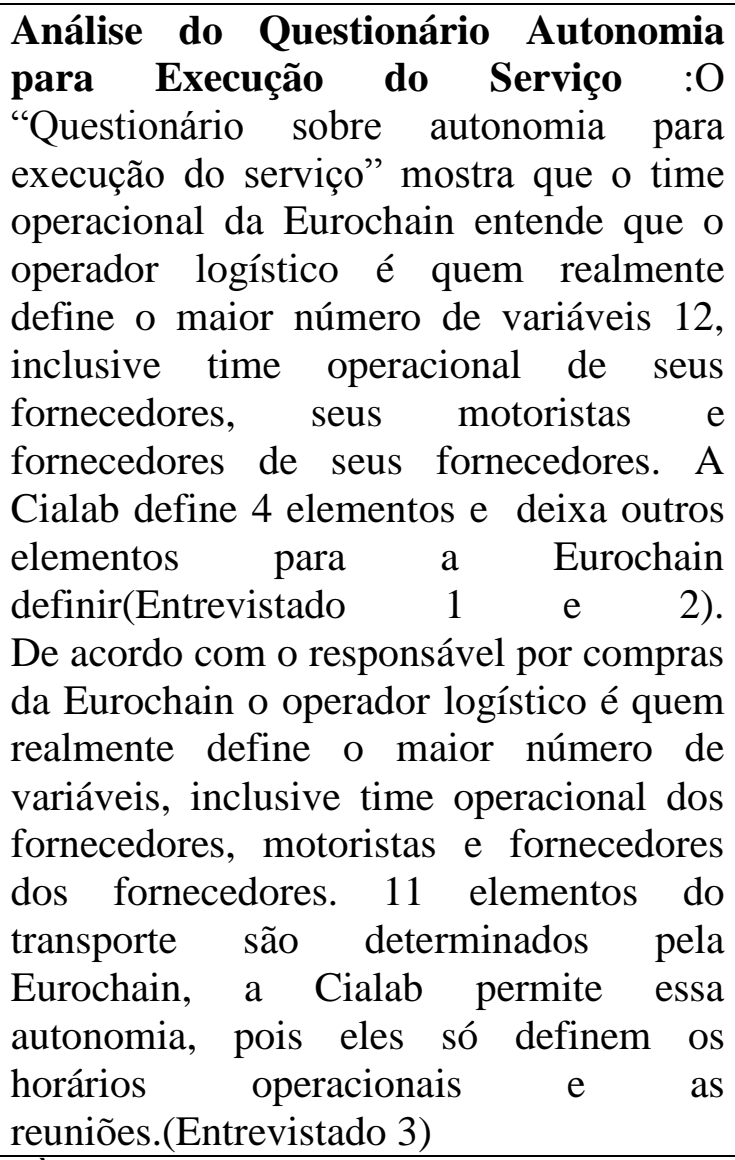 & $\begin{array}{l}\text { A Eurochain possuiu } \\
\text { autonomia sobre os } \\
\text { elementos } \\
\text { operacionais do } \\
\text { serviço de transporte } \\
\text { na cadeia. }\end{array}$ & $\begin{array}{l}\text { Eurochain } \\
\text { concentra } \\
\text { mais poder }\end{array}$ \\
\hline $\begin{array}{l}\text { Contexto } \\
\text { (aplicado a } \\
\text { todas as } \\
\text { dimensões) }\end{array}$ & $\begin{array}{l}\text { "Às vezes aparecem demandas que não } \\
\text { temos como cumprir, nesse caso após } \\
\text { justificarmos bem, o cliente compreende } \\
\text { os riscos e a inviabilidade, ou seja, temos } \\
\text { um diálogo aberto". (Entrevistados } 1 \text { e } 2 \text { ) }\end{array}$ & $\begin{array}{l}\text { Mostra um diálogo } \\
\text { aberto entre as duas } \\
\text { empresas. }\end{array}$ & Equilíbrio \\
\hline
\end{tabular}




\begin{tabular}{|c|c|c|c|}
\hline $\begin{array}{c}\text { *Importân- } \\
\text { cia de uma } \\
\text { empresa } \\
\text { para a outra }\end{array}$ & $\begin{array}{l}\text { "É um cliente muito importante devido ao } \\
\text { tamanho da conta, quando temos } \\
\text { problemas com este cliente um grande } \\
\text { número de pessoas na alta hierarquia é } \\
\text { envolvida." (Entrevistados 1 e 2) } \\
\text { "Estamos muito satisfeitos, é uma } \\
\text { operação de benchmarking, uma conta } \\
\text { boa. Nesta operação desenvolvemos } \\
\text { inovações, existe uma troca para os dois } \\
\text { lados." (Entrevistados 1 e 2) } \\
\text { "Eles são o que chamamos de cliente } \\
\text { chave, muito importante".(Entrevistados } \\
\text { 3) } \\
\text { "Sim é lucrativa."(Entrevistados 3) }\end{array}$ & 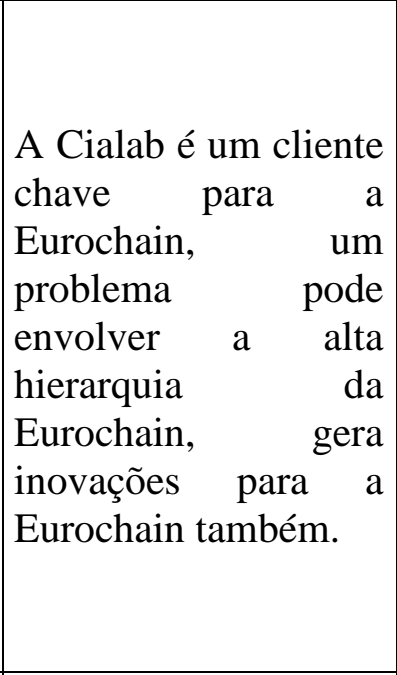 & $\begin{array}{c}\text { Cialab } \\
\text { concentra } \\
\text { mais poder }\end{array}$ \\
\hline $\begin{array}{c}\text { *Participa- } \\
\text { ção no } \\
\text { faturamento }\end{array}$ & $\begin{array}{l}\text { "O faturamento em transportes no setor } \\
\text { farmacêutico é em torno de } \mathrm{R} \$ 150 \\
\text { milhões por ano aproximadamente." } \\
\text { (Entrevistados } \\
\text { "Esse cliente representa em torno de } 25 \% \\
\text { do nosso faturamento do setor } \\
\text { Farmacêutico."(Entrevistados } 1 \text { e } 2) \\
\text { "A Cialab deve representar em torno de } \\
25 \% \text { de todo o nosso faturamento do setor } \\
\text { farmacêutico. Esse setor dentro da área de } \\
\text { transportes corresponde a } 25 \% \text { do total." } \\
\text { Entrevistados 3) }\end{array}$ & $\begin{array}{l}\text { A Cialab corresponde } \\
\text { a } 1 / 4 \text { do faturamento } \\
\text { do setor farmacêutico } \\
\text { da Eurochain, é uma } \\
\text { contar muito } \\
\text { importanter }\end{array}$ & $\begin{array}{c}\text { Cialab } \\
\text { concentra } \\
\text { mais poder }\end{array}$ \\
\hline
\end{tabular}

Conclusão final: 2 itens elegem a Cialab e 1 item elege a Eurochain, assim a Cialab concentra levemente o poder na relação. 


\subsubsection{Relacionamento Eurochain - Transportadores}

\begin{tabular}{|c|c|c|c|}
\hline Critérios & Trechos da Entrevista, Visitas e Documentos & Análise & Resultado \\
\hline Negociações & $\begin{array}{l}\text { "Nosso relacionamento é bom. Embora quando } \\
\text { existem problemas de falta, caso o transportador } \\
\text { não justifique o custo de ressarcimento é dele." } \\
\text { (Entrevistados } \\
\text { "O relacionamento não é "Top-Down", ditatorial, } \\
\text { nos negociamos, tentamos, por exemplo, em alguns } \\
\text { casos colocar o pagamento atrelado ao retorno dos } \\
\text { canhotos de entrega, porém o transportador não } \\
\text { aceitou e ficamos sem essa alteração do processo. } \\
\text { Às vezes damos uma forçada para chegar a um } \\
\text { meio termo." (Entrevistados } 1 \text { e } 2 \text { ) } \\
\text { "Atualmente estão mais satisfeitos." (os } \\
\text { fornecedores) "Antigamente tínhamos problemas } \\
\text { na separação da carga e quando havia divergências } \\
\text { que o transportador não conseguia justificar ele que } \\
\text { tinha que arcar com esses custos, como a } \\
\text { mercadoria é de alto valor, isso era crítico com o } \\
\text { transportador. Hoje em dia este problema está bem } \\
\text { menor. " (Entrevistados } 1 \text { e 2) }\end{array}$ & $\begin{array}{l}\text { Os } \\
\text { entrevistados } \\
1 \text { e } 2 \text { dizem } \\
\text { que não são } \\
\text { ditadores, } \\
\text { mas que dão } \\
\text { uma forçada, } \\
\text { também } \\
\text { citou } 2 \text { vezes } \\
\text { que se o } \\
\text { fornecedor } \\
\text { não an } \\
\text { conseguir } \\
\text { provar a } \\
\text { culpa já é } \\
\text { dele, e ele } \\
\text { terá de } \\
\text { ressarcir, ou } \\
\text { seja, é o elo } \\
\text { mais fraco. }\end{array}$ & $\begin{array}{l}\text { Eurochain } \\
\text { concentra } \\
\text { mais poder }\end{array}$ \\
\hline Autonomia & 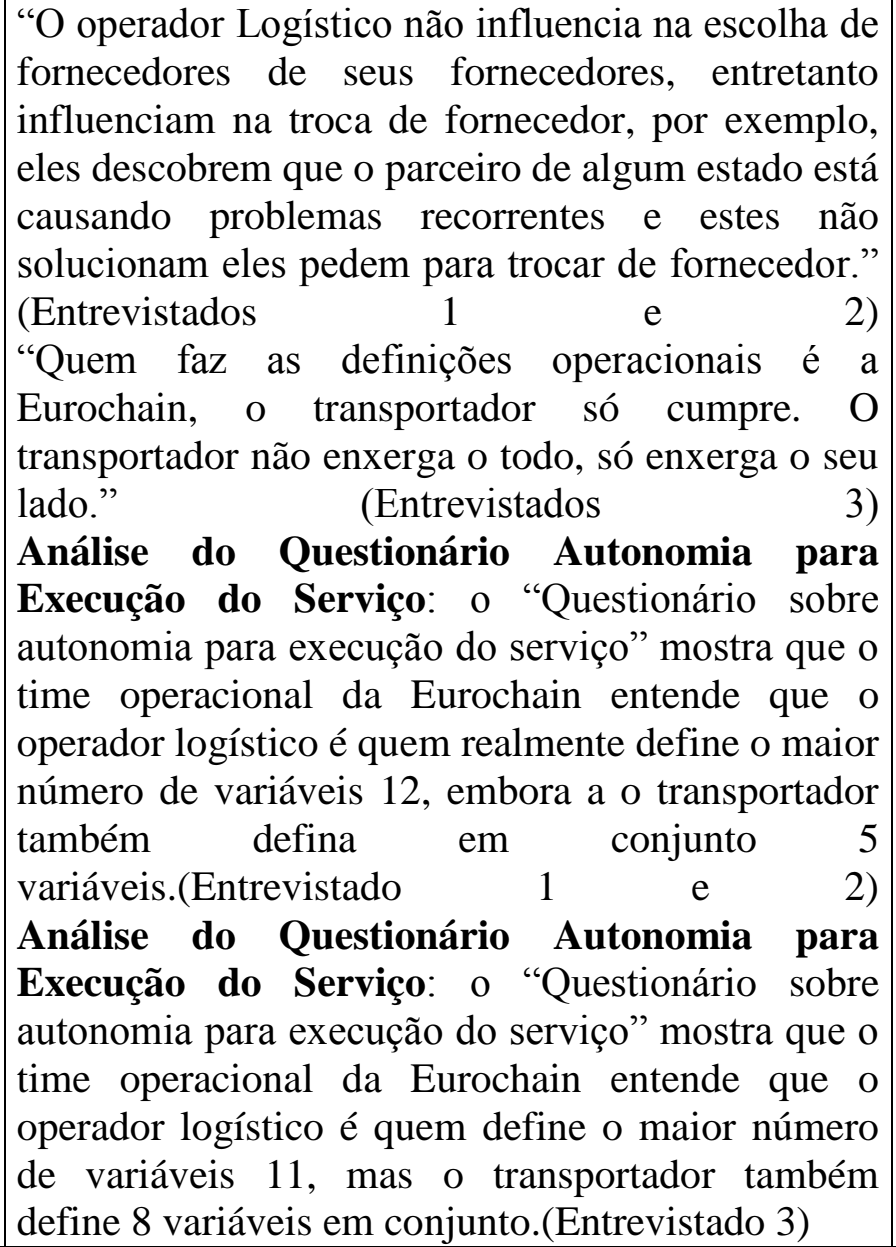 & $\begin{array}{l}\text { Embora o } \\
\text { transportado } \\
\mathrm{r} \text { tenha } \\
\text { algumas } \\
\text { opções de } \\
\text { escolha } \\
\text { operacional, } \\
\text { quem define } \\
\text { a maior parte } \\
\text { dos } \\
\text { elementos da } \\
\text { operação é a } \\
\text { Eurochain. } \\
\text { Inclusive } \\
\text { pode pedir } \\
\text { para trocar } \\
\text { um fornecedor } \\
\text { fornetara } \\
\text { contratado } \\
\text { pela Sul } \\
\text { Deste Cargo }\end{array}$ & $\begin{array}{l}\text { Eurochain } \\
\text { concentra } \\
\text { mais poder }\end{array}$ \\
\hline $\begin{array}{c}\text { Contexto } \\
\text { (aplicado a }\end{array}$ & "Em torno de 80 transportadores. (Entrevistados 1 & $\begin{array}{l}\text { A Eurochain } \\
\text { possui um }\end{array}$ & Equilíbrio \\
\hline
\end{tabular}




\begin{tabular}{|c|c|c|c|}
\hline $\begin{array}{c}\text { todas as } \\
\text { dimensões) }\end{array}$ & $\begin{array}{l}\text { e } \\
\text { Creio que em média os transportadores devem estar } \\
\text { trabalhando conosco há } 6 \text { anos, temos alguns com } \\
15 \text { anos". (Entrevistados } 1 \text { e } 2 \text { ) }\end{array}$ & $\begin{array}{|lr|}\text { foco } & \text { de } \\
\text { longo } & \text { prazo } \\
\text { nos } & \\
\text { relacioname } \\
\text { ntos, r mas } \\
\text { possuiu } & \\
\text { diversas } & \\
\text { opções } & \text { de } \\
\text { transportado } \\
\text { res em } & \text { torno } \\
\text { de } 80 & \\
\end{array}$ & \\
\hline $\begin{array}{l}\text { *Importân- } \\
\text { cia de uma } \\
\text { empresa } \\
\text { para a outra }\end{array}$ & $\begin{array}{l}\text { "Nível de serviço ou Custo. Às vezes o } \\
\text { transportador pede reajuste de } 30 \% \text { ou ameaça de } \\
\text { ir embora. Quando o problema é nível de serviço a } \\
\text { última opção é cortar o fornecedor, tentamos } \\
\text { fortemente desenvolvê-lo. É muito complexo trocar } \\
\text { de fornecedores, pois sempre temos um grande } \\
\text { trabalho de transferência de conhecimento para o } \\
\text { fornecedor, atualmente o mercado está escasso de } \\
\text { bons fornecedores, não se encontra fornecedores } \\
\text { bem preparados." (Entrevistados 3) }\end{array}$ & 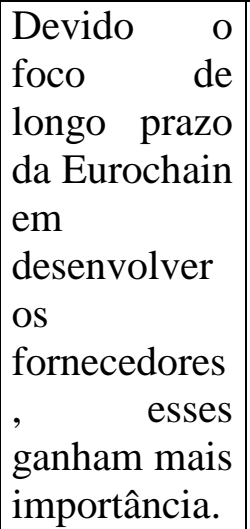 & Equilíbrio \\
\hline $\begin{array}{l}\text { *Participa- } \\
\text { ção no } \\
\text { faturamento }\end{array}$ & $\begin{array}{l}\text { "O total de carga para a região sul e sudeste é } \\
\text { equivalente a } 25 \% \text { do total de carga Cialab no } \\
\text { país." (Entrevistados } 1 \text { e } 1 \text { 2) } \\
\text { "O total levado pelo transportador Sul Deste Cargo } \\
\text { é de } 10 \% \text { deste total, ou seja, } 2,5 \% \text { do total } \\
\text { Cialab." (Entrevistados } 1 \text { e } 2 \text { ) }\end{array}$ & 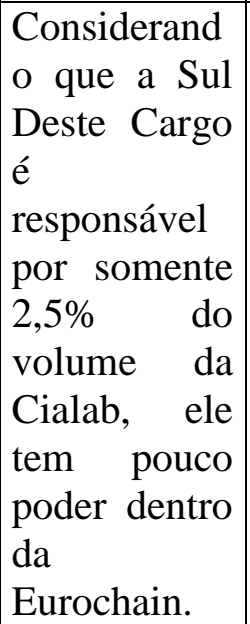 & $\begin{array}{l}\text { Eurochain } \\
\text { concentra } \\
\text { mais poder }\end{array}$ \\
\hline
\end{tabular}

Conclusão final: dos cinco critérios levados em consideração, 3 consideram a Eurochain como concentrador de poder, e nenhum considera a Sul Deste Cargo. Assim, a Eurochain concentra fortemente o poder na relação.

\subsubsection{Relacionamento Eurochain - Air Cargo}

\begin{tabular}{|c|c|c|c|}
\hline Critérios & Trechos da Entrevista, Visitas e Documentos & Análise & Resultado \\
\hline Negociações & $\begin{array}{l}\text { "Nosso relacionamento é bom. Embora quando } \\
\text { existem problemas de falta, caso o transportador } \\
\text { não justifique o custo de ressarcimento é dele." } \\
\text { (Entrevistados } \\
\text { "O relacionamento não é "Top-Down", ditatorial, } \\
\text { nós negociamos, tentamos, por exemplo em alguns } \\
\text { casos colocar o pagamento atrelado ao retorno dos }\end{array}$ & $\begin{array}{l}\text { Os } \\
\text { entrevistados } \\
1 \text { e } 2 \text { dizem } \\
\text { que não são } \\
\text { ditadores, } \\
\text { mas que dão } \\
\text { uma forçada, }\end{array}$ & $\begin{array}{l}\text { Eurochain } \\
\text { concentra } \\
\text { mais poder }\end{array}$ \\
\hline
\end{tabular}




\begin{tabular}{|c|c|c|c|}
\hline & $\begin{array}{l}\text { canhotos de entrega, porém o transportador não } \\
\text { aceitou e ficamos sem essa alteração do processo. } \\
\text { Âs vezes damos uma forçada para chegar a um } \\
\text { meio termo." (Entrevistados } 1 \text { e } \\
\text { "Atualmente estão mais satisfeitos (os } \\
\text { fornecedores). Antigamente tínhamos problemas } \\
\text { na separação da carga e quando havia divergências } \\
\text { que o transportador não conseguia justificar ele que } \\
\text { tinha que arcar com esses custos, como a } \\
\text { mercadoria é de alto valor, isso era crítico com o } \\
\text { transportador. Hoje em dia este problema está bem } \\
\text { menor." (Entrevistados } 1 \text { e } 2 \text { ) }\end{array}$ & $\begin{array}{l}\text { também } \\
\text { citou } 2 \text { vezes } \\
\text { que se o } \\
\text { fornecedor } \\
\text { não } \\
\text { conseguir } \\
\text { provar a } \\
\text { culpa já é } \\
\text { dele, e ele } \\
\text { terá de } \\
\text { ressarcir, ou } \\
\text { seja, é o elo } \\
\text { mais fraco. }\end{array}$ & \\
\hline Autonomia & 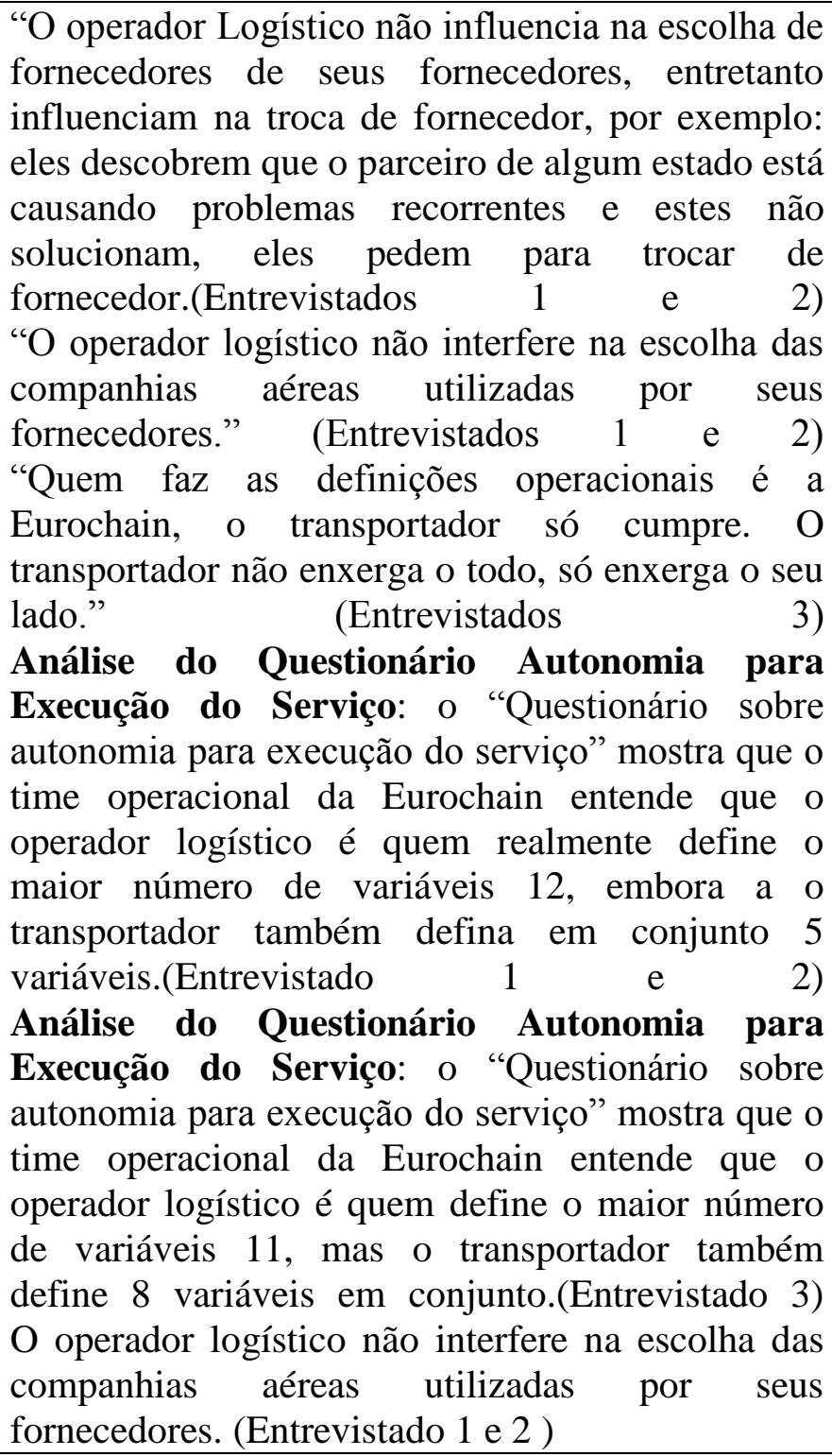 & $\begin{array}{l}\text { Embora o } \\
\text { transportado } \\
\mathrm{r} \text { tenha } \\
\text { algumas } \\
\text { opções de } \\
\text { escolha } \\
\text { operacional, } \\
\text { quem define } \\
\text { a maior parte } \\
\text { dos } \\
\text { elementos da } \\
\text { operação é a } \\
\text { Eurochain. } \\
\text { Inclusive } \\
\text { pode pedir } \\
\text { para trocar } \\
\text { um fornecedor } \\
\text { fornet } \\
\text { contratado } \\
\text { pela Air } \\
\text { Cargo }\end{array}$ & $\begin{array}{l}\text { Eurochain } \\
\text { concentra } \\
\text { mais poder }\end{array}$ \\
\hline
\end{tabular}




\begin{tabular}{|c|c|c|c|}
\hline $\begin{array}{l}\text { Contexto } \\
\text { (aplicado a } \\
\text { todas as } \\
\text { dimensões) }\end{array}$ & $\begin{array}{l}\text { "Em torno de } 80 \text { transportadores." (Entrevistados } 1 \\
\text { e } \\
\text { "Creio que em média os transportadores devem } \\
\text { estar trabalhando conosco há } 6 \text { anos, temos alguns } \\
\text { com } 15 \text { anos." (Entrevistados } 1 \text { e } 2 \text { ) }\end{array}$ & $\begin{array}{l}\text { A Eurochain } \\
\text { possui um } \\
\text { foco de } \\
\text { longo prazo } \\
\text { nos } \\
\text { relacioname } \\
\text { ntos, mas } \\
\text { possuiu } \\
\text { diversas } \\
\text { opções de } \\
\text { transportado } \\
\text { res em torno } \\
\text { de } 80\end{array}$ & Equilíbrio \\
\hline $\begin{array}{l}\text { *Importânci } \\
\text { a de uma } \\
\text { empresa } \\
\text { para a outra }\end{array}$ & $\begin{array}{l}\text { "Nível de serviço ou Custo. Às vezes o } \\
\text { transportador pede reajuste de } 30 \% \text { ou ameaça de } \\
\text { ir embora. Quando o problema é nível de serviço a } \\
\text { última opção é cortar o fornecedor. Tentamos } \\
\text { fortemente desenvolvê-lo. É muito complexo trocar } \\
\text { de fornecedores, pois sempre temos um grande } \\
\text { trabalho de transferência de conhecimento para o } \\
\text { fornecedor, atualmente o mercado está escasso de } \\
\text { bons fornecedores, não se encontra fornecedores } \\
\text { bem preparados." (Entrevistados } 3 \text { ) }\end{array}$ & $\begin{array}{l}\text { Devido o } \\
\text { foco de } \\
\text { longo prazo } \\
\text { da Eurochain } \\
\text { em } \\
\text { desenvolver } \\
\text { os } \\
\text { fornecedores } \\
\text {, esses } \\
\text { ganham mais } \\
\text { importância. }\end{array}$ & Equilíbrio \\
\hline $\begin{array}{l}\text { *Participaçã } \\
\text { o no } \\
\text { faturamento }\end{array}$ & $\begin{array}{l}\text { "O total de carga aérea da Cialab representa uns } \\
20 \% \text { do total da carga. Desses 20\%, 90\% são } \\
\text { transportados pela Air Cargo." (Entrevistado } 1 \text { e 2) }\end{array}$ & $\begin{array}{l}\text { Considerand } \\
\text { o que a Air } \\
\text { Cargo é } \\
\text { responsável } \\
\text { por somente } \\
90 \% \text { do } \\
\text { volume } \\
\text { aéreo do } \\
\text { Farmacêutic } \\
\text { o, não só da } \\
\text { Cialab, eles } \\
\text { possuem } \\
\text { muita } \\
\text { influência na } \\
\text { Eurochain. }\end{array}$ & $\begin{array}{l}\text { Air Cargo } \\
\text { concentra } \\
\text { mais poder }\end{array}$ \\
\hline
\end{tabular}

Conclusão final: Dos cinco critérios levados em consideração, 2 consideram a Eurochain como concentrador de poder, e um considera a Air Cargo. Assim, a Eurochain concentra levemente o poder na relação. 


\subsubsection{Relacionamento Cialab - Eurochain}

\begin{tabular}{|c|c|c|c|}
\hline Critérios & $\begin{array}{l}\text { Trechos da Entrevista, Visitas e } \\
\text { Documentos }\end{array}$ & Análise & Resultado \\
\hline $\begin{array}{l}\text { Preços definidos } \\
\text { e formalizados? }\end{array}$ & $\begin{array}{l}\text { "Tabela de preço para modal aéreo: tabela de } \\
\text { preços que considera a variação de peso, } \\
\text { destino e valor de mercadoria." } \\
(\text { Entrevistados } 1 \text { e } 2)\end{array}$ & $\begin{array}{l}\text { Tabela de } \\
\text { preços } \\
\text { apresentada. }\end{array}$ & Formal \\
\hline $\begin{array}{l}\text { Níveis de } \\
\text { serviços estão } \\
\text { acordados e } \\
\text { formalizados? }\end{array}$ & $\begin{array}{l}\text { "Tabela de Prazos de entrega: tabela com } \\
\text { dias para entrega para cada região ou cidade } \\
\text { de destino." (Entrevistados } 1 \text { e } 2 \text { ) }\end{array}$ & $\begin{array}{l}\text { Tabela de } \\
\text { prazos } \\
\text { apresentada. }\end{array}$ & Formal \\
\hline $\begin{array}{l}\text { Acompanhamen- } \\
\text { to do nível de } \\
\text { serviço? }\end{array}$ & $\begin{array}{l}\text { *Apresentação da reunião entre Eurochain e } \\
\text { Cialab, tratava dos seguintes pontos: } \\
\text { Performance de entregas no prazo e } \\
\text { performance de avarias, causas de baixa } \\
\text { performance e identificação dos } \\
\text { responsáveis. Impactos da Copa do Mundo, } \\
\text { os Ressarcimentos a serem feitos a Indústria } \\
\text { Farmacêutica. Melhorias na Qualidade o } \\
\text { Acompanhamento de modalidade de entregas } \\
\text { específicas para pessoas físicas o } \\
\text { Agendamentos - tratamento especial para os } \\
\text { destinatários que precisam ter dia e horário } \\
\text { da entrega agendada, mais de } 70 \% \text { dos } \\
\text { clientes trabalham com este procedimento. }\end{array}$ & $\begin{array}{l}\text { Existem } \\
\text { relatórios de } \\
\text { performance } \\
\text { que } \\
\text { alimentaram } \\
\text { esta } \\
\text { apresentação } \\
\text { dos dados. }\end{array}$ & Formal \\
\hline $\begin{array}{l}\text { Existe uma } \\
\text { prática de } \\
\text { reuniões } \\
\text { operacionais } \\
\text { padrão entre } \\
\text { fornecedor e } \\
\text { cliente? }\end{array}$ & $\begin{array}{l}\text { *Apresentação para cliente da Reunião com } \\
\text { Cialab } \\
\text { * E-mail com a agenda da reunião mensal } \\
\text { entre Cialab e Eurochain: Definição dos } \\
\text { horários de reuniões diárias (em um a cada } 3 \\
\text { meses quando existe o fechamento trimestral } \\
\text { da Indústria Farmacêutica é realizado } \\
\text { reuniões por telefone diárias sobre o } \\
\text { andamento da operação). Discussão sobre } \\
\text { operação de carros dedicados ao Manuseio } \\
\text { da Carga ou problemas operacionais. } \\
\text { *Apresentação da reunião entre Eurochain e } \\
\text { Cialab, tratava dos seguintes pontos: } \\
\text { Performance de entregas no prazo e } \\
\text { performance de avarias, causas de baixa } \\
\text { performance e identificação dos } \\
\text { responsáveis; Impactos da Copa do Mundo o } \\
\text { Ressarcimentos a serem feitos a Indústria } \\
\text { Farmacêutica; Melhorias na Qualidade; } \\
\text { Acompanhamento de modalidade de entregas } \\
\text { específicas para pessoas físicas; } \\
\text { Agendamentos - tratamento especial para os } \\
\text { destinatários que precisam ter dia e horário }\end{array}$ & 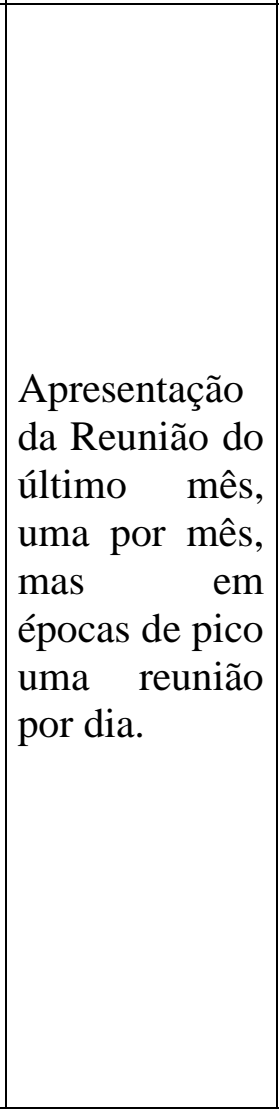 & Formal \\
\hline
\end{tabular}




\begin{tabular}{|c|c|c|c|}
\hline & $\begin{array}{l}\text { da entrega agendada, mais de } 70 \% \text { dos } \\
\text { clientes trabalham com este procedimento. }\end{array}$ & & \\
\hline $\begin{array}{l}\text { Existem regras } \\
\text { padronizadas } \\
\text { com relação aos } \\
\text { riscos de carga } \\
\text { de alto valor? }\end{array}$ & $\begin{array}{l}\text { *PGR (Plano de Gerenciamento de Risco) da } \\
\text { Eurochain: trata de diversos assuntos } \\
\text { relacionados a como operar, por exemplo, } \\
\text { perfil do motorista. }\end{array}$ & $\begin{array}{l}\text { Plano de } \\
\text { Gerenciament } \\
\text { o de riscos } \\
\text { apresentada. }\end{array}$ & Formal \\
\hline $\begin{array}{l}\text { Contexto } \\
\text { (aplicado a todas } \\
\text { as dimensões) }\end{array}$ & $\begin{array}{l}\text { *Planilha de orientação para o cliente emitir } \\
\text { Notas Fiscais no tempo correto para se } \\
\text { atingir os prazos de entrega demandados. (É } \\
\text { um documento da Eurochain para orientar a } \\
\text { Cialab sobre como e quando deve faturar as } \\
\text { suas vendas). }\end{array}$ & $\begin{array}{l}\text { Apresentado } \\
\text { outro controle } \\
\text { de prazo para } \\
\text { orientação do } \\
\text { cliente }\end{array}$ & Indiferente \\
\hline
\end{tabular}

Conclusão final: 5 itens demonstram que a Eurochain é fortemente Formalizada.

\subsubsection{Relacionamento Sul Deste Cargo - Eurochain}

\begin{tabular}{|c|c|c|c|}
\hline Critérios & $\begin{array}{c}\text { Trechos da Entrevista, Visitas e } \\
\text { Documentos }\end{array}$ & Análise & Resultado \\
\hline $\begin{array}{c}\text { Preços } \\
\text { definidos e } \\
\text { formalizados? }\end{array}$ & $\begin{array}{l}\text { "Existem tabelas de preço, com prazos } \\
\text { acordados, também temos o Plano de } \\
\text { Gerenciamento de Risco a ser seguido e } \\
\text { fazemos as reuniões." (Entrevistados } 1 \text { e } \\
\text { 2) }\end{array}$ & $\begin{array}{l}\text { As tabelas } \\
\text { preços não } \\
\text { foram } \\
\text { mostradas, o } \\
\text { entrevistado } \\
\text { não } \\
\text { mostrar. }\end{array}$ & $\begin{array}{l}\text { Desconsidera- } \\
\text { do }\end{array}$ \\
\hline $\begin{array}{c}\text { Níveis de } \\
\text { serviços estão } \\
\text { acordados e } \\
\text { formalizados? }\end{array}$ & $\begin{array}{l}\text { *Tabela de Prazos de entrega: tabela com } \\
\text { dias para entrega para cada região ou } \\
\text { cidade de destino (Entrevistados 1 e 2) } \\
\text { "Existem tabelas de preço, com prazos } \\
\text { acordados, também temos o Plano de } \\
\text { Gerenciamento de Risco a ser seguido e } \\
\text { fazemos as reuniões." (Entrevistados } 1 \text { e } \\
\text { 2) }\end{array}$ & $\begin{array}{l}\text { As tabelas de } \\
\text { prazos foram } \\
\text { evidenciadas }\end{array}$ & Formal \\
\hline
\end{tabular}




\begin{tabular}{|c|c|c|c|}
\hline $\begin{array}{l}\text { Acompanham } \\
\text { ento do nível } \\
\text { de serviço? }\end{array}$ & $\begin{array}{l}\text { "Temos um relatório com indicadores de } \\
\text { apuração semanal e também temos uma } \\
\text { reunião mensal com cada um deles." } \\
\text { (Entrevistados } 1 \text { e } \\
\text { "Ata com acompanhamento de ações } \\
\text { corretivas - lista de problemas que devem } \\
\text { ser resolvidos pelo transportador e os } \\
\text { prazos acordados para a implantação das } \\
\text { soluções, por exemplo, aumentar o } \\
\text { número de atendentes no call-center, ou } \\
\text { melhorar a performance no interior do } \\
\text { Espírito Santo." (Entrevistados } 1 \text { e } 2 \text { ) }\end{array}$ & $\begin{array}{l}\text { Ata de } \\
\text { acompanhamen } \\
\text { to de problemas } \\
\text { operacionais }\end{array}$ & Formal \\
\hline $\begin{array}{l}\text { Existe uma } \\
\text { prática de } \\
\text { reuniões } \\
\text { operacionais } \\
\text { padrão entre } \\
\text { fornecedor e } \\
\text { cliente? }\end{array}$ & 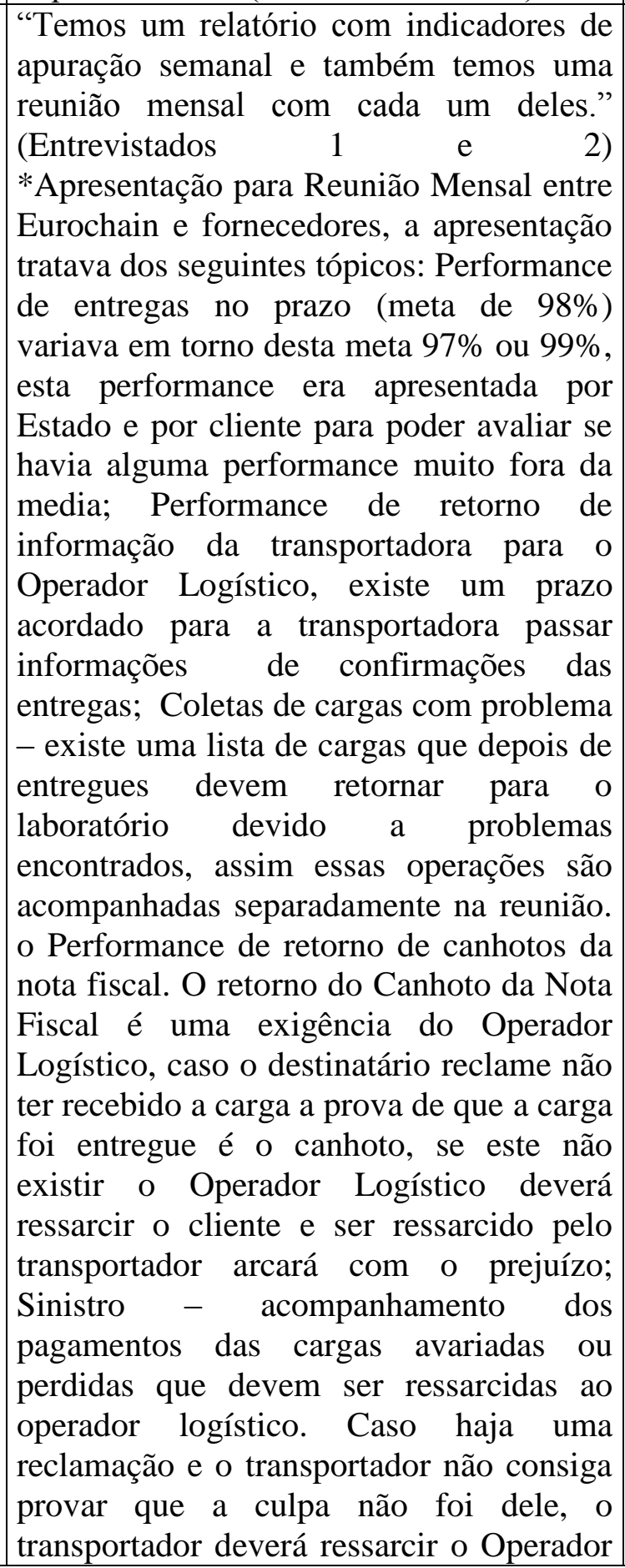 & $\begin{array}{lr}\text { As atas } & \text { de } \\
\text { reuniões } & \\
\text { deixam } & \text { bem } \\
\text { claras as } & \text { metas } \\
\text { para } & \text { os } \\
\text { fornecedores. }\end{array}$ & Formal \\
\hline
\end{tabular}




\begin{tabular}{|c|c|c|c|}
\hline & Logístico. (Entrevistados 1 e 2) & & \\
\hline $\begin{array}{c}\text { Existem } \\
\text { regras } \\
\text { padronizadas } \\
\text { com relação } \\
\text { aos riscos de } \\
\text { carga de alto } \\
\text { valor? }\end{array}$ & $\begin{array}{l}\text { “Existem tabelas de preço, com prazos } \\
\text { acordados, também temos o Plano de } \\
\text { Gerenciamento de Risco a ser seguido e } \\
\text { fazemos as reuniões."(Entrevistados } 1 \text { e 2) } \\
\text { *PGR (Plano de Gerenciamento de Risco) } \\
\text { da Eurochain: trata de diversos assuntos } \\
\text { relacionados a como operar, por exemplo, } \\
\text { perfil do motorista. }\end{array}$ & $\begin{array}{l}\text { A Eurochain } \\
\text { com certeza } \\
\text { possui as regras } \\
\text { de de } \\
\text { gerenciamento } \\
\text { de risco, porém } \\
\text { para checar esse } \\
\text { item do } \\
\text { fornecedor, } \\
\text { somente na } \\
\text { entrevista do } \\
\text { fornecedor. }\end{array}$ & $\begin{array}{c}\text { Desconsidera- } \\
\text { do }\end{array}$ \\
\hline $\begin{array}{c}\text { Contexto } \\
\text { (aplicado a } \\
\text { todas as } \\
\text { dimensões) }\end{array}$ & $\begin{array}{l}\text { "Não cumprimento do nível de serviço ou } \\
\text { então problemas na saúde financeiro do } \\
\text { transportador. Trabalhamos com alto valor } \\
\text { de mercadoria, o risco é alto e o } \\
\text { transportador precisa estar apto a lidar } \\
\text { com esse risco." (Entrevistados 1 e 2) } \\
\text { !Sim, temos uma constância no setor, não } \\
\text { mudamos muito de fornecedores. Temos } \\
\text { alguns já trabalhando conosco há mais de } \\
10 \text { anos, mas a média deve estar entre } 4 \text { a } \\
5 \text { anos conosco. É muito difícil lidar com } \\
\text { essas empresas, mas nos sabemos como } \\
\text { lidar com eles, são emocionais, assim, eles } \\
\text { precisam ter muita confiança na gente, } \\
\text { eles vão ver o histórico que tem conosco, } \\
\text { às vezes são pouco profissionais (creio } \\
\text { que ele estava falando sobre o mercado } \\
\text { em geral e não sobre as empresas do } \\
\text { farmacêutico), eles precisam pensar } \\
\text { "confio em você"." (Entrevistados 3) } \\
\text { "Checamos diversos critérios como: } \\
\text { Estrutura Física prédios e veículos, } \\
\text { também conferimos a saúde financeira da } \\
\text { empresa, pois eles carregam carga de alto } \\
\text { valor, a organização interna deles com } \\
\text { processos e procedimentos, capilaridade } \\
\text { ou o número de rotas, parceiros e opções } \\
\text { que eles possuem para chegar nos locais } \\
\text { mais distantes. Requerimentos legais } \\
\text { como licenças de funcionamento da } \\
\text { vigilância sanitária, bombeiros, exército, } \\
\text { gerenciamento de risco Anvisa e outros. } \\
\text { Conhece o setor que vai atuar e atende }\end{array}$ & $\begin{array}{l}\text { De acordo com } \\
\text { ao alto risco } \\
\text { deste } \\
\text { transporte, e um } \\
\text { processo } \\
\text { rigoroso de } \\
\text { seleção de } \\
\text { fornecedores, é } \\
\text { coerente que } \\
\text { haja } \\
\text { acompanhamen } \\
\text { to formal da } \\
\text { operação. }\end{array}$ & Formal \\
\hline
\end{tabular}




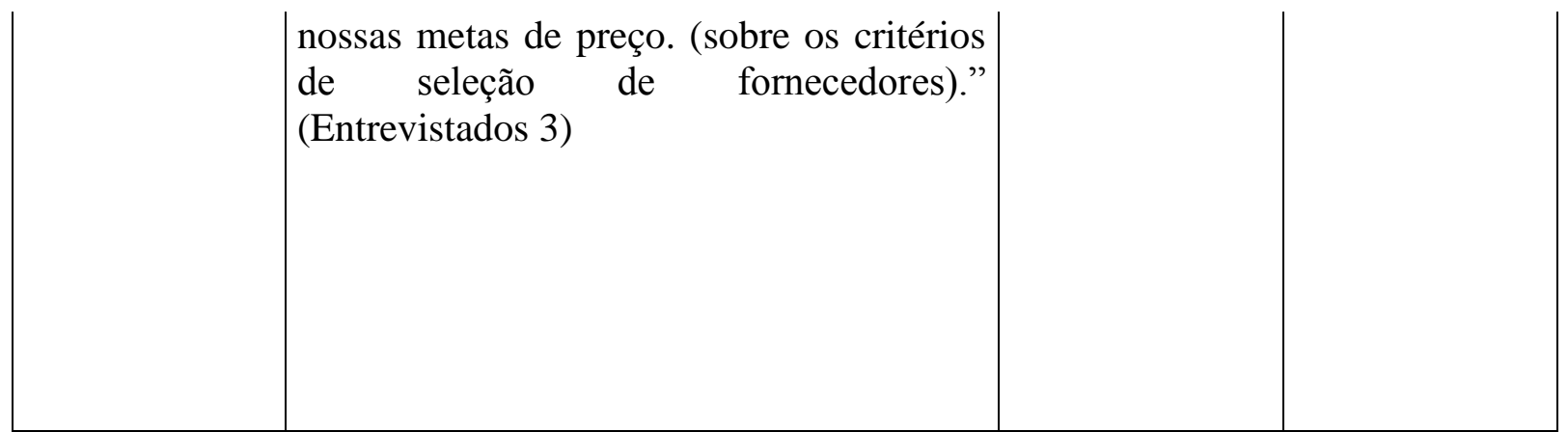

Conclusão final: 4 critérios são formalizados entre Eurochain e Sul Deste Cargo

\subsubsection{Relacionamento Eurochain - Air Cargo}

\begin{tabular}{|c|c|c|c|}
\hline Critérios & $\begin{array}{l}\text { Trechos da Entrevista, Visitas e } \\
\text { Documentos }\end{array}$ & Análise & $\begin{array}{c}\text { Resultad } \\
\text { o }\end{array}$ \\
\hline $\begin{array}{l}\text { Preços definidos } \\
\text { e formalizados? }\end{array}$ & $\begin{array}{l}\text { "Tabela de preço para modal aéreo: tabela } \\
\text { de preços que considera a variação de peso, } \\
\text { destino e valor de mercadoria." } \\
\text { (Entrevistados } \\
\text { "Existem tabelas de preço, com prazos } \\
\text { acordados, também temos o Plano de } \\
\text { Gerenciamento de Risco a ser seguido e } \\
\text { fazemos as reuniões." (Entrevistados } 1 \text { e 2) }\end{array}$ & $\begin{array}{l}\text { As tabelas de } \\
\text { preços do aéreo } \\
\text { foram } \\
\text { evidenciadas }\end{array}$ & Formal \\
\hline $\begin{array}{c}\text { Níveis de } \\
\text { serviços estão } \\
\text { acordados e } \\
\text { formalizados? }\end{array}$ & $\begin{array}{l}\text { *Tabela de Prazos de entrega: tabela com } \\
\text { dias para entrega para cada região ou cidade } \\
\text { de destino (Entrevistados } 1 \text { e } 2 \text { ) } \\
\text { "Existem tabelas de preço, com prazos } \\
\text { acordados, também temos o Plano de } \\
\text { Gerenciamento de Risco a ser seguido e } \\
\text { fazemos as reuniões." (Entrevistados } 1 \text { e 2) }\end{array}$ & $\begin{array}{l}\text { As tabelas de } \\
\text { prazos foram } \\
\text { evidenciadas }\end{array}$ & Formal \\
\hline $\begin{array}{l}\text { Acompanhamen } \\
\text { to do nível de } \\
\text { serviço? }\end{array}$ & $\begin{array}{l}\text { "Temos um relatório com indicadores de } \\
\text { apuração semanal e também temos uma } \\
\text { reunião mensal com cada um deles." } \\
\text { (Entrevistados } 1 \text { e } r \text { 2) } \\
\text { "Ata com acompanhamento de ações } \\
\text { corretivas - lista de problemas que devem } \\
\text { ser resolvidos pelo transportador e os prazos } \\
\text { acordados para a implantação das soluções, } \\
\text { por exemplo, aumentar o número de } \\
\text { atendentes no call-center, ou melhorar a } \\
\text { performance no interior do Espírito Santo." } \\
\text { (Entrevistados 1 e 2) }\end{array}$ & $\begin{array}{l}\text { Ata de } \\
\text { acompanhamento } \\
\text { de problemas } \\
\text { operacionais }\end{array}$ & Formal \\
\hline
\end{tabular}




\begin{tabular}{|c|c|c|c|}
\hline $\begin{array}{l}\text { Existe uma } \\
\text { prática de } \\
\text { reuniões } \\
\text { operacionais } \\
\text { padrão entre } \\
\text { fornecedor e } \\
\text { cliente? }\end{array}$ & $\begin{array}{l}\text { “Temos um relatório com indicadores de } \\
\text { apuração semanal e também temos uma } \\
\text { reunião mensal com cada um deles.” } \\
\text { (Entrevistados } 1 \text { e } \\
\text { *Apresentação para Reunião Mensal entre } \\
\text { Eurochain e fornecedores, a apresentação } \\
\text { tratava dos seguintes tópicos: Performance } \\
\text { de entregas no prazo (meta de 98\%) variava } \\
\text { em torno desta meta 97\% ou 99\%, esta } \\
\text { performance era apresentada por Estado e } \\
\text { por cliente para poder avaliar se havia } \\
\text { alguma performance muito fora da media; } \\
\text { Performance de retorno de informação da } \\
\text { transportadora para o Operador Logístico, } \\
\text { existe um prazo acordado para a } \\
\text { transportadora passar informações de } \\
\text { confirmações das entregas; Coletas de } \\
\text { cargas com problema - existe uma lista de } \\
\text { cargas que depois de entregues devem } \\
\text { retornar para o laboratório devido a } \\
\text { problemas encontrados, assim essas } \\
\text { operações são acompanhadas separadamente } \\
\text { na reunião; Performance de retorno de } \\
\text { canhotos da nota fiscal. O retorno do } \\
\text { Canhoto da Nota Fiscal é uma exigência do } \\
\text { Operador Logístico, caso o destinatário } \\
\text { reclame não ter recebido a carga a prova de } \\
\text { que a carga foi entregue é o canhoto, se este } \\
\text { não existir o Operador Logístico deverá } \\
\text { ressarcir o cliente e ser ressarcido pelo } \\
\text { transportador arcará com o prejuízo; } \\
\text { Sinistro - acompanhamento dos pagamentos } \\
\text { das cargas avariadas ou perdidas que devem } \\
\text { ser ressarcidas ao operador logístico. Caso } \\
\text { haja uma reclamação e o transportador não } \\
\text { consiga provar que a culpa não foi dele, o } \\
\text { transportador deverá ressarcir o Operador } \\
\text { Logístico. (Entrevistados } 1 \text { e } 2 \text { ) }\end{array}$ & $\begin{array}{llr}\text { As } & \text { atas } & \text { de } \\
\text { reuniões deixam } & \\
\text { bem claro } & \text { as } \\
\text { metas para } & \text { os } \\
\text { fornecedores. } & \end{array}$ & Formal \\
\hline $\begin{array}{l}\text { Existem regras } \\
\text { padronizadas } \\
\text { com relação aos } \\
\text { riscos de carga } \\
\text { de alto valor? }\end{array}$ & $\begin{array}{l}\text { "Existem tabelas de preço, com prazos } \\
\text { acordados, também temos o Plano de } \\
\text { Gerenciamento de Risco a ser seguido e } \\
\text { fazemos as reuniões." (Entrevistados 1 e 2) } \\
\text { *PGR (Plano de Gerenciamento de Risco) } \\
\text { da Eurochain: trata de diversos assuntos } \\
\text { relacionados a como operar, por exemplo, } \\
\text { perfil do motorista. }\end{array}$ & $\begin{array}{l}\text { A Eurochain com } \\
\text { certeza possui as } \\
\text { regras de de } \\
\text { gerenciamento de } \\
\text { risco, porém para } \\
\text { checar esse item } \\
\text { do fornecedor, } \\
\text { somente ra } \\
\text { entrevista do } \\
\text { fornecedor. }\end{array}$ & $\begin{array}{l}\text { Descon- } \\
\text { siderado }\end{array}$ \\
\hline $\begin{array}{l}\text { Contexto } \\
\text { (aplicado a } \\
\text { todas as }\end{array}$ & $\begin{array}{l}\text { "Não cumprimento do nível de serviço ou } \\
\text { então problemas na saúde financeira do } \\
\text { transportador. Trabalhamos com alto valor }\end{array}$ & $\begin{array}{lrr}\text { De } & \text { acordo } & \text { com } \\
\text { ao } & \text { alto } & \text { risco } \\
\text { deste } & \text { transporte, }\end{array}$ & Formal \\
\hline
\end{tabular}




\begin{tabular}{|c|c|c|}
\hline dimensões) & $\begin{array}{l}\text { de mercadoria, o risco é alto e o } \\
\text { transportador precisa estar apto a lidar com } \\
\text { esse risco."(Entrevistados 1 e 2) } \\
\text { "Sim, temos uma constância no setor, não } \\
\text { mudamos muito de fornecedores. Temos } \\
\text { alguns já trabalhando conosco há mais de } 10 \\
\text { anos, mas a média deve estar entre } 4 \text { a } 5 \\
\text { anos conosco. É muito difícil lidar com } \\
\text { essas empresas, mas nos sabemos como lidar } \\
\text { com eles, eles são emocionais, assim, eles } \\
\text { precisam ter muita confiança na gente, eles } \\
\text { vão ver o histórico que tem conosco, às } \\
\text { vezes são pouco profissionais (creio que ele } \\
\text { estava falando sobre o mercado em geral e } \\
\text { não sobre as empresas do farmacêutico), eles } \\
\text { precisam pensar confio em } \\
\text { você".(Entrevistados } \\
\text { "Checamos diversos critérios como: } \\
\text { Estrutura Física prédios e veículos, também } \\
\text { conferimos a saúde financeira da empresa, } \\
\text { pois eles carregam carga de alto valor, a } \\
\text { organização interna deles com processos e } \\
\text { procedimentos, capilaridade ou o número de } \\
\text { rotas, parceiros e opções que eles possuem } \\
\text { para chegar nos locais mais distantes. } \\
\text { Requerimentos legais como licenças de } \\
\text { funcionamento da vigilância sanitária, } \\
\text { bombeiros, exército, gerenciamento de risco } \\
\text { Anvisa e outros. Conhece o setor que vai } \\
\text { atuar e atende nossas metas de preço. (sobre } \\
\text { os critérios de seleção de fornecedores)." } \\
\text { (Entrevistados 3) }\end{array}$ & 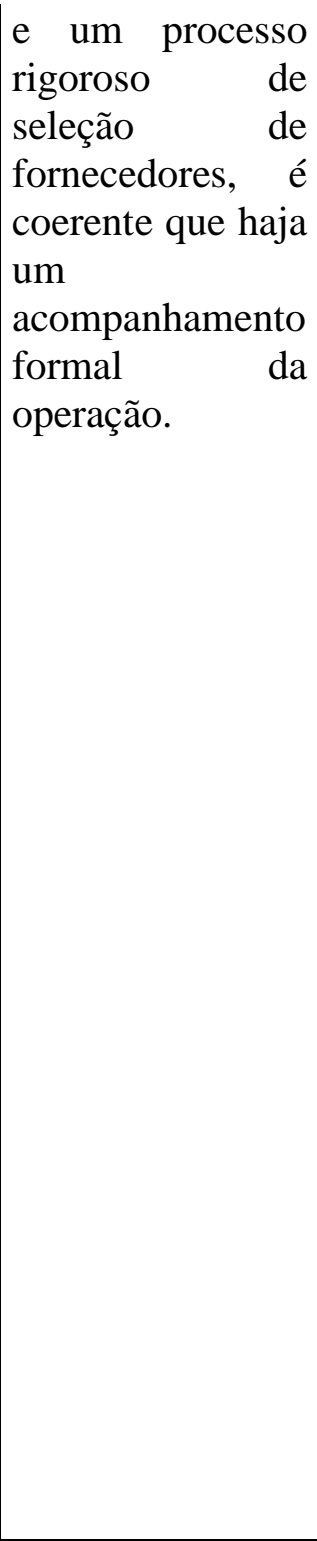 \\
\hline
\end{tabular}

Conclusão final: 5 critérios são formalizados entre Eurochain e Air Cargo 


\subsubsection{Integração}

\subsubsection{Relacionamento Cialab - Eurochain}

\begin{tabular}{|c|c|c|c|}
\hline Critérios & $\begin{array}{c}\text { Trechos da Entrevista, Visitas e } \\
\text { Documentos }\end{array}$ & Análise & Resultado \\
\hline $\begin{array}{l}\text { Iniciativas em } \\
\text { conjunto que } \\
\text { proporcionem } \\
\text { benefícios } \\
\text { para ambas as } \\
\text { empresas }\end{array}$ & $\begin{array}{l}\text { "Tivemos os } 13 \text { primeiros anos tranquilos } \\
\text { com ótimo nível de serviço e boa } \\
\text { lucratividade. Mas o cliente tem se tornado } \\
\text { cada vez mais exigente, houve alterações de } \\
\text { contrato e níveis de serviço. Nossa relação } \\
\text { com o cliente ficou mais próxima, o primeiro } \\
\text { responsável pela operação no cliente montou } \\
\text { uma sala no nosso prédio junto com uma } \\
\text { pessoa do exterior também (em situação de } \\
\text { risco)". (Entrevistados } 1 \text { e } \\
\text { "Estamos muito satisfeitos, é uma operação } \\
\text { de benchmarking, uma conta boa. Nesta } \\
\text { operação desenvolvemos inovações, existe } \\
\text { uma troca para os dois lados." (Entrevistados } \\
1 \text { e } \\
\text { "Existem esforços isolados, mas nada que } \\
\text { atinja toda a cadeia. A cadeia não conversa, } \\
\text { não existe um dialogo geral entre Indústria, } \\
\text { Opperador logístico e destinatários." } \\
\text { (Entrevistados 3) }\end{array}$ & $\begin{array}{lr}\text { Embora } & \text { os } \\
\text { entrevistados não } & \\
\text { tenham citado } & \text { iniciativas claras, } \\
\text { disseram que } & \text { que } \\
\text { geram pequenas } \\
\text { melhorias para } \\
\text { ambos os lados e } \\
\text { se cria um } \\
\text { benchmarking, o } \\
\text { que ré } \\
\text { identificado na } \\
\text { literatura como } \\
\text { um grau de } \\
\text { colaboração. }\end{array}$ & Integração \\
\hline $\begin{array}{c}\text { Contexto } \\
\text { (aplicado a } \\
\text { todas as } \\
\text { dimensões) }\end{array}$ & $\begin{array}{l}\text { "Um exemplo de problema que não está na } \\
\text { nossa responsabilidade, o destinatário não } \\
\text { recebe, pois diz que não existe pedido para } \\
\text { aquela mercadoria, o cliente se não estiver } \\
\text { próximo irá entender que essa entrega é um } \\
\text { atraso nosso, porém é falha de comunicação } \\
\text { da Indústria com o seu cliente. (Entrevistados } \\
1 \text { e } \\
\text { "O desenvolvimento do serviço tem que ser } \\
\text { feito a } 4 \text { mãos, não adianta ele terceirizar e } \\
\text { largar, eu não arrumo tudo sozinho. Tem } \\
\text { problema que é do destinatário, não é erro } \\
\text { nosso. Por exemplo, às vezes o sistema do } \\
\text { destinatário não reconhece a nota fiscal." } \\
\text { (Entrevistados } \\
\text { "Quando nós fazemos alguma alteração } \\
\text { damos treinamento para os fornecedores, mas } \\
\text { o cliente já assume que conseguiremos } \\
\text { (cliente não se preocupa em treinar)." } \\
\text { (Entrevistados 3) }\end{array}$ & 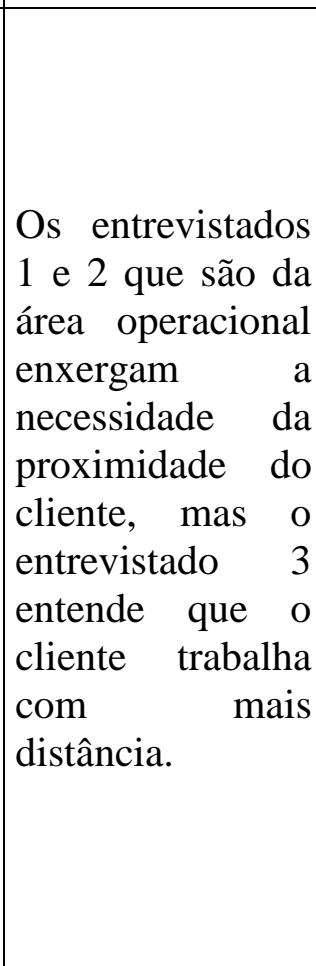 & Indiferente \\
\hline
\end{tabular}




\begin{tabular}{|c|c|c|c|}
\hline $\begin{array}{l}\text { *Comunica- } \\
\text { ção }\end{array}$ & $\begin{array}{l}\text { "Às vezes aparecem demandas que não } \\
\text { temos como cumprir, nesse caso após } \\
\text { justificarmos bem o cliente compreende os } \\
\text { riscos e a inviabilidade, ou seja, temos um } \\
\text { diálogo aberto.(Entrevistados 1 e 2) } \\
\text { "Quando os principais clientes do laboratório } \\
\text { fazem alguma alteração, muitas vezes não } \\
\text { sabemos de nada, ficamos sabendo só que a } \\
\text { carga não foi recebida ou sabemos pela } \\
\text { reclamação da Cialab." (Entrevistados 3) } \\
\text { "Existem esforços isolados, mas nada que } \\
\text { atinja toda a cadeia.A cadeia não conversa, } \\
\text { não existe um dialogo geral entre Indústria, } \\
\text { Operador logístico e destinatários." } \\
\text { (Entrevistados } \\
\text { "Eles até abrem para discutir, mas } \\
\text { geralmente assumem que iremos conseguir e } \\
\text { pronto, eles pensam "vocês são a Eurochain, } \\
\text { vocês vão dar um jeito e conseguir", é isso } \\
\text { que eles assumem." }\end{array}$ & 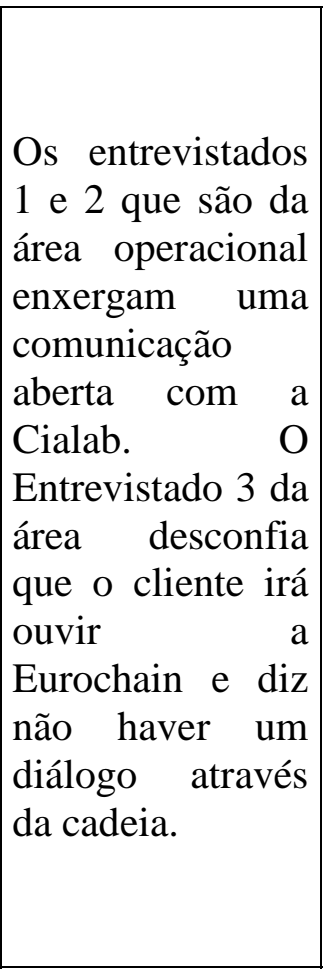 & Indiferente \\
\hline *Confiança & $\begin{array}{l}\text { "A indústria é quem possui poder para ligar } \\
\text { as partes e fazer comunicação, mas } \\
\text { atualmente só passamos informação. Até } \\
\text { temos abertura para conversar, mas se } \\
\text { seremos ouvidos é outra história." } \\
\text { (Entrevistados 3) }\end{array}$ & $\begin{array}{lrr}\text { O } & \text { entrevistado } & 3 \\
\text { não tem } & \text { plena } \\
\text { confiança } & \text { se } \\
\text { serão } & \text { ouvidos } \\
\text { pela indústria. }\end{array}$ & $\begin{array}{c}\text { Sem } \\
\text { Integração }\end{array}$ \\
\hline $\begin{array}{c}* \text { Tempo de } \\
\text { relacionamen- } \\
\text { to }\end{array}$ & $\begin{array}{l}\text { "Temos esta conta há } 15 \text { anos." } \\
\text { (Entrevistados } \\
\text { "Que eu me lembro, temos esta parceria há } \\
\text { mais de } 14 \text { anos." (Entrevistados } 3 \text { ) }\end{array}$ & 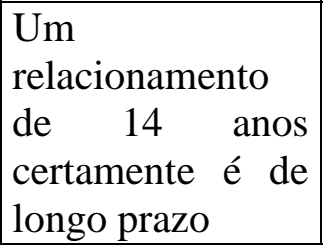 & Integração \\
\hline
\end{tabular}

Conclusão final: 2 critério demonstra leve integração entre Cialab e a Eurochain, as entrevistas mostram uma divergência de entendimento entre o time de compra e o time operacional.

\subsubsection{Relacionamento Sul Deste Cargo - Eurochain}

\begin{tabular}{|c|c|c|c|}
\hline Critérios & Trechos da Entrevista, Visitas e Documentos & Análise & Resultado \\
\hline $\begin{array}{c}\text { Iniciativas em } \\
\text { conjunto que } \\
\text { proporcionem } \\
\text { benefícios } \\
\text { para ambas as } \\
\text { empresas }\end{array}$ & $\begin{array}{l}\text { "Existem esforços isolados, mas nada que atinja } \\
\text { toda a cadeia. A cadeia não conversa, não existe } \\
\text { um dialogo geral entre Indústria, Operador } \\
\text { logístico e destinatários." (Entrevistados 3) }\end{array}$ & $\begin{array}{l}\text { Nenhuma } \\
\text { iniciativa de } \\
\text { integração } \\
\text { identificada }\end{array}$ & $\begin{array}{c}\text { Sem } \\
\text { Integração }\end{array}$ \\
\hline
\end{tabular}




\begin{tabular}{|c|c|c|c|}
\hline $\begin{array}{l}\text { Contexto } \\
\text { (aplicado a } \\
\text { todas as } \\
\text { dimensões) }\end{array}$ & $\begin{array}{l}\text { "Nível de serviço ou Custo. Às vezes o } \\
\text { transportador pede reajuste de } 30 \% \text { ou ameaça } \\
\text { de ir embora. Quando o problema é nível de } \\
\text { serviço a última opção é cortar o fornecedor, } \\
\text { tentamos fortemente desenvolvê-lo. É muito } \\
\text { complexo trocar de fornecedores, pois sempre } \\
\text { temos um grande trabalho de transferência de } \\
\text { conhecimento para o fornecedor, atualmente o } \\
\text { mercado está escasso de bons fornecedores, não } \\
\text { se encontra fornecedores bem preparados." } \\
\text { (Entrevistados 3) }\end{array}$ & $\begin{array}{l}\text { Existe um } \\
\text { pensamento } \\
\text { de } \\
\text { desenvolver } \\
\text { fornecedores, } \\
\text { transferência } \\
\text { de know-how. }\end{array}$ & Integração \\
\hline $\begin{array}{c}\text { *Comunica- } \\
\text { ção }\end{array}$ & $\begin{array}{l}\text { "Existem esforços isolados, mas nada que atinja } \\
\text { toda a cadeia. A cadeia não conversa, não existe } \\
\text { um dialogo geral entre Indústria, Operador } \\
\text { logístico e destinatários." (Entrevistados 3) }\end{array}$ & $\begin{array}{l}\text { Nenhuma } \\
\text { iniciativa de } \\
\text { integração } \\
\text { identificada }\end{array}$ & $\begin{array}{c}\text { Sem } \\
\text { Integração }\end{array}$ \\
\hline *Confiança & $\begin{array}{l}\text { "Sim, temos uma constância no setor, não } \\
\text { mudamos muito de fornecedores. Temos alguns } \\
\text { já trabalhando conosco há mais de } 10 \text { anos, mas } \\
\text { a média deve estar entre } 4 \text { a } 5 \text { anos conosco. É } \\
\text { muito difícil lidar com essas empresas, mas nos } \\
\text { sabemos como lidar com eles, são emocionais, } \\
\text { assim, eles precisam ter muita confiança na } \\
\text { gente, eles vão ver o histórico que tem conosco, } \\
\text { às vezes são pouco profissionais (creio que ele } \\
\text { estava falando sobre o mercado em geral e não } \\
\text { sobre as empresas do farmacêutico), eles } \\
\text { precisam pensar confio e em } \\
\text { você".(Entrevistados } 3 \text { ) }\end{array}$ & $\begin{array}{l}\text { O } \\
\text { entrevistado } 3 \\
\text { entende a } \\
\text { necessidade } \\
\text { da confiança } \\
\text { no } \\
\text { relacionament } \\
\text { o, entretanto } \\
\text { não existem } \\
\text { evidências de } \\
\text { confiança na } \\
\text { relação. }\end{array}$ & $\begin{array}{c}\text { Sem } \\
\text { Integração }\end{array}$ \\
\hline $\begin{array}{l}* \text { Tempo de } \\
\text { relacionamen- } \\
\text { to }\end{array}$ & $\begin{array}{l}\text { "Creio que em média os transportadores devem } \\
\text { estar trabalhando conosco há } 6 \text { anos, temos } \\
\text { alguns com } 15 \text { anos." (Entrevistados } 1 \text { e } 2 \text { ) } \\
\text { "No setor farmacêutico temos em média } 4 \text { a } 5 \\
\text { anos." (Entrevistados 3) }\end{array}$ & $\begin{array}{l}\text { Os } \\
\text { entrevistados } \\
\text { concordam } \\
\text { que os } \\
\text { transportadore } \\
\text { s possuem um } \\
\text { tempo médio } \\
\text { de } \\
\text { relacionament } \\
\text { o } 5 \text { anos. }\end{array}$ & Indiferente \\
\hline
\end{tabular}

Conclusão final: 3 critérios demonstram fortemente a falta de integração entre Sul Deste Cargo e a Eurochain. 


\subsubsection{Relacionamento Eurochain - Air Cargo}

\begin{tabular}{|c|c|c|c|}
\hline Critérios & $\begin{array}{c}\text { Trechos da Entrevista, Visitas e } \\
\text { Documentos }\end{array}$ & Análise & Resultado \\
\hline $\begin{array}{l}\text { Iniciativas em } \\
\text { conjunto que } \\
\text { proporcionem } \\
\text { benefícios } \\
\text { para ambas as } \\
\text { empresas }\end{array}$ & $\begin{array}{l}\text { "Existem esforços isolados, mas nada que } \\
\text { atinja toda a cadeia. A cadeia não conversa, } \\
\text { não existe um dialogo geral entre Indústria, } \\
\text { Operador logístico e destinatários." } \\
\text { (Entrevistados 3) }\end{array}$ & $\begin{array}{l}\text { Nenhuma } \\
\text { iniciativa de } \\
\text { integração } \\
\text { identificada }\end{array}$ & $\begin{array}{c}\text { Sem } \\
\text { Integração }\end{array}$ \\
\hline $\begin{array}{c}\text { Contexto } \\
\text { (aplicado a } \\
\text { todas as } \\
\text { dimensões) }\end{array}$ & $\begin{array}{l}\text { "Nível de serviço ou Custo. Às vezes o } \\
\text { transportador pede reajuste de } 30 \% \text { ou ameaça } \\
\text { de ir embora. Quando o problema é nível de } \\
\text { serviço a última opção é cortar o fornecedor, } \\
\text { tentamos fortemente desenvolvê-lo. É muito } \\
\text { complexo trocar de fornecedores, pois sempre } \\
\text { temos um grande trabalho de transferência de } \\
\text { conhecimento para o fornecedor, atualmente o } \\
\text { mercado está escasso de bons fornecedores, } \\
\text { não se encontra fornecedores bem } \\
\text { preparados." (Entrevistados } 3 \text { ) }\end{array}$ & $\begin{array}{l}\text { Existe um } \\
\text { pensamento de } \\
\text { desenvolver } \\
\text { fornecedores, } \\
\text { transferência de } \\
\text { know-how. }\end{array}$ & Integração \\
\hline $\begin{array}{l}\text { *Comunica- } \\
\text { ção }\end{array}$ & $\begin{array}{l}\text { "Existem esforços isolados, mas nada que } \\
\text { atinja toda a cadeia. A cadeia não conversa, } \\
\text { não existe um dialogo geral entre Indústria, } \\
\text { Operador logístico e destinatários." } \\
\text { (Entrevistados 3) }\end{array}$ & $\begin{array}{l}\text { Nenhuma } \\
\text { iniciativa de } \\
\text { integração } \\
\text { identificada }\end{array}$ & $\begin{array}{c}\text { Sem } \\
\text { Integração }\end{array}$ \\
\hline *Cor & $\begin{array}{l}\text { "Sim, temos uma constância no setor, não } \\
\text { mudamos muito de fornecedores. Temos } \\
\text { alguns já trabalhando conosco há mais de } 10 \\
\text { anos, mas a média deve estar entre } 4 \text { a } 5 \text { anos } \\
\text { conosco. É muito difícil lidar com essas } \\
\text { empresas, mas nos sabemos como lidar com } \\
\text { eles, são emocionais, assim, eles precisam ter } \\
\text { muita confiança na gente, eles vão ver o } \\
\text { histórico que tem conosco, às vezes são pouco } \\
\text { profissionais (creio que ele estava falando } \\
\text { sobre o mercado em geral e não sobre as } \\
\text { empresas do farmacêutico), eles precisam } \\
\text { pensar "confio em você"." (Entrevistados } 3 \text { ) }\end{array}$ & $\begin{array}{lr}\text { O } & \text { entrevistado } \\
3 & \text { entende } \\
\text { necessidade } & \text { da } \\
\text { confiança no } & \text { no } \\
\text { relacionamento, } & \text { entretanto não } \\
\text { existem } & \\
\text { evidências } & \text { de } \\
\text { confiança } & \text { na } \\
\text { relação. } & \end{array}$ & $\begin{array}{c}\text { Sem } \\
\text { Integração }\end{array}$ \\
\hline $\begin{array}{l}* \text { Tempo de } \\
\text { relacionamen- } \\
\text { to }\end{array}$ & $\begin{array}{l}\text { "Creio que em média os transportadores } \\
\text { devem estar trabalhando conosco há } 6 \text { anos, } \\
\text { temos alguns com } 15 \text { anos." (Entrevistados } 1 \text { e } \\
\text { 2) } \\
\text { "No setor farmacêutico temos em média } 4 \text { a } 5 \\
\text { anos." (Entrevistados 3) }\end{array}$ & $\begin{array}{l}\text { Os } \\
\text { entrevistados } \\
\text { concordam que } \\
\text { os } \\
\text { transportadores } \\
\text { possuem um } \\
\text { tempo médio de } \\
\text { relacionamento } \\
5 \text { anos. } \\
\end{array}$ & Indiferente \\
\hline
\end{tabular}


Conclusão final: 3 critérios demonstram fortemente a falta de integração entre Air Cargo e a Eurochain.

\subsection{Análise intra-empresa Cialab}

\subsubsection{Centralização}

\subsubsection{Relacionamento Cialab - Eurochain}

\begin{tabular}{|c|c|c|c|}
\hline Critérios & $\begin{array}{c}\text { Trechos da Entrevista, Visitas e } \\
\text { Documentos }\end{array}$ & Análise & Resultado \\
\hline Negociações & $\begin{array}{l}\text { "Existe sim (multa e bônus sobre a } \\
\text { Eurochain), fazemos o cálculo trimestral da } \\
\text { performance, temos algo que impacta em } 1 \% \\
\text { do valor do pagamento. A cada } 2 \text { meses com } \\
\text { performance acima da média é compensado } 1 \\
\text { mês abaixo, com isso nossa intenção é o foco } \\
\text { na performance operacional e não em } \\
\text { melhorar nossos custos de logística." } \\
\text { "Temos uma negociação equilibrada, } \\
\text { negociamos todas as alterações (novas } \\
\text { mudanças)." } \\
\text { "Não pelos nossos clientes, só de nós para os } \\
\text { nossos fornecedores. O único cliente que nos } \\
\text { cobra multa é o governo." }\end{array}$ & $\begin{array}{lrr}\text { O } & \text { mecanismo de } \\
\text { bônus e } & \text { multas } \\
\text { descrito } & \text { é } & \text { uma } \\
\text { mecanismo } & \text { com } \\
\text { foco } & \text { na } \\
\text { performance e não } \\
\text { em gerar ganhos } \\
\text { financeiros. }\end{array}$ & Equilíbrio \\
\hline Autonomia & $\begin{array}{l}\text { Análise do Questionário Autonomia para } \\
\text { Execução do Serviço: De acordo com a } \\
\text { visão da Cialab, eles fazem um controle } \\
\text { rígido das questões de segurança da carga, } \\
\text { outros temas que possuem interface direta } \\
\text { com a Cialab, como reuniões também } \\
\text { recebem influência da própria Cialab. Porém } \\
\text { outros temas operacionais não possuem } \\
\text { interferência direta, sendo que os } \\
\text { fornecedores têm autonomia para trabalhar } \\
\text { dentro das regras legais para cargas de } \\
\text { medicamento. Tanto a Eurochain quanto seus } \\
\text { fornecedores tem liberdade para definirem } \\
\text { em torno de } 5 \text { elementos, como contratação } \\
\text { de transportadores, definição de equipe, } \\
\text { veículos outros. } \\
\text { Quando temos alguma entrega que necessita } \\
\text { voltar por algum problema, ela só pode voltar } \\
\text { se a área Comercial da Cialab der } \\
\text { autorização. } \\
\text { A força da área comercial da Cialab } \\
\text { internamente é muito forte, se temos um } \\
\text { pequeno problema na operação, às vezes um } \\
\text { problema comum, a alta gestão (alta } \\
\text { hierarquia dos executivos) do continente } \\
\text { americano pode ser acionada pela área }\end{array}$ & 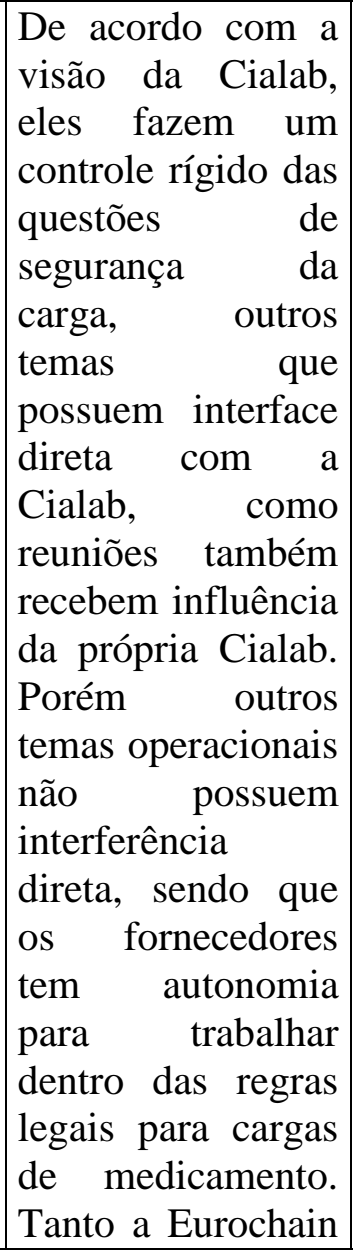 & Equilíbrio \\
\hline
\end{tabular}




\begin{tabular}{|c|c|c|c|}
\hline & $\begin{array}{l}\text { comercial. Assim, precisamos ter as } \\
\text { justificações corretas e claras para gerar o } \\
\text { entendimento necessário de todos os } \\
\text { envolvidos. }\end{array}$ & \begin{tabular}{|lr} 
quanto & seus \\
fornecedores & tem \\
liberdade & para \\
definirem & em \\
torno de & 5 \\
elementos, & como \\
contratação & de \\
transportadores, \\
definição & de \\
equipe, veículos e \\
outros.
\end{tabular} & \\
\hline $\begin{array}{l}\text { Contexto } \\
\text { (aplicado a } \\
\text { todas as } \\
\text { dimensões) }\end{array}$ & $\begin{array}{l}\text { "Temos contratados } 2 \text { operadores logísticos: } \\
\text { a Eurochain e outra empresa. Mas a } \\
\text { Eurochain é responsável por todo o nosso } \\
\text { transporte de produtos acabados que são } \\
\text { vendidos. O outro operador só cuida de } \\
\text { medicamentos de amostra grátis que é um } \\
\text { volume muito menor, é importante, mas não } \\
\text { é como as nossas vendas. } \\
2 \text { fornecedores diretos o principal deles é a } \\
\text { Eurochain." "A Eurochain pelo grande volume dela" (é o } \\
\text { "Arnecedor mais importante) } \\
\text { "Nossos contratos seguem um padrão, que } \\
\text { sempre terão duração de } 3 \text { anos, e depois } \\
\text { vamos renovando a cada } 3 \text { anos." } \\
\text { "Só mantivemos } 2 \text { operadores porque } \\
\text { sabemos que quando o volume dos produtos } \\
\text { comuns aumenta muito a tendência é que a } \\
\text { atenção dada amostras grátis diminua, assim } \\
\text { para termos atenção maior a essa carga } \\
\text { demos esta gestão para um operador } \\
\text { diferente." }\end{array}$ & $\begin{array}{lr}\text { A Cialab possui } \\
\text { somente } \\
\text { fornecedores, } \\
\text { porém a Eurochain } \\
\text { é a principal, só } \\
\text { mantiveram r o } \\
\text { segundo para não } \\
\text { haver risco das } \\
\text { cargas de amostra } \\
\text { grátis ficarem sem } \\
\text { atenção r da } \\
\text { Eurochain. }\end{array}$ & Indiferente \\
\hline $\begin{array}{l}\text { *Importân- } \\
\text { cia de uma } \\
\text { empresa } \\
\text { para a outra }\end{array}$ & $\begin{array}{l}\text { "Esta linha de produtos que está com a } \\
\text { Eurochain é o principal, é tudo que é vendido } \\
\text { no } \\
\text { "Para a Eurochain temos mais de } 3000 \\
\text { posições pallets no armazém. Para o nosso } \\
\text { outro operador logístico temos } 300 \text { posições } \\
\text { pallets, ou seja, nossa grande operação é com } \\
\text { a "Qurochain." } \\
\text { "Quebra de gôndola é um problema muito } \\
\text { sério para os nossos produtos que competem } \\
\text { com genérico, pois caso falte o produto na } \\
\text { farmácia ele irá comprar outro, assim } \\
\text { perdemos espaço no mercado. Porém em }\end{array}$ & 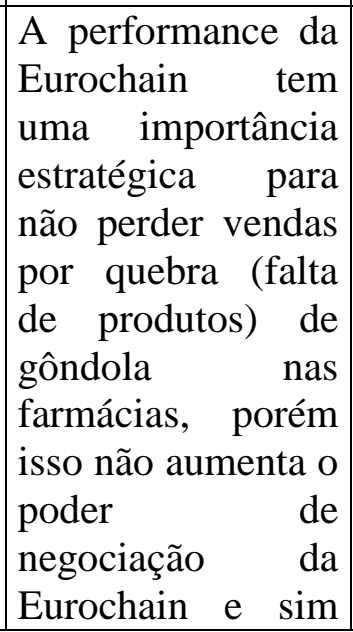 & Indiferente \\
\hline
\end{tabular}




\begin{tabular}{|c|c|c|c|}
\hline & $\begin{array}{l}\text { produtos que a patente ainda está vigente } \\
\text { temos maior poder de negociação. O } \\
\text { mercado no qual temos maior concorrência } \\
\text { são nos produtos sem receita, com complexo } \\
\text { vitamínico, os genéricos e os sem patente. } \\
\text { Considerando esse cenário, a logística de } \\
\text { distribuição se torna estratégica para a } \\
\text { empresa para ganhar e manter a participação } \\
\text { no mercado." }\end{array}$ & $\begin{array}{l}\text { sua } \\
\text { responsabilidade. }\end{array}$ & \\
\hline $\begin{array}{l}\text { *Participa- } \\
\text { ção no } \\
\text { faturamento }\end{array}$ & $\begin{array}{l}\text { "Em compras de serviços logísticos gastamos } \\
\text { em torno de R\$ } 40 \text { milhões por ano. } \\
100 \% \text { dos produtos vendidos, (não amostra } \\
\text { grátis), são distribuídos pela Eurochain." }\end{array}$ & $\begin{array}{lr}100 \% & \text { dos } \\
\text { produtos } & \text { vendidos, } \\
\text { (não } & \text { amostra } \\
\text { grátis), } & \text { são } \\
\text { distribuídos pela } \\
\text { Eurochain, isso } \\
\text { concentra poder na } \\
\text { mão da Eurochain, } \\
\text { pois em caso de } \\
\text { desacordo a Cialab } \\
\text { não consegue } \\
\text { facilmente trocar } \\
\text { de fornecedor. }\end{array}$ & $\begin{array}{l}\text { Eurochain } \\
\text { concentra } \\
\text { mais } \\
\text { poder }\end{array}$ \\
\hline
\end{tabular}

Conclusão Final: 1 iten elege a Eurochain, assim a Eurochain concentra levemente o poder na relação.

\subsubsection{Formalização}

\subsubsection{Cialab}

\begin{tabular}{|c|c|c|c|}
\hline Critérios & $\begin{array}{l}\text { Trechos da Entrevista, Visitas e } \\
\text { Documentos }\end{array}$ & Análise & $\begin{array}{c}\text { Resultad } \\
\text { o }\end{array}$ \\
\hline $\begin{array}{l}\text { Preços } \\
\text { e form }\end{array}$ & *Tabela de preços - é um anexo do contrato & $\begin{array}{l}\text { Tabela de preços } \\
\text { evidenciada }\end{array}$ & Formal \\
\hline $\begin{array}{c}\text { Níveis de } \\
\text { serviços estão } \\
\text { acordados e } \\
\text { formalizados? }\end{array}$ & $\begin{array}{l}\text { *Contrato com fornecedores }-150 \text { páginas } \\
\text { de contrato sobre produtos transportados, } \\
\text { serviços comprados, níveis de serviço, } \\
\text { atendimento, acompanhamento, reuniões e } \\
\text { etc. } \\
\text { SLA - Acordo de Nível de Serviço - estava } \\
\text { no contrato, meta de } 98 \%\end{array}$ & $\begin{array}{l}\text { SLA - Acordo de } \\
\text { Nível de Serviço } \\
-\quad \text { estava no } \\
\text { contrato, meta de } \\
98 \% \text { - } \\
\text { evidenciado }\end{array}$ & Formal \\
\hline $\begin{array}{l}\text { Acompanhamen } \\
\text { to do nível de } \\
\text { serviço? }\end{array}$ & $\begin{array}{l}\text { "Temos relatórios semanais e diários. } \\
\text { Reuniões operacionais mensais } \\
\text { trimestrais." } \\
\text { * Relatório de acompanhamento de } \\
\text { performance }- \text { foi mostrado o o } \\
\text { acompanhamento de performance por mês, } \\
\text { mostrando todas as possíveis ocorrências } \\
\text { com responsáveis apontados como Cialab } \\
\text { comercial, Cialab operação, clientes Cialab, }\end{array}$ & $\begin{array}{l}\text { Pelo menos } 3 \\
\text { relatórios } \\
\text { diferentes foram } \\
\text { apresentados } \\
\text { sobre } \\
\text { acompanhamento } \\
\text { de performance } \\
\text { da operação. }\end{array}$ & Formal \\
\hline
\end{tabular}




\begin{tabular}{|c|c|c|c|}
\hline & $\begin{array}{l}\text { Eurochain, Governo e } r \text { outros. } \\
\text { * Relatório de acompanhamento dos TOP } 13 \\
-13 \text { principais clientes por tamanho de } \\
\text { faturamento, representam } 75 \% \text { do } \\
\text { faturamento Cialab. } \\
\text { *Relatório Cialab de acompanhamento - } \\
\text { quantidade de nfs, prazos de entrega, } \\
\text { ocorrências de faltas, região, motivos, quais } \\
\text { cargas não foram ainda embarcadas. }\end{array}$ & & \\
\hline $\begin{array}{l}\text { Existe uma } \\
\text { prática de } \\
\text { reuniões } \\
\text { operacionais } \\
\text { padrão entre } \\
\text { fornecedor e } \\
\text { cliente? }\end{array}$ & $\begin{array}{l}\text { "Temos relatórios semanais e diários. } \\
\text { Reuniões operacionais mensais } \\
\text { trimestrais." } \\
\text { *Ata de reunião com Transportador - foi } \\
\text { mostrada apresentação mensal para o cliente } \\
\text { e ata de reunião no e-mail. }\end{array}$ & $\begin{array}{l}\text { Foi evidenciado } \\
\text { ata das reuniões }\end{array}$ & Formal \\
\hline $\begin{array}{l}\text { Existem regras } \\
\text { padronizadas } \\
\text { com relação aos } \\
\text { riscos de carga } \\
\text { de alto valor? }\end{array}$ & $\begin{array}{l}\text { * Regras de Segurança - é um anexo do } \\
\text { contrato }\end{array}$ & $\begin{array}{l}\text { Foi evidenciado } \\
\text { as regras de } \\
\text { segurança }\end{array}$ & Formal \\
\hline $\begin{array}{c}\text { Contexto } \\
\text { (aplicado a } \\
\text { todas as } \\
\text { dimensões) }\end{array}$ & $\begin{array}{l}\text { "Estão (regras de gerenciamento de risco) no } \\
\text { Plano de Gerenciamento de Risco que é } \\
\text { conhecido de todos os envolvidos no } \\
\text { serviço." } \\
\text { "Minha maior expectativa com relação ao } \\
\text { operador logístico é o indicador OTIF (on } \\
\text { time in full), ou seja, entrega completa, sem } \\
\text { avarias, faltas ou sobras no prazo." }\end{array}$ & $\begin{array}{l}\text { O cliente possui } \\
\text { muita clareza de } \\
\text { quais } \\
\text { principais } \\
\text { indicadores. }\end{array}$ & Formal \\
\hline
\end{tabular}

Conclusão final: 6 itens demonstram que Cialab é fortemente Formalizada

\subsubsection{Eurochain}

\begin{tabular}{|c|c|c|c|}
\hline Critérios & $\begin{array}{c}\text { Trechos da Entrevista, Visitas e } \\
\text { Documentos }\end{array}$ & Análise & Resultado \\
\hline $\begin{array}{l}\text { Preços definidos e } \\
\text { formalizados? }\end{array}$ & $\begin{array}{l}\text { * Tabela de preços - é um anexo do } \\
\text { contrato }\end{array}$ & $\begin{array}{l}\text { Tabela de preços } \\
\text { evidenciada }\end{array}$ & Formal \\
\hline $\begin{array}{l}\text { Níveis de serviços } \\
\text { estão acordados e } \\
\text { formalizados? }\end{array}$ & $\begin{array}{l}\text { *Contrato com fornecedores }-150 \\
\text { páginas de contrato sobre produtos } \\
\text { transportados, serviços comprados, } \\
\text { níveis de serviço, atendimento, } \\
\text { acompanhamento, reuniões e etc. } \\
\text { SLA - Acordo de Nível de Serviço - } \\
\text { estava no contrato, meta de } 98 \% \text {. }\end{array}$ & $\begin{array}{l}\text { SLA - Acordo de } \\
\text { Nível de Serviço - } \\
\text { estava no contrato, } \\
\text { meta de } 98 \% \text { - } \\
\text { evidenciado }\end{array}$ & Formal \\
\hline $\begin{array}{c}\text { Acompanhamento } \\
\text { do nível de } \\
\text { serviço? }\end{array}$ & $\begin{array}{l}\text { Precisa ser confirmado nas entrevistas } \\
\text { na Eurochain. }\end{array}$ & $\begin{array}{l}\text { Precisa ser } \\
\text { confirmado com a } \\
\text { Eurochain }\end{array}$ & - \\
\hline
\end{tabular}




\begin{tabular}{|c|c|c|c|}
\hline $\begin{array}{l}\text { Existe uma } \\
\text { prática de } \\
\text { reuniões } \\
\text { operacionais } \\
\text { padrão entre } \\
\text { fornecedor e } \\
\text { cliente? } \\
\end{array}$ & $\begin{array}{l}\text { "Temos relatórios semanais e diários." } \\
\text { "Reuniões operacionais mensais e } \\
\text { trimestrais." } \\
\text { *Ata de reunião com Transportador - } \\
\text { foi mostrada apresentação mensal para } \\
\text { o cliente e ata de reunião no e-mail. }\end{array}$ & $\begin{array}{l}\text { Foi evidenciado ata } \\
\text { das reuniões }\end{array}$ & Formal \\
\hline $\begin{array}{c}\text { Existem regras } \\
\text { padronizadas com } \\
\text { relação aos riscos } \\
\text { de carga de alto } \\
\text { valor? }\end{array}$ & $\begin{array}{l}\text { Precisa ser confirmado nas entrevistas } \\
\text { na Eurochain. }\end{array}$ & $\begin{array}{l}\text { Precisa ser } \\
\text { confirmado com a } \\
\text { Eurochain }\end{array}$ & - \\
\hline $\begin{array}{c}\text { Contexto } \\
\text { (aplicado a todas } \\
\text { as dimensões) }\end{array}$ & $\begin{array}{l}\text { "Estão (regras de gerenciamento de } \\
\text { risco) no Plano de Gerenciamento de } \\
\text { Risco que é conhecido de todos os } \\
\text { envolvidos no nerviço." } \\
\text { "Minha maior expectativa com relação } \\
\text { ao operador logístico é o indicador } \\
\text { OTIF (on time in full), ou seja, entrega } \\
\text { completa, sem avarias, faltas ou sobras } \\
\text { no prazo." }\end{array}$ & $\begin{array}{l}\text { O cliente possui } \\
\text { muita clareza de } \\
\text { quais os principais } \\
\text { indicadores. }\end{array}$ & Formal \\
\hline
\end{tabular}

Conclusão final: 4 critérios consideram alta formalidade, outros 2 precisam ser confirmados com a Eurochain.

\subsubsection{Integração}

\subsubsection{Cialab - Eurochain}

\begin{tabular}{|c|c|c|c|}
\hline Critérios & $\begin{array}{c}\text { Trechos da Entrevista, Visitas e } \\
\text { Documentos }\end{array}$ & Análise & Resultado \\
\hline $\begin{array}{c}\text { Iniciativas em } \\
\text { conjunto que } \\
\text { proporcionem } \\
\text { benefícios para } \\
\text { ambas as } \\
\text { empresas }\end{array}$ & $\begin{array}{l}\text { "Sindusfarma (Sindicato das indústrias } \\
\text { farmacêuticas) queria que todas as } \\
\text { indústrias se responsabilizassem por } \\
\text { meio de lei sobre a coleta e destruição de } \\
\text { medicamentos vencidos na casa dos } \\
\text { clientes, tivemos grande trabalho para } \\
\text { provar que não era viável. Fora isso, não } \\
\text { temos outros esforços colaborativos." }\end{array}$ & $\begin{array}{l}\text { Empresas do setor } \\
\text { trabalharam em } \\
\text { conjunto para não } \\
\text { aceitar a proposta do } \\
\text { Sindusfarma, mas } \\
\text { não foram iniciativa } \\
\text { colaborativas entre } \\
\text { agentes da cadeia }\end{array}$ & $\begin{array}{c}\text { Sem } \\
\text { Integração }\end{array}$ \\
\hline $\begin{array}{l}\text { Contexto } \\
\text { (aplicado a } \\
\text { todas as } \\
\text { dimensões) }\end{array}$ & $\begin{array}{l}\text { "Operacionalmente falando, posso dizer } \\
\text { sobre os fornecedores, em } 2013 \text { tivemos } \\
\text { grandes dificuldades e problemas na } \\
\text { operação, mas sempre tivemos um bom } \\
\text { histórico." }\end{array}$ & $\begin{array}{l}\text { Um histórico de } \\
\text { relacionamento } \\
\text { longo, porém com } \\
\text { dificuldades recentes }\end{array}$ & Indiferente \\
\hline *Comunicação & $\begin{array}{c}\text { "Reuniões operacionais mensais e } \\
\text { trimestrais." }\end{array}$ & $\begin{array}{l}\text { A comunicação } \\
\text { apresentada é } \\
\text { basicamente } \\
\text { operacional }\end{array}$ & $\begin{array}{c}\text { Sem } \\
\text { Integração }\end{array}$ \\
\hline *Confiança & $\begin{array}{c}\text { "Confiamos na solução que o operador } \\
\text { logístico irá proporcionar." }\end{array}$ & $\begin{array}{c}\text { Confiança não no } \\
\text { relacionamento, mas } \\
\text { na capacidade }\end{array}$ & $\begin{array}{c}\text { Sem } \\
\text { Integração }\end{array}$ \\
\hline
\end{tabular}




\begin{tabular}{|c|c|c|c|} 
& & $\begin{array}{c}\text { operacional do } \\
\text { cliente. }\end{array}$ & \\
\hline * Tempo de & $\begin{array}{c}\text { "Esta conta possui mais de } 10 \text { anos, } \\
\text { tivemos altos e baixos no } \\
\text { relacionamento }\end{array}$ & $\begin{array}{c}\text { Esta conta possui } \\
\text { mais de } 10 \text { anos, um } \\
\text { relacionamento com } \\
\text { foco no longo prazo. }\end{array}$ & Integração \\
\hline
\end{tabular}

Conclusão final: 3 itens demonstram fortemente a falta de integração entre Cialab e a Eurochain .

\subsection{Análise Inter-Empresa}

Esta análise consiste no cruzamento das análises individuais.

\subsubsection{Análise da Centralização}

Abaixo serão analisadas em cada quadro todos os relacionamentos da cadeia, os dados serão cruzados com as opiniões de cada entrevista sobre o mesmo relacionamento.

\subsubsection{Centralização entre Eurochain e Cialab}




\begin{tabular}{|c|c|c|c|c|c|c|}
\hline \multirow[b]{3}{*}{ Critérios } & \multicolumn{4}{|c|}{ Centralização do poder no relacionamento entre Cialab e Eurochain } & & \\
\hline & \multicolumn{2}{|c|}{ Versão da Cialab (Intra-analise) } & \multicolumn{2}{|l|}{ Versão da Eurochain (Intra-analise) } & \multirow{2}{*}{\multicolumn{2}{|c|}{$\begin{array}{l}\text { Resultado final : Relacionamento } \\
\text { Cialab e Eurochain }\end{array}$}} \\
\hline & Análise & Resultado & Análise & \begin{tabular}{|l|} 
Resu \\
ltado
\end{tabular} & & \\
\hline Negociações & $\begin{array}{l}\text { O mecanismo de bônus e multas } \\
\text { descrito é uma mecanismo com foco } \\
\text { na performance e não em gerar } \\
\text { ganhos financeiros. }\end{array}$ & Equilíbrio & $\begin{array}{l}\text { Conforme o entrevistado } 1 \text { e } 2 \\
\text { explicaram neste processo de multa e } \\
\text { bonus, a Eurochain não recebe bônus } \\
\text { por decisão própria e não por } \\
\text { imposição da Cialab. A princípio } \\
\text { haveria multa mais o bônus, ou seja, } \\
\text { seria uma regra que beneficia os dois } \\
\text { lados. }\end{array}$ & $\begin{array}{l}\text { Equil } \\
\text { íbrio }\end{array}$ & Ambos concordam & $\begin{array}{l}\text { Equilí- } \\
\text { brio }\end{array}$ \\
\hline Autonomia & $\begin{array}{l}\text { De acordo com a visão da Cialab, } \\
\text { eles fazem um controle rígido das } \\
\text { questões de segurança da carga, } \\
\text { outros temas que possuem interface } \\
\text { direta com a Cialab, como reuniões } \\
\text { também recebem influência da } \\
\text { própria Cialab. Porém outros temas } \\
\text { operacionais não possuem } \\
\text { interferência direta, sendo que os } \\
\text { fornecedores tem autonomia para } \\
\text { trabalhar dentro das regras legais } \\
\text { para cargas de medicamento. Tanto } \\
\text { a Eurochain quanto seus } \\
\text { fornecedores tem liberdade para } \\
\text { definirem em torno de } 5 \text { elementos, } \\
\text { como contratação de } \\
\text { transportadores, definição de equipe, } \\
\text { veículos e outros. }\end{array}$ & Equilíbrio & $\begin{array}{l}\text { A Eurochain possuiu autonomia sobre } \\
\text { os elementos operacionais do serviço } \\
\text { de transporte na cadeia. }\end{array}$ & $\begin{array}{l}\text { Euro } \\
\text { chain }\end{array}$ & $\begin{array}{l}\text { Embora a Cialab considere } \\
\text { quase a mesma autonomia, } \\
\text { eles classificam que mais } \\
\text { elementos são definidos } \\
\text { pela Eurochain. }\end{array}$ & $\begin{array}{l}\text { Euro- } \\
\text { chain } \\
\text { concen- } \\
\text { tra mais } \\
\text { poder }\end{array}$ \\
\hline Contexto & A Cialab possui somente 2 & Indiferent & Mostra um diálogo aberto entre as duas & Equil & Baseado no dialogo aberto & Equilíbr \\
\hline
\end{tabular}




\begin{tabular}{|c|c|c|c|c|c|c|}
\hline $\begin{array}{c}\text { (aplicado a } \\
\text { todas as } \\
\text { dimensões) }\end{array}$ & $\begin{array}{l}\text { fornecedores, porém a Eurochain é a } \\
\text { principal, só mantiveram o segundo } \\
\text { para não haver risco das cargas de } \\
\text { amostra grátis ficarem em sem } \\
\text { atenção da Eurochain. }\end{array}$ & $\mathrm{e}$ & empresas. & íbrio & & io \\
\hline $\begin{array}{c}\text { *Importân- } \\
\text { cia de uma } \\
\text { empresa } \\
\text { para a outra }\end{array}$ & $\begin{array}{l}\text { A performance da Eurochain tem } \\
\text { uma importância estratégica para } \\
\text { não perder vendas por quebra (falta } \\
\text { de produtos) de gôndola nas } \\
\text { farmâcias, porém isso não aumenta } \\
\text { o poder de negociação da Eurochain } \\
\text { e sim sua responsabilidade. }\end{array}$ & $\begin{array}{c}\text { Indiferent } \\
\mathrm{e}\end{array}$ & $\begin{array}{l}\text { A Cialab é um cliente chave para a } \\
\text { Eurochain, um problema pode envolver } \\
\text { a alta hierarquia da Eurochain, gera } \\
\text { inovações para a Eurochain também. }\end{array}$ & $\begin{array}{c}\text { Ciala } \\
\mathrm{b}\end{array}$ & $\begin{array}{l}\text { Para a Cialab perder um } \\
\text { fornecedor igual a } \\
\text { Eurochain é um impacto } \\
\text { muito grande, mas talvez } \\
\text { menor que que a Eurochain } \\
\text { perder um cliente } \\
\text { referência. }\end{array}$ & $\begin{array}{l}\text { Cialab } \\
\text { concen- } \\
\text { tra mais } \\
\text { poder }\end{array}$ \\
\hline $\begin{array}{l}\text { *Participa- } \\
\text { ção no } \\
\text { faturamento }\end{array}$ & $\begin{array}{l}\text { 100\% dos produtos vendidos, (não } \\
\text { amostra grátis), são distribuídos pela } \\
\text { Eurochain, isso concentra poder na } \\
\text { mão da Eurochain, pois em caso de } \\
\text { desacordo a Cialab não consegue } \\
\text { facilmente trocar de fornecedor. }\end{array}$ & Eurochain & $\begin{array}{l}\text { A Cialab corresponde a } 1 / 4 \text { do } \\
\text { faturamento do setor farmacêutico da } \\
\text { Eurochain, é uma conta muito } \\
\text { importante. }\end{array}$ & $\begin{array}{c}\text { Ciala } \\
\mathrm{b}\end{array}$ & $\begin{array}{l}\text { Em termos de faturamento } \\
\text { perdido e fornecedor } \\
\text { perdido, não é possível } \\
\text { dizer para qual é pior. }\end{array}$ & $\begin{array}{l}\text { Equilí- } \\
\text { brio }\end{array}$ \\
\hline \multicolumn{3}{|c|}{$\begin{array}{l}\text { Resultado Final: } 1 \text { itens elegem a Eurochain, assim a Eurochain } \\
\text { concentra levemente o poder na relação. }\end{array}$} & \multicolumn{2}{|c|}{$\begin{array}{l}\text { Resultado Final: } 2 \text { itens elegem a Cialab e } 1 \\
\text { item elege a Eurochain, assim a Cialab } \\
\text { concentra leventemente o poder na relação. }\end{array}$} & $\begin{array}{l}\text { Resultado Final: A Cialab é } \\
\text { essencial para Eurochain } \\
\text { pelo autofaturamento e } \\
\text { pelas inovações e } \\
\text { benchmarking. } \\
\text { A Eurochain é essencial } \\
\text { para a Cialab, pois é o } \\
\text { fornecedor em quem eles } \\
\text { tem depositado 100\% da } \\
\text { distribuiçã ode seu } \\
\text { faturamento há mais de } 15 \\
\text { anos e confiam a autonomia } \\
\text { da operação no controle } \\
\text { deles }\end{array}$ & $\begin{array}{l}\text { Equi- } \\
\text { líbrio }\end{array}$ \\
\hline
\end{tabular}




\subsubsection{Centralização entre Eurochain e Air Cargo}

\begin{tabular}{|c|c|c|c|c|c|c|}
\hline \multirow[b]{3}{*}{ Critérios } & \multicolumn{4}{|c|}{ Centralização do poder no relacionamento entre Eurochain e Air Cargo } & & \\
\hline & \multicolumn{2}{|c|}{ Versão da Eurochain (Intra-analise) } & \multicolumn{2}{|l|}{ Versão da Air Cargo (Intra-analise) } & \multirow{2}{*}{\multicolumn{2}{|c|}{$\begin{array}{l}\text { Resultado final : } \\
\text { Relacionamento Cialab e } \\
\text { Eurochain }\end{array}$}} \\
\hline & Análise & $\begin{array}{c}\text { Resultad } \\
\text { o }\end{array}$ & Análise & Resultado & & \\
\hline Negociações & $\begin{array}{l}\text { Os entrevistados } 1 \text { e } 2 \text { dizem } \\
\text { que não são ditadores, mas } \\
\text { que dão uma forçada, } \\
\text { também citou } 2 \text { vezes que se } \\
\text { o fornecedor não conseguir } \\
\text { provar a culpa já é dele, e ele } \\
\text { terá de ressarcir, ou seja, é o } \\
\text { elo mais fraco. }\end{array}$ & $\begin{array}{l}\text { Euro- } \\
\text { chain }\end{array}$ & $\begin{array}{l}\text { Por duas vezes durante a entrevista foi citado a grande } \\
\text { dificuldade que a Air Cargo possui nas negociações de } \\
\text { preços, ou seja, eles são a parte mais fraca na } \\
\text { negociação. } \\
\text { Nessa negociação operacional o custo ficou para a Air } \\
\text { Cargo, foram mais uma vez mais fracos }\end{array}$ & Eurochain & Ambos de acordo & $\begin{array}{l}\text { Euro- } \\
\text { chain } \\
\text { concen- } \\
\text { tra mais } \\
\text { poder }\end{array}$ \\
\hline Autonomia & $\begin{array}{c}\text { Embora o transportador } \\
\text { tenha algumas opções de } \\
\text { escolha operacional, quem } \\
\text { define a maior parte dos } \\
\text { elementos da operação é a } \\
\text { Eurochain. Inclusive pode } \\
\text { pedir para trocar um } \\
\text { fornecedor contratado pela } \\
\text { Air Cargo }\end{array}$ & $\begin{array}{l}\text { Euro- } \\
\text { chain }\end{array}$ & $\begin{array}{l}\text { O processo comercial da Air Cargo que é essencial para } \\
\text { o seu crescimento é limitado pela Eurochain. A } \\
\text { Eurochain possui grande influência. } \\
\text { O questionário também mostra a alta influência da } \\
\text { Eurochain nas tomadas de decisão dos elementos } \\
\text { operacionais. }\end{array}$ & Eurochain & Ambos de acordo & $\begin{array}{l}\text { Euro- } \\
\text { chain } \\
\text { concen- } \\
\text { tra mais } \\
\text { poder }\end{array}$ \\
\hline $\begin{array}{l}\text { Contexto } \\
\text { (aplicado a } \\
\text { todas as } \\
\text { dimensões) }\end{array}$ & $\begin{array}{l}\text { A Eurochain possui um foco } \\
\text { de longo prazo nos } \\
\text { relacionamentos, mas } \\
\text { possuiu diversas opções de } \\
\text { transportadores em torno de }\end{array}$ & $\begin{array}{l}\text { Equilí- } \\
\text { brio }\end{array}$ & $\begin{array}{l}\text { (nenhuma informação importante que não tenha sido } \\
\text { discutida nos outros critérios) }\end{array}$ & $\begin{array}{l}\text { Descon- } \\
\text { siderado }\end{array}$ & $\begin{array}{l}\text { baseado somente na } \\
\text { Eurochain }\end{array}$ & $\begin{array}{l}\text { Equili- } \\
\text { brio }\end{array}$ \\
\hline
\end{tabular}




\begin{tabular}{|c|c|c|c|c|c|c|}
\hline & 80 & & & & & \\
\hline $\begin{array}{l}\text { *Importân- } \\
\text { cia de uma } \\
\text { empresa } \\
\text { para a outra }\end{array}$ & $\begin{array}{l}\text { Devido o foco de longo } \\
\text { prazo da Eurochain em } \\
\text { desenvolver os fornecedores, } \\
\text { esses ganham mais } \\
\text { importância. }\end{array}$ & $\begin{array}{l}\text { Equilí- } \\
\text { brio }\end{array}$ & $\begin{array}{l}\text { Para a Air Cargo a Eurochain é muito importante } \\
\text { estratégicamente para consolidar sua posição no } \\
\text { mercado de farmacêutico, além de dar lucro. É uma } \\
\text { pressão sobre eles manter essa conta. } \\
\text { A Air Cargo entende que existe um bom } \\
\text { relacionamento, que eles são bons fornecedores e } \\
\text { ganharam espaço dentro da Eurochain, detem agora } \\
80 \% \text { do frete aéreo deles. Além disso o mercado é } \\
\text { restrito e eles são uma das empresas de transporte aéreo } \\
\text { mais importantes do país. } \\
\text { A visita mostra que em termos de espaço de armazém a } \\
\text { Air Cargo possuiu inúmeros outros clientes mais } \\
\text { volumosos. } \\
\text { Para a Eurochain mudar de fornecedor pode ser difícil, } \\
\text { mas para a Air Cargo achar outra conta igual é mais } \\
\text { difícil. }\end{array}$ & Eurochain & $\begin{array}{c}\text { A Eurochain } \\
\text { possuiu muita } \\
\text { confiança e tem } \\
\text { confiado mais } \\
\text { volume para a Air } \\
\text { Cargo, porém a Air } \\
\text { Cargo possui uma } \\
\text { dependência } \\
\text { estratégica da da } \\
\text { Eurochain para se } \\
\text { manter no setor } \\
\text { farmacêutico. }\end{array}$ & $\begin{array}{l}\text { Euro- } \\
\text { chain } \\
\text { concen- } \\
\text { tra mais } \\
\text { poder }\end{array}$ \\
\hline $\begin{array}{l}\text { *Participa- } \\
\text { ção no } \\
\text { faturamento }\end{array}$ & $\begin{array}{l}\text { Considerando que a Air } \\
\text { Cargo é responsável por } \\
\text { somente } 90 \% \text { do volume } \\
\text { aéreo do Farmacêutico, não } \\
\text { só da Cialab, eles possuem } \\
\text { muita influência na } \\
\text { Eurochain. }\end{array}$ & $\begin{array}{c}\text { Air } \\
\text { Cargo }\end{array}$ & $\begin{array}{l}\text { Mesmo a Air Cargo tendo } 80 \% \text { do aéreo da Eurochain. } \\
\text { O peso da representatividade na Air Cargo } \\
\text { Farmacêutico é enorme, a Eurochain é } 90 \% \text { do } \\
\text { faturamento da Air Cargo. Para a Eurochain mudar de } \\
\text { fornecedor pode ser difícil, mas para a Air Cargo achar } \\
\text { outra conta igual é mais difícil. }\end{array}$ & Eurochain & $\begin{array}{c}\text { Embora 90\% do } \\
\text { aéreo da Eurochain } \\
\text { esteja com a Air } \\
\text { Cargo, A Air Cargo } \\
\text { possui uma } \\
\text { dependência de } \\
\text { sobrevivência no } \\
\text { setor. }\end{array}$ & $\begin{array}{l}\text { Euro- } \\
\text { chain } \\
\text { concen- } \\
\text { tra mais } \\
\text { poder }\end{array}$ \\
\hline & \multicolumn{2}{|c|}{$\begin{array}{l}\text { Resultado Final: Dos cinco critérios } \\
\text { levados em consideração, } 2 \\
\text { consideram a Eurochain como } \\
\text { concentrador de poder, e um considera }\end{array}$} & \multicolumn{2}{|c|}{$\begin{array}{l}4 \text { itens a favor da Eurochain, } 0 \text { a favor da Air Cargo. Resultado } \\
\text { final alta concetração de poder na Eurochain }\end{array}$} & $\begin{array}{l}\text { A Air Cargo } \\
\text { possui uma } \\
\text { dependência } \\
\text { estratégica da da }\end{array}$ & $\begin{array}{c}\text { Alta } \\
\text { Centra- } \\
\text { lização } \\
\text { na }\end{array}$ \\
\hline
\end{tabular}




\begin{tabular}{|c|c|}
\hline $\begin{array}{c}\text { a Air Cargo. Assim, a Eurochain } \\
\text { concentra levemente o poder na } \\
\text { relação. }\end{array}$ & $\begin{array}{l}\text { Eurochain para se } \\
\text { manter no setor } \\
\text { farmacêutico. } \\
\text { Além disso as } \\
\text { reclamações de } \\
\text { preços, a } \\
\text { autonomia e a } \\
\text { obrigação de ter } \\
\text { que provar que é } \\
\text { chain } \\
\text { inocente para não } \\
\text { pagar, comprovam } \\
\text { o grande poder da } \\
\text { Eurochain }\end{array}$ \\
\hline
\end{tabular}


5.10.1.3. Centralização entre Air Cargo e Companhias Aéreas

\begin{tabular}{|c|c|c|}
\hline & \multicolumn{2}{|c|}{ Centralização do poder no relacionamento entre Air Cargo e Cia Aéreas } \\
\hline & \multicolumn{2}{|l|}{ Versão da Air Cargo } \\
\hline Critérios & Análise & Resultado \\
\hline Negociações & $\begin{array}{l}\text { A Air Cargo perdeu dinheiro com carga roubada e existem só } 2 \text { fornecedores no } \\
\text { mercado. } \\
\text { Colocam um funcionário próxima a companhia para ter mais influência, mas é só. }\end{array}$ & $\begin{array}{l}\text { Cia Aérea concentra } \\
\text { mais poder }\end{array}$ \\
\hline Autonomia & $\begin{array}{c}\text { A Air Cargo segue a programação das companhias aéreas, não tem influência sobre } \\
\text { rotas, horários ou modelos de aviões }\end{array}$ & $\begin{array}{l}\text { Cia Aérea concentra } \\
\text { mais poder }\end{array}$ \\
\hline $\begin{array}{l}\text { Contexto (aplicado a } \\
\text { todas as dimensões) }\end{array}$ & $\begin{array}{l}\text { Por meio do foca e de bom relacionamento conseguem algumas vantagens } \\
\text { operacionais com as companhias aéreas, mas isso não significa concentração de poder }\end{array}$ & Equilíbrio \\
\hline $\begin{array}{l}\text { *Importância de uma } \\
\text { empresa para a outra }\end{array}$ & $\begin{array}{c}\text { A Air Cargo possui alto volume, porém as Cia Aéreas com bom serviço são somente } \\
\text { duas. }\end{array}$ & Equilíbrio \\
\hline $\begin{array}{l}\text { *Participação no } \\
\text { faturamento }\end{array}$ & $\begin{array}{c}\text { Não temos dados do percentual do faturamento da companhia aérea. Mas pela } \\
\text { prioridade de cargas sabemos que em primeiro lugar vem as bagagens dos passageiros } \\
\text { e depois a carga aérea, isso parece ser um indício de que a primeira receita é em } \\
\text { passageiros. Para a Air Cargo é muito importante, } 83 \% \text { dos seus custos de frete estão } \\
\text { em um fornecedor }\end{array}$ & $\begin{array}{l}\text { Cia Aérea concentra } \\
\text { mais poder }\end{array}$ \\
\hline & \multicolumn{2}{|c|}{$\begin{array}{l}\text { A Cia Aérea possui Alta Centralização de poder sobre a Air Cargo, } 3 \text { pontos a favor da Cia Aérea e } 2 \text { em } \\
\text { equilíbrio. A Cia Aérea tem sua atividade principal o transporte de pessoas, por isso a poder dos clientes de } \\
\text { carga é menor. }\end{array}$} \\
\hline
\end{tabular}


5.10.1.4. Centralização entre Air Cargo e Transportadores Rodoviários

\begin{tabular}{|c|c|c|}
\hline & \multicolumn{2}{|c|}{ Centralização do poder no relacionamento entre Air Cargo e Transportadores Rodoviários } \\
\hline & \multicolumn{2}{|c|}{ Versão da Air Cargo } \\
\hline Critérios & Análise & Resultado \\
\hline Negociações & $\begin{array}{l}\text { Em casos de menor impacto a Air Cargo dá liberdade para os } \\
\text { transportadores trabalharem fora do padrão. Porém em casos mais } \\
\text { difíceis, nenhuma dos lados cedeu e a parceria foi rompida. }\end{array}$ & Equilíbrio \\
\hline Autonomia & $\begin{array}{l}\text { O questionário mostra uma maior influência da Air Cargo. Porém a Air } \\
\text { Cargo também abre exceções }\end{array}$ & $\begin{array}{l}\text { Air Cargo concentra } \\
\text { mais poder }\end{array}$ \\
\hline $\begin{array}{l}\text { Contexto (aplicado a } \\
\text { todas as dimensões) }\end{array}$ & Indiferente & Indiferente \\
\hline $\begin{array}{l}\text { *Importância de } \\
\text { uma empresa para a } \\
\text { outra }\end{array}$ & $\begin{array}{l}\text { Nenhuma informação relevante foi fornecida com relação a volumes ou } \\
\text { estratégia ou número restrito de fornecedores }\end{array}$ & Desconsiderado \\
\hline $\begin{array}{l}\text { *Participação no } \\
\text { faturamento }\end{array}$ & (sem informações disponíveis) & Desconsiderado \\
\hline & $\begin{array}{r}\text { Air Cargo possui Baixa Centralização sobre os transportadores rodov } \\
\text { critérios um a favor da Air Cargo, critério de autonomia c }\end{array}$ & $\begin{array}{l}\text { os, mas é pouca. De } 3 \\
\text { acional. }\end{array}$ \\
\hline
\end{tabular}


5.10.1.5. Centralização entre Sul Deste Cargo e Eurochain

\begin{tabular}{|c|c|c|c|c|c|c|}
\hline \multirow[b]{3}{*}{ Critérios } & \multicolumn{4}{|c|}{ Centralização do poder no relacionamento entre Eurochain e Sul Deste Cargo } & & \\
\hline & \multicolumn{2}{|c|}{ Versão Eurochain (Intra-analise) } & \multicolumn{2}{|c|}{ Versão Sul Deste Cargo (Intra-analise) } & \multirow{2}{*}{\multicolumn{2}{|c|}{$\begin{array}{l}\text { Resultado final : Relacionamento } \\
\text { Cialab e Eurochain }\end{array}$}} \\
\hline & Análise & $\begin{array}{c}\text { Resultad } \\
\text { o }\end{array}$ & Análise & $\begin{array}{c}\text { Result } \\
\text { ado }\end{array}$ & & \\
\hline Negociações & $\begin{array}{l}\text { Os entrevistados } 1 \text { e } 2 \text { dizem que } \\
\text { não são ditadores, mas que dão } \\
\text { uma forçada, também citou } 2 \text { vezes } \\
\text { que se o fornecedor não conseguir } \\
\text { provar a culpa já é dele, e ele terá } \\
\text { de ressarcir, ou seja, é o elo mais } \\
\text { fraco. }\end{array}$ & $\begin{array}{l}\text { Euro- } \\
\text { chain }\end{array}$ & $\begin{array}{l}\text { A Sul Deste Cargo reclama dos preços } \\
\text { baixos pagos, no qual provavelmente foi } \\
\text { uma negociação que não os agradou } \\
\text { muito. Quando existe erro de } \\
\text { faturamento eles tem o pagamento } \\
\text { atrasado. Recentemente a Sul Deste } \\
\text { Cargo começou a ter multas, porém não } \\
\text { recebe bônus, ou seja, só perde. É o lado } \\
\text { fraco da negociação. }\end{array}$ & $\begin{array}{l}\text { Euro- } \\
\text { chain }\end{array}$ & Ambos de Acordo & $\begin{array}{l}\text { Eurochain } \\
\text { concentra } \\
\text { mais poder }\end{array}$ \\
\hline Autonomia & $\begin{array}{l}\text { Embora o transportador tenha } \\
\text { algumas opções de escolha } \\
\text { operacional, quem define a maior } \\
\text { parte dos elementos da operação é } \\
\text { a Eurochain. Inclusive pode pedir } \\
\text { para trocar um fornecedor } \\
\text { contratado pela Sul Deste Cargo }\end{array}$ & $\begin{array}{l}\text { Euro- } \\
\text { chain }\end{array}$ & $\begin{array}{l}\text { A Eurochain possui influência em torno } \\
\text { de } 5 \text { itens, mas todos itens operacionais } \\
\text { que envolvem ela como as reuniões, ou } \\
\text { então o destinatário, ou seja, itens nos } \\
\text { quais é natural a interferência externa. } \\
\text { Todas as outras variáveis são de escolha } \\
\text { da Sul Deste Cargo, assim a autonomia } \\
\text { da Sul Deste Cargo é alta } \\
\end{array}$ & $\begin{array}{c}\text { Sul } \\
\text { Deste } \\
\text { Cargo }\end{array}$ & $\begin{array}{l}\text { Neste caso a } \\
\text { avaliação de cada } \\
\text { parte é contrária, } \\
\text { não é possível } \\
\text { distinguir qual dos } \\
\text { dois agentes está } \\
\text { correto. }\end{array}$ & $\begin{array}{l}\text { Desconside- } \\
\quad \text { rado }\end{array}$ \\
\hline $\begin{array}{l}\text { Contexto } \\
\text { (aplicado a } \\
\text { todas as } \\
\text { dimensões) }\end{array}$ & $\begin{array}{l}\text { A Eurochain possui um foco de } \\
\text { longo prazo nos relacionamentos, } \\
\text { mas possuiu diversas opções de } \\
\text { transportadores em torno de } 80\end{array}$ & $\begin{array}{l}\text { Equilí- } \\
\text { brio }\end{array}$ & $\begin{array}{l}\text { A Sul Deste Cargo enxerga que o } \\
\text { relacionamento com a Eurochain é bom, } \\
\text { porém quando a indústria e seus clientes } \\
\text { possuem alguma demanda eles acabam } \\
\text { cedendo. }\end{array}$ & $\begin{array}{l}\text { Indife- } \\
\text { rente }\end{array}$ & $\begin{array}{l}\text { Com relação ao } \\
\text { contexto ambas } \\
\text { enxergam um } \\
\text { relacionamento } \\
\text { bom. }\end{array}$ & Equilíbrio \\
\hline
\end{tabular}




\begin{tabular}{|c|c|c|c|c|c|c|}
\hline $\begin{array}{l}\text { *Importân- } \\
\text { cia de uma } \\
\text { empresa } \\
\text { para a outra }\end{array}$ & $\begin{array}{l}\text { Devido o foco de longo prazo da } \\
\text { Eurochain em desenvolver os } \\
\text { fornecedores, esses ganham mais } \\
\text { importância. }\end{array}$ & $\begin{array}{l}\text { Equilí- } \\
\text { brio }\end{array}$ & $\begin{array}{l}\text { Do ponto de vista da Sul Deste Cargo, a } \\
\text { Eurochain é uma conta muito } \\
\text { importante. }\end{array}$ & $\begin{array}{l}\text { Euro- } \\
\text { chain }\end{array}$ & $\begin{array}{l}\text { A importância da } \\
\text { Eurochain como } \\
\text { um conjunto de } \\
\text { contas é mais Sul } \\
\text { Deste Cargo. }\end{array}$ & $\begin{array}{l}\text { Eurochain } \\
\text { concentra } \\
\text { mais poder }\end{array}$ \\
\hline \multirow[t]{2}{*}{$\begin{array}{l}\text { *Participa- } \\
\text { ção no } \\
\text { faturamento }\end{array}$} & $\begin{array}{l}\text { Considerando que a Sul Deste } \\
\text { Cargo é responsável por somente } \\
\text { 2,5\% do volume da Cialab, ele tem } \\
\text { pouco poder dentro da Eurochain. }\end{array}$ & $\begin{array}{l}\text { Euro- } \\
\text { chain }\end{array}$ & $\begin{array}{l}\text { A Eurochain representa em torno de } \\
60 \% \text { do faturamento de um importante } \\
\text { setor, que é o farmacêutico. }\end{array}$ & $\begin{array}{l}\text { Euro- } \\
\text { chain }\end{array}$ & Ambos de Acordo & $\begin{array}{l}\text { Eurochain } \\
\text { concentra } \\
\text { mais poder }\end{array}$ \\
\hline & \multicolumn{2}{|c|}{$\begin{array}{l}\text { Resultado Final: Dos cinco critérios levados } \\
\text { em consideração, } 3 \text { consideram a Eurochain } \\
\text { como concentrador de poder, e nenhum } \\
\text { considera a Sul Deste Cargo. Assim, a } \\
\text { Eurochain concentra fortemente o poder na } \\
\text { relação. }\end{array}$} & \multicolumn{2}{|c|}{$\begin{array}{c}\text { Resultado Final: } 3 \text { itens elegem a Eurochain e } 1 \\
\text { item elege a Sul Deste Cargo, assim a Eurochain } \\
\text { concentra fortemente o poder na relação. }\end{array}$} & $\begin{array}{l}\text { Considerando a } \\
\text { dependência da } \\
\text { Sul Deste Cargo, a } \\
\text { reclamação por } \\
\text { pagamento baixo e } \\
\text { as imposições de } \\
\text { custo da } \\
\text { Eurochain, fica } \\
\text { claro que a } \\
\text { Eurochain é quem } \\
\text { concentra poder. }\end{array}$ & $\begin{array}{l}\text { Alta } \\
\text { Centraliza- } \\
\text { ção na } \\
\text { Eurochain }\end{array}$ \\
\hline
\end{tabular}


5.10.1.6. Centralização entre Sul Deste Cargo e Transportadores

\begin{tabular}{|c|c|c|}
\cline { 2 - 3 } \multicolumn{1}{c|}{} & \multicolumn{2}{c|}{ Centralização do poder no relacionamento entre Sul Deste Cargo e Transportadores } \\
Rodoviários
\end{tabular}




\subsubsection{Formalização entre Cialab e Eurochain}

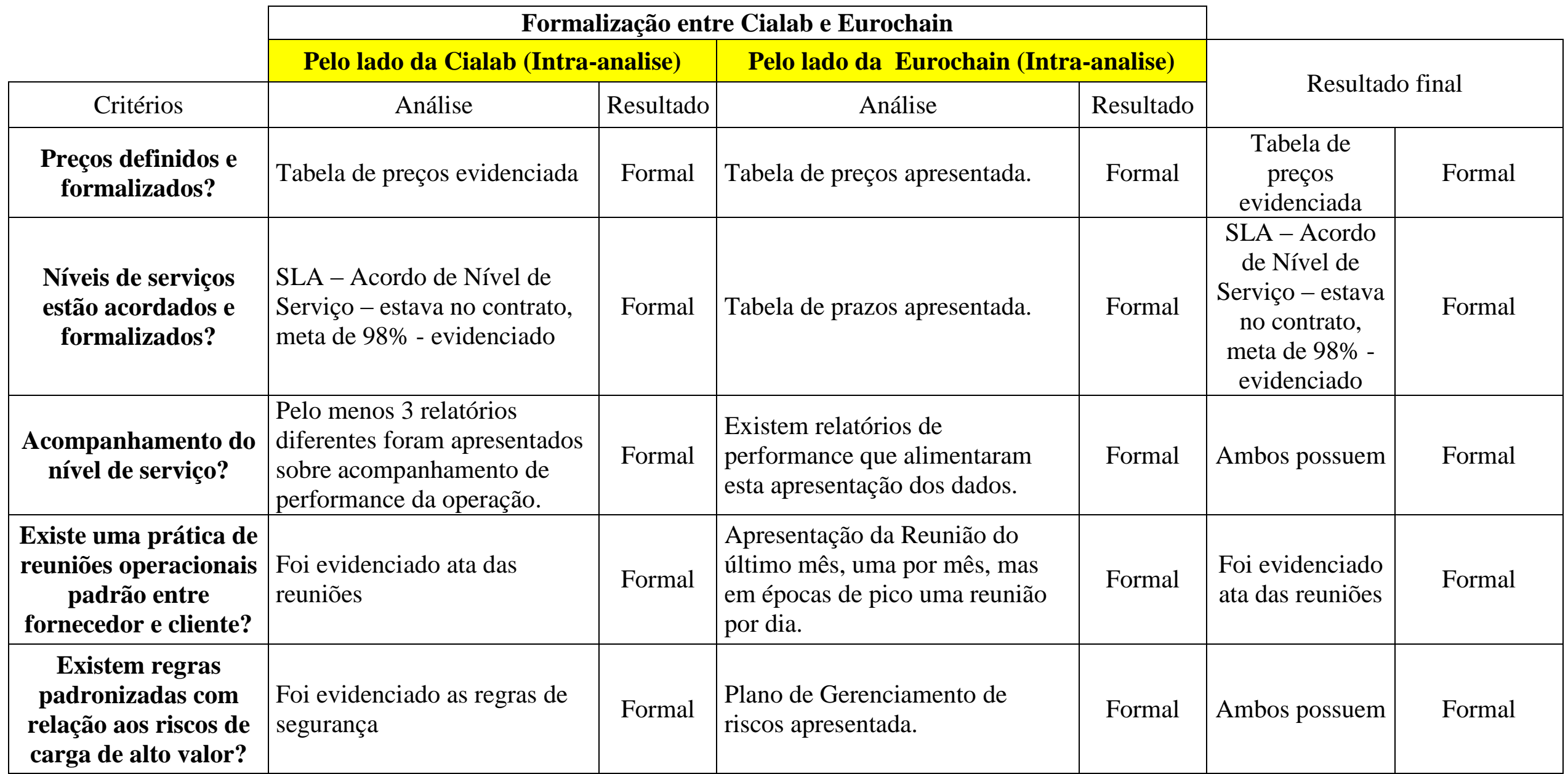




\begin{tabular}{|c|c|c|c|c|c|c|}
\hline $\begin{array}{l}\text { Contexto (aplicado a } \\
\text { todas as dimensões) }\end{array}$ & $\begin{array}{l}\text { O cliente possui muita clareza } \\
\text { de quais os principais } \\
\text { indicadores. }\end{array}$ & Formal & $\begin{array}{l}\text { Apresentado outro controle de } \\
\text { prazo para orientação do cliente }\end{array}$ & Indiferente & $\begin{array}{c}\text { O cliente possui } \\
\text { muita clareza de } \\
\text { quais os } \\
\text { principais } \\
\text { indicadores. }\end{array}$ & $\begin{array}{c}\text { Alta } \\
\text { Formalização }\end{array}$ \\
\hline & \multicolumn{2}{|c|}{$\begin{array}{l}\text { Resultado Final: } 6 \text { itens demonstram que } \\
\text { Cialab é fortemente Formalizada }\end{array}$} & \multicolumn{2}{|c|}{$\begin{array}{l}\text { Resultado Final: } 5 \text { itens demonstram que a } \\
\text { Eurochain é fortemente Formalizada }\end{array}$} & & \\
\hline
\end{tabular}

5.10.2.2. Formalização entre Eurochain e Air Cargo 


\begin{tabular}{|c|c|c|c|c|c|c|}
\hline \multirow[b]{3}{*}{ Critérios } & \multicolumn{4}{|c|}{ Formalizacão entre Eurochain e Air Cargo } & & \\
\hline & \multicolumn{2}{|c|}{ Pelo lado da Eurochain (Intra-analise) } & \multicolumn{2}{|c|}{ Pelo lado da Air Cargo (Intra-analise) } & \multirow{2}{*}{\multicolumn{2}{|c|}{ Resultado final }} \\
\hline & Análise & $\begin{array}{c}\text { Resultad } \\
\text { o }\end{array}$ & Análise & $\begin{array}{c}\text { Result } \\
\text { ado }\end{array}$ & & \\
\hline $\begin{array}{l}\text { Preços definidos e } \\
\text { formalizados? }\end{array}$ & $\begin{array}{l}\text { As tabelas de preços do aéreo foram } \\
\text { evidenciadas }\end{array}$ & Formal & $\begin{array}{l}\text { Não sei se a tabela não foi } \\
\text { mostrada porque não havia ou } \\
\text { por sigilo de informação }\end{array}$ & $\begin{array}{c}\text { Desco } \\
\text { nsidera } \\
\text { do }\end{array}$ & $\begin{array}{c}\text { As tabelas de preços do } \\
\text { aéreo foram } \\
\text { evidenciadas }\end{array}$ & Formal \\
\hline $\begin{array}{c}\text { Níveis de serviços } \\
\text { estão acordados e } \\
\text { formalizados? }\end{array}$ & $\begin{array}{l}\text { As tabelas de prazos foram } \\
\text { evidenciadas }\end{array}$ & Formal & $\begin{array}{l}\text { Sim a meta era manter } 98 \% \text { de } \\
\text { entregas bem sucedidas (prazo e } \\
\text { integridade) }\end{array}$ & Formal & $\begin{array}{l}\text { As tabelas de prazos } \\
\text { foram evidenciadas }\end{array}$ & Formal \\
\hline $\begin{array}{l}\text { Acompanhamento } \\
\text { do nível de } \\
\text { serviço? }\end{array}$ & $\begin{array}{l}\text { Ata de acompanhamento de } \\
\text { problemas operacionais }\end{array}$ & Formal & $\begin{array}{l}\text { o relatório mostra o } \\
\text { acompanhamento semanal }\end{array}$ & Formal & $\begin{array}{c}\text { Ata de acompanhamento } \\
\text { de problemas } \\
\text { operacionais }\end{array}$ & Formal \\
\hline $\begin{array}{c}\text { Existe uma prática } \\
\text { de reuniões } \\
\text { operacionais } \\
\text { padrão entre } \\
\text { fornecedor e } \\
\text { cliente? }\end{array}$ & $\begin{array}{l}\text { As atas de reuniões deixam bem } \\
\text { claro as metas para os fornecedores. }\end{array}$ & Formal & Sim, reunião mensal & Formal & $\begin{array}{l}\text { As atas de reuniões } \\
\text { deixam bem claro as } \\
\text { metas para os } \\
\text { fornecedores. }\end{array}$ & Formal \\
\hline $\begin{array}{c}\text { Existem regras } \\
\text { padronizadas com } \\
\text { relação aos riscos } \\
\text { de carga de alto } \\
\text { valor? }\end{array}$ & $\begin{array}{l}\text { A Eurochain com certeza possui as } \\
\text { regras de de gerenciamento de risco, } \\
\text { porém para checar esse item do } \\
\text { fornecedor, somente na entrevista do } \\
\text { fornecedor. }\end{array}$ & $\begin{array}{l}\text { Desconsi } \\
\text { derado }\end{array}$ & $\begin{array}{l}\text { Documento com todas as regras } \\
\text { inclusive as da Cialab }\end{array}$ & Formal & $\begin{array}{l}\text { Documento com todas as } \\
\text { regras inclusive as da } \\
\text { Cialab }\end{array}$ & Formal \\
\hline $\begin{array}{c}\text { Contexto (aplicado } \\
\text { a todas as } \\
\text { dimensões) }\end{array}$ & $\begin{array}{l}\text { De acordo com ao alto risco deste } \\
\text { transporte, e um processo rigoroso } \\
\text { de seleção de fornecedores, é } \\
\text { coerente que haja um } \\
\text { acompanhamento formal da } \\
\text { operação. }\end{array}$ & Formal & $\begin{array}{l}\text { Existe muita cobrança por } \\
\text { formalização e padronização } \\
\text { quanto mais próximo da } \\
\text { indústria, mas nos } \\
\text { transportadores finais parece } \\
\text { haver maior flexibilidade }\end{array}$ & $\begin{array}{c}\text { Indifer } \\
\text { ente }\end{array}$ & $\begin{array}{l}\text { De acordo com ao alto } \\
\text { risco deste transporte, } \mathrm{e} \\
\text { um processo rigoroso de } \\
\text { seleção de fornecedores, } \\
\text { é coerente que haja um } \\
\text { acompanhamento formal }\end{array}$ & $\begin{array}{c}\text { Alta } \\
\text { Forma } \\
\text { liza- } \\
\text { ção }\end{array}$ \\
\hline
\end{tabular}


5 critérios são formalizados entre Eurochain e

De 5 critérios considerados 4 mostram Air Cargo formalidade. Alta formalidade

5.10.2.3. Formalização entre Air Cargo e Companhias Aéreas

\begin{tabular}{|c|c|c|}
\hline & \multicolumn{2}{|l|}{ Formalização entre Air Cargo e Cia Aéreas } \\
\hline & \multicolumn{2}{|l|}{ Somente pelo lado da Air Cargo } \\
\hline Critérios & Análise & Resultado \\
\hline $\begin{array}{l}\text { Preços definidos e } \\
\text { formalizados? }\end{array}$ & Tabela exibida & Formal \\
\hline $\begin{array}{l}\text { Níveis de serviços } \\
\text { estão acordados e } \\
\text { formalizados? }\end{array}$ & Não existe esse controle & Informal \\
\hline $\begin{array}{l}\text { Acompanhamento } \\
\text { do nível de serviço? }\end{array}$ & Não existe esse controle & Informal \\
\hline $\begin{array}{c}\text { Existe uma prática } \\
\text { de reuniões } \\
\text { operacionais padrão } \\
\text { entre fornecedor e } \\
\text { cliente? }\end{array}$ & Não existe essa prática & Informal \\
\hline $\begin{array}{l}\text { Existem regras } \\
\text { padronizadas com } \\
\text { relação aos riscos de } \\
\text { carga de alto valor? }\end{array}$ & Não existe esse controle & Informal \\
\hline $\begin{array}{l}\text { Contexto (aplicado a } \\
\text { todas as dimensões) }\end{array}$ & $\begin{array}{l}\text { Para a contratação foi evidenciado um controle rigoroso, mas uma vez contratado os } \\
\text { processos de acompanhamento e procedimentos não são formalizados }\end{array}$ & Informal \\
\hline
\end{tabular}


5.10.2.4. Formalização entre Air Cargo e Transportadores Rodoviários

\begin{tabular}{|c|c|c|}
\hline & \multicolumn{2}{|c|}{ Formalização entre Air Cargo e Transportadores Rodoviários } \\
\hline & \multicolumn{2}{|l|}{ Somente pelo lado da Air Cargo } \\
\hline Critérios & Análise & Resultado \\
\hline $\begin{array}{l}\text { Preços definidos e } \\
\text { formalizados? }\end{array}$ & $\begin{array}{l}\text { Não é possível determinar se tabela não foi mostrada porque não havia } \\
\text { ou por sigilo de informação }\end{array}$ & Desconsiderado \\
\hline $\begin{array}{l}\text { Níveis de serviços } \\
\text { estão acordados e } \\
\text { formalizados? }\end{array}$ & $\begin{array}{l}\text { Desconsiderar esse critério, pois as rotas e horários nunca são fixos para } \\
\text { companhias aéreas. }\end{array}$ & Desconsiderado \\
\hline $\begin{array}{l}\text { Acompanhamento } \\
\text { do nível de serviço? }\end{array}$ & $\begin{array}{l}\text { Não foi mostrado nenhuma evidência desse controle, somente na visita } \\
\text { foi evidenciado que algumas pessoas controlam o status dos voôs, mas } \\
\text { nenhum relatório gerencial sobre a Cia Aérea. }\end{array}$ & Informal \\
\hline $\begin{array}{c}\text { Existe uma prática } \\
\text { de reuniões } \\
\text { operacionais padrão } \\
\text { entre fornecedor e } \\
\text { cliente? }\end{array}$ & $\begin{array}{l}\text { Não, não são feitas reuniões com datas pré determinadas, somente } \\
\text { reuniões comerciais }\end{array}$ & Informal \\
\hline $\begin{array}{l}\text { Existem regras } \\
\text { padronizadas com } \\
\text { relação aos riscos de } \\
\text { carga de alto valor? }\end{array}$ & Não foi mostrada nenhuma evidência desse controle. & Desconsiderado \\
\hline \multirow[t]{2}{*}{$\begin{array}{l}\text { Contexto (aplicado a } \\
\text { todas as dimensões) }\end{array}$} & Regras da Anvisa são fracas nos aeroportos & Informal \\
\hline & \multicolumn{2}{|c|}{$\begin{array}{l}\text { Como os fornecedores da Air Cargo não foram entrevistados, não poderemos fazer um } \\
\text { cruzamento de dados, mas há indícios de alta informalidade nas atividades da da Air Cargo com } \\
\text { a fornecedores. }\end{array}$} \\
\hline
\end{tabular}




\subsubsection{Formalização entre Eurochain e Sul Deste Cargo}

\begin{tabular}{|c|c|c|c|c|c|c|}
\hline \multirow[b]{3}{*}{ Critérios } & \multicolumn{4}{|c|}{ Formalização entre Eurochain e Sul Deste Cargo } & & \\
\hline & \multicolumn{2}{|c|}{ Pelo lado da Eurochain (Intra-analise) } & \multicolumn{2}{|c|}{$\begin{array}{l}\text { Pelo lado da Sul Deste } \\
\text { Cargo (Intra-analise) }\end{array}$} & \multirow{2}{*}{\multicolumn{2}{|c|}{ Resultado final }} \\
\hline & Análise & $\begin{array}{c}\text { Resulta- } \\
\text { do }\end{array}$ & Análise & $\begin{array}{c}\text { Resul } \\
\text { tado }\end{array}$ & & \\
\hline $\begin{array}{l}\text { Preços definidos e } \\
\text { formalizados? }\end{array}$ & $\begin{array}{l}\text { As tabelas preços não foram mostradas, o } \\
\text { entrevistado não quis mostrar. }\end{array}$ & $\begin{array}{l}\text { Descons } \\
\text { iderado }\end{array}$ & Preços formalizados. & $\begin{array}{l}\text { For- } \\
\text { mal }\end{array}$ & $\begin{array}{l}\text { Preços formalizados, a Eurochain não } \\
\text { mostrou, mas o transportador tinha. }\end{array}$ & Formal \\
\hline $\begin{array}{c}\text { Níveis de serviços estão } \\
\text { acordados e } \\
\text { formalizados? } \\
\end{array}$ & As tabelas de prazos foram evidenciadas & Formal & $\begin{array}{l}\text { Níveis formalizados } \\
\text { nos controles }\end{array}$ & $\begin{array}{l}\text { For- } \\
\text { mal }\end{array}$ & Níveis formalizados nos controles & Formal \\
\hline $\begin{array}{l}\text { Acompanhamento do } \\
\text { nível de serviço? }\end{array}$ & $\begin{array}{l}\text { Ata de acompanhamento de problemas } \\
\text { operacionais }\end{array}$ & Formal & $\begin{array}{l}\text { Atas com controles do } \\
\text { nível de serviço. }\end{array}$ & $\begin{array}{l}\text { For- } \\
\text { mal }\end{array}$ & $\begin{array}{l}\text { Atas com controles do nível de } \\
\text { serviço. }\end{array}$ & Formal \\
\hline $\begin{array}{l}\text { Existe uma prática de } \\
\text { reuniões operacionais } \\
\text { padrão entre } \\
\text { fornecedor e cliente? }\end{array}$ & $\begin{array}{l}\text { As atas de reuniões deixam bem claro as } \\
\text { metas para os fornecedores. }\end{array}$ & Formal & $\begin{array}{l}\text { Atas com controles do } \\
\text { nível de serviço. }\end{array}$ & $\begin{array}{l}\text { For- } \\
\text { mal }\end{array}$ & $\begin{array}{l}\text { Atas com controles do nível de } \\
\text { serviço. }\end{array}$ & Formal \\
\hline $\begin{array}{l}\text { Existem regras } \\
\text { padronizadas com } \\
\text { relação aos riscos de } \\
\text { carga de alto valor? }\end{array}$ & $\begin{array}{l}\text { A Eurochain com certeza possui as regras } \\
\text { de gerenciamento de risco, porém para } \\
\text { checar esse item do fornecedor, somente } \\
\text { na entrevista do fornecedor. }\end{array}$ & $\begin{array}{l}\text { Descons } \\
\text { iderado }\end{array}$ & $\begin{array}{l}\text { Plano de } \\
\text { Gerenciamento de } \\
\text { Risco e sistema com } \\
\text { regras formalizadas. }\end{array}$ & $\begin{array}{l}\text { For- } \\
\text { mal }\end{array}$ & $\begin{array}{l}\text { Plano de Gerenciamento de Risco e } \\
\text { sistema com regras formalizadas. }\end{array}$ & Formal \\
\hline $\begin{array}{l}\text { Contexto (aplicado a } \\
\text { todas as dimensões) }\end{array}$ & $\begin{array}{l}\text { De acordo com ao alto risco deste } \\
\text { transporte, e um processo rigoroso de } \\
\text { seleção de fornecedores, é coerente que } \\
\text { haja um acompanhamento formal da } \\
\text { operação. }\end{array}$ & Formal & $\begin{array}{l}\text { Apresentaram outros } \\
\text { controles que mostram } \\
\text { padronização nos } \\
\text { procedimentos }\end{array}$ & $\begin{array}{l}\text { For- } \\
\text { mal }\end{array}$ & $\begin{array}{l}\text { De acordo com ao alto risco deste } \\
\text { transporte, e um processo rigoroso de } \\
\text { seleção de fornecedores, é coerente } \\
\text { que haja um acompanhamento formal } \\
\text { da operação. }\end{array}$ & $\begin{array}{l}\text { Alta } \\
\text { Formali- } \\
\text { zação }\end{array}$ \\
\hline
\end{tabular}




\section{4 critérios são formalizados entre Eurochain e Sul Deste Cargo}

Resultado Final: 6 itens

demonstram que a Sul Deste

Cargo é fortemente Formalizada
Resultado Final: 6 itens demonstram que a Sul Deste Cargo é fortemente Formalizada

\subsubsection{Formalização entre Sul Deste Cargo e Transportadores Rodoviários}

\begin{tabular}{|c|l|c|}
\cline { 2 - 4 } \multicolumn{1}{c|}{} & \multicolumn{2}{c|}{ Formalização entre Sul Deste Cargo e Transportadores Rodoviários } \\
\cline { 2 - 4 } \multicolumn{1}{c|}{ Critérios } & \multicolumn{1}{c|}{ Análise } & \multicolumn{1}{c|}{ Resultado } \\
\hline $\begin{array}{c}\text { Preços definidos e } \\
\text { formalizados? }\end{array}$ & $\begin{array}{l}\text { Não sei se a tabela não foi mostrada porque não havia ou por sigilo de informação. } \\
\text { Embora a tabela não tivesse sido mostrada, foi apresentado o contrato com o fornecedor, } \\
\text { geralmente o primeiro ponto a ser assinado são os preços e por último os contratos, logo é } \\
\text { muito provável que exista a tabela de preços acordada. Entretanto como não foi visualizada } \\
\text { essa dimensão não será considerada. }\end{array}$ & Desconsiderado \\
\hline $\begin{array}{c}\text { Níveis de serviços } \\
\text { estão acordados e } \\
\text { formalizados? }\end{array}$ & $\begin{array}{l}\text { A Sul Deste Cargo sabe de sua meta de 98\%, pois foram evidenciadas nas apresentações } \\
\text { de performance. Existe um controle de performance do fornecedor e reuniões, porém em } \\
\text { nenhum documento foi observado explicitamente a meta do nível de serviço de } 98 \% \text { para } \\
\text { o fornecedor. }\end{array}$ & Informal \\
\hline $\begin{array}{c}\text { Acompanhamento } \\
\text { do nível de serviço? }\end{array}$ & $\begin{array}{l}\text { O controle interno foi verificado, o entrevista apresentou o arquivo excel, porém este não } \\
\text { detalhava o transportador, mas sim toda a filial }\end{array}$ & Informal \\
\hline $\begin{array}{c}\text { Existe uma prática } \\
\text { de reuniões } \\
\text { operacionais padrão } \\
\text { entre fornecedor e } \\
\text { cliente? }\end{array}$ & $\begin{array}{l}\text { Eram feitas reuniões, mas não haviam atas. } \\
\text { Em geral o controle de agregados é menos rigoroso que o controle de empresas. Entretanto } \\
\text { foi mostrado documentos que controlavam problemas operacionais de agregados, logo é } \\
\text { muito possível que existam controles só quando existam problemas. Mas por enquanto é } \\
\text { informal. }\end{array}$ & Informal \\
\hline
\end{tabular}


Existem regras

padronizadas com relação aos riscos de carga de alto valor?

Contexto (aplicado a todas as dimensões)
Foram vistas as regras. Os transportadores não serão entrevistados, mas será considerado formal.

A Sul Deste Cargo possui diversos controles e um sistema robusto para regras de gerenciamento de risco. Eles só possuem um fornecedor em São Paulo que foi o alvo da pesquisa, e este estão com eles há 6 meses. Neste caso embora alguns controles não tenha sido evidenciados, os outros controles e o curto período de tempo, justificam que seja classificado como formal neste critério.

3 critérios considerados informais, 2critério considerado formal. Análise final, levemente informal, apesar disso o ponto crítico que são as regras de risco, estas estão formalizadas.

\subsubsection{Integração Cialab - Eurochain}

\begin{tabular}{|c|c|c|c|c|c|c|}
\hline \multirow[b]{3}{*}{ Critérios } & \multicolumn{4}{|c|}{ Integração Cialab - Eurochain } & & \\
\hline & \multicolumn{2}{|c|}{ Versão Cialab (Intra-analise) } & \multicolumn{2}{|c|}{ Versão Eurochain (Intra-analise) } & \multirow{2}{*}{\multicolumn{2}{|c|}{ Resultado final }} \\
\hline & Análise & Resultado & Análise & Resultado & & \\
\hline $\begin{array}{l}\text { Iniciativas em } \\
\text { conjunto que } \\
\text { proporcionem } \\
\text { benefícios para } \\
\text { ambas as } \\
\text { empresas }\end{array}$ & $\begin{array}{l}\text { Empresas do setor trabalharam } \\
\text { em conjunto para não aceitar a } \\
\text { proposta do Sindusfarma, mas } \\
\text { não foi iniciativa colaborativa } \\
\text { entre agentes da cadeia }\end{array}$ & $\begin{array}{c}\text { Sem } \\
\text { Integra- } \\
\text { ção }\end{array}$ & $\begin{array}{l}\text { Embora os entrevistados não } \\
\text { tenham citado iniciativas claras, } \\
\text { disseram que geram pequenas } \\
\text { melhorias para ambos os lados e } \\
\text { se cria um benchmarking, o que é } \\
\text { identificado na literatura como } \\
\text { um grau de colaboração. }\end{array}$ & Integração & $\begin{array}{l}\text { Embora só a } \\
\text { Eurochain tenha } \\
\text { falado, a Cialab } \\
\text { comentou sobre a } \\
\text { mesma crise que deu } \\
\text { origem ao trabalho em } \\
\text { conjunto }\end{array}$ & Integração \\
\hline
\end{tabular}




\begin{tabular}{|c|c|c|c|c|c|c|}
\hline $\begin{array}{l}\text { Contexto } \\
\text { (aplicado a todas } \\
\text { as dimensões) }\end{array}$ & $\begin{array}{l}\text { Um histórico de relacionamento } \\
\text { longo, porém com dificuldades } \\
\text { recentes }\end{array}$ & $\begin{array}{c}\text { Indiferen- } \\
\text { te }\end{array}$ & $\begin{array}{l}\text { Os entrevistados } 1 \text { e } 2 \text { que são da } \\
\text { área operacional enxergam a } \\
\text { necessidade da proximidade do } \\
\text { cliente, mas o entrevistado } 3 \\
\text { entende que o cliente trabalha } \\
\text { com mais distância. }\end{array}$ & Indiferente & Ambos de acordo & Indiferente \\
\hline *Comunicação & $\begin{array}{l}\text { A comunicação apresentada é } \\
\text { basicamente operacional }\end{array}$ & $\begin{array}{l}\text { Sem } \\
\text { Integra- } \\
\text { ção }\end{array}$ & $\begin{array}{l}\text { Os entrevistados } 1 \text { e } 2 \text { que são da } \\
\text { área operacional enxergam uma } \\
\text { comunicação aberta com a } \\
\text { Cialab. O Entrevistado } 3 \text { da área } \\
\text { desconfia que o cliente irá ouvir a } \\
\text { Eurochain e diz não haver um } \\
\text { diálogo através da cadeia. } \\
\end{array}$ & Indiferente & $\begin{array}{l}\text { A comunicação } \\
\text { apresentada é } \\
\text { basicamente } \\
\text { operacional }\end{array}$ & $\begin{array}{c}\text { Sem } \\
\text { Integração }\end{array}$ \\
\hline *Confiança & $\begin{array}{l}\text { Confiança não no } \\
\text { relacionamento, mas na } \\
\text { capacidade operacional do } \\
\text { cliente. }\end{array}$ & $\begin{array}{l}\text { Sem } \\
\text { Integra- } \\
\text { ção }\end{array}$ & $\begin{array}{l}\text { O entrevistado } 3 \text { não tem plena } \\
\text { confiança se serão ouvidos pela } \\
\text { indústria. }\end{array}$ & $\begin{array}{c}\text { Sem } \\
\text { Integração }\end{array}$ & $\begin{array}{l}\text { Não há confiança no } \\
\text { relacionamento }\end{array}$ & $\begin{array}{c}\text { Sem } \\
\text { Integração }\end{array}$ \\
\hline $\begin{array}{c}* \text { Tempo de } \\
\text { relacionamento }\end{array}$ & $\begin{array}{l}\text { Esta conta possui mais de } 10 \\
\text { anos, um relacionamento com } \\
\text { foco no longo prazo. }\end{array}$ & $\begin{array}{l}\text { Integra- } \\
\text { ção }\end{array}$ & $\begin{array}{l}\text { Um relacionamento de } 14 \text { anos } \\
\text { certamente é de longo prazo }\end{array}$ & Integração & Conta de longo prazo & Integração \\
\hline & \multicolumn{2}{|c|}{$\begin{array}{l}\text { Resultado Final: } 3 \text { itens demonstram } \\
\text { fortemente a falta de integração entre } \\
\text { Cialab e a Eurochain. }\end{array}$} & \multicolumn{2}{|c|}{$\begin{array}{l}\text { Resultado Final: } 2 \text { critério demonstra leve } \\
\text { integração entre Cialab e a Eurochain, as } \\
\text { entrevistas mostram uma divergência de } \\
\text { entendimento entre o time de compra e o time } \\
\text { operacional. }\end{array}$} & $\begin{array}{l}\text { Embora só a } \\
\text { Eurochain tenha } \\
\text { falado, a Cialab } \\
\text { comentou sobre a } \\
\text { mesma crise que deu } \\
\text { origem ao trabalho em } \\
\text { conjunto }\end{array}$ & $\begin{array}{c}\text { Baixa } \\
\text { Integração }\end{array}$ \\
\hline
\end{tabular}


5.10.3.2. Integração Eurochain - Air Cargo

\begin{tabular}{|c|c|c|c|c|c|c|}
\hline \multirow[b]{4}{*}{$\begin{array}{c}\text { Critérios } \\
\text { Iniciativas em } \\
\text { conjunto que } \\
\text { proporcionem } \\
\text { benefícios para } \\
\text { ambas as empresas }\end{array}$} & \multicolumn{4}{|c|}{ Integração Eurochain - Air Cargo } & & \\
\hline & \multicolumn{2}{|c|}{ Versão Eurochain (Intra-analise) } & \multicolumn{2}{|c|}{ Versão Air Cargo (Intra-analise) } & \multirow{2}{*}{\multicolumn{2}{|c|}{ Resultado final }} \\
\hline & Análise & Resultado & Análise & Resultado & & \\
\hline & $\begin{array}{l}\text { Nenhuma iniciativa de } \\
\text { integração identificada }\end{array}$ & $\begin{array}{c}\text { Sem } \\
\text { Integração }\end{array}$ & $\begin{array}{l}\text { Não existe colaboração, pelo } \\
\text { contrário, são impostas medidas } \\
\text { que impõe prejuízos para o lado } \\
\text { mais fraco. }\end{array}$ & Sem Integração & $\begin{array}{l}\text { Nenhuma iniciativa } \\
\text { de integração } \\
\text { identificada }\end{array}$ & $\begin{array}{l}\text { Sem } \\
\text { Integra- } \\
\text { ção }\end{array}$ \\
\hline $\begin{array}{l}\text { Contexto (aplicado a } \\
\text { todas as dimensões) }\end{array}$ & $\begin{array}{l}\text { Existe um pensamento de } \\
\text { desenvolver fornecedores, } \\
\text { transferência de know-how. }\end{array}$ & Integração & $\begin{array}{l}\text { A Eurochain considera a Air } \\
\text { Cargo uma empresa importante }\end{array}$ & $\begin{array}{l}\text { Equilíbrio (sem } \\
\text { influência) }\end{array}$ & $\begin{array}{l}\text { Existe um } \\
\text { pensamento de } \\
\text { desenvolver } \\
\text { fornecedores, } \\
\text { transferência de } \\
\text { know-how. } \\
\text { Valorização da Air } \\
\text { Cargo } \\
\end{array}$ & $\begin{array}{l}\text { Integra- } \\
\text { ção }\end{array}$ \\
\hline *Comunicação & $\begin{array}{l}\text { Nenhuma iniciativa de } \\
\text { integração identificada }\end{array}$ & $\begin{array}{c}\text { Sem } \\
\text { Integração }\end{array}$ & $\begin{array}{l}\text { Transparência da parte da } \\
\text { AirCargo, abdicando de ganhos } \\
\text { maiores para auxiliar o cliente. }\end{array}$ & Integração & $\begin{array}{l}\text { Comunicação } \\
\text { transparente } \\
\text { unilateral }\end{array}$ & $\begin{array}{c}\text { Sem } \\
\text { Integra- } \\
\text { ção }\end{array}$ \\
\hline *Confiança & $\begin{array}{l}\text { O entrevistado } 3 \text { entende a } \\
\text { necessidade da confiança no } \\
\text { relacionamento, entretanto } \\
\text { não existem evidências de } \\
\text { confiança na relação. }\end{array}$ & $\begin{array}{c}\text { Sem } \\
\text { Integração }\end{array}$ & $\begin{array}{l}\text { Apesar da Air Cargo dizer que } \\
\text { possui bom relacionamento eles } \\
\text { não possuem a confiança da } \\
\text { Eurochain que não os permite } \\
\text { nem falar com os seus clientes. } \\
\text { A Eurochain também sem } \\
\text { avisar a Air Cargo tentou cotar } \\
\text { preços diretos com a Cia Aérea }\end{array}$ & Sem Integração & Ambos de Acordo & $\begin{array}{c}\text { Sem } \\
\text { Integra- } \\
\text { ção }\end{array}$ \\
\hline
\end{tabular}




\begin{tabular}{|c|c|c|c|c|c|c|}
\hline $\begin{array}{c}* \text { Tempo de } \\
\text { relacionamento }\end{array}$ & $\begin{array}{l}\text { Os entrevistados concordam } \\
\text { que os transportadores } \\
\text { possuem um tempo médio de } \\
\text { relacionamento } 5 \text { anos. }\end{array}$ & $\begin{array}{l}\text { Indiferent } \\
\mathrm{e}\end{array}$ & Pouco tempo de relacionamento & Sem integração & $\begin{array}{l}\text { Pouco tempo de } \\
\text { relacionamento }\end{array}$ & $\begin{array}{c}\text { Sem } \\
\text { Integra- } \\
\text { ção }\end{array}$ \\
\hline & \multicolumn{2}{|c|}{$\begin{array}{l}\text { Resultado Final: } 3 \text { critérios } \\
\text { demonstram fortemente a falta de } \\
\text { integração entre Air Cargo e a } \\
\text { Eurochain. }\end{array}$} & \multicolumn{2}{|c|}{$\begin{array}{c}3 \text { critérios apontam para não integração, } 1 \text { para } \\
\text { integração. Resultado final: Forte falta de } \\
\text { integração }\end{array}$} & $\begin{array}{l}\text { Apesar de haver um } \\
\text { esforço no } \\
\text { desenvolvimento de } \\
\text { fornecedores, todos } \\
\text { os outros } 4 \text { critérios } \\
\text { apontam falta de } \\
\text { integração }\end{array}$ & $\begin{array}{l}\text { Grande } \\
\text { Falta de } \\
\text { Integraçã } \\
\text { o }\end{array}$ \\
\hline
\end{tabular}


5.10.3.3. Integração Air Cargo - Cia Aéreas

\begin{tabular}{|c|c|c|}
\hline & \multicolumn{2}{|l|}{ Integração Air Cargo - Cia Aéreas } \\
\hline & \multicolumn{2}{|l|}{ Versão da Air Cargo } \\
\hline Critérios & Análise & Resultado \\
\hline $\begin{array}{c}\text { Iniciativas em } \\
\text { conjunto que } \\
\text { proporcionem } \\
\text { benefícios para } \\
\text { ambas as empresas } \\
\end{array}$ & $\begin{array}{l}\text { O trecho da conversa ao lado foi em geral, mas nenhuma outra evidência } \\
\text { foi mostrada. }\end{array}$ & Sem Integração \\
\hline $\begin{array}{l}\text { Contexto (aplicado a } \\
\text { todas as dimensões) }\end{array}$ & São clientes considerados importantes e são atendidos de forma especial & Integração \\
\hline *Comunicação & $\begin{array}{l}\text { Além do atendimento especial, existe uma confiança que proporcionou a } \\
\text { informação de que seu cliente Eurochain estava tentando ir diretamente a } \\
\text { seus fornecedores. }\end{array}$ & Integração \\
\hline *Confiança & $\begin{array}{l}\text { Houve confiança por parte da Cia Aérea para contar informações } \\
\text { sigilosas para a Air cargo }\end{array}$ & Integração \\
\hline \multirow[t]{2}{*}{$\begin{array}{c}* \text { Tempo de } \\
\text { relacionamento }\end{array}$} & $\begin{array}{l}\text { (sem evidências: disseram que há poucos anos surgiram novas empresas } \\
\text { para se trabalhar) }\end{array}$ & Desconsiderar \\
\hline & \multicolumn{2}{|c|}{$\begin{array}{l}\text { Embora não exista uma iniciativa de integração como demonstra a literatura, neste } \\
\text { relacionamento parece existir confiança e comunicação que possa ser um campo fértil para uma } \\
\text { futura iniciativa. De } 4 \text { itens } 3 \text { são a favor da integração. Baixa Integração }\end{array}$} \\
\hline
\end{tabular}


5.10.3.4. Integração Eurochain - Sul Deste Cargo 


\begin{tabular}{|c|c|c|c|c|c|c|}
\hline & \multicolumn{4}{|c|}{ Integração Eurochain - Sul Deste Cargo } & & \\
\hline & \multicolumn{2}{|c|}{ Versão Eurochain (Intra-analise) } & \multicolumn{2}{|c|}{ Versão Sul Deste Cargo (Intra-analise) } & \multirow{2}{*}{\multicolumn{2}{|c|}{ Resultado final }} \\
\hline Critérios & Análise & Resultado & Análise & Resultado & & \\
\hline $\begin{array}{l}\text { Iniciativas em } \\
\text { conjunto que } \\
\text { proporcionem } \\
\text { benefícios para } \\
\text { ambas as } \\
\text { empresas } \\
\end{array}$ & $\begin{array}{l}\text { Nenhuma iniciativa de } \\
\text { integração identificada }\end{array}$ & $\begin{array}{c}\text { Sem } \\
\text { Integração }\end{array}$ & (Sem Evidências) & Sem Integração & $\begin{array}{l}\text { Nenhuma iniciativa de } \\
\text { integração identificada }\end{array}$ & $\begin{array}{c}\text { Sem } \\
\text { Integração }\end{array}$ \\
\hline $\begin{array}{l}\text { Contexto } \\
\text { (aplicado a todas } \\
\text { as dimensões) }\end{array}$ & $\begin{array}{l}\text { Existe um pensamento de } \\
\text { desenvolver fornecedores, } \\
\text { transferência de know-how. }\end{array}$ & Integração & $\begin{array}{l}\text { Não houve nenhuma } \\
\text { informação relevante que } \\
\text { não foi discutida em } \\
\text { outros critérios. } \\
\text { Desconsiderar } \\
\end{array}$ & $\begin{array}{l}\text { Desconsiderad } \\
\text { o }\end{array}$ & $\begin{array}{l}\text { Neste caso só a vontade de } \\
\text { desenvolver, sem nenhuma } \\
\text { valorização da Sul Deste Cargo, } \\
\text { não é indício para integração }\end{array}$ & $\begin{array}{c}\text { Sem } \\
\text { Integração }\end{array}$ \\
\hline *Comunicação & $\begin{array}{l}\text { Nenhuma iniciativa de } \\
\text { integração identificada }\end{array}$ & $\begin{array}{c}\text { Sem } \\
\text { Integração }\end{array}$ & $\begin{array}{l}\text { Os dados operacionais } \\
\text { para planejamento são } \\
\text { bons, entretanto a } \\
\text { desorganização interna } \\
\text { dos times prejudica a } \\
\text { comunicação. }\end{array}$ & Sem Integração & Ambos de Acordo & $\begin{array}{c}\text { Sem } \\
\text { Integração }\end{array}$ \\
\hline *Confiança & $\begin{array}{l}\text { O entrevistado } 3 \text { entende a } \\
\text { necessidade da confiança no } \\
\text { relacionamento, entretanto não } \\
\text { existem evidências de } \\
\text { confiança na relação. }\end{array}$ & $\begin{array}{c}\text { Sem } \\
\text { Integração }\end{array}$ & $\begin{array}{l}\text { Falta de confiança, a } \\
\text { Eurochain enxerga a Sul } \\
\text { Deste Cargo como } \\
\text { possível competidor }\end{array}$ & Sem Integração & & $\begin{array}{c}\text { Sem } \\
\text { Integração }\end{array}$ \\
\hline \multirow[t]{2}{*}{$\begin{array}{l}* \text { Tempo de } \\
\text { relacionamento }\end{array}$} & $\begin{array}{l}\text { Os entrevistados concordam } \\
\text { que os transportadores } \\
\text { possuem um tempo médio de } \\
\text { relacionamento } 5 \text { anos. }\end{array}$ & Indiferente & $\begin{array}{l}\text { Relacionamento de } \\
\text { longo prazo }\end{array}$ & Integração & Relacionamento de longo prazo & Integração \\
\hline & \multicolumn{2}{|c|}{$\begin{array}{l}\text { Resultado Final: } 3 \text { critérios demonstram } \\
\text { grande a falta de integração entre Sul Deste } \\
\text { Cargo e a Eurochain. }\end{array}$} & \multicolumn{2}{|c|}{$\begin{array}{c}\text { Resultado Final: } 3 \text { itens demonstram } \\
\text { fortemente a falta de integração entre Sul } \\
\text { Deste Cargo e a Eurochain . }\end{array}$} & $\begin{array}{l}\text { Só o longo prazo de } \\
\text { relacionamento não é suficiente } \\
\text { contra os outros } 4 \text { critérios que } \\
\text { apontam falta de integração }\end{array}$ & $\begin{array}{l}\text { Grande } \\
\text { Falta de } \\
\text { Integração }\end{array}$ \\
\hline
\end{tabular}


5.10.4.1. Integração Sul Deste Cargo - Transportadores Rodoviários

\begin{tabular}{|c|c|c|}
\hline & \multicolumn{2}{|l|}{ Integração Sul Deste Cargo - Transportadores Rodoviários } \\
\hline & \multicolumn{2}{|c|}{ Versão da Sul Deste Cargo } \\
\hline Critérios & Análise & Resultado \\
\hline $\begin{array}{c}\text { Iniciativas em } \\
\text { conjunto que } \\
\text { proporcionem } \\
\text { benefícios para } \\
\text { ambas as empresas } \\
\end{array}$ & $\begin{array}{l}\text { Apesar de já terem ocorrido iniciativas colaborativas, nenhuma dessas } \\
\text { empresas era da cadeia. }\end{array}$ & Sem Integração \\
\hline $\begin{array}{l}\text { Contexto (aplicado a } \\
\text { todas as dimensões) }\end{array}$ & $\begin{array}{l}\text { Não houve nenhuma informação relevante que não foi discutida em } \\
\text { outros critérios. Desconsiderar }\end{array}$ & Desconsiderado \\
\hline *Comunicação & Reuniões puramente operacionais, pouco histórico de relacionamento & Sem Integração \\
\hline *Confiança & $\begin{array}{l}\text { Não houve nenhuma informação relevante que não foi discutida em } \\
\text { outros critérios. Desconsiderar }\end{array}$ & Desconsiderado \\
\hline \multirow[t]{2}{*}{$\begin{array}{l}* \text { Tempo de } \\
\text { relacionamento }\end{array}$} & $\begin{array}{l}\text { Antigamente não havia subcontratação em São Paulo, por isso como esta } \\
\text { operação é muito nova, não deve ser levada em consideração. }\end{array}$ & Desconsiderado \\
\hline & \multicolumn{2}{|c|}{$\begin{array}{c}\text { Resultado Final: } 2 \text { itens demonstram grande a falta de integração entre Sul Deste Cargo e a } \\
\text { seus fornecedores. }\end{array}$} \\
\hline
\end{tabular}


5.10.4.2. Integração Air Cargo - Transportadores Rodoviários

\begin{tabular}{|c|c|c|}
\hline & \multicolumn{2}{|l|}{ Integração Air Cargo - Transportadores Rodoviários } \\
\hline & \multicolumn{2}{|l|}{ Versão da Air Cargo } \\
\hline Critérios & Análise & Resultado \\
\hline $\begin{array}{c}\text { Iniciativas em } \\
\text { conjunto que } \\
\text { proporcionem } \\
\text { benefícios para } \\
\text { ambas as empresas } \\
\end{array}$ & $\begin{array}{l}\text { O trecho da conversa ao lado foi em geral, mas nenhuma outra evidência } \\
\text { foi mostrada. }\end{array}$ & Sem Integração \\
\hline $\begin{array}{l}\text { Contexto (aplicado a } \\
\text { todas as dimensões) }\end{array}$ & $\begin{array}{l}\text { A princípio existe uma preocupação com o desenvolvimento dos } \\
\text { parceiros }\end{array}$ & Integração \\
\hline *Comunicaçãa & Comunicação meramente operacional & Sem Integração \\
\hline *Confiança & $\begin{array}{l}\text { Com relação ao mercado depende, existem concorrentes que colaboram e } \\
\text { outros desleais. Como nenhum dos casos diz respeito a uma empresa da } \\
\text { cadeia, então desconsiderar este critério. }\end{array}$ & Desconsiderado \\
\hline \multirow[t]{2}{*}{$\begin{array}{c}* \text { Tempo de } \\
\text { relacionamento }\end{array}$} & Médio prazo & Indiferente \\
\hline & \multicolumn{2}{|c|}{$\begin{array}{c}2 \text { critérios apontam a falta de integração, } 1 \text { critério aponta a integração, resultado, Baixa falta } \\
\text { integração. }\end{array}$} \\
\hline
\end{tabular}




\subsubsection{Destaque sobre Poder do Destinatário Final}

Todos os agentes entendem o cliente da Cialab como centralizador de poder.

\begin{tabular}{|c|c|c|c|}
\hline Air Cargo & ul Deste Cargo & Eurochain & Cialab \\
\hline $\begin{array}{lr}\text { A } & \text { percepção } \\
\text { do } & \text { cliente } \\
\text { (distribuidores) } \\
\text { da } & \text { Cialab } \\
\text { sobre } & \text { a } \\
\text { performance } & \text { é } \\
\text { muito } & \\
\text { importante. }\end{array}$ & \begin{tabular}{|lrr} 
O & poder & dos \\
distribuidores & é \\
muito & grande, \\
eles & são & os \\
grandes & clientes \\
dos laboratórios, \\
assim & & o \\
laboratório & \\
nunca & & quer \\
entrar & & em \\
conflito & com & os \\
seus & clientes, \\
dessa & forma \\
quando & temos \\
problemas & \\
estoura & para & o \\
lado & & da \\
Eurochain e & para \\
o lado & da & Sul \\
Deste & Cargo. &
\end{tabular} & $\begin{array}{l}\text { Se o cliente não estiver próximo ele não vai entender a operação, não } \\
\text { vai conseguir ajudar e não vai estar satisfeito. Já perdemos clientes } \\
\text { que estávamos com um nível de serviço excelente, mas ele } \\
\text { enxergava uma qualidade baixíssima por não estar perto da operação, } \\
\text { não compreendia que os verdadeiros problemas não estavam na } \\
\text { nossa operação. A força de vendas da indústria sempre tentará } \\
\text { colocar a culpa de baixas vendas na logística. Mas não adianta } \\
\text { terceirizar se deixar largado é extremamente necessária a } \\
\text { participação intensa do cliente. Não arrumamos sozinha a operação. } \\
\text { Muitos acreditam que pelo nosso renome conseguimos solucionar } \\
\text { todos os problemas, assim não querem ter envolvimento algum. } \\
\text { (Entrevistados } \\
\text { O distribuidor, cliente da indústria, tem muita força, a opinião dele é } \\
\text { a que vai pesar para a indústria. Um cliente me disse que os } \\
\text { indicadores não têm importância para ele e sim o que o cliente final } \\
\text { dele está pensando. (Entrevistados } 1 \\
\text { O distribuidor é o elo forte da cadeia, ele decide se a carga pode ser } \\
\text { misturada ou não, ele decide se retém o comprovante ou não, isso } \\
\text { não é correto, o certo é que todos os comprovantes sejam entregues } \\
\text { no ato, mas alguns distribuidores não devolvem assim o } \\
\text { transportador e nós não temos como comprovar que a carga foi } \\
\text { entregue, mas não conseguimos mudar isso. Melhoramos algumas } \\
\text { dificuldades como o alinhamento dos prazos, o prazo que o cliente } \\
\text { entendia era diferente do nosso. (Eles explicaram que em alguns } \\
\text { casos o cliente começava a contar o prazo de entrega a partir do } \\
\text { momento que fechava a negociação, mas não considerava outros }\end{array}$ & $\begin{array}{l}\text { Alguns pontos de venda colocam tantas } \\
\text { complicações operacionais que o custo logístico } \\
\text { não compensa a negociação comercial, assim } \\
\text { optamos por não ficar neste ponto de venda. } \\
\text { Os distribuidores (clientes da Cialab) são muito } \\
\text { fortes comercialmente, às vezes algum problema } \\
\text { operacional nosso, para eles não é de todo ruim, } \\
\text { pois pode servir como "moeda" de negociação, } \\
\text { assim se temos algum problema na entrega isso } \\
\text { pode gerar um pedido de prorrogação de } \\
\text { pagamento por parte dos distribuidores. O } \\
\text { distribuidor impõe condições para receber a carga } \\
\text { que aumentam os nossos custos para que eles } \\
\text { possam ter menos trabalho na conferência e } \\
\text { recebimento, mas o custo fica conosco. } \\
\text { Antigamente alguns destes distribuidores eram } \\
\text { empresas familiares, pouco profissionalizadas, } \\
\text { atualmente eles se profissionalizaram e estão mais } \\
\text { exigentes. Alguns foram comprados por } \\
\text { multinacionais. } \\
\text { Em alguns casos eles não devolvem o canhoto na } \\
\text { hora, pois devido a questões fiscais recebem a } \\
\text { mercadoria em um local, mas irão armazená-la em } \\
\text { outro, assim só recebem a carga, mas irão conferir } \\
\text { só no destino final, enquanto não conferem, não } \\
\text { devolvem o canhoto. }\end{array}$ \\
\hline
\end{tabular}


prazos como de sistema, aprovação do pedido, descontos, separação da carga e agendamentos) (Entrevistados 1 e 2) 


\subsection{Análise das Dimensões na Cadeia}

\subsubsection{Dimensão Centralização}

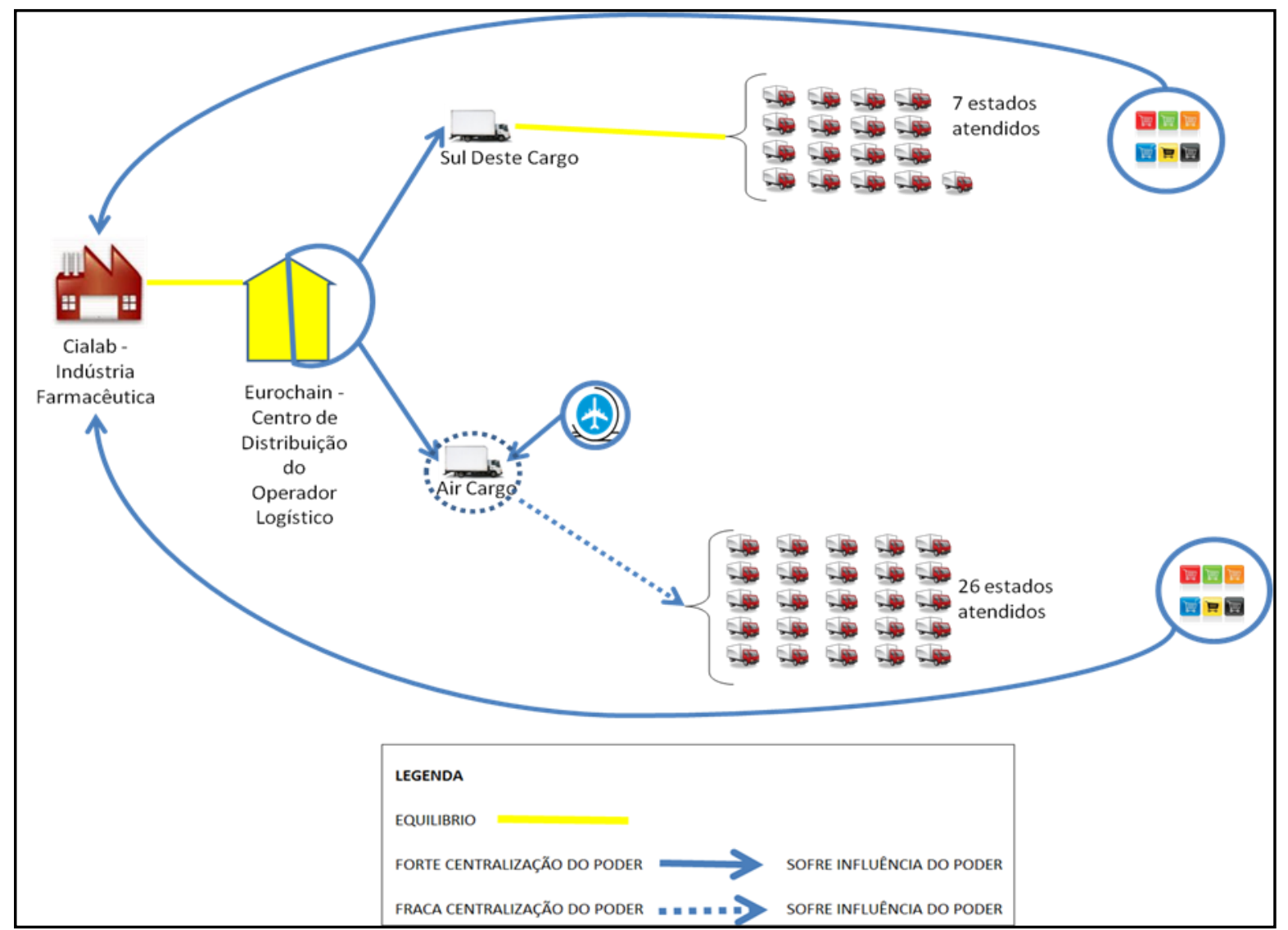

\section{Ilustração 18: Centralização na Cadeia}

Se, ao invés de analisar uma cadeia, fosse analisada uma organização, segundo a literatura, quanto mais próxima da alta gestão (mais próximo da hierarquia mais alta da empresa), mais forte seria a centralização (Kim, 2006). Entretanto, conforme é exemplificado na Ilustração 18 é possível verificar que a influência da companhia aérea é muito forte, mesmo sendo uma subcontratada de um terceiro do Operador logístico, ou seja, a três relacionamentos de distância da Indústria, que seria a alta gestão (hierarquia mais alta da empresa). Esse poder da companhia aérea, como já foi discutido nas análises inter-empresa, reside no fato de que a atividade principal dela não é o transporte de cargas, mas sim de pessoas; assim, nesta negociação, o cliente precisa mais dela do que ela dele.

Outro importante achado, que não foi previsto segundo a teoria, é o caso da forte influência dos clientes finais, pois, a princípio, eles não participam ativamente da gestão da cadeia. Entretanto, a atividade de recebimento que eles precisam executar pode impactar toda a cadeia, seja retendo os canhotos das Notas Fiscais - o que impossibilita as empresas de provarem que receberam a carga -, seja rejeitando a carga - pois ela não foi entregue no formato que facilite a operação deles. Essas atitudes do cliente dificultam a operação e aumentam os custos dos transportadores e do operador logístico. O baixo nível de integração entre as empresas da cadeia não permite uma discussão para se organizarem e terem 
representação suficiente para conseguirem negociar de igual para igual com uma agente de tanta força.

O operador logístico concentra grande poder devido ao seu volume de carga para os fornecedores e também apresenta uma relação de equilíbrio com a indústria, devido ao seu conhecimento específico do negócio. A indústria confia fortemente na capacidade técnica do operador logístico.

A força - tanto da Sul Deste Cargo quanto da Air Cargo - sobre seus fornecedores não é tão forte quanto do operador logístico sobre eles. Estes transportadores finais trabalham para outras empresas, assim diminuindo o poder de influência dos clientes.

Enfim, a dimensão Centralização não pode ser encontrada na cadeia, segundo a definição da literatura, pois não há concentração de poder em um agente da cadeia; este está dividido entre indústria, operador logístico, cliente final e companhia aérea. É importante ressaltar que não é o caso de uma descentralização planejada pela indústria, na qual esta forneceria intencionalmente autonomia para outros agentes, mas sim uma descentralização devida ao poder de cada agente que não está sob controle da indústria. 


\subsubsection{Dimensão Complexidade}

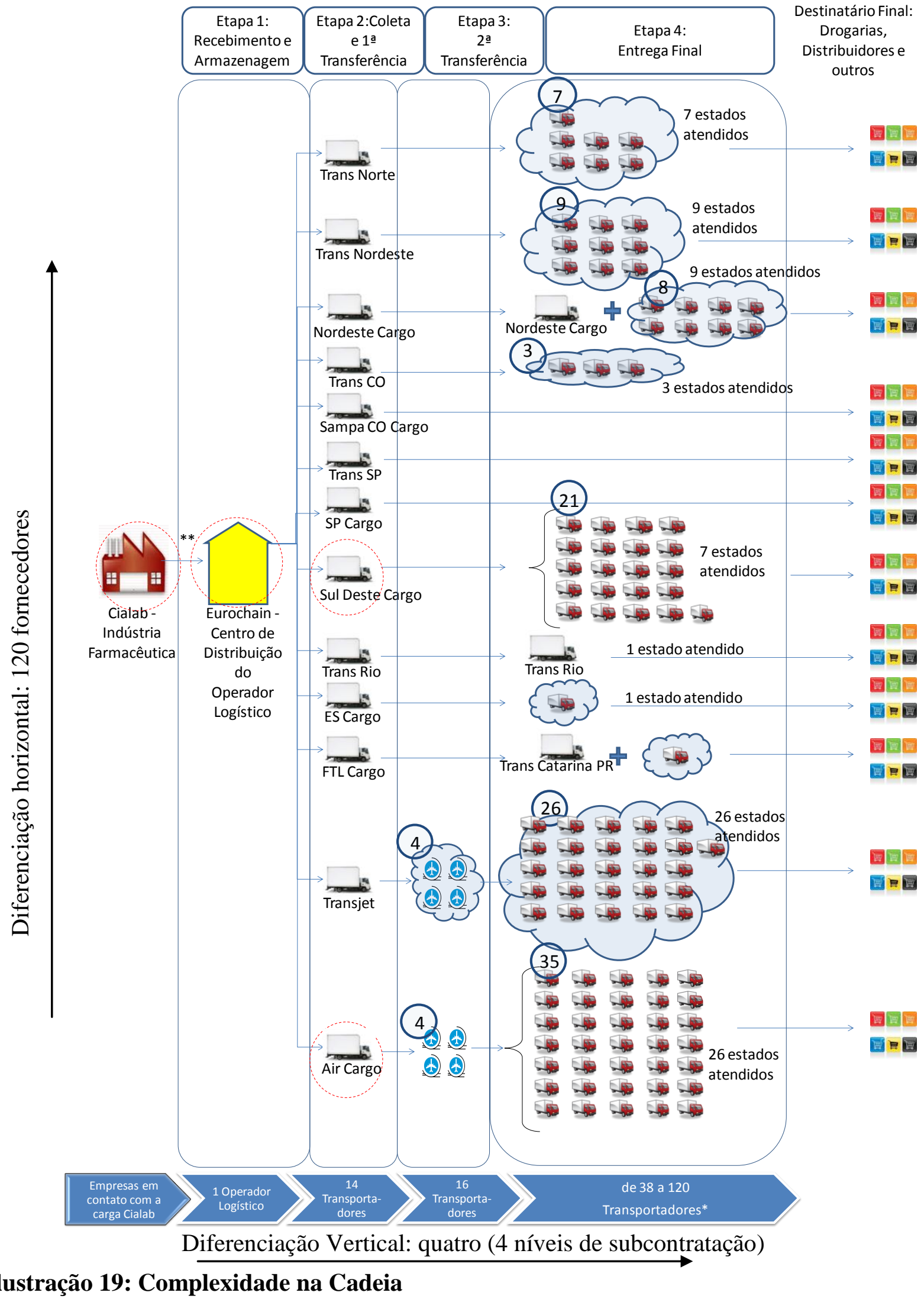


A seguir, se encontra o quadro legenda explicativo da figura acima:

\begin{tabular}{|c|c|}
\hline & $\begin{array}{l}\text { S caminhões brancos representam as empresas contratadas diretamente pelo } \\
\text { erador logístico. Todos os outros são contratados diretamente pelo } \\
\text { nsportador da Etapa anterior, com exceção das empresas Air Cargo e } \\
\text { ansjet, que contratam diretamente tanto a companhia aérea quanto os } \\
\text { nsportadores da Etapa 3. }\end{array}$ \\
\hline & $\begin{array}{l}\text { Este símbolo representa } \\
\text { spectivas empresas de tr }\end{array}$ \\
\hline & $\begin{array}{l}\text { - Os caminhões vermelhos representam as empresas contratadas diretamente } \\
\text { pelos transportadores da Etapa 2. As companhias aéreas não contratam } \\
\text { nenhuma empresa nesta cadeia. }\end{array}$ \\
\hline & $\begin{array}{l}\text { - Os veículos dentro de nuvem re } \\
\text { de transportes que atuam nesta } \\
\text { considerado que, na média, é cont } \\
\text { Os veículos sem nuvens represe } \\
\text { entrevistas, de diferentes empresa }\end{array}$ \\
\hline & s os outros nomes são f \\
\hline & $\begin{array}{l}\text { Cialab, Eurochain, Sul Deste Cargo e } \\
\text { das nesta pesquisa. }\end{array}$ \\
\hline \multicolumn{2}{|c|}{$\begin{array}{l}\text { * - "de } 38 \text { a } 120 \text { " é uma estimativa. } 38 \text { é o número mínimo de transportadores na Etapa } 4 \text { com } \\
\text { o qual seria possível atender todo o Brasil, considerando que todas as diferentes empresas de } \\
\text { transportes da Etapa } 2 \text { que atendem um estado em comum, contratem exatamente a mesma } \\
\text { empresa neste estado para a Etapa } 4 \text {. Temos } 38 \text {, ao invés de } 26 \text {, número de estados no Brasil, } \\
\text { pois nas entrevistas já foi demonstrado que o mínimo é de } 38 \text {. } 120 \text { é o número de } \\
\text { transportadores que haveria na Etapa } 4 \text {, caso as empresas de transportes da Etapa } 2 \text { que atuam } \\
\text { em um estado em comum contratassem diferentes empresas para a Etapa } 4 \text {. Esta estimativa } \\
\text { parte da premissa que, em média, cada empresa da Etapa } 2 \text { contrata uma empresa de } \\
\text { transporte para a Etapa } 4 \text { por estado. }\end{array}$} \\
\hline
\end{tabular}

\section{Ilustração 20: Legenda da Ilustração 19}

Segundo a definição de Robbins (1983), a Complexidade é o grau de diferenciação que existe dentro da organização e deve ser analisada em três variáveis:

- Diferenciação Horizontal.

- Diferenciação Vertical.

- Dispersão Espacial.

Outros autores ainda consideram a diferença entre os tipos de empresas que fazem parte da cadeia. Neste caso, conforme Ilustração 19, é possível verificar um perfil diferenciado entre as empresas de aéreo e rodoviário; as empresas do aéreo precisam de licenças e conhecimentos adicionais para execução de seu serviço e a forma de cobrança também difere o que implica em uma gestão diferenciada do operador logístico e da indústria para controlar a operação, aumentando ainda mais a complexidade. 
Como discutido anteriormente, não seria viável mapear todas as empresas presentes nesta cadeia, assim foi escolhida a cadeia que representa $80 \%$ de todo o volume de vendas da Cialab.

Não existe um padrão na literatura do que é considerado complexo ou não. Neste caso, podemos fazer algumas análises de cenários fictícios para entender melhor cada variável:

- Cenário Fictício 1 - Diferenciação Vertical: uma empresa com atuação somente em um município, com somente um modal e somente um fornecedor contratado diretamente (diferenciação horizontal 1), mas este fornecedor subcontrataria um fornecedor $\mathrm{B}$, que subcontrataria um fornecedor $\mathrm{C}$, que por sua vez contrataria um fornecedor $\mathrm{D}$. O cliente teria dificuldade para conseguir gerenciar o fornecedor $\mathrm{D}$, devido a sua distância, por isso, considerando o caso real em estudo, que possui diferenciação vertical quatro, isso representa uma cadeia complexa;

- Cenário Fictício 2 - Diferenciação Horizontal: uma empresa com atuação somente em um município, com somente um modal e cento e vinte fornecedores contratados diretamente sem subcontratações. Gerenciar cento e vinte fornecedores exige grande esforço deste único cliente implicando em cadeia complexa;

- Cenário Fictício 3 - Dispersão Geográfica: uma empresa com atuação em todo o Brasil, com somente um modal e somente um fornecedor. Conseguir manter os mesmo procedimentos e padrão de qualidade em todos os municípios atendidos exige grande esforço resultando em complexidade para a cadeia;

- Cenário Fictício 4 - Diferenciação entre fornecedores: uma empresa com atuação em somente um município, com dois modais (aéreo e rodoviário) e somente um fornecedor. Trabalhar com dois modais exige mais conhecimento e controles por parte do contratante.

Tabela 20: Resultado da análise da Complexidade

\begin{tabular}{|l|l|}
\hline Diferenciação Vertical quatro empresas & Complexo \\
\hline Diferenciação horizontal pode chegar até 120 empresas & Complexo \\
\hline Dispersão espacial todo o Brasil & Complexo \\
\hline Dois modais diferentes: aéreo e rodoviário & Complexo \\
\hline Resultado & Alta complexidade \\
\hline
\end{tabular}

Considerando a cadeia da Cialab, temos alta complexidade, pois esta é atendida por dois modais, em toda extensão territorial do Brasil, com quatro níveis de subcontratação de fornecedores e até cento e vinte fornecedores na etapa final da entrega. Ou seja, para que o operador logístico tenha controle sobre toda a operação, exigirá enorme número de controles e esforço. Por isso é compreensível a necessidade de um operador logístico, pois este faz o pesado trabalho de gerenciamento dos fornecedores, o qual a indústria terceiriza. 


\subsection{2 .3}

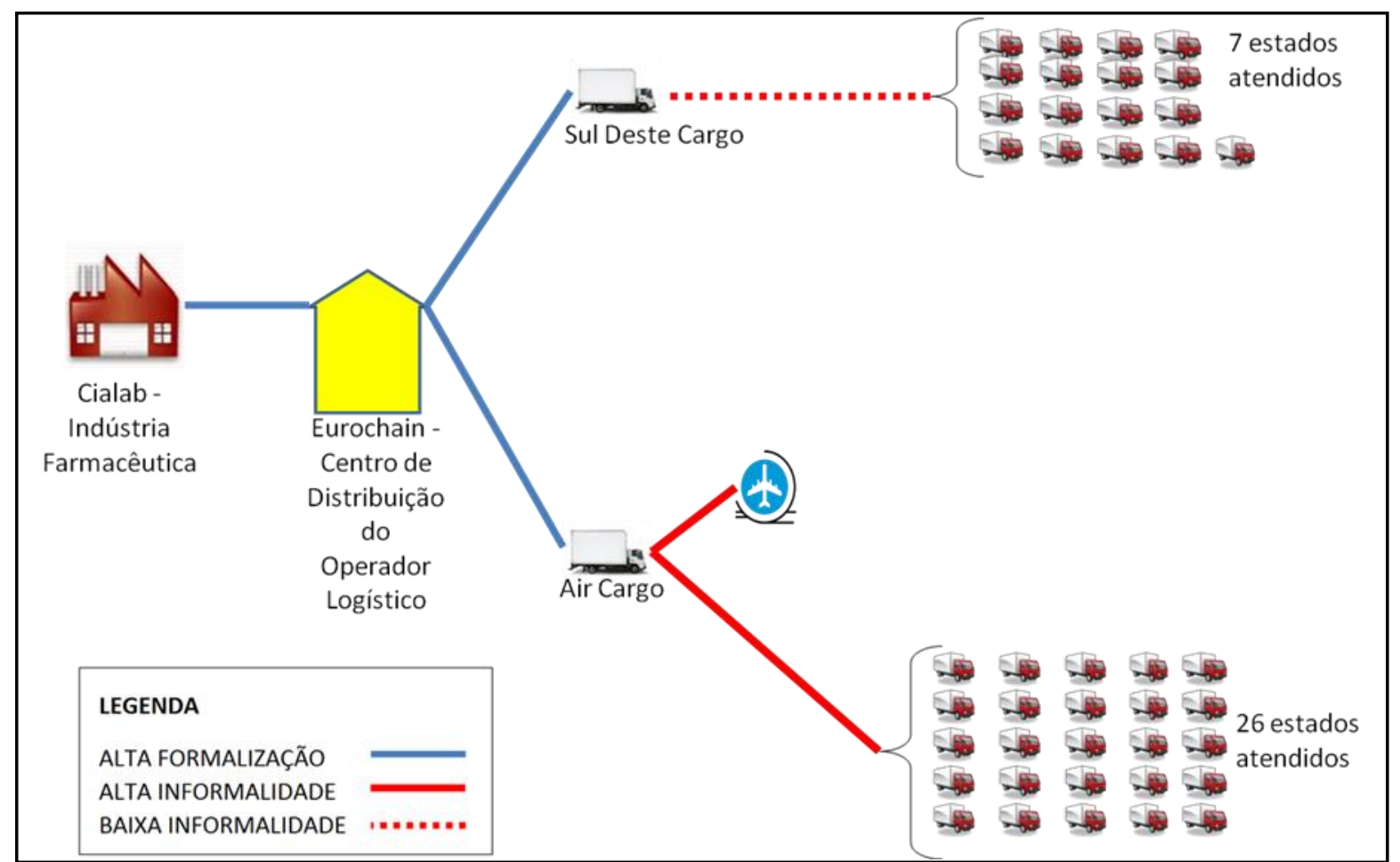

Ilustração 21: Formalização na Cadeia

Mesmo sendo uma cadeia de medicamentos com forte regulamentação da Anvisa, conforme apontado pelas entrevistas, o controle e formalização sobre os fornecedores na entrega final são baixos, conforme Ilustração 21 demonstra. Isso pode ser explicado pela dimensão Complexidade, pois as entregas são "pulverizadas" e o número de fornecedores cresce fortemente além da dispersão espacial em todos os estados do país.

A formalização entre indústria, operador logístico e seus fornecedores diretos é alta, baseada em contratos, tabelas de preço, relatórios de desempenho e reuniões formais. Nestes agentes, o controle da Anvisa se torna mais fácil, inclusive pelo menor número de empresas. Por outro lado, conforme um dos entrevistados, os aeroportos - e por consequência as companhias aéreas - não estão tão expostos a auditorias da Anvisa. 


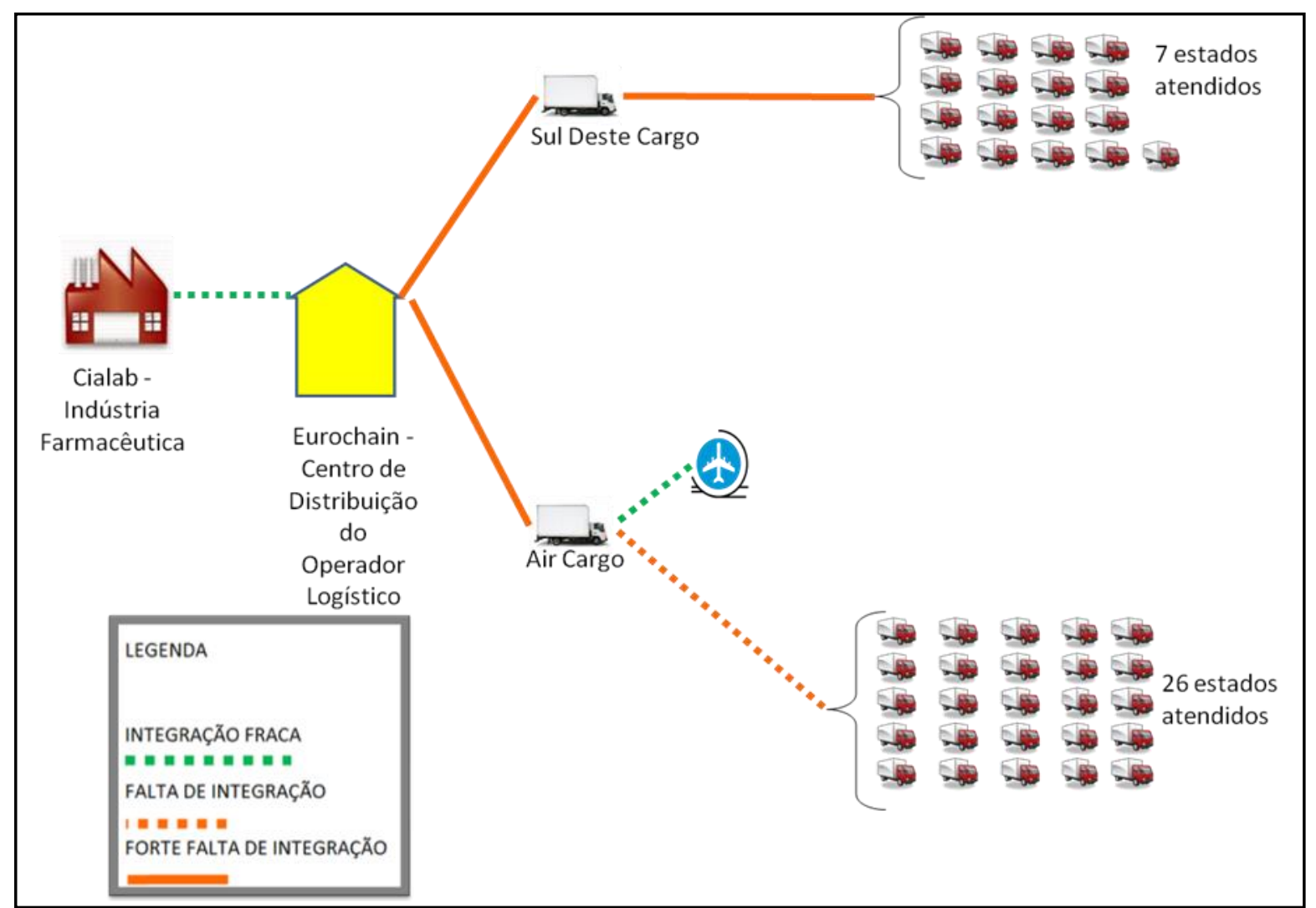

Ilustração 22: Integração na Cadeia

Não foi identificada nenhuma iniciativa clara de colaboração entre os agentes da cadeia. O relacionamento entre Operador Logístico e Cialab apresenta algum desenvolvimento de melhorias que causam ganhos para os dois lados, segundo entrevistados 1 e 2 do Operador Logísticos.

Entre o operador logístico e a Air Cargo e a Sul Deste Cargo, existe grande falta de integração e isso pode ser devido à falta de confiança, mesmo tendo relacionamentos de longo prazo. Este resultado é coerente com a negociação agressiva nos preços, conforme apontaram a Air Cargo e Sul Deste Cargo. Ambas empresas sofrem dificuldade para negociar preços com o operador logístico e são muito pressionadas para redução de custos.

Apesar da Air Cargo e a companhia aérea não apresentarem nenhuma evidência de colaboração efetiva entre as empresas, elas possuem um bom canal de comunicação, inclusive com evidência de confiança entre as partes, por isso foi identificado que não há integração, mas não é uma grande falta de integração.

Estas relações estão demonstradas na Ilustração 22. 


\section{CONCLUSÃO}

A Gestão da Cadeia de Suprimentos tem evoluído nas últimas décadas, passando por diferentes ênfases, primeiramente pela eficiência da produção, em um segundo momento, pelo aumento da competitividade através de parcerias e alianças em sua cadeia e, atualmente, busca expandir a cadeia, interagindo com novos agentes em novas redes (MILES e SNOW, 2007).

Para suportar esta evolução do conhecimento, pesquisadores desenvolveram novos modelos de análise, inclusive utilizando conhecimentos advindos de outras áreas, além da área de operações. Por exemplo, teoria dos grafos a qual se origina na matemática computacional (KIM et al, 2010). Ketchen e Hult (2007) destacam que teorias oriundas de áreas diversas do conhecimento podem enriquecer a pesquisa na Gestão da Cadeia de Suprimentos, criando novos caminhos e reflexões e, em especial, destacam as teorias originadas nos Estudos Organizacionais.

\section{PROBLEMA DE PESQUISA}

É neste contexto que está inserido o presente estudo, o qual busca investigar como as dimensões estruturais concebidas em um contexto de administração intraorganizacional de empresas se manifestam em sua aplicação na gestão da cadeia de suprimentos. Esta investigação justifica-se devido à ocorrência, nos últimos anos, de dimensões estruturais em pesquisas que analisam a cadeia de suprimentos. As tabelas 2 e 3 evidenciam a frequência desta ocorrência em vinte e oito artigos analisados. Deste modo, esta pesquisa investigou a plausibilidade e aplicação deste empréstimo conceitual no contexto da cadeia de suprimentos.

A ilustração 23 demonstra a sequência de execução das atividades para desenvolvimento da pesquisa.

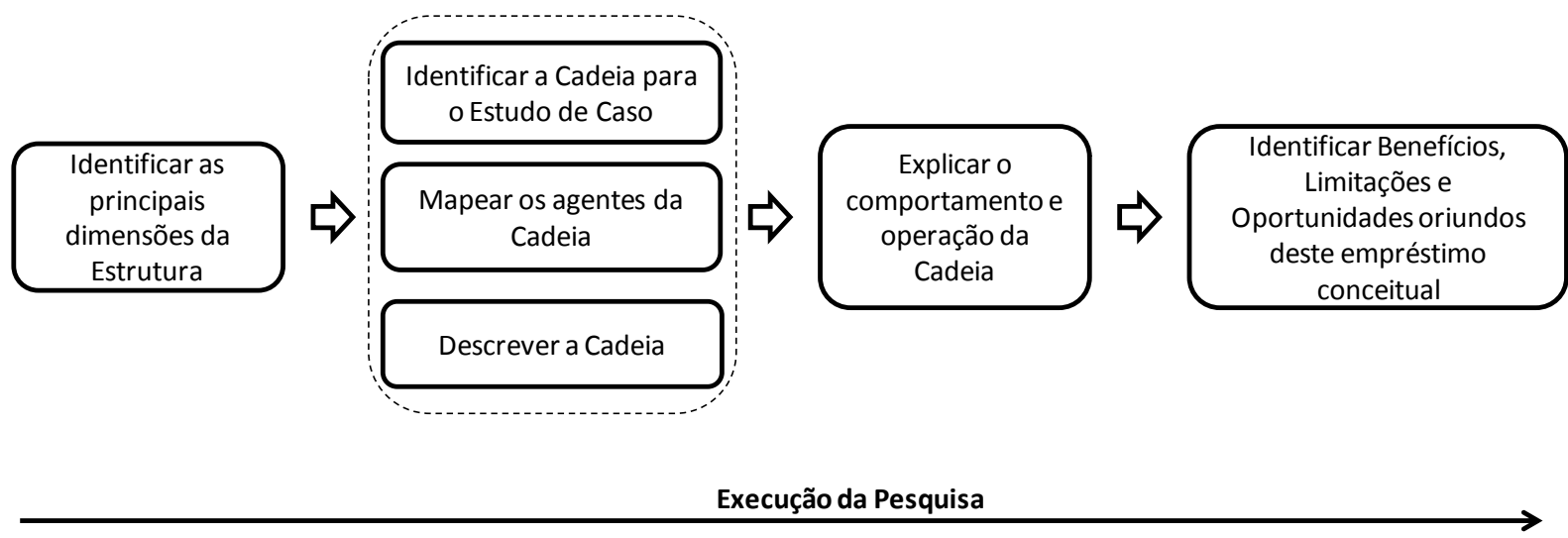

\section{Ilustração 23: Sequência de Execução da Pesquisa}

\section{OBJETIVOS GERAIS}

Para que seja possível responder ao Problema de Pesquisa, é necessário primeiramente responder a outras duas questões, os Objetivos Gerais. Estas objetivam compreender como a utilização das dimensões estruturais contribui para a Gestão da Cadeia de Suprimentos e o que as dimensões explicam sobre o seu comportamento e operação. Para que estas questões 
possam ser respondidas, foi identificada a necessidade de se encontrar uma cadeia real, a qual possa ser abordada na perspectiva das dimensões da estrutura organizacional.

\section{OBJETIVOS ESPECÍFICOS}

Assim, os Objetivos Gerais, por sua vez, foram desdobrados em três objetivos específicos.

O primeiro Objetivo Específico foi identificar quais as principais dimensões da análise de Estrutura Organizacional que são utilizadas pelas abordagens da Cadeia de Suprimentos. Foram analisados vinte e oito artigos, os quais trabalham diversas abordagens da cadeia. Nestes artigos, apareceram diversas vezes termos referentes às dimensões da estrutura da cadeia de suprimentos. A tabela 2 agrupou estes termos em quatro dimensões da teoria de Estrutura Organizacional e a tabela 3 evidenciou com qual frequência estas dimensões ocorreram. Assim, no item 2.3, por meio das tabelas 2 e 3, foram identificadas as quatro dimensões que foram utilizadas para a análise da cadeia real escolhida. As quatro dimensões identificadas foram: Centralização, Formalização, Complexidade e Integração. Após as dimensões terem sido identificadas, a teoria de Estruturas Organizacionais foi estudada para se compreender a definição destas em seu contexto original e como poderiam ser compreendidas no novo contexto, a Cadeia de Suprimentos.

Para esta pesquisa, foi escolhido o método Estudo de Caso, pois foi investigado o "como" as dimensões estruturais explicam o comportamento e a operação da cadeia de suprimentos. Assim, o segundo objetivo específico foi identificar uma cadeia real e representativa, a qual fosse adequada para a realização do Estudo de Caso. O caso escolhido foi o de uma cadeia de distribuição de medicamentos, na qual os agentes são a empresa farmacêutica, o operador logístico, os diversos fornecedores de serviços logísticos e os clientes finais da empresa farmacêutica. Estes foram mapeados conforme ilustração 19. Utilizar uma cadeia de distribuição, ou seja, uma cadeia de serviço de transportes é adequada, pois, segundo Tukker (2004), alguns serviços apresentam processos mais tangíveis como, por exemplo, os serviços de logística. Esta característica permite uma maior objetividade nas entrevistas porque são passíveis de medições e metas pelas empresas. Além disso, diversos autores apontam a falta de estudos de cadeias de serviços. Cirtita e Glaser-Segura (2012) ainda apontam que a carência de estudos é maior à jusante da empresa farmacêutica. Maiores detalhes sobre a escolha do caso foram discutidos no capítulo 4 item 4.1. Através da identificação e mapeamento desta cadeia, o segundo objetivo específico foi concluído.

O terceiro objetivo específico foi descrever a Cadeia de Serviços Logísticos, sob a perspectiva das dimensões da Estrutura Organizacional, apresentando suas limitações e oportunidades. A cadeia em questão foi descrita e analisada em detalhes no capítulo 5 Análise de Dados. A seguir, serão apresentados como as quatro dimensões estruturais descrevem a operação e comportamento da cadeia de serviços logísticos.

\section{INTEGRAÇÃO}

Para esta cadeia do setor farmacêutico, as quatro dimensões foram pertinentes. Porém, a dimensão integração, da forma como é descrita na teoria, praticamente não foi encontrada. Não foram encontradas iniciativas claras de integração e colaboração entre os agentes. Em momentos de crise operacional, foram desenvolvidas frentes de trabalho com alguma integração entre a Empresa farmacêutica e o Operador Logístico, porém estas não 
permaneceram após a crise. A cadeia se mostrou pobre em confiança entre os agentes. Por exemplo, o Operador Logístico proíbe, por contrato, que seus fornecedores possam ter algum contato com a Empresa farmacêutica. Esta questão mostra como a adaptação das teorias organizacionais para o contexto da cadeia de suprimentos necessita de uma discussão detalhada, como afirmou Ketchen e Hult (2010). Se a integração é analisada no contexto entre pessoas ou áreas dentro de uma organização, leva-se em conta que estas trabalham para uma mesma empresa, uma única gestão central, logo todos os interesses profissionais relacionados à empresa podem ser alinhados com maior facilidade. No caso das empresas da cadeia, nenhuma delas é $100 \%$ dependente de seu contratante; todas elas possuem outros clientes, o que pode significar menor envolvimento entre as empresas. Diferentemente de um fornecedor que atende um cliente com exclusividade, os fornecedores desta cadeia possuem diversos clientes e, assim, não conseguem dedicar a mesma atenção e cuidado, o que possivelmente aumentaria a integração, que é baseada na comunicação e confiança.

\section{CENTRALIZAÇÃO}

A empresa Air Cargo não é fornecedora exclusiva, mas possui $90 \%$ de seu faturamento do setor farmacêutico concentrados em um único cliente, a Eurochain. O impacto desta situação na dimensão centralização é evidente. Nesta relação, o poder é centralizado na Eurochain. A Air Cargo também é importante para a Eurochain, porém a Eurochain não é nada menos do que a própria sobrevivência da Air Cargo no setor, logo o poder é muito concentrado. O caso oposto é a relação entre a Air Cargo e as companhias aéreas de carga. Estas, além de transporte de carga, têm como principal negócio o transporte de passageiros, ou seja, sua renda secundária é do transporte de cargas. Neste contexto, a dinâmica de relação entre Air Cargo e a Companhia Aérea é inversa, pois aqui o fornecedor é quem concentra mais poder. Enquanto a Air Cargo possui pouco poder na relação com a Eurochain, a Companhia Aérea praticamente não sofre influência alguma da Air Cargo em sua operação. Isso contradiz a lógica de que a centralização do poder está relacionada à hierarquia da empresa na cadeia, ou seja, quanto mais próximo da "alta gestão", neste caso a empresa farmacêutica, maior a centralização do poder. Esta é lógica apontada por Kim (2006) e diversos outros autores. O caso da Air Cargo demonstra que, além da posição hierárquica, deve ser levado em consideração qual percentual da receita da empresa é oriundo da cadeia em questão e qual percentual é oriundo de outras cadeias. Caso o percentual oriundo de outras cadeias seja muito significativo, é possível que este fornecedor seja menos suscetível ao poder de outros agentes. A variável concorrência também deve ser discutida. O mercado de transporte aéreo de cargas apresenta apenas duas grandes concorrentes no Brasil, assim o poder de negociação da Air Cargo com as companhias aéreas se torna mais limitado ainda e a centralização do poder nas companhias aéreas cresce ainda mais.

A empresa farmacêutica também é outra empresa que concentra poder. Porém, ao que mostram as análises em seu relacionamento com o Operador Logístico, o poder é equilibrado entre os dois agentes. Isso pode ser explicado pelo poder que o Operador Logístico tem em seu tamanho, pois este é um dos maiores do mundo e possui muito volume de carga oriundo de outros clientes. Isto confere a ele um diferencial competitivo no processo de compras de transporte e, consequentemente, em seu preço de venda.

O quarto agente de destaque em poder na cadeia é o cliente final da empresa farmacêutica, os quais são grandes redes farmacêuticas e distribuidores. Estes se resumem a treze grandes clientes da empresa farmacêutica, os quais representam a maior parcela de seu faturamento. Devido este grande volume de compras, o poder destes clientes sobre o comercial e, consequentemente, sobre toda a empresa farmacêutica, é muito grande. Esta é 
uma questão importante, pois não foram identificados estudos que considerem o cliente final como um agente ativo na cadeia de distribuição, um agente que tome decisões sobre a operação. Na maioria dos casos, os clientes finais são tratados como simples recebedores de mercadoria. Ou seja, a questão comercial está diretamente relacionada com a questão operacional da cadeia de serviços de transportes de distribuição.

A empresa farmacêutica, seus clientes, o operador logístico e as companhias aéreas foram os agentes que apresentaram maior poder de influência no comportamento da cadeia. Em uma organização, o poder é centralizado e este é delegado conforme decisão da mais alta hierarquia. Já nesta cadeia, o poder é divido, porém não por vontade da mais alta hierarquia, mas por questões comerciais (concorrência, volume de vendas, percentual de receita etc.), ou seja, independente da vontade da empresa farmacêutica, ela terá dificuldades para impor sua vontade sobre os outros três agentes. Apesar de ser externa à cadeia, a ANVISA influencia diretamente a operação da cadeia pelo uso da legislação.

Estes exemplos mostram que mais variáveis - como a concorrência e percentual da receita gerada nesta cadeia - precisam ser analisados com profundidade para que este empréstimo conceitual tenha validade, caso contrário não será possível explicar o comportamento da cadeia.

\section{COMPLEXIDADE}

A dimensão complexidade, dada pela dispersão geográfica, diferenciação vertical e horizontal e o número de modais utilizados, pode explicar em parte a dificuldade da integração na cadeia. Boyle, Humphreys e McIvor (2008) apontam que quanto mais complexa for a cadeia, menos consistente e mais ambígua será a comunicação. A comunicação ruim entre os agentes desta cadeia pode ser explicada pela sua grande complexidade, contando com mais de quatro níveis verticais (quatro subcontratações), mais de cem empresas no último nível (diferenciação horizontal), dispersão geográfica equivalente à extensão do Brasil e a utilização de dois modais de transporte (aéreo e rodoviário). Todos estes fatores dificultam a comunicação que, por sua vez, prejudica a Integração. Ainda é necessário considerar a confiança, que é um fator crítico e está em falta na cadeia analisada.

Boyle, Humphreys e McIvor (2008) apontam que, em cadeias de alta complexidade, devido à dificuldade de gestão e tomada de decisão, pode ocorrer maior descentralização. $\mathrm{Ou}$ seja, é dada maior autonomia para os fornecedores, inclusive para a contratação de seus próprios fornecedores. A Eurochain parece ter tomado um caminho oposto ao que a teoria indica, pois eles cotaram preços diretamente com as companhias aéreas, que são os fornecedores de seu fornecedor. Embora pareça um movimento de centralização, menos autonomia para o fornecedor, este parece estar mais relacionado à retirada de um intermediário e aumento da margem de lucro do que realmente uma centralização. $\mathrm{O}$ transporte aéreo é o mais caro e representa uma parcela significativa de seus custos. $O$ fator custo, neste exemplo, influenciou a dimensão Centralização. A subcontratação dos transportes rodoviários, que possuem menor preço, foi delegada aos transportadores terceirizados. O fator custo também precisa ser levado em conta quando for analisada a dimensão centralização.

Neste contexto de alta complexidade, a função do Operador Logístico como gestor da cadeia e de diversos fornecedores é muito coerente, conforme apontam Boyle, Humphreys e McIvor (2008) sobre as empresas com função de intermediadores. Caso não houvesse o operador logístico, a empresa farmacêutica teria que lidar com treze fornecedores diretos, ao 
invés de um, o que aumenta consideravelmente o seu trabalho de gestão em uma cadeia complexa.

A dimensão Complexidade mostra como uma dimensão afeta as outras. A Complexidade pode afetar a comunicação, que afeta a Integração. A Complexidade também pode incentivar a delegação, que por sua vez impacta na Centralização. Porém, esta também é influenciada pelos altos custos de seus fornecedores. Ou seja, é necessário que sejam identificadas todas as diversas variáveis que influenciam nas tomadas de decisão da cadeia para que, através destas, seja possível, em uma pesquisa futura, determinar um modelo conceitual que viabilize analisar as mais variadas cadeias de suprimento na perspectiva das dimensões estruturais.

\section{FORMALIZAÇÃO}

O setor farmacêutico é reconhecido por ser rigorosamente fiscalizado pela vigilância sanitária. Neste contexto, com já era esperado, a dimensão formalização foi encontrada. As empresas desta cadeia possuem três pontos de preocupação que motivam a alta formalização. são eles:

- $\quad$ forte regulamentação da Agência Nacional de Vigilância Sanitária (ANVISA).

- $\quad$ alto valor da carga e respectiva necessidade de gerenciamento de riscos.

- $\quad$ atendimento de alta qualidade que é demandado no setor de saúde.

Apesar do forte controle da ANVISA, foi apontado em entrevista que esta vigilância não ocorre com a mesma intensidade em todos os pontos da cadeia. a pesquisa levantou que, quanto mais à jusante ou mais próximo do cliente final, menor é a formalidade, desde que não sejam considerados os grandes centros e as capitais, nas quais a vigilância permanece alta.

Após discutir os três objetivos específicos, é possível explicar a operação e o comportamento da cadeia, respondendo ao Objetivo Geral.

\section{RESPOSTA AOS OBJETIVOS GERAIS}

Embora existam diversas ressalvas, as quatro dimensões estruturais colaboram na compreensão sobre o comportamento e operação da cadeia, da seguinte forma:

- $\quad$ A Integração demonstra se a cadeia está pronta ou não para buscar objetivos comuns ou, inclusive, competir com outras cadeias.

- A Centralização explica parte do comportamento da cadeia. Por exemplo, quem são os tomadores de decisão, por que terceirização, por que delegar poder, como criar ou alterar regras e procedimentos, quais fatores influenciam na negociação de preços e outras questões.

- A Complexidade apresenta a intensidade dos esforços e a quantidade de investimentos que a cadeia demanda para ser gerida. Por exemplo, em casos de maior complexidade pode ser necessária a contratação de um Operador Logístico.

- $\quad$ A Formalização demonstra o quanto a cadeia já está apta a seguir regras e procedimentos ou se serão necessários muitos investimentos em comunicação e treinamento.

Considerando as respostas acima do objetivo geral, as contribuições para a gestão da cadeia de suprimentos estão relacionadas às melhores tomadas de decisão e definição de 
melhores estratégias. Por exemplo, investimentos de comunicação e treinamento na cadeia, estratégias de terceirização (contratação ou não de um operador logístico), estratégias de delegação de poder ao fornecedor (por exemplo, o Operador Logístico foi contratar diretamente os fornecedores de seu fornecedor), necessidade de reforçar relacionamentos comerciais (por exemplo, relacionamento com Companhias Aéreas, Redes de Drogarias e Distribuidores) e estratégias de venda. Mesmo considerando as ressalvas, as quatro dimensões podem auxiliar na gestão da cadeia de suprimentos.

\section{RESPOSTA AO PROBLEMA DE PESQUISA}

As quatro dimensões estruturais se manifestam, esclarecendo alguns fenômenos da cadeia de suprimentos; entretanto, também levantam questões que não foram discutidas e respondidas na teoria de Estrutura Organizacional. Os benefícios de sua utilização já foram apresentados nas respostas dos Objetivos Gerais. As limitações deste empréstimo conceitual se encontram nas diferenças entre uma cadeia de suprimentos e uma organização. Essas diferenças se manifestam, principalmente, nas dimensões Integração e Centralização, as quais influenciam todas as outras dimensões e diversos comportamentos da cadeia. Estas dimensões diferem, principalmente, no que diz respeito à concentração de poder de tomada de decisão no nível mais alto da hierarquia. Na cadeia em questão, isto não foi encontrado. Pelo contrário, o poder estava distribuído entre quatro agentes. Isto alterou toda a dinâmica da cadeia. Por isso, este ponto é uma limitação da utilização da teoria de Estruturas Organizacionais na Cadeia de Suprimentos. Para que esta limitação seja superada, é preciso que este tema seja explorado em pesquisas futuras. Ainda é necessário identificar e compreender todas as variáveis (legislação, serviços de maior valor agregado, concorrência, percentual de receita por cliente, histórico comercial, diferenciais competitivos, complexidade da cadeia, volume de produtos e etc.) que influenciam na concentração de poder em um agente, uma vez que estas forem conhecidas e explicadas poderá ser desenvolvido um modelo para aplicação das dimensões estruturais nas mais variadas cadeias de suprimentos.

Enfim, as ressalvas encontradas na aplicação desta teoria no contexto da Cadeia de Suprimentos precisam ser analisadas em profundidade, como disseram Ketchen e Hult (2010). Neste contexto, ainda há necessidade de desenvolvimento de um modelo robusto que permita esta aplicação com confiabilidade em cadeias diversas, respeitando as particularidades que cada contexto exige.

A tabela 21 apresenta um resumo das análises das dimensões na cadeia de suprimentos. 
Tabela 21: Interpretação das dimensões na cadeia em análise

\begin{tabular}{|c|c|c|}
\hline Dimensões & Teoria Organizacional & Cadeia Analisada \\
\hline Centralização & $\begin{array}{l}\text { Relativo à concentração } \\
\text { de poder e tomada de } \\
\text { decisão em um nível da } \\
\text { alta gestão (ROBBINS, } \\
\text { 1983) (GIBSON, } \\
\text { IVANCEVICH E } \\
\text { DONNELLY, 1991) } \\
\text { (PRICE, 1972) }\end{array}$ & $\begin{array}{l}\text { Na teoria Organizacional, esta dimensão é } \\
\text { avaliada com base na concentração de } \\
\text { poder no nível mais alto da hierarquia. Na } \\
\text { cadeia analisada, o poder é dividido } \\
\text { independente da vontade da alta } \\
\text { hierarquia (indústria). Esta divisão ocorre } \\
\text { com base no poder comercial de cada } \\
\text { empresa. As quatro que mais concentram } \\
\text { poder são: Redes de Drogarias e } \\
\text { Distribuidores, Indústria, Operador } \\
\text { Logístico e Companhias Aéreas. Se } \\
\text { considerarmos os agentes externos, deve } \\
\text { ser citada também a ANVISA que, } \\
\text { através da legislação e fiscalização, } \\
\text { interfere diretamente na operação }\end{array}$ \\
\hline Complexidade & $\begin{array}{l}\text { Diferenciação Vertical } \\
\text { (quantidade de níveis } \\
\text { hierárquicos), Horizontal } \\
\text { (quantidade de } \\
\text { áreas/indivíduos por } \\
\text { nível) e Dispersão } \\
\text { Espacial (ou geográfica). } \\
\text { Quanto maior a } \\
\text { organização maior a } \\
\text { complexidade } \\
\text { (ROBBINS, 1983) } \\
\text { (PRICE, 1972) }\end{array}$ & $\begin{array}{l}\text { Considerando que o poder na cadeia } \\
\text { analisada não é centralizado como em } \\
\text { uma organização, os esforços e } \\
\text { investimentos para lidar com a } \\
\text { complexidade são maiores na cadeia do } \\
\text { que em uma organização. Uma } \\
\text { organização com poder centralizado no } \\
\text { presidente terá menos desgaste para } \\
\text { implantar uma nova política corporativa } \\
\text { através de toda a organização do que uma } \\
\text { cadeia que possuiu o poder dividido entre } \\
\text { quatro agentes que precisarão negociar } \\
\text { entre si }\end{array}$ \\
\hline Formalização & $\begin{array}{l}\text { Relativo ao nível de } \\
\text { regras explícitas na } \\
\text { Organização (GIBSON, } \\
\text { IVANCEVICH E } \\
\text { DONNELLY, 1991) e } \\
\text { (PRICE, 1972) }\end{array}$ & $\begin{array}{l}\text { Para Hall (1982), a formalização deveria } \\
\text { aumentar na organização conforme o } \\
\text { nível hierárquico diminui, pois os } \\
\text { gestores mais juniores precisam de mais } \\
\text { regras e não podem ter muita autonomia } \\
\text { ainda. Na cadeia em questão, a legislação } \\
\text { e a fiscalização determinaram o inverso } \\
\text { do proposto por Hall (1982), pois o rigor } \\
\text { da fiscalização diminui quanto mais longe } \\
\text { se está da indústria ("alta hierarquia") e } \\
\text { assim as empresas que atuam na "ponta } \\
\text { de distribuição" sentem-se mais à vontade } \\
\text { para não ter regras formalizadas }\end{array}$ \\
\hline
\end{tabular}




\begin{tabular}{|l|l|l|}
\hline & $\begin{array}{l}\text { É a capacidade de } \\
\text { colaboração entre os } \\
\text { departamentos para que } \\
\text { estes trabalhem em grupo } \\
\text { e atinjam um único } \\
\text { conjunto de esforços } \\
\text { Integração }\end{array}$ & $\begin{array}{l}\text { Diversos autores defendem que a } \\
\text { organização precisa trabalhar com um } \\
\text { objetivo estratégico comum, o qual é } \\
\text { desdobrado em planos de ação táticos e } \\
\text { operacionais, por exemplo, através do } \\
\text { Balanced Scorecard. Na cadeia em } \\
\text { questão, existe um objetivo comum, que é } \\
\text { organizacionais } \\
\text { (ROBBINS, 1983) }\end{array}$ \\
$\begin{array}{l}\text { o transporte de medicamentos. Entretanto, } \\
\text { não foi detectada integração. Logo, nesta } \\
\text { cadeia, mesmo sem um planejamento } \\
\text { único entre os diversos agentes, cada } \\
\text { díade cliente-fornecedor consegue se } \\
\text { organizar de forma que o todo funcione. }\end{array}$ \\
\hline
\end{tabular}

\section{LIMITAÇÕES E PESQUISAS FUTURAS}

A análise da estrutura organizacional no contexto da cadeia de suprimentos envolve todos os seus agentes, porém considera o cliente final (o cliente da empresa farmacêutica) como um ator passivo, sendo apenas um recebedor da mercadoria, o que é questionável segundo levantado por esta pesquisa. Esta abordagem do cliente final se mostrou incompleta neste estudo. É de extrema necessidade que novas pesquisas analisem com profundidade o perfil e a participação do cliente final para entender o comportamento de toda a cadeia. Estes clientes, grandes redes de drogarias e distribuidores, mostraram-se influenciadores diretos das atividades de boa parte das empresas prestadoras de serviço da cadeia. Estes apresentaram alta centralização de poder, sendo que, mesmo executando práticas fora do mercado que provocam aumento de custos dos outros agentes, não foram contestados e, assim, ainda continuam com comportamentos oportunistas que prejudicam os outros. Analisar com profundidade o papel destes clientes é uma proposta para pesquisa futura, bem como a investigação com profundidade das companhias aéreas que alteram a dinâmica da cadeia também.

Para analisar a dimensão complexidade, foi necessário mapear os agentes da cadeia. Entretanto, para mapeá-los seria necessário entrevistar no mínimo mais onze empresas, o que tornaria inviável a pesquisa. Esta foi uma limitação encontrada, por isso foi feita uma estimativa do total de transportadores subcontratados. Outra limitação foi a não participação dos subcontratados nas pontas. Seria importante ouvir os últimos transportadores da cadeia os quais fazem as entregas finais - para coletar mais evidências e poder constatar com segurança a baixa formalização encontrada. 


\section{BIBLIOGRAFIA}

AKKERMANS, H; VOSS, C. The service bullwhip effect. International Journal of Operations \& Production Management, Coventry, v. 33, n. 6, p. 765-788, 2013.

ASHENBAUM, B.; SALZARULO, P. A.; NEWMAN, W. R. Organizational Structure, Entrepreneurial Orientation and Trait Preference in Transportation Brokerage Firms. Journal of Supply Chain Management, 2012.

AUSTIN, J. The Collaboration Challenge: how nonprofits and business succeed through strategic alliances. [S.1.]:Jossey-Bass, 2001.

AUTRY, C. W.; GRIFFIS, S. E. Supply chain capital: the impact of structural and relational linkages on firm execution and innovation. Journal of Business Logistics, 2008.

AYERS, J. Handbook of Supply Chain Management. Boca Raton: St Lucie Press, 2001.

BALTACIOGLU, T.; ADA, E.; KAPLAN, M.; YURT, O. e KAPLAN, C. A new framework for service supply chains. Services Industry Journal, v. 27, n. 2, p. 105-124, 2007.

BEAMON, B. M. Supply chain design and analysis: Models and methods. International Journal of Production Economics, p. 281-294, 1998.

BLAU, P. M. Organizações Formais 1 ed. São Paulo:Atlas, 1977BRUNT, D. From current state to future state: mapping the steel to component supply chain. International Journal of Logistics, 2000.

BORGATTI, S. P.; LI, X. On Social Network Analysis In a Supply Chain Context. Journal of Supply Chain Management, 2009.

BOYLE, E.; HUMPHREYS, P.; MCIVOR, R. Reducing Supply Chain Environmental Uncertainty through e-Intermediation: An Organization Theory Perspective. International Journals of Production Economics, 2008.

BOZARTH, C. C.; WARSING, D. P.; FLYNN, B. B.; FLYNN, E. J. The impact of Supply Chain Complexity on Manufacturing Plant Performance. Journal of Operations Management. v.27 p.78-93, 2009.

BRUNT D. From Current State to Future State: Mapping the Steel to Component Supply Chain.International Journal of Logistics, 2000.

CARTER, C. R.; ELLRAM, L. M. The Use Of Social Network Analysis In Logistics Research. Journal Of Business Logistics, 2007.

CARTER, C. R.; LEUSCHNER, R.; ROGERS, D. S. A Social Network Analysis of the Journal of Supply Chain Management: Knowledge Generation, Knowledge Diffusion and Thought Leadership. The Journal of Supply Chain Management, 2007.

CHASE, R.B. Where does the customer fit in a service operation? Harvard Business Review, 1978. 
CHIAVENATO, I. Introdução à Teria Geral da Administração 5ed. Rio de Janeiro: Campus, 1999.

CHOI, T.Y; HONG, Y. Unveiling the structure of supply networks: case studies in Honda, Acura, and DaimlerChrysler. Journal of Operations Management, p. 469-493, 2002.

CHOI, T. Y.; KIM, Y. Strutural Embeddedness and supplier management: a network perspective. Journal of Supply Chain Management, 2008.

CHOI, T. Y.; DOOLEY, K. J. e RUNGTUSANATHAM, M. Supply networks and complex adaptive systems: control versus emergence. Journal of operations management, 2001.

CHOW, D.; HEAVER, T.; \& HENRIKSSON, L. Logistics performance: Definition and measurement. International Journal of Physical Distribution \& Logistics Management, v. 24, n. 1, p. 17-28, 1994.

CHOW, D.; HEAVER, T. Logistics strategies for North America. Global Logistics and Distribution Planning, $3^{\text {a }}$ edição, 1999.

CIRTITA, H.; GLASER-SEGURA, D. A. Measuring Downstream Supply Chain Performance. Journal of Manufacturing Technology Management. v. 23, n. 3, p. 299-314, 2012.

COOPER, M. C.; LAMBERT, D. M.; PAGH, J. D. Supply Chain Management: More Than a New Name for Logistics International. Journal of Logistics Management, 2006.

CONSELHO DOS PROFISSIONAIS DE GESTÃO DA CADEIA DE SUPRIMENTOS DOS ESTADOS UNIDOS. Council of Supply Chain Management Professionals. Supply Chain management/logistics management definitions. Disponível em:

< http://www.cscmp.org/Website/AboutCSCMP/Definitions/Definitions.asp>. Acesso em 20 de Maio de 2013.

CORBETT, C. J.; BLACKBURN, J. D.; VAN WASSENHOVE, L. N. Case Study Partnerships to Improve Supply Chains. MIT Sloan Management Review, v. 40, n. 4, p. 71, 1999.

CORSTEN, D; KUMAR, N. Do Suppliers Benefit from Collaborative Relationships with Large Retailers? An Empirical Investigation of Efficient Consumer Response Adoption. Journal of Marketing, 2005.

COUGHLAN, P.; et al. Managing Collaborative Relationships in a Period of Discontinuity. International Journal of Operations \& Production Management, v. 23, n. 10, p. 1246-1259, 2003.

COX, A.; SANDERSON, J.; WATSON, G. Supply Chains and Power Regimes: Toward an Analytic Framework for Managing Extended Networks of Buyer and Supplier Relationships. Journal of Supply Chain Management, 2001.

CRESWELL, J. W. Projeto de pesquisa. Métodos qualitativo, .quantitativo e misto. 2 Ed. São Paulo: Artmed, 2007. 
DAFT, R. L. Administração 6ed. São Paulo:Pioneira Thomson Learning, 2005

DAS, T. K.; TENG, B. S. Between trust and control: developing confidence in partner cooperation in alliances. Academy of Management Review, v. 23, n. 3, p. 491-512, 1998.

DRAKE M. J.; SCHLACHTER J. T. A Virtue-Ethics Analysis of Supply Chain Collaboration. Journal of Business Ethics, 2008

DYER, J. H.; SINGH, H. The relational view: cooperative strategy and sources of interorganizational competitive advantage. Academy of Management Review, v. 23 n. 4, p. 66079, 1998.

ELLRAM, L.; TATE, W.; BILLINGTON, C. Understanding and managing the services supply chain. Journal of Supply Chain Management, v.40, n. 4, p. 17, 2004.

ETZIONI, A. Organizações Modernas 5 ed. São Paulo:Pioneira, 1964

FIGUEIREDO, K. F.; MORA, D. M. M. A Segmentação dos Operadores Logísticos no Mercado Brasileiro de acordo com suas Capacitações para Oferecer Serviços. Revista de Administração Contemporânea, Curitiba, v. 3, n. 1, art. 7, p. 123-141, 2009.

FINE, C. Clockspeed: Winning Industry Control in the Age of Temporary Advantage. Perseus Books: Reading, 1998.

FLEURY, P. F.; WANKE, P. e FIGUEIREDO, K. F. Logística empresarial: a perspectiva brasileira. São Paulo: Atlas, p. 372, 2000.

GALASKIEWICZ, J. Studying supply chains from a social network perspective. Journal of Supply Chain Management, v. 47, n. 1, p. 4, 2011.

GARDNER, J. T.; COOPER, M. C. Strategic supply chain mapping approaches. Journal of Business Logistics, v. 24, n. 2, 2003.

GIANNAKIS, M. Management of service supply chains with a service-oriented reference model: the case of management consulting. Journal of Supply Chain Management, v. 16, n. 5, p. 346-361, 2011.

GIANNAKIS, M.; CROOM, S. R. Toward the Development of a Supply Chain Management Paradigm: A Conceptual Framework. The Journal of Supply Chain Management, 2004.

GIBSON, J. L.; IVANCEVICH, J. M.; DONNELLY, J. H. Organizations Behavior Structure Processes. 7 ed. Irwin, 1991.

GIL, A. C. Como elaborar projetos de pesquisa. São Paulo: Atlas: 1991.

GREVE, H. R. Bigger and Safer: The Diffusion of Competitive Advantage. Strategic Management Journal, 2008.

HA, B.; PARK, Y.; CHO, S. Suppliers' affective trust and trust in competency in buyers: Its effect on collaboration and logistics efficiency. International Journal of Operations \& Production Management. v. 31, n. 1, p. 56 - 77, 2010. 
HAARTVEIT, E. Y.; KOZAK, R. A.; MANESS, T. C. Supply chain management mapping for the forest products industry: Three cases from western Canada. Journal of Forest Products, 2004 ,

HALL, R. H. Organizações: Estrutura e Processos. Rio de Janeiro:Prentice-Hall,1982.

HALLDÓRSSON, A.; SKJØTT-LARSEN, T. Developing logistics competencies through third party logistics relationships. International Journal of Operations \& Production Management. p. 192, 2004.

HAMEL, G. Competition for competence and interpartner learning within international strategic alliances. Strategic Management Journal, 1991.

HARZING, A. W. Publish or Perish, 2007, Disponível em: <http://www.harzing.com/pop.htm>. Acesso em 15 de Abril de 2013.

HARLAND, C. M.; LAMMING, R. C.; ZHENG, J.; JOHNSEN, T. E. A Taxonomy of Supply Networks. Journal of Supply Chain Management, 2001.

HARLAND, C. M.; LAMMING, R. C.; COUSINS, P. D. Developing the concept of supply strategy International. Journal of Operations \&Production Management, 1999.

HEARNSHAW, E. J. S.; WILSON, M. M. J. A complex network approachto supply chain network theory. International Journal of Operations \& Production Management, 2013.

HINES, P.; RICH, N. The Seven Value Stream Mapping Tools. International Journal of Operations \& Production Management, v.17, n.1, p.46-64, 1997.

HITT, M. A. Relevance of Strategic Management Theory and Research for Supply Chain Management. Journal of supply Chain Management, 2011.

Instituto Brasileiro de Geografia e Estatística - IBGE - PESQUISA ANUAL DE SERVIÇOS 2011 -. Disponível em:

<ftp://ftp.ibge.gov.br/Comercio_e_Servicos/Pesquisa_Anual_de_Servicos/pas2011/pas2011.p df> Acesso em 06 de Agosto de 2014.

JANVIER-JAMES, A. M. A New Introduction to Supply Chains and Supply Chain Management: Definitions and Theories Perspective. International Business Research, v. 5, n. 1, p. 194, 2012.

JARILLO, J. C.; STEVENSON, H. H. Co-operative Strategies-The Payoffs and the Pitfalls. Long Range planning, 1991.

JCR Journal Citation Reports. Thomson Reuters. Disponível em: < http://thomsonreuters.com/journal-citation-reports/>.

JONES, D.; WOMACK, J.P. Seeing the Whole: Mapping the Extended Value Stream. Lean Enterprise Institute, 2002.

JONES, G. R. Organizational Theory Text and Cases. 3 ed. New Jersey:Prentice Hall, 2001. 
KAPLAN, R. S.; NORTON, D. P.; \& RUGLESJOEN, B. Managing alliances with the balanced scorecard. Harvard Business Review , 2010.

KEQIANG, W.; ZHAOFENG, Z.; DONGCHUAN, S. Structure Analysis of Supply Chain Networks Based on Complex Network Theory. Fourth International Conference on Semantics, Knowledge and Grid, 2008.

KETCHEN, D. J.; HULT, G. T. M. Bridging organization theory and supply chain management: The case of best value supply chains. Journal of Operations Management, 2006.

KETCHEN, D. J.; HULT, G. T. M. Toward greater integration of insights from organization theory and supply chain management. Journal of Operations Management, 2007.

KETCHEN, D. J.; HULT, G. T. M. Building Theory about Supply Chain Management: Some Tools From Organizational Sciences. Journal of Supply Chain Management, 2010.

KETCHEN, D. J.; HULT, G. T. M. Building Theory about supply chain management: some tools from the organizational sciences. Journal of Supply Chain Management, v. 47, n. 2, 2011.

KIM, S. W. Organizational structures and the performance of supply chain management. International Journal of Production Economics, 106, p.323-345, 2006.

KIM, Y.; CHOI, T. Y.; YAN, T.; DOOLEY, K. Structural investigation of supply networks: A social network analysis approach. Journal of Operations Management, 2010.

KNEMEYER, A. M.; MURPHY, P. R. Evaluating the Performance of Third-Party Logistics Arrangements: A Relationship Marketing Perspective. The Journal of Supply Chain Management, 2004.

KOPCZAK, L. R. Logistics Partnerships and Supply Chain Restructuring: Survey Results From the U.S. Computer Industry. Production and Operation Management, v. 6, n. 3, 1997.

KUMAR, N. S.; BHARATHIB P. S. Continuous supply chain collaboration: Road to achieve operational excellence. Management Science Letters, 2011.

LAMBERT, D. M.; COOPER, M. C. Issues in Supply Chain Management. Industrial Marketing Management, v. 29, p. 65-83, 2000.

LAMMING, R.; JOHNSEN, T.; ZHENG, J.; HARLAND, C. An initial classification of supply networks. International Journal of Operations \& Production Management, 2000.

LAWRANCE, P. R.; LORSCH, J. W. O Desenvolvimento de organizações: diagnóstico e ação. São Paulo: Edgard Blücher Ltda, 1972.

LEE, P. D. Measuring Supply Chain Integration: A Social Network Approach Supply Chain Forum. An International Journal, 2005.

LEEUW, S; FRANSOO, J. Drivers of close supply chain collaboration: one size fits all? International Journal of Operations \& Production Management, v. 29, n. 7, p. 720 - 739, 2009. 
LITTLE, A. European Supply Chain (SC) survey, 2011. Disponível em: <http://www.adlittle.be/insights/studies/pdf/european_supply_chain_survey.pdf $>$. Acesso em 09 de Abril de 2014.

MABERT, V. A.; VENKATARAMANAN, M. A. Special research focus on supply chain linkages: challenges for design and management in the 21 st century. Decision Sciences 29 (3), 537-552, 1998.

MARTINS, G. A.; THEÓPHILO, C. R. Metodologia da Investigação Científica para Ciências Sociais Aplicadas. São Paulo: Atlas, 2009.

MCFARLAND, D.; MOLL, S. B. Social Network Image Animator. Disponível em: $<$ http://www.stanford.edu/group/sonia>. Acesso em 08 de Maio de 2013.

MCGINNIS, M. A.; KOCHUNNY, C. M.; ACKERMAN, K. B. Third Party Logistics Choice. The International Journal of Logistics Management, v. 6, n. 2, p. 93 - 102, 1995.

MENTZER, J.; WITT, W. D.; KEEBLER, J.; MIN, S.; NIX, N.; SMITH, D.; ZACHARIA, Z. Defining Supply Chain Management. Journal of Business Logistics, v.22, n. 2, 2001.

MILES, H.; HUBERMAN, M. Qualitative Data Analysis: A Sourcebook, Sage Publications, Berverlu Hills, 1994.

MILES, R. E.; SNOW, C. C. Organization theory and supply chain management: An evolving research perspective. Journal of Operations Management, p. 459-463, 2007.

MIN, H.; ZHOU, G. Supply Chain modeling: past, present and future. Computers \& Industrial Engineering, 2002.

MIYAKE, D. I.; TORRES JUNIOR, A. S.; FAVARO, C. Supply chain mapping initiatives in the Brazilian automotive industry: challenges and opportunities. Journal of Operations and Supply Chain Management, 2010.

NASCIMENTO, P. T. Organização: critérios para uma concepção crítica e objetiva. Cadernos Ebape, Rio de Janeiro, v. 7, n. 4, 2009.

OU C. S.; LIU F. C.; HUNG Y. C.;YEN D. C. A structural model of supply chain management on firm performance. International Journal of Operations \&Production Management, v. 30 n. 5, 2010.

PATHAK, S. D.; DAY, J. M.; NAIR, A.; SAWAYA, W. J.; KRISTAL, M. M. Complexity and Adaptivity in Supply Networks: Building Supply Network Theory Using a Complex Adaptive Systems Perspective*. Decision Sciences, 2007.

PIENAAR, W. Introduction to Business Logistics. Africa do Sul: Oxford University. 2009

POWELL, W. W.; KOPUT, W.K.; SMITH-DOER, L. Interorganizational Collaboration and the Locus of Innovation: Networks of Learning in Biotechnology. Administrative Science Quarterly, 1996. 
POLLOCK, T. G.; PORAC, J. F.; WADE, J. B. Constructing Deal Networks: Brokers as Network ""Architects"" in the U.S. Ipo Market and Other Examples. Academy of Management Review, 2004

PRICE, J. L. Handbook of Organizational Measurement. D. C. Heath and Company, 1972.

ROBBINS, S. P. Organization Theory - The Structure and Design of Organizations. New Jersey:Prentice-Hall, 1983.

SAMPSON, S. E. Visualizing service operations. Journal of Service Research, v. 15, n. 2, p. 182-198, 2012.

SAMPSON, S. E.; FROEHLE, C. M. Foundations and implications of a proposed unified services theory. Production and Operations Management, v. 15, n. 2, p. 329 -343, 2006.

SASSER, W. E. Match supply and demand in the service industries. Harvard Business Review, 1976.

SCOTT, C.; WESTBROOK.R. New Strategic Tools for Supply Chain Management. International Journal of Physical Distribution \& Logistics Management. v.21, n.1, p.23-33, 1991.

SIMCHI-LEVI, D.; KAMINSKY, P.; SIMCHI-LEVI, E. Cadeias de Suprimentos Projeto e Gestão - Conceitos, Estratégias e Estudo de Caso. Porto Alegre: Bookman, 2010.

STOCK, G. N.; GREIS, N. P.; KASARDA, J. D. Enterprise logistics and supply chain structure: the role of fit. Journal of Operations Management, v. 18, p. 531-547, 2000.

SOOSAY C. A.; HYLAND P. W.; FERRER, M. Supply chain collaboration: capabilities for continuous innovation Supply Chain Management. An International Journal, v. 13, n. 2, p. 160-169, 2008.

THE SUPPLY CHAIN COUNCIL, Inc., Supply-Chain Operations Reference-model: Overview of SCOR Version 10.0, Cypress. Acessível em <http://supply-chain.org/f/SCOROverview-Web.pdf $>$. Acesso em 14 de Novembro de 2013.

TORRES JUNIOR., A. S.; RATÃO, B. P. Relacionamento na Cadeia de Abastecimento Estudo de Caso em uma Pequena Empresa Distribuidora. Gestão \& Regionalidade, vol. 27, núm. 79, enero-abril, 2011

TOWILL, D.R., CHILDERHOUSE, P.; DISNEY, S.M. Speeding Up Progress Curve Towards Effective Supply Chain Management. Supply Chain Management: an International Journal. v.5, n.3, p.122-130, 2000.

TUKKER, A. Eight types of product-service system: Eight ways to sustainability? Experiences from SusProNet. Business Strategy and the Environment, v. 13, p. 246-260, 2004.

VARGO, S. L.; LUSCH, R. F. Evolving towards a new dominant logic for marketing. Journal of Marketing, v. 68, n. 1, p. 1-17, 2004. 
VEREECKE, A.; STEVE, M. S. Performance improvement through supply chain collaboration in Europe. International Journal of Operations \& Production Management, v. 26, n. 11, p. 1176-1198, 2006.

VIVALDINI, M.; PIRES, S. R. I. Operadores Logísticos: Integrando Operações em Cadeias de Suprimento. São Paulo: Atlas, 2010. p. 215.

WEBQUALIS. Sicapes - Sistema Integrado Capes. Disponível em: < http://qualis.capes.gov.br/webqualis/principal.seam>. Acesso em 05 de Abril de 2013.

WOOD Jr. T.; ZUFFO P. K. Supply chain Management. Revista de Administração de Empresas, São Paulo, v. 38, n. 3, p. 55-63, 1998.

YEE, C. L.; TAN, K. H. A process and tool for supply network analysis Industrial Management + Data Systems, 2004.

YIN, R. Estudo de Caso. Planejamento e Métodos. 4 ed. Porto Alegre: Bookman, 2010.

ZAHEER, A.; BELL, G. G. Benefiting from Network Position: Firm Capabilities, Structural Holres, And Performance. Strategic Management Journal, 2005. 


\section{Anexos}

8.1 Anexos I - Tabela dos melhores Journals de Operações e Supply Chain (WebQualis e JCR)

\begin{tabular}{|c|c|c|c|c|}
\hline & \multicolumn{4}{|c|}{ JCR } \\
\hline WebQualis & nome & issn & citações & Fator de impacto ult 5 anos \\
\hline B1 & JOURNAL OF OPERATIONS MANAGEMENT & 0272-6963 & 4825 & 7,13 \\
\hline - & $\begin{array}{c}\text { M\&SOM-Manufacturing \& Service } \\
\text { Operations Management }\end{array}$ & $1523-4614$ & 1064 & 2,561 \\
\hline A1 & OPERATIONS RESEARCH & $0030-364 X$ & 8311 & 2,484 \\
\hline B1 & $\begin{array}{c}\text { INTERNATIONAL JOURNAL OF } \\
\text { OPERATIONS \& PRODUCTION } \\
\text { MANAGEMENT }\end{array}$ & 0144-3577 & 2910 & 2,285 \\
\hline B1 & Operations Management Research & $1936-9735$ & 43 & não tem \\
\hline A2 & $\begin{array}{c}\text { PRODUCTION AND OPERATIONS } \\
\text { MANAGEMENT }\end{array}$ & 1059-1478 & 1794 & 1315 \\
\hline - & $\begin{array}{c}\text { International Journal of Logistics } \\
\text { Management }\end{array}$ & 0957-4093 & 801 & 1.463 \\
\hline - & $\begin{array}{c}\text { INTERNATIONAL JOURNAL OF PHYSICAL } \\
\text { DISTRIBUTION \& LOGISTICS } \\
\text { MANAGEMENT }\end{array}$ & 0960-0035 & 1787 & 1.826 \\
\hline A1 & $\begin{array}{c}\text { International Journal of Shipping and } \\
\text { Transport Logistics }\end{array}$ & $1756-6517$ & 107 & 1.319 \\
\hline- & Journal of Business Logistics & $0735-3766$ & 1433 & 2.020 \\
\hline A2 & Maritime Economics \& Logistics & $1479-2931$ & 327 & 0.833 \\
\hline- & INTERLENDING \& DOCUMENT SUPPLY & 0264-1615 & 65 & 0,168 \\
\hline - & $\begin{array}{c}\text { Journal of Purchasing and Supply } \\
\text { Management }\end{array}$ & $1478-4092$ & 492 & - \\
\hline A1 & Journal of Supply Chain Management & $1523-2409$ & 909 & - \\
\hline A2 & $\begin{array}{l}\text { SUPPLY CHAIN MANAGEMENT-AN } \\
\text { INTERNATIONAL JOURNAL }\end{array}$ & $1359-8546$ & 1873 & 3,451 \\
\hline B3 & $\begin{array}{c}\text { JOSCM. Journal of Operations and Supply } \\
\text { Chain Management }\end{array}$ & 1984-3046 & $1984-3046$ & - \\
\hline A2 & $\begin{array}{c}\text { International Journal of Services and } \\
\text { Operations Management }\end{array}$ & 1744-2389 & - & - \\
\hline B2 & $\begin{array}{c}\text { International Journal of Services } \\
\text { Operations and Informatic }\end{array}$ & $1741-5403$ & - & - \\
\hline B1 & $\begin{array}{l}\text { SPE Production \& Operations B1 } \\
\text { ENGENHARIAS III Atualizado }\end{array}$ & $1930-1855$ & - & - \\
\hline B4 & $\begin{array}{c}\text { International Journal of Advanced } \\
\text { Operations Management B4 }\end{array}$ & 1758-938X & - & - \\
\hline B1 & International Journal of Logistics & $1367-5567$ & - & - \\
\hline B1 & $\begin{array}{l}\text { International Journal of Logistics } \\
\text { Economics and Globalisation }\end{array}$ & 1741-5381 & - & - \\
\hline A2 & $\begin{array}{c}\text { International Journal of Logistics Systems } \\
\text { and Management (Print) }\end{array}$ & 1742-7967 & - & - \\
\hline A1 & $\begin{array}{l}\text { International Journal of Shipping and } \\
\text { Transport Logistics }\end{array}$ & $1756-6517$ & - & - \\
\hline B5 & $\begin{array}{c}\text { Journal of International Logistics and } \\
\text { Trade }\end{array}$ & $1738-2122$ & - & - \\
\hline A2 & Maritime Economics \& Logistics (Print) & $1479-2931$ & - & - \\
\hline A1 & $\begin{array}{c}\text { Transportation Research. Part E, Logistics } \\
\text { and Transportation Review }\end{array}$ & $1366-5545$ & - & - \\
\hline B3 & $\begin{array}{c}\begin{array}{c}\text { GEPROS. Gestão da Produção, Operações } \\
\text { e Sistemas }\end{array} \\
\end{array}$ & $1809-614 \mathrm{X}$ & - & - \\
\hline B3 & $\begin{array}{c}\text { GEPROS. Gestão da Produção, Operações } \\
\text { e Sistemas (Online) }\end{array}$ & $1984-2430$ & - & - \\
\hline B3 & $\begin{array}{c}\text { Revista de Gestão e Operações } \\
\text { Produtivas } \\
\end{array}$ & 2236-0301 & - & - \\
\hline
\end{tabular}

\subsection{Anexos II - Entrevistas 1 Eurochain}

Questionário 1 - Eurochain (supervisor e gerentes da operação)

\section{CARACTERIZAÇÃO (EMPRESA E ENTREVISTADO)}

\section{Qual o seu cargo e função?}

Responsável pelas operações

Há quantos anos você está na empresa? Há quantos anos nesta função?

Há mais de 5 anos.

Qual o número de funcionários?

Número de funcionários na operação de transportes farmacêutico é de 50 pessoas 


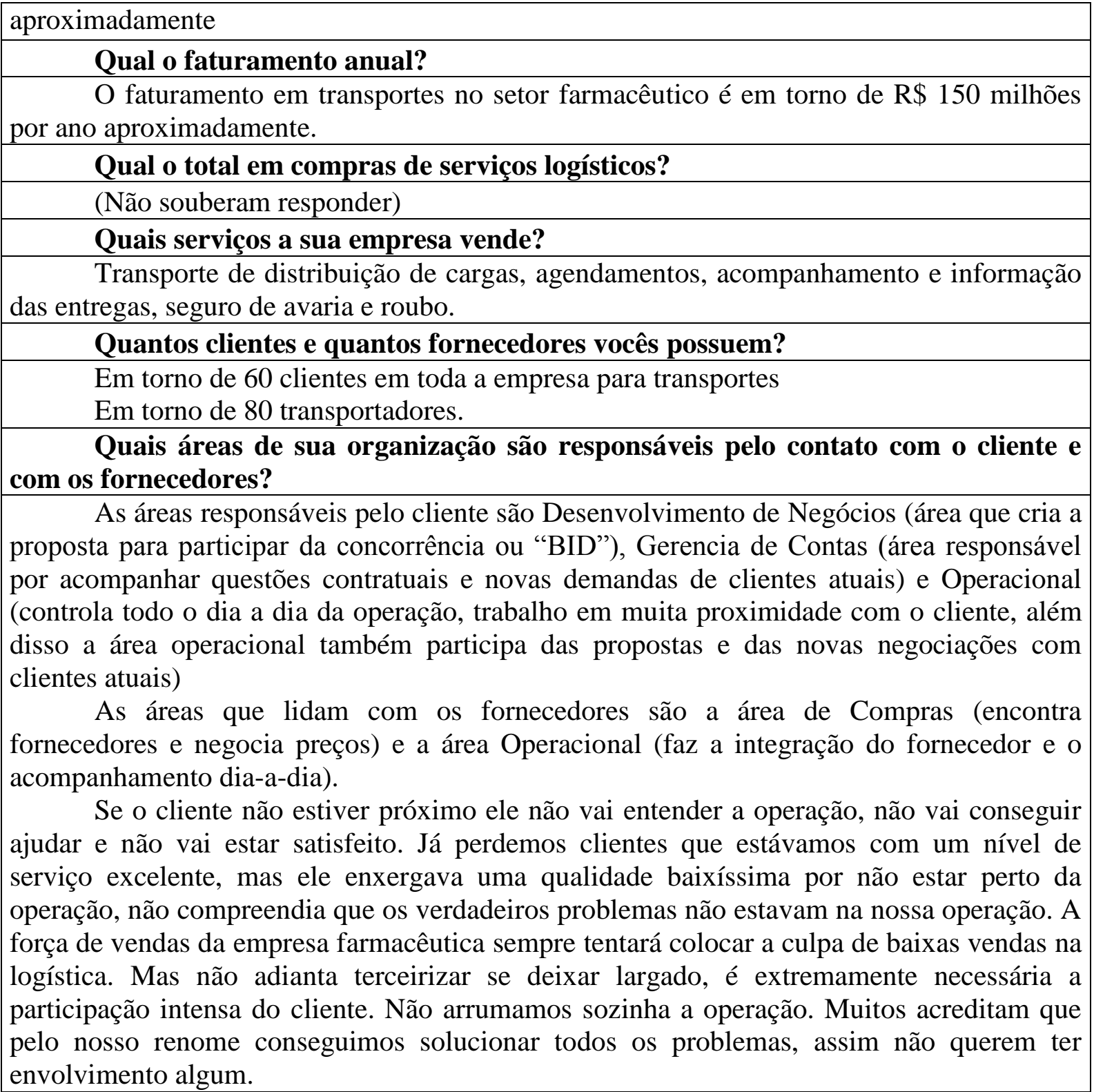


Por favor, me dê uma ideia geral da operação: pedido (faturamento), coleta, entrega. Frequências de coleta. Modais utilizados. E acompanhamento.

Nos é enviado o faturamento, nos montamos a programação de separação da carga, os transportadores são avisados, a coleta é feita, a carga é coletada e então é feito o agendamento com os clientes da Cialab.

\begin{tabular}{|c|}
\hline Perguntas sobre fornecedores \\
\hline Quantos são os fornecedores que atuam para este laboratório? \\
\hline 13 fornecedores - (me mostraram os fornecedores, mas não com os nomes reais) \\
\hline Quais são os fornecedores mais importantes ou de maior expressão? Por quê? \\
\hline $\begin{array}{l}\text { Existem vários importantes, dependendo da quantidade de entregas ou valor de } \\
\text { mercadoria, ou ainda para operações especiais }\end{array}$ \\
\hline $\begin{array}{l}\text { Há quanto tempo vocês trabalham com estes fornecedores? Como é o histórico } \\
\text { comercial e operacional? Eles apresentam boa performance? }\end{array}$ \\
\hline $\begin{array}{l}\text { Creio que em média os transportadores devem estar trabalhando conosco há } 6 \text { anos, } \\
\text { temos alguns com } 15 \text { anos. Nosso relacionamento é bom. Embora quando existem } \\
\text { problemas de falta, caso o transportador não justifique o custo de ressarcimento é dele. }\end{array}$ \\
\hline Perguntas sobre o cliente \\
\hline Qual o seu faturamento com o cliente em questão? \\
\hline $\begin{array}{l}\text { Esse cliente representa em torno de } 25 \% \text { do nosso faturamento do setor } \\
\text { Farmacêutico. }\end{array}$ \\
\hline Confirme o tipo de serviço que vocês prestam para este cliente? \\
\hline $\begin{array}{l}\text { Transporte de distribuição de cargas, agendamentos, acompanhamento e informação } \\
\text { das entregas, seguro de avaria e roubo. }\end{array}$ \\
\hline Qual a importância desta conta para vocês? Por quê? \\
\hline $\begin{array}{l}\text { É um cliente muito importante devido ao tamanho da conta, quando temos problemas } \\
\text { com este cliente uma grande número de pessoas na alta hierarquia é envolvida. }\end{array}$ \\
\hline $\begin{array}{l}\text { Há quanto tempo vocês possuem esta parceria? Como é o histórico comercial e } \\
\text { operacional? Vocês apresentam boa performance? }\end{array}$ \\
\hline $\begin{array}{l}\text { Tivemos os } 13 \text { primeiros anos tranquilos com ótimo nível de serviço e boa } \\
\text { lucratividade. Mas o cliente tem se tornado cada vez mais exigente, houve alterações de } \\
\text { contrato e níveis de serviço. Nossa relação com o cliente ficou mais próxima o primeiro } \\
\text { responsável pela operação no cliente montou uma sala no nosso prédio junto com uma } \\
\text { pessoa do exterior também. } \\
\text { Um exemplo de problema que não está na nossa responsabilidade, o destinatário não } \\
\text { recebe, pois diz que não existe pedido para aquela mercadoria, o cliente se não estiver } \\
\text { próximo irá entender que essa entrega é um atraso nosso, porém é falha de comunicação da } \\
\text { Empresa farmacêutica com o seu cliente. }\end{array}$ \\
\hline
\end{tabular}




\begin{tabular}{|c|}
\hline Está conta é lucrativa? \\
\hline Sim, é lucrativa. \\
\hline 1 - CENTRALIZAÇÃO \\
\hline SOBRE O FORNECEDOR \\
\hline Qual o seu contato com os fornecedores? \\
\hline $\begin{array}{l}\text { Meu contato é operacional e comercial, em algumas questões participo da negociação } \\
\text { de preços. }\end{array}$ \\
\hline $\begin{array}{l}\text { Quando existem alterações de procedimentos e padrões da operação, o } \\
\text { fornecedor é consultado? Vocês são consultados? (existe colaboração?) }\end{array}$ \\
\hline $\begin{array}{l}\text { O relacionamento não é "Top-Down", ditatorial, nos negociamos, tentamos, por } \\
\text { exemplo, em alguns casos colocar o pagamento atrelado ao retorno dos canhotos de entrega, } \\
\text { porém o transportador não aceitou e ficamos sem essa alteração do processo. Às vezes } \\
\text { damos uma forçada para chegar a um meio termo. }\end{array}$ \\
\hline $\begin{array}{l}\text { Como é feita a seleção de fornecedores? Quais são os critérios? (Preço, } \\
\text { performance, histórico) Qual tem maior influência? }\end{array}$ \\
\hline Esta pergunta quem deve responder é a equipe de compras. \\
\hline $\begin{array}{l}\text { Como é feito o acompanhamento da performance dos fornecedores? (o controle } \\
\text { é próximo? Relatórios e reuniões ?) }\end{array}$ \\
\hline $\begin{array}{l}\text { Temos um relatório com indicadores de apuração semanal e também temos uma } \\
\text { reunião mensal com cada um deles. }\end{array}$ \\
\hline $\begin{array}{l}\text { Em média, há quanto tempo vocês trabalham com cada fornecedor? (foco longo } \\
\text { ou curto prazo?) }\end{array}$ \\
\hline 6 anos \\
\hline Qual o principal motivo de troca de fornecedores? \\
\hline $\begin{array}{l}\text { Não cumprimento do nível de serviço ou então problemas na saúde financeiro do } \\
\text { transportador. Trabalhamos com alto valor de mercadoria, o risco é alto e o transportador } \\
\text { precisa estar apto a lidar com esse risco. }\end{array}$ \\
\hline $\begin{array}{l}\text { Vocês praticam multas e bônus por performance da operação? (maior controle, } \\
\text { reforço positivo e negativo) }\end{array}$ \\
\hline $\begin{array}{l}\text { Só existe bônus e multas entre a Empresa farmacêutica e nos operadores logísticos, } \\
\text { implantamos isso há } 2 \text { meses. Nós nunca recebemos bônus por algum fator interno do } \\
\text { Operador Logístico, só pagamos. }\end{array}$ \\
\hline $\begin{array}{l}\text { Em sua opinião, os seus fornecedores em média estão descontentes, satisfeitos ou } \\
\text { muito satisfeitos em prestar serviços para vocês? }\end{array}$ \\
\hline $\begin{array}{l}\text { Atualmente estão mais satisfeitos. Antigamente tínhamos problemas na separação da } \\
\text { carga e quando havia divergências que o transportador não conseguia justificar ele que tinha } \\
\text { que arcar com esses custos, como a mercadoria é de alto valor, isso era crítico com o } \\
\text { transportador. Hoje em dia este problema está bem menor. }\end{array}$ \\
\hline SOBRE O CLIENTE \\
\hline $\begin{array}{l}\text { Qual o seu contato com o Cliente? (contato comercial, entrevistado hábil para } \\
\text { responder perguntas) }\end{array}$ \\
\hline $\begin{array}{l}\text { Meu contato é o Operacional, não negocio preços, mas participo de novas propostas } \\
\text { na discussão técnica. }\end{array}$ \\
\hline $\begin{array}{l}\text { Como foi o processo de seleção que vocês participaram para ganhar a conta? } \\
\text { Qual foi o principal critério? (parceria internacional, experiência, qualidade ou preço) }\end{array}$ \\
\hline
\end{tabular}


Quando são necessárias mudanças na operação o cliente consulta vocês ou vocês consultam o cliente para desenvolver essas mudanças? (existe colaboração?)

Às vezes aparecem demandas que não temos como cumprir, nesse caso após justificarmos bem o cliente compreende os riscos e a inviabilidade, ou seja, temos um diálogo aberto.

Em sua opinião, vocês estão descontentes, satisfeitos ou muito satisfeitos em prestar serviços para este cliente?

Estamos muito satisfeitos, é uma operação de benchmarking, uma conta boa. Nesta operação desenvolvemos inovações, existe uma troca para os dois lados.

Os clientes aplicam multas e bônus por performance sobre vocês?

Sim, foi implementada há 2 meses.

\section{2 - FORMALIZAÇÃO}

Quais documentos regulamentam a operação?

(sugestões:

- Contrato com clientes

- Contrato com fornecedores

- SLA - Acordo de Nível de Serviço

- Relatório de acompanhamento de performance

- Ata de reunião com Cliente

- Ata de reunião com Transportador

- Tabela de preços

- Regras de Segurança

- Apólice de Seguro? DDR - Dispensa de Direito de Regresso?

- Lista de fornecedores)

Documentos apresentados pelo Gerente no dia 15-07-14 das 16:00 às 17:30.

Evidência documental:

- $\quad$ PGR (Plano de Gerenciamento de Risco) da Eurochain: trata de diversos assuntos relacionados a como operar, por exemplo, perfil do motorista

\begin{tabular}{|c|c|c|c|c|c|c|c|c|c|}
\hline $\begin{array}{c}\text { Casos } \\
\text { específicos } \\
\text { tratados } \\
\end{array}$ & Origem & Destino & $\begin{array}{c}\text { Limite de valor } \\
\text { de carga por } \\
\text { veículo }\end{array}$ & Escolta & Rastreamento & $\begin{array}{l}\text { Período de } \\
\text { atualização }\end{array}$ & \begin{tabular}{|c|}
$\begin{array}{c}\text { Equipamentos de } \\
\text { seguranças } \\
\text { necessários }\end{array}$ \\
\end{tabular} & $\begin{array}{l}\text { Restrição de } \\
\text { horários }\end{array}$ & $\begin{array}{c}\text { Atendimento } \\
\text { permitido }\end{array}$ \\
\hline inbound & Laboratorio & $\begin{array}{l}\text { Centro de } \\
\text { Distribuição }\end{array}$ & $\begin{array}{c}\text { Valor limite } \mathrm{R} \$ \\
1.000 .000,00\end{array}$ & $\begin{array}{l}\text { para valores acima } \\
\text { de } R \$ 300.000,00\end{array}$ & $\begin{array}{c}\text { Especificação } \\
\text { da marca do } \\
\text { rastreador }\end{array}$ & $\begin{array}{l}\text { as informações } \\
\text { deve ser } \\
\text { atualizadas de } 5 \\
\text { em } 5 \text { minutos }\end{array}$ & $\begin{array}{c}\text { travas no baú, } \\
\text { sensores, } \\
\text { rastreador e outros } \\
\text { equipamentos de } \\
\text { segurança }\end{array}$ & $\begin{array}{c}\text { não é permitido o } \\
\text { trânsito de carga } \\
\text { das } 23 \mathrm{hr} \text { até às } \\
06 \mathrm{hr}\end{array}$ & $\begin{array}{c}\text { Tanto com Frota } \\
\text { Própria quanto } \\
\text { prestador } \\
\text { terceirizado }\end{array}$ \\
\hline $\begin{array}{l}\text { Produtos } \\
\text { Perecíveis }\end{array}$ & - & - & - & - & - & - & - & - & - \\
\hline amostra gratis & - & - & - & - & - & - & - & - & - \\
\hline \begin{tabular}{|l|} 
Promocionais \\
\end{tabular} & - & - & - & - & - & - & - & - & - \\
\hline Devolução & - & - & - & - & - & - & - & - & - \\
\hline coleta & - & - & - & - & - & - & - & - & - \\
\hline Transferencia & - & - & - & - & - & - & - & - & - \\
\hline $\begin{array}{c}\text { Distruibuição } \\
\text { de cargas em } \\
\text { SP, RJ, GO, DF e } \\
\text { ES. } \\
\end{array}$ & - & - & - & - & - & - & - & - & - \\
\hline
\end{tabular}

- $\quad$ Apresentação para cliente da Reunião com Cialab

- Apresentação para Reunião Mensal entre Eurochain e fornecedores, a apresentação tratava dos seguintes tópicos:

o Performance de entregas no prazo (meta de 98\%) variava em torno desta meta $97 \%$ ou $99 \%$, esta performance era apresentada por Estado e por cliente para poder avaliar se havia alguma performance muito fora da media.

o Performance de retorno de informação da transportadora para o 
Operador Logístico, existe um prazo acordado para a transportadora passar informações de confirmações das entregas

o Coletas de cargas com problema - existe uma lista de cargas que depois de entregues devem retornar para o laboratório devido a problemas encontrados, assim essas operações são acompanhadas separadamente na reunião.

o Performance de retorno de canhotos da nota fiscal. O retorno do Canhoto da Nota Fiscal é uma exigência do Operador Logístico, caso o destinatário reclame não ter recebido a carga a prova de que a carga foi entregue é o canhoto, se este não existir o Operador Logístico deverá ressarcir o cliente e ser ressarcido pelo transportador arcará com o prejuízo.

o Sinistro - acompanhamento dos pagamentos das cargas avariadas ou perdidas que devem ser ressarcidas ao operador logístico. Caso haja uma reclamação e o transportador não consiga provar que a culpa não foi dele, o transportador deverá ressarcir o Operador Logístico.

- Ata com acompanhamento de ações corretivas - lista de problemas que devem ser resolvidos pelo transportador e os prazos acordados para a implantação das soluções, por exemplo, aumentar o número de atendentes no call-center, ou melhorar a performance no interior do Espírito Santo.

- $\quad$ E-mail com a agenda da reunião mensal entre Cialab e Eurochain:

o Definição dos horários de reuniões diárias (em um a cada 3 meses quando existe o fechamento trimestral da Empresa farmacêutica é realizado reuniões por telefone diárias sobre o andamento da operação)

o $\quad$ Discussão sobre operação de carros dedicados

o Manuseio da Carga

o Problemas operacionais

- $\quad$ Planilha de orientação para o cliente emitir Notas Fiscais no tempo correto para se atingir os prazos de entrega demandados. (É um documento da Eurochain para orientar a Cialab sobre como e quando deve faturar as suas vendas)

pontos:

o Performance de entregas no prazo e performance de avarias, causas de baixa performance e identificação dos responsáveis.

o Impactos da Copa do Mundo

o Ressarcimentos a serem feitos a Indústria Farmacêutica

o Melhorias na Qualidade

o Acompanhamento de modalidade de entregas específicas para pessoas

físicas

o Agendamentos - tratamento especial para os destinatários que precisam ter dia e horário da entrega agendada, mais de $70 \%$ dos clientes trabalham com este procedimento

cidade de destino

Tabela de Prazos de entrega: tabela com dias para entrega para cada região ou

- Tabela de preço para modal aéreo: tabela de preços que considera a variação de peso, destino e valor de mercadoria.

As regras / normas de funcionamento com o seu fornecedor são explícitas, estão escritas? É do conhecimento de todos os envolvidos?

Existem tabelas de preço, com prazos acordados, também temos o Plano de Gerenciamento de Risco a ser seguido e fazemos as reuniões. 


\section{3 - COMPLEXIDADE}

(Entender com o entrevistado a localização da Indústria, Centros de Distribuição, Operador Logístico e Principais Transportadores)

Temos 3 centros de distribuição do setor farmacêutico no Brasil, mas os produtos Cialab estão todos aqui neste Centro de Distribuição de São Paulo.

(Escolher uma localização com volume médio e de importância para se fazer o mapeamento até os últimos níveis de fornecedores)

(Os entrevistados me passaram a lista de fornecedores, não com os nomes reais, esta foi representada na figura onde estão mapeados os fornecedores)

\section{4 - INTEGRAÇÃO}

Existe algum esforço entre as empresas da cadeia para a criação de colaboração? (Colaboração é a criação de objetivos em comum e confiança)(COUGHLAN et. al. 2003)

Estamos muito satisfeitos, é uma operação de benchmarking, uma conta boa. Nesta operação desenvolvemos inovações, existe uma troca para os dois lados. (Durante a entrevista o entrevistado apontou situações onde Cialab trabalha de forma próxima com eles, inclusive, em uma ocasião a gerencia da Cialab ficou alocada no mesmo prédio da Eurochain. Isso mostra uma visão de trabalho em conjunto, entretanto este evento teve como foco a solução de problemas operacionais e não um trabalho em conjunto pensando no ganho conjunto, conforme proposto pela teoria) 


\section{OUTRAS INFORMAÇÕES}

- A distribuição de cargas por destinatários está da seguinte forma:

- $-70 \%$ com grandes distribuidores que redistribuem para as drogarias

- $-30 \%$ Hospitais, clínicas, drogarias e governo

- Entregamos nos clientes finais nos casos de pacientes com problemas crônicos e linhas especiais de medicamentos para algumas pessoas físicas que participaram nos primeiros testes.

- Trabalhamos com alto valor de mercadoria, o risco é alto e o transportador precisa estar apto a lidar com esse risco.

- Alguns clientes já pediram para colocar mais de $\mathrm{R} \$ 5$ milhões em carga em único veículo.

- O distribuidor, cliente da indústria, tem muita força, a opinião dele é a que vai pesar para a indústria. Um cliente me disse que os indicadores não têm importância para ele e sim o que o cliente final dele está pensando.

- O distribuidor é o elo forte da cadeia, ele decide se a carga pode ser misturada ou não, ele decide se retém o comprovante ou não, isso não é correto, o certo é que todos os comprovantes sejam entregues no ato, mas alguns distribuidores não devolvem assim o transportador e nós não temos como comprovar que a carga foi entregue, mas não conseguimos mudar isso. Melhoramos algumas dificuldades como o alinhamento dos prazos, o prazo que o cliente entendia era diferente do nosso. (Eles explicaram que em alguns casos o cliente começava a contar o prazo de entrega a partir do momento que fechava a negociação, mas não considerava outros prazos como de sistema, aprovação do pedido, descontos, separação da carga e agendamentos)

- O cliente Cialab possui seguradora e a Eurochain também possui a sua, a Eurcochain é responsável por pequenos furtos e a Cialab pelos outros riscos.

- A Eurochain possui, além disso, uma empresa gerenciadora de Risco que é responsável pelo acompanhamento dos veículos, monitoramentos e rastreamentos. Ele não sabe dizer se a Cialab também possui uma gerenciadora de risco, mas ele acredita que sim.

- A Indústria Farmacêutica em questão emite em Média de 10 mil NF por mês.

- O operador Logístico não influencia na escolha de fornecedores de seus fornecedores, entretanto influenciam troca de fornecedor, por exemplo, eles descobrem que o parceiro de algum estado está causando problemas recorrentes e estes não solucionam eles pedem para trocar de fornecedor.

- O operador logístico não interfere na escolha das companhias aéreas utilizadas por seus fornecedores.

- O total de carga para a região sul e sudeste é equivalente a $25 \%$ do total de carga Cialab no país.

- O total levado pelo transportador Sul Deste Cargo é de 10\% deste total, ou seja, 2,5\% do total Cialab.

- O total de carga aérea da Cialab representa uns 20\% do total da carga. Desses $20 \%$ desses $90 \%$ são transportados pela Air Cargo, ou seja, a Air Cargo transporta em 
torno de $18 \%$ de toda carga Cialab.

- Total de 10 mil Nfs / mês da Cialab

- Se o cliente não estiver próximo da operação, se ele não participar do processo ele nunca vai estar satisfeito, ele nunca vai entender a operação, ele vai achar que o nível de serviço está em $58 \%$, mas a realidade é $98 \%$, ele não vai enxergar quais são os problemas da empresa dele mesmo. O desenvolvimento do serviço tem que ser feito a 4 mãos, não adianta ele terceirizar e largar, eu não arrumo tudo sozinho. Tem problemas que são do destinatário e não é erro nosso, por exemplo, às vezes o sistema do destinatário não reconhece a nota fiscal.

\section{-------Visita ao Centro de Distribuição da Eurochain}

- 12 clientes no armazém. $100 \%$ climatizado.

- Mais de mil posições pallets. posições de 0 a 8 graus.

- Trabalhamos em 3 turnos.

- As cargas perecíveis saem às 2 hr da manhã e ás 6 hrs, elas são enviadas pelo aéreo para fora do estado de São Paulo.

- Muitos desses 12 clientes vendem para os mesmos destinatários.

- Existem as câmaras refrigeradas de gelo.

- Áreas separadas para medicamentos controlados e de alto valor.

- Fazemos customização de produtos com etiquetas, por exemplo, "venda proibida".

- (Pude observar o nome dos transportadores que coletam, cada um possui um espaço para fazer a conferência conforme haviam me informado).

- O controle da operação é feito de forma digital em grandes telas de LCD, com indicadores de cargas a serem separadas e status dessa separação. 
Questionário sobre autonomia para execução do serviç̧o

\begin{tabular}{|c|c|c|c|c|c|c|}
\hline \multirow{2}{*}{ Elementos do Serviço de Transportes } & \multicolumn{6}{|c|}{ Qual empresa é responsável por escolher como os elementos do serviço serão desenvolvidos e/ou executados? } \\
\hline & Indústria Farmacêutica & Operador Logístico & $\begin{array}{c}\text { Transpotador coleta e 19 } \\
\text { Transferência }\end{array}$ & Transportador Entrega Final & $\begin{array}{c}\text { Cliente final(distribuidores, } \\
\text { drogarias, governo, pessoas } \\
\text { fisicas) }\end{array}$ & Outros (Governo, Anvisa) \\
\hline 1 Veículo (marca, ano, modelo, manutenção) & - & $\begin{array}{l}\mathbf{X} \text { - Operador pede no } \\
\text { contrato uma idade média da } \\
\text { frota }\end{array}$ & $\begin{array}{l}\mathbf{X} \text {-todas as outras } \\
\text { responsabilidades é do } \\
\text { transportador }\end{array}$ & - & - & - \\
\hline 2 Horário de Coleta & $\cdot$ & $\begin{array}{l}X \text { - O operador define e } \\
\text { transportador atende }\end{array}$ & - & - & - & - \\
\hline 3 Horário de Entrega & $\cdot$ & $\cdot$ & - & - & $\begin{array}{l}\text { X-O cliente final é quem } \\
\text { escolhe }\end{array}$ & $\cdot$ \\
\hline 4 Horário de viagem/manuseio & $\begin{array}{l}\text { X-Seguradoura da Indústria } \\
\text { Farmacêutica }\end{array}$ & $\begin{array}{l}\text { X-Seguradoura do Operador } \\
\text { Logistico }\end{array}$ & - & - & - & - \\
\hline 5 Contratação de fornecedores na ponta & - & $\begin{array}{c}\text { X-O operador logístico pode } \\
\text { influenciar na troca de algum } \\
\text { fornecedor caso este esteja com } \\
\text { baixa performance }\end{array}$ & $\begin{array}{c}\mathrm{x} \text { - Responsabilidade total do } \\
\text { transportador }\end{array}$ & - & - & - \\
\hline \begin{tabular}{|l|l|}
6 & $\begin{array}{l}\text { Preparação da carga no veículo (paletização, } \\
\text { mistura de cargas diferentes e outross?? }\end{array}$ \\
\end{tabular} & $\begin{array}{c}\mathrm{X} \text { - Seguradoura da Indústria } \\
\text { Farmacêutica determina quais } \\
\text { cargas podem ser misturadas no } \\
\text { veiculo }\end{array}$ & $\begin{array}{c}\text { X-Seguradoura do Operador } \\
\text { Logístico determina quais cargas } \\
\text { podem ser misturadas no } \\
\text { veículo }\end{array}$ & 15 & - & $\begin{array}{l}\text { X- Determina como irá receber } \\
\text { a carga, por exemplo: altura do } \\
\text { pallete e produtos por pallete }\end{array}$ & $\begin{array}{l}\text { X-Anvisa não permite que } \\
\text { medicamentos sejam misturado } \\
\text { a alguns outros tipos de cargas. }\end{array}$ \\
\hline $\begin{array}{l}77 \begin{array}{l}\text { Contratacăão dos motoristas dos seus } \\
\text { fornecedores diretos (perfil) }\end{array}\end{array}$ & - & $\begin{array}{c}\text { X-Seguradoura do Operador } \\
\text { Logistico determina perfil dos } \\
\text { motoristas } \\
\end{array}$ & \begin{tabular}{|c|}
$\begin{array}{c}\text { X- Respeitando as condicōes da } \\
\text { seguradoura, o transportador } \\
\text { escolhe livremente seus } \\
\text { motoristas }\end{array}$ \\
\end{tabular} & - & - & - \\
\hline $8 \begin{array}{l}\text { Contratação dos motoristas dos seus } \\
\text { fornecedores Indiretos }\end{array}$ & $\cdot$ & - & - & $\begin{array}{l}X \text {-Responsabilidade da } \\
\text { transportadora quarterizada }\end{array}$ & - & $\cdot$ \\
\hline $9 \begin{array}{l}\begin{array}{l}\text { Equipe de atendimento do Operador Logístico } \\
\text { (quantidade de funcinários, perfil dos } \\
\text { funcionários contratados, treinamento, horários } \\
\text { de atendimento) }\end{array} \\
\end{array}$ & - & $\begin{array}{l}\text { X-O operador logístico que } \\
\text { define seu próprio time. }\end{array}$ & - & - & - & - \\
\hline 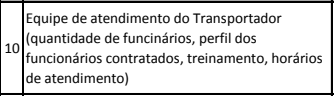 & - & $\begin{array}{l}\text { X-O operador logistico pode } \\
\text { influenciar na quantidade de } \\
\text { pessoas e horários de trabalho }\end{array}$ & $\begin{array}{l}\text { X-O transportador contrata } \\
\text { livremente o seu time }\end{array}$ & - & - & - \\
\hline $11 \mid \begin{array}{l}\text { Organização e frequencia das reuniöes de } \\
\text { acompanhamento da performance da operação }\end{array}$ & - & $\begin{array}{l}X-O \text { operador que define as } \\
\text { datas das reuniões com os } \\
\text { transportadores }\end{array}$ & - & - & - & - \\
\hline 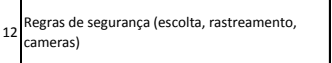 & $\begin{array}{l}\text { x- Seguradoura da Indústria } \\
\text { Farmacêutica }\end{array}$ & $\begin{array}{l}\text { X-Seguradoura do Operador } \\
\text { Logistico }\end{array}$ & - & - & - & - \\
\hline 13 Regras de Operação (Anvisa ou outros) & - & - & - & - & - & $\begin{array}{l}\text { X- Não permite a mistura de } \\
\text { cargas, tabela de } \\
\text { compatibilidade de cargas }\end{array}$ \\
\hline $14 \begin{array}{l}\text { Preço de compra com fornecedores (alguém } \\
\text { além do cliente do fornecedor interferem na } \\
\text { negociação??) }\end{array}$ & $\begin{array}{c}\mathrm{X}-\mathrm{O} \text { preço é definido } \\
\text { exclusivamente por negociação } \\
\text { entre Indústria e operador }\end{array}$ & $\begin{array}{c}\text { X-O preço é definido } \\
\text { exclusivamente por negociação } \\
\text { entre Indústria e operador }\end{array}$ & 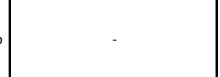 & - & - & - \\
\hline 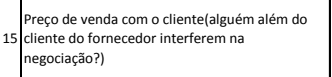 & - & $\begin{array}{l}\text { X-O o preço é definido } \\
\text { exclusivamente por negociação } \\
\text { entre operador e transportador }\end{array}$ & $\begin{array}{c}\text { X-O preço é definido } \\
\text { exclusivamente por negociação } \\
\text { entre operador e transportador }\end{array}$ & - & . & - \\
\hline 16 lo $\begin{array}{l}\text { Outros (procedimentos do time interno } \\
\text { operador): }\end{array}$ & $\cdot$ & $\cdot$ & $\cdot$ & $\cdot$ & $\cdot$ & $\cdot$ \\
\hline & & Qual empresa é respor & nsável por escolher como os eleme & nentos do serviço serão desenvol & Ividos e/ou executados? & \\
\hline Eurochain & Indústria Farmacêutica & Operador Logístico & $\begin{array}{l}\text { Transpotador coleta e 1: } \\
\text { Transferência }\end{array}$ & Transportador Entrega final & $\begin{array}{l}\text { Cliente final(distribuidores, } \\
\text { drogarias, governo, pessoas } \\
\text { fisicas) }\end{array}$ & Outros (Governo, Anvisa) \\
\hline Quantidade de Elementos & 4 & 12 & 5 & 1 & 2 & 2 \\
\hline Quais elementos & \begin{tabular}{|l|}
$\begin{array}{l}\text { Horarios de viagem, regras de } \\
\text { gerenciamento de risco e } \\
\text { preparaçã oda carga }\end{array}$ \\
\end{tabular} & $\begin{array}{l}\text { Horarios de viagem, regras de } \\
\text { gerenciamento de risco } \\
\text { preparaçă oda a arga, veiculo, } \\
\text { contratação de fornecedor, } \\
\text { perfil do motorisa, time de } \\
\text { atendimento seu e do } \\
\text { transportador e reuniőes de } \\
\text { acompanhamento }\end{array}$ & $\begin{array}{l}\text { Veículo, motoristas, } \\
\text { fornecedores e time de } \\
\text { atendimento }\end{array}$ & Motorista & $\begin{array}{l}\text { horário de entrega e preparaçã } \\
\text { oda carga }\end{array}$ & Preparação de carga \\
\hline
\end{tabular}

Comentário: 


\subsection{Anexos III - Entrevistas 2 Eurochain II}

Questionário 2 - Eurochain (Gerente de Compras)

\begin{tabular}{|c|c|}
\hline & CARACTERIZAÇÃO (EMPRESA E ENTREVISTADO) \\
\hline & Qual o seu cargo e função? \\
\hline & Operações e Compras \\
\hline & Há quantos anos você está na empresa? Há quantos anos nesta função? \\
\hline & Há mais de 5 anos. \\
\hline & Qual o número de funcionários? \\
\hline & Mais de 5000 no Brasil \\
\hline & Qual o faturamento anual? \\
\hline & Só em transportes temos em torno de $\mathrm{R} \$ 300$ milhões \\
\hline & Qual o total em compras de serviços logísticos? \\
\hline & Mais de $\mathrm{R} \$ 100$ milhões \\
\hline & Quais serviços a sua empresa vende? \\
\hline $\begin{array}{l}\text { aéreo e } \\
\text { e indica } \\
\text { da nota } \\
\text { matéria }\end{array}$ & $\begin{array}{l}\text { Armazenagem, transportes: aéreo, rodoviário, lotação, fracionado, Milk-run, dedicado, } \\
\text { expresso, fretamento de aeronave, gerenciamento do transporte(sistema de informações } \\
\text { cadores gerenciais), rastreamento da carga, gerenciamento de risco, controle de canhotos } \\
\text { a fiscal, projetos de otimização, como se fosse um consultoria, seguro e recebimento de } \\
\text { a prima. }\end{array}$ \\
\hline & Quantos clientes e quantos fornecedores vocês possuem? \\
\hline & Em torno de 50 clientes e 80 transportadores diretamente contratados \\
\hline os forn & $\begin{array}{l}\text { Quais áreas de sua organização são responsáveis pelo contato com o cliente e com } \\
\text { necedores? }\end{array}$ \\
\hline $\begin{array}{l}\text { fazem } \\
\text { operaci }\end{array}$ & $\begin{array}{l}\text { Com o cliente temos o seguinte:Temos uma área de desenvolvimento de negócios que } \\
\text { contato com o cliente para manutenção da conta. É um contato dividido entre } \\
\text { ional e comercial. }\end{array}$ \\
\hline
\end{tabular}

Por favor, me dê uma ideia geral da operação: pedido (faturamento), coleta, entrega. Frequências de coleta. Modais utilizados. $E$ acompanhamento.

$\mathrm{Na}$ distribuição já temos alguns horários pré-combinados com os transportadores para eles fazerem as coletas, mas antes passamos a programação para eles determinarem o veículo, escolta e outros preparativos, depois eles seguem as informações de entrega para concluírem o serviço.

\section{Perguntas sobre fornecedores}

Quantos são os fornecedores que atuam para esta indústria farmacêutica?

- (não sabia responder)

Quais são os fornecedores mais importantes ou de maior expressão? Por quê?

Cada um tem sua importância.

Há quanto tempo vocês trabalham com estes fornecedores? Como é o histórico comercial e operacional? Eles apresentam boa performance?

Sim, temos uma constância no setor, não mudamos muito de fornecedores. Temos alguns já trabalhando conosco há mais de 10 anos, mas a média deve estar entre 4 a 5 anos conosco. É muito difícil lidar com essas empresas, mas nos sabemos como lidar com eles, eles são emocionais, assim, eles precisam ter muita confiança na gente, eles vão ver o histórico que tem conosco, às vezes são pouco profissionais (creio que ele estava falando sobre o 


\begin{tabular}{|l|}
\hline $\begin{array}{l}\text { mercado em geral e não sobre as empresas do farmacêutico), eles precisam pensar "confio em } \\
\text { você”. }\end{array}$ \\
\hline Perguntas sobre o cliente \\
\hline Qual o seu faturamento com o cliente em questão? \\
A Cialab deve representar em torno de $25 \%$ de todo o nosso faturamento do setor \\
farmacêutico. Esse setor dentro da área de transportes corresponde a $25 \%$ do total. (podemos \\
dizer que a Cialab corresponde a 6\% do faturamento total da área de transportes)
\end{tabular}


Como é feita a seleção de fornecedores? Quais são os critérios? (Preço, performance, histórico) Qual tem maior influência?

Checamos diversos critérios como: Estrutura Física prédios e veículos, também conferimos a saúde financeira da empresa, pois eles carregam carga de alto valor, a organização interna deles com processos e procedimentos, capilaridade ou o número de rotas, parceiros e opções que eles possuem para chegar nos locais mais distantes. Requerimentos legais como licenças de funcionamento da vigilância sanitária, bombeiros, exército, gerenciamento de risco Anvisa e outros. Conhece o setor que vai atuar e atende nossas metas de preço.

Como é feito o acompanhamento da performance dos fornecedores? (o controle é próximo? Relatórios e reuniões ?)

A operação acompanha no dia a dia, além disso, existem reuniões mensais. Temos relatórios semanais e se precisar diários sobre como está a operação. ou curto prazo?)

No setor farmacêutico temos em média 4 a 5 anos.

Qual o principal motivo de troca de fornecedores?

Nível de serviço ou Custo. Às vezes o transportador pede reajuste de $30 \%$ ou ameaça de ir embora. Quando o problema é nível de serviço a última opção é cortar o fornecedor, tentamos fortemente desenvolvê-lo. É muito complexo trocar de fornecedores, pois sempre temos um grande trabalho de transferência de conhecimento para o fornecedor, atualmente o mercado está escasso de bons fornecedores, não se encontra fornecedores bem preparados.

Vocês praticam multas e bônus por performance da operação? (maior controle, reforço positivo e negativo)

Sim, mas não em todos os casos, só para fornecedores estratégicos que precisam de um controle mais próximo, aqueles com volumes altos ou em operações essenciais como os que fazem transferência para os Cross-dockings.

Em sua opinião, os seus fornecedores em média estão descontentes, satisfeitos ou muito satisfeitos em prestar serviços para vocês?

Creio que estejam satisfeitos.

\section{SOBRE O CLIENTE}

Qual o seu contato com o Cliente? (contato comercial, entrevistado hábil para responder perguntas)

Não tenho contato com a Cialab.

Como foi o processo de seleção que vocês participaram para ganhar a conta? Qual foi o principal critério? (parceria internacional, experiência, qualidade ou preço)

Algo que pesa muito é a presença global da Eurochain, pois embora cada país negocie seu contrato existe muita força na matriz das empresas, ambas estão no exterior com contas globais.

Quando são necessárias mudanças na operação o cliente consulta vocês ou vocês consultam o cliente para desenvolver essas mudanças? (existe colaboração?)

Eles até abrem para discutir, mas geralmente assumem que iremos conseguir e pronto, eles pensam "vocês são a Eurochain, vocês vão dar um jeito e conseguir", é isso que eles assumem. Quando nos fazemos alguma alteração damos treinamento para os fornecedores, mas o cliente já assume que conseguiremos. 
Em sua opinião, vocês estão descontentes, satisfeitos ou muito satisfeitos em prestar serviços para este cliente?

Sim, é uma boa conta.

Os clientes aplicam multas e bônus por performance sobre vocês?

Sim. (não entrou em detalhes)

\section{2 - FORMALIZAÇÃO}

Quais documentos regulamentam a operação?

(sugestões:

- Contrato com clientes

- Contrato com fornecedores

- SLA - Acordo de Nível de Serviço

- Relatório de acompanhamento de performance

- Ata de reunião com Cliente

- Ata de reunião com Transportador

- Tabela de preços

- Regras de Segurança

- Apólice de Seguro? DDR - Dispensa de Direito de Regresso?

- Lista de fornecedores)

(O entrevistado pediu para que fossem coletadas as evidências junto ao time operacional)

As regras / normas de funcionamento com o seu fornecedor são explícitas, estão escritas? É do conhecimento de todos os envolvidos?

Quando os principais clientes do laboratório fazem alguma alteração, muitas vezes não sabemos de nada, ficamos sabendo só que a carga não foi recebida ou sabemos pela reclamação da Cialab.

\section{3 - COMPLEXIDADE}

(Entender com o entrevistado a localização da Indústria, Centros de Distribuição, Operador Logístico e Principais Transportadores)

Todos, tanto fábricas, centro de distribuição e unidades dos transportadores ficam dentro da Grande São Paulo.

(Escolher uma localização com volume médio e de importância para se fazer o mapeamento até os últimos níveis de fornecedores)

Falar com gerente operacional.

\section{4 - INTEGRAÇÃO}

Existe algum esforço entre as empresas da cadeia para a criação de colaboração? (Colaboração é a criação de objetivos em comum e confiança)(COUGHLAN et. al. 2003)

Existem esforços isolados, mas nada que atinja toda a cadeia.

- A cadeia não conversa, não existe um dialogo geral entre Indústria, Operador logístico e destinatários 


\section{OUTRAS INFORMAÇÕES}

- Os laboratórios têm suas próprias seguradoras e seus planos de gerenciamento de risco, cada um deles entra em conflito com os outros, isso limita muito a operação, pois não posso colocar carga de diferentes concorrentes no mesmo veículo, ás vezes tem diversas entregas de vários laboratórios no mesmo destinatário na mesma semana ou mesmo dia, mas precisamos enviar dezenas de veículos ao invés de só um, pois existem regras que nos limitam.

- Contra o risco de roubo são contratadas empresas especializadas em auxiliar no gerenciamento de risco, são as gerenciadoras de risco.

- Sobre as principais dificuldades de nossa operação destaco:

- - Complexidade no recebimento da carga dos clientes Distribuidores, Farmácias, e Hospitais - os mais difíceis determinam como iremos trabalhar, horários e como a carga deverá estar (janela que podemos entregar, tipo de veículo, carga separada por produto, ou por nota fiscal, altura do pallet)

o - Regras de gerenciamento de risco: impactam no nosso nível de serviço; definem o valor máximo, rastreamento, escolta, tela de proteção, todos esses requerimentos nos restringem a poucos fornecedores que conseguem nos atender de forma adequada.

- - A indústria é quem possui poder para ligar as partes e fazer comunicação, mas atualmente só passamos informação. Até temos abertura para conversar, mas se seremos ouvidos é outra história. 
Questionário sobre autonomia para execução do serviço

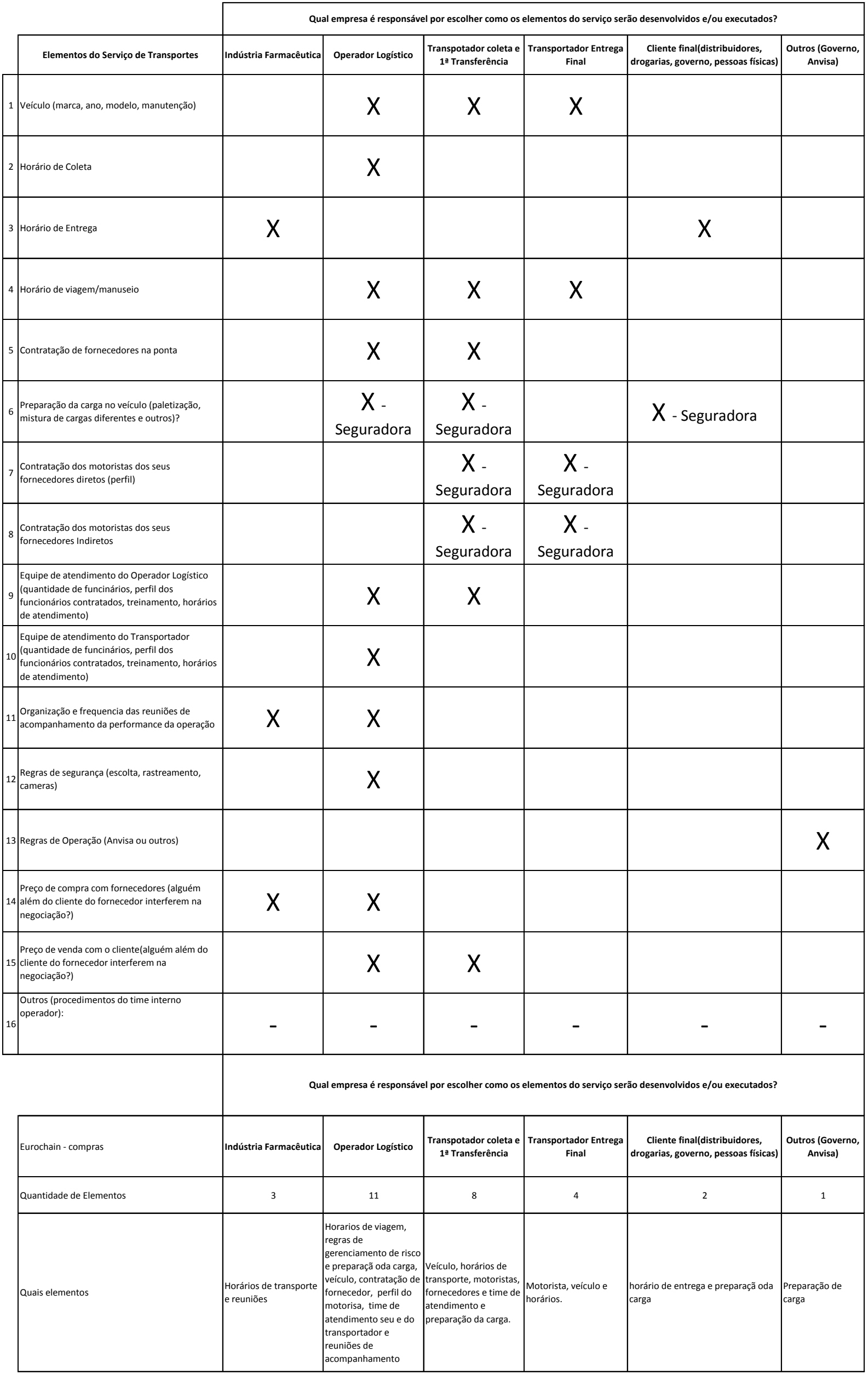




\subsection{Anexos IV - Entrevistas 3 Cialab}

Questionário - Cialab

\begin{tabular}{|l|}
\hline CARACTERIZAÇÃO (EMPRESA E ENTREVISTADO) \\
\hline Qual o seu cargo e função? \\
\hline Responsável por operações no Brasil \\
\hline Há quantos anos você está na empresa? Há quantos anos nesta função? \\
\hline \\
\hline Qual o número de funcionários? \\
\hline No mundo mais de 50 mil. \\
\hline Qual o faturamento anual? \\
\hline Mais de R\$ 1 bilhões por ano no Brasil \\
\hline Qual o total em compras de seviços logísticos? \\
\hline Em compras de serviços logísticos gastamos mais de R\$10 milhões por ano. \\
\hline Quais serviços a sua empresa vende? \\
\hline Não vendemos serviços, mas medicamentos. (no site da empresa aparecem mais de \\
\hline
\end{tabular}
200 bulas).

Com relação a serviços, nós só compramos, nos compramos dos operadores a armazenagem, transporte e a customização dos produtos sem abrir a embalagem, (etiquetar e marcar as embalagens ou montar kits.)

\section{Quantos clientes e quantos fornecedores vocês possuem?}

Temos contratados 2 operadores logísticos a Eurochain e outra empresa. Mas a Eurochain é responsável por todo o nosso transporte de produtos acabados que são vendidos. O outro operador só cuida de medicamentos de amostra grátis que é um volume muito menor, é importante, mas não é como as nossas vendas.

Quais áreas de sua organização são responsáveis pelo contato com o cliente e com os fornecedores?

O contato com os clientes é feito pela área comercial.

Com o fornecedor temos a área de compras e operacional. (a equipe de compras era extremamente recente e não pode participar da pesquisa)

Por favor, me dê uma ideia geral da operação: pedido (faturamento), coleta, entrega. Frequências de coleta. Modais utilizados. E acompanhamento.

A venda é fechada e a Nota Fiscal emitida, em seguida a Eurochain faz a separação e deixa a carga pronta no dia seguinte para ser embarcada, a equipe de transportes da Eurochain segue como responsável assim que a carga está com os transportadores. Uma vez que nosso comercial coloca a o pedido de faturamento, a Eurochain tem 1 dia para separar a carga e deixá-la pronta para o embarque.

\begin{tabular}{|l|}
\hline Perguntas sobre fornecedores \\
\hline Quantos são os fornecedores que atuam para este laboratório? \\
\hline 2 fornecedores diretos o principal deles é a Eurochain \\
\hline Quais são os fornecedores mais importantes ou de maior expressão? Por quê? \\
\hline A Eurochain pelo volume dela \\
\hline $\begin{array}{l}\text { Há quanto tempo vocês trabalham com estes fornecedores? Como é o histórico } \\
\text { comercial e operacional? Eles apresentam boa performance? }\end{array}$ \\
\hline
\end{tabular}




\begin{tabular}{|c|c|}
\hline & 寸іla \\
\hline & Perguntas sobre o cliente \\
\hline & Qual o seu faturamento com o cliente em o \\
\hline & (pergunta não se aplica a indústria) \\
\hline & Confirme o tipo de serviço que vocês prestam para este cliente? \\
\hline & (não se aplica - vendem medicamentos) \\
\hline & Qual a importância desta conta para vocês? Por quê? \\
\hline país. & Esta linha de produtos que está com a Eurochain é o principal é tudo que é vendido no \\
\hline oper & $\begin{array}{l}\text { Há quanto tempo vocês possuem esta parceria? Como é o histórico comercial e } \\
\text { cional? Vocês apresentam boa performance? }\end{array}$ \\
\hline grand & $\begin{array}{l}\text { Operacionalmente falando, posso dizer sobre os fornecedores, em } 2013 \text { tivemos } \\
\text { s dificuldades e problemas na operação, mas sempre tivemos um bom histórico. }\end{array}$ \\
\hline & Está conta é lucrativa? \\
\hline & lucrativa. \\
\hline & 1 - CENTRALIZAÇÃO \\
\hline & SOBRE O FORNECEDOR \\
\hline & Qual o seu contato com os for \\
\hline & Toda a ge \\
\hline é cor & $\begin{array}{l}\text { Quando existem alterações de procedimentos e padrões da operação, o fornecedor } \\
\text { ultado? Vocês são consultados? (existe colaboração?) }\end{array}$ \\
\hline & Confiamos na solução que o operador logístico irá proporcionar. \\
\hline perfo & $\begin{array}{l}\text { Como é feita a seleção de fornecedores? Quais são os critérios? (Preço, } \\
\text { mance, histórico) Qual tem maior influência? }\end{array}$ \\
\hline $\begin{array}{l}\text { neste } \\
\text { negoci } \\
\text { no voll }\end{array}$ & $\begin{array}{l}\text { Abrimos um BID, uma concorrência, colocamos as especificações técnicas, eu ajudo } \\
\text { processo, convidamos alguns fornecedores. Mas eu mesmo não participo das } \\
\text { ações de preço, inclusive devido a regras de compliance, que a operação que influencia } \\
\text { ume e (indiretamente) no pagamento não deve também negociar preços. }\end{array}$ \\
\hline próx & $\begin{array}{l}\text { Como é feito o acompanhamento da performance dos fornecedores? (o controle é } \\
\text { no? Relatórios e reuniões ?) }\end{array}$ \\
\hline & Temos relatórios semanais e diários. Reuniões operacionais mensais e trimestrais. \\
\hline ou ct & $\begin{array}{l}\text { Em média, há quanto tempo vocês trabalham com cada fornecedor? (foco longo } \\
\text { to prazo?) }\end{array}$ \\
\hline vam & $\begin{array}{l}\text { Nossos contratos seguem um padrão, que sempre terão duração de } 3 \text { anos, e depois } \\
\text { renovando a cada } 3 \text { anos. }\end{array}$ \\
\hline & Qual o principal motivo de troca de fornecedores? \\
\hline Logí & $\begin{array}{l}\text { Neste caso não posso responder, pois a Eurochain foi nosso primeiro e único Operador } \\
\text { ico, nunca trocamos. }\end{array}$ \\
\hline refor & $\begin{array}{l}\text { Vocês praticam multas e bônus por performance da operação? (maior controle, } \\
\text { o positivo e negativo) }\end{array}$ \\
\hline $\begin{array}{l}1 \% \text { do } \\
1 \text { mês } \\
\text { melhor }\end{array}$ & $\begin{array}{l}\text { Existe sim, fazemos o cálculo trimestral da performance, temos algo que impacta em } \\
\text { valor do pagamento. A cada } 2 \text { meses com performance acima da média é compensado } \\
\text { abaixo, com isso nossa intenção é o foco na performance operacional e não em } \\
\text { rar nossos custos de logística. }\end{array}$ \\
\hline & stão descontentes, satisfeitos or \\
\hline
\end{tabular}




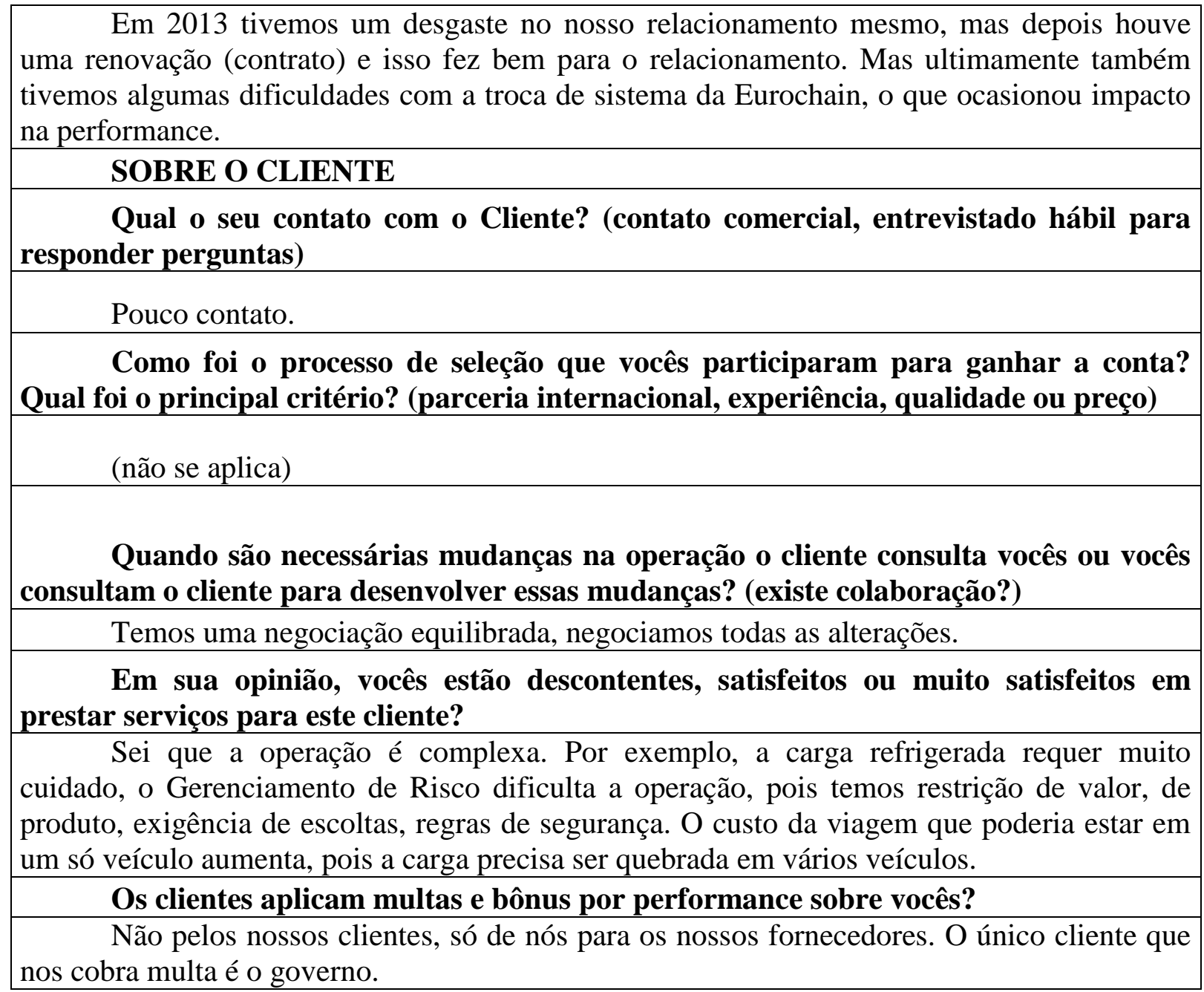




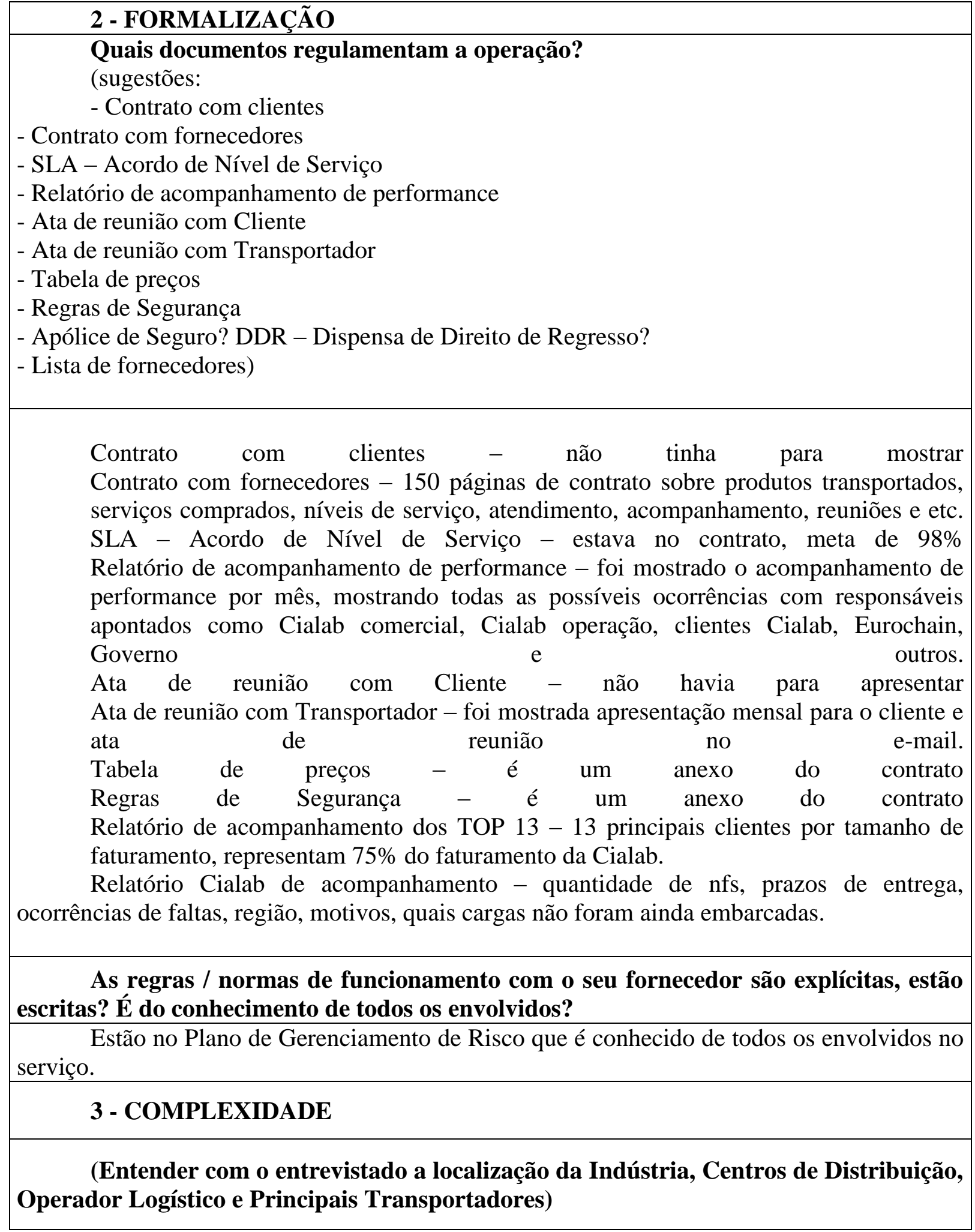


Fábricas próprias no Brasil - Fabricam para todo o mundo.

Fabrica de terceiro no Brasil Brasil.

Volume do que é vendido no Brasil: $60 \%$ vêm de importação e $40 \%$ é produzido no

Todo o recebimento é feito na Eurochain, no Centro de Distribuição deles. Nos também temos um centro de distribuição na planta industrial, mas praticamente não utilizamos.

(Escolher uma localização com volume médio e de importância para se fazer o mapeamento até os últimos níveis de fornecedores)

(Não se aplica)

\section{4 - INTEGRAÇÃO}

Existe algum esforço entre as empresas da cadeia para a criação de colaboração? (Colaboração é a criação de objetivos em comum e confiança)(COUGHLAN et. al. 2003)

Sindusfarma (Sindicato das indústrias farmacêuticas) queria que todas as indústrias se responsabilizassem por meio de lei sobre a coleta e destruição de medicamentos vencidos na casa dos clientes, tivemos grande trabalho para provar que não era viável. Fora isso, não temos outros esforços colaborativos.

\section{OUTRAS INFORMAÇÕES}

- Para a eurochain temos mais de 1000 posições pallets no armazém. Para o nosso outro operador logístico temos 300 posições pallets, ou seja, nossa grande operação é com a Eurochain.

- Só mantivemos 2 operadores porque sabemos que quando o volume dos produtos comuns aumenta muito a tendência é que a atenção dada amostras grátis diminua, assim para termos atenção maior a essa carga demos esta gestão para um operador diferente.

- Alguns pontos de venda colocam tantas complicações operacionais que o custo logístico não compensa a negociação comercial, assim optamos por não ficar neste ponto de venda.

- Há alguns anos atrás, Adquirimos uma grande indústria farmacêutica e nosso volume aumentou muito. Isso não criou uma facilidade, mas nos deixou mais caros, pois devido a algumas restrições da ANVISA ainda precisamos manter ainda dois registros de empresas abertos diferentes, ou seja, precisamos manter essas duas empresas, embora sejamos uma, assim preciso ter duas áreas distintas e separadas no armazém e outras dificuldades operacionais. Mesmo quando temos uma entrega para um cliente que compre produto dessas duas empresas precisamos emitir duas notas fiscais e 2 ctrcs, mesmo as cargas saindo juntas de um mesmo ponto e sendo entregues no mesmo local.

- Nós temos também uma parte de saúde animal, mas que virou outra empresa e não 
está sobre nossa gestão.

- A entrega de matéria prima para as fábricas e a exportação das fábricas não é feito pela Eurochain.

- Quando temos alguma entrega que necessita voltar por algum problema, ela só pode voltar se a área Comercial da Cialab der autorização.

- A força da área comercial da Cialab internamente é muito forte, se temos um pequeno problema na operação, às vezes um problema comum, a alta gestão do continente americano pode ser acionada pela área comercial. Assim, precisamos ter as justificações corretas e claras para gerar o entendimento necessário de todos os envolvidos.

- A área comercial não tem visibilidade de todas as etapas do ciclo do pedido.

- A nossa área comercial é dividida em "Consumer" que são produtos que não precisam de receita e produtos "Farma" que precisam de receita para serem comprados esses representam $90 \%$ do total. Para atender ao governo Brasileiro também existe uma divisão específica do time comercial.

- A logística para o governo é complexa, fazemos entregas para as Secretarias de Saúde e Ministérios, os procedimentos de entrega que eles pedem são complicados, um tipo de palletização trabalhosa, prazos apertados com multas estipuladas na licitação, os produtos também são caros em alguns casos temos mais de $\mathrm{R} \$ 1,5$ milhão por pallet.

- Quebra de gôndola é um problema muito sério para os nossos produtos que competem com genérico, pois caso falte o produto na farmácia ele irá comprar outro, assim perdemos espaço no mercado. Porém em produtos que a patente ainda está vigente temos maior poder de negociação. O mercado onde temos maior concorrência são nos produtos sem receita, com complexo vitamínico, os genéricos e os sem patente. Considerando esse cenário, a logística de distribuição se torna estratégica para a empresa para ganhar e manter a participação no mercado.

- Nós não entregamos para drogarias pequenas, essas são atendidas direto por grandes distribuidores.

- Os distribuidores (clientes da Cialab) são muito fortes comercialmente, às vezes algum problema operacional nosso, para eles não é de todo ruim, pois pode servir como "moeda" de negociação, assim se temos algum problema na entrega isso pode gerar um pedido de prorrogação de pagamento por parte dos distribuidores. O distribuidor impõe condições para receber a carga que aumentam os nossos custos para que eles possam ter menos trabalho na conferência e recebimento, mas o custo fica conosco.

- Minha maior expectativa com relação ao operador logístico é o indicador OTIF (on time in full), ou seja, entrega completa, sem avarias, faltas ou sobras no prazo.

- Uma grande rede de drogarias de São Paulo, por exemplo, apesar de ser grande, para nós é considerado um cliente médio, esse tipo de cliente não possuiu tanto poder de influência, quanto os grandes, os chamados Top 13. Destes Top 13, 9 são distribuidores de medicamentos e 4 são grandes redes de farmácia, os Top 13 representam $75 \%$ do faturamento da Cialab. Temos um relatório de acompanhamento específico para eles. Cada um dos grandes clientes possui gerentes específicos para acompanhar esses clientes especiais.

- Antigamente alguns destes distribuidores eram empresas familiares, pouco 
profissionalizadas, atualmente eles se profissionalizaram e estão mais exigentes. Alguns foram comprados por multinacionais.

- Em alguns casos eles não devolvem o canhoto na hora, pois devido a questões fiscais recebem a mercadoria em um local, mas irão armazená-la em outro, assim só recebem a carga, mas irão conferir só no destino final, enquanto não conferem, não devolvem o canhoto.

- Uma oportunidade de melhoria na operação seria se pudéssemos consolidar notas dos clientes, ao invés do cliente fazer 200 pedidos picados, fizéssemos uma única entrega consolidada.

- Nossos maiores dificuldades são com relação à falta de retorno rápido das informações de entrega da Eurochain 
Questionário sobre autonomia para execução do serviço

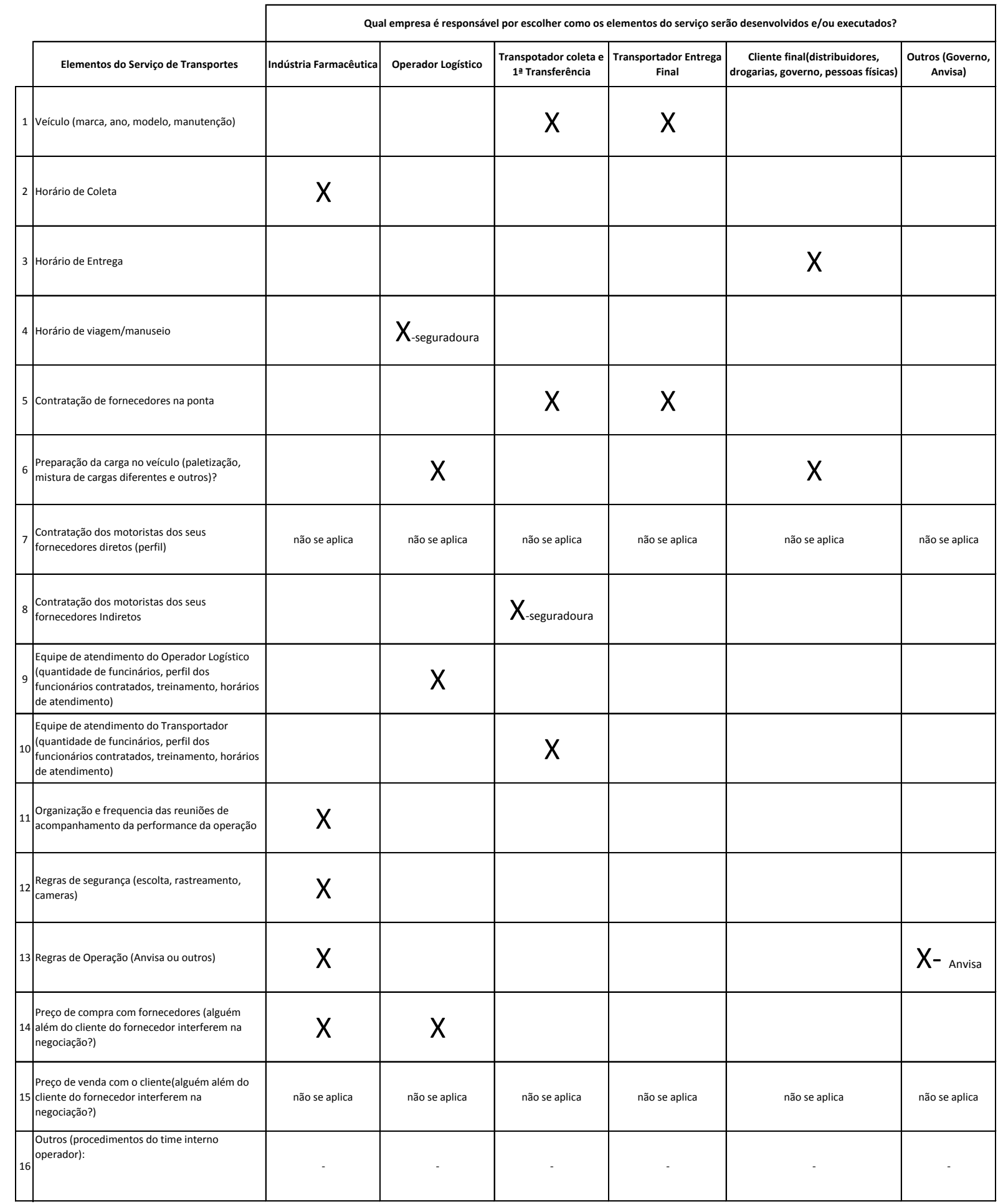

\begin{tabular}{|c|c|c|c|c|c|c|}
\hline Cialab & Indústria Farmacêutica & Operador Logístico & $\begin{array}{c}\text { Transpotador coleta e } \\
\text { 1@ Transferência }\end{array}$ & $\begin{array}{c}\text { Transportador Entrega } \\
\text { Final }\end{array}$ & $\begin{array}{c}\text { Cliente final(distribuidores, } \\
\text { drogarias, governo, pessoas físicas) }\end{array}$ & $\begin{array}{c}\text { Outros (Governo, } \\
\text { Anvisa) }\end{array}$ \\
\hline Quantidade de Elementos & 4 & 4 & 5 & 2 & 2 & 1 \\
\hline Quais elementos & \begin{tabular}{|l|} 
Regras de Segurança, \\
Operação, horários de \\
coleta e reuniões de \\
acompanhamento
\end{tabular} & $\begin{array}{l}\text { Modo de preparo da } \\
\text { carga, horários de } \\
\text { viagem, e equipe de } \\
\text { atendimento }\end{array}$ & $\begin{array}{l}\text { Veículo, fornecedores, } \\
\text { motoristas e equipe de } \\
\text { atendimento }\end{array}$ & Veículo, fornecedores & $\begin{array}{l}\text { Horário de entrega e modo de } \\
\text { preparo da carga }\end{array}$ & $\begin{array}{l}\text { Regras de } \\
\text { operação }\end{array}$ \\
\hline
\end{tabular}

Comentário:

De acordo com a visão da Cialab existe o controle rígido das questões de segurança da carga, já que este é um risco a ser controlado,porém com exceção dos temas que possuem interface direta com a Cialab, como reuniões, os outros temas operacionais não possuem interferência direta, sendo que os fornecedores tem autonomia para trabalhar dentro das regras legais para cargas de medicamento. 
8.5 Anexos V - Entrevistas 4 Sul Deste Cargo

Questionário - Sul Deste Cargo

\begin{tabular}{|l|}
\hline CARACTERIZAÇÃO (EMPRESA E ENTREVISTADO) \\
\hline Qual o seu cargo e função? \\
\hline Gerente de São Paulo \\
\hline Há quantos anos você está na empresa? Há quantos anos nesta função? \\
\hline Há mais de 1 ano. \\
\hline Qual o número de funcionários? \\
\hline 1300 em toda a empresa \\
\hline Qual o faturamento anual? \\
\hline R $\$ 250$ milhões em toda empresa / $\mathrm{R} \$ 180$ milhões só no rodoviário / $30 \%$ do \\
\hline
\end{tabular}
rodoviário é do setor farmacêutico / 60\% desses $30 \%$ é da conta Eurochain

Qual o total em compras de seviços logísticos?

Não sei dizer de cabeça.

Quais serviços a sua empresa vende?

Transportes aéreo, rodoviário e gerenciamento do transporte

Quantos clientes e quantos fornecedores vocês possuem?

Em torno de 500 clientes ativos, mas alguns são bem pequenos com pouquíssimas entregas por mês, todos pessoas jurídicas. Temos 21 fornecedores

Quais áreas de sua organização são responsáveis pelo contato com o cliente e com os fornecedores?

Cada unidade de cada estado é responsável por falar com o cliente. Possuímos 14 filiais próprias. No nosso caso eu cuido de São Paulo.

Por favor, me dê uma ideia geral da operação: pedido (faturamento), coleta, entrega. Frequências de coleta. Modais utilizados. $\mathbf{E}$ acompanhamento.

Recebemos os próximos embarques pelos sistemas e fazemos a nossa programação de coleta e entregas.

Perguntas sobre fornecedores

Quantos são os fornecedores que atuam para este laboratório?

21 fornecedores que nos contratamos

Quais são os fornecedores mais importantes ou de maior expressão? Por quê?

Todos são importantes

Há quanto tempo vocês trabalham com estes fornecedores? Como é o histórico comercial e operacional? Eles apresentam boa performance?

Em São Paulo só temos um fornecedor, e não temos muito histórico, estamos com ele há 6 meses e tem sido bom o nível de serviço, anteriormente tínhamos esse serviço feito pela própria Sul Deste Cargo, não dependíamos de outras empresas, mas agora o volume aumentou.

\begin{tabular}{|l|}
\hline Perguntas sobre o cliente \\
\hline Qual o seu faturamento com o cliente em questão? \\
\hline Não sei de cabeça. \\
\hline Confirme o tipo de serviço que vocês prestam para este cliente? \\
\hline Transporte rodoviário. \\
\hline
\end{tabular}




\begin{tabular}{|c|}
\hline Qual a importância desta conta para vocês? Por quê? \\
\hline É uma conta muito importante \\
\hline $\begin{array}{l}\text { Há quanto tempo vocês possuem esta parceria? Como é o histórico comercial e } \\
\text { operacional? Vocês apresentam boa performance? }\end{array}$ \\
\hline $\begin{array}{l}\text { Há mais de } 10 \text { anos. Tivemos momentos bons e ruins. A Eurochain aperta muito nos } \\
\text { preços, ela é bem agressiva também nos níveis de serviço e na cobrança, mas também a área é } \\
\text { exigente devido à vigilância sanitária. }\end{array}$ \\
\hline Está conta é lucrativa? \\
\hline $\begin{array}{l}\text { Sim, a conta é lucrativa, mas precisa ter controle da operação, caso tenha erros } \\
\text { operacionais é fácil transformar a conta em prejuízo, se eu perco um horário de coleta, ou } \\
\text { transferência. Se errarmos no faturamento a Eurchain pede prorrogação de mais } 30 \text { dias para } \\
\text { pagarmos. }\end{array}$ \\
\hline 1 - CENTRALIZAÇÃO \\
\hline SOBRE O FORN \\
\hline Qua \\
\hline ele, pois é só um. \\
\hline $\begin{array}{l}\text { e padrões da operação, o fornecedor } \\
\text { acão?) }\end{array}$ \\
\hline $\begin{array}{l}\text { Da gente para nossos fornecedores é mais no estilo “top down”. Da Eurochain para nós } \\
\text { é mais uma negociação conjunta. }\end{array}$ \\
\hline $\begin{array}{l}\text { Como é feita a seleção de fornecedores? Quais são os critérios? (Preço, } \\
\text { performance, histórico) Qual tem maior influência? }\end{array}$ \\
\hline $\begin{array}{l}\text { Neste caso foi indicação de outros concorrentes com quem mantemos bom } \\
\text { relacionamento. }\end{array}$ \\
\hline $\begin{array}{l}\text { Como é feito o acompanhamento da performance dos fornecedores? (o controle é } \\
\text { próximo? Relatórios e reuniões ?) }\end{array}$ \\
\hline Mensal, cada filial é responsável pelos seus fornecedores. \\
\hline $\begin{array}{l}\text { Em média, há quanto tempo vocês trabalham com cada fornecedor? (foco longo } \\
\text { ou curto prazo?) }\end{array}$ \\
\hline ( \\
\hline Qua \\
\hline $\begin{array}{l}\text { Não cabe, não há troca. Com relação aos motoristas agregados temos um turnover de } \\
8 \% \text { dos motoristas por ano. }\end{array}$ \\
\hline $\begin{array}{l}\text { Vocês praticam multas e bônus por performance da operação? (maior controle, } \\
\text { reforço positivo e negativo) }\end{array}$ \\
\hline $\begin{array}{l}\text { Existe sim multa da Eurochain para nós, é recente, mas a cada problema na entrega } \\
\text { podemos perder até } 20 \% \text { do valor de frete. De nós para o nosso transportador não há multas e } \\
\text { bônus. }\end{array}$ \\
\hline $\begin{array}{l}\text { Em sua opinião, os seus fornecedores em média estão descontentes, satisfeitos ou } \\
\text { muito satisfeitos em prestar serviços para vocês? }\end{array}$ \\
\hline s há mais de 10 anos trabalhando \\
\hline SOB \\
\hline $\begin{array}{l}\text { contato com o Cliente? (contato comercial, entrevistado hábil } \\
\text { tas) }\end{array}$ \\
\hline
\end{tabular}


e comercial.

A Sul Deste Cargo não pode falar com a Cialab por clausula contratual, porém pode falar com os distribuidores para fazer o agendamento da carga.

Como foi o processo de seleção que vocês participaram para ganhar a conta? Qual foi o principal critério? (parceria internacional, experiência, qualidade ou preço)

Não sei dizer foi há mais de 10 anos.

Quando são necessárias mudanças na operação o cliente consulta vocês ou vocês consultam o cliente para desenvolver essas mudanças? (existe colaboração?)

Existe uma negociação em comum, não é "top down", mas eles tem um controle forte. A nossa posição com os nossos fornecedores já é mais pesado, um pouco "top down"

Em sua opinião, vocês estão descontentes, satisfeitos ou muito satisfeitos em prestar serviços para este cliente?

Contentes. A Eurochain ela sofre junto, está junto na operação. Nós somos diferenciados do mercado, temos processos e controle, por isso também somos cobrados de forma diferenciada, com mais rigor. Não temos muitos concorrentes que conseguem atender uma exigência tão grande de controles.

Os clientes aplicam multas e bônus por performance sobre vocês?

Para os nossos contratados não existem multas e bônus, só da Eurochain para nós, mas nós nunca ganhamos bônus.

\section{2 - FORMALIZAÇÃO}

Quais documentos regulamentam a operação?

(sugestões:

- Contrato com clientes

- Contrato com fornecedores

- SLA - Acordo de Nível de Serviço

- Relatório de acompanhamento de performance

- Ata de reunião com Cliente

- Ata de reunião com Transportador

- Tabela de preços

- Regras de Segurança

- Apólice de Seguro? DDR - Dispensa de Direito de Regresso?

- Lista de fornecedores)

- Regras do Plano de Gerenciamento de Risco são cadastradas no sistema - acusa automaticamente quando sai uma carga acima do valor permitido -( visualizado um caso no dia da visita.)

-- Reunião com fornecedor dele é mais informal, não existe ata ou relatório.

- Relatório da demanda do dia com todas as notas fiscais que serão carregadas de todos os laboratórios.

- Contrato de agregado da Sul Deste Cargo; tipo de veículo, responsabilidades e direitos, regras e pagamento e seguro, treinamentos necessários e avaliação do veículo. 9 páginas.

- Regulamentação da ANTT

- Regras da Gerenciadora de Risco

- Manual de Procedimentos e Processos 


- Instrução de operação do Rastreador do veículo
- Avaliação do treinamento dado aos agregados e parceiros
- Tabelas de preços com custos por região e peso, além de indicadores pelos quais
serão cobrados.(Eurochain - Sul Deste Cargo)
- Controle interno de nível de serviço no Excel; relatório de performance por filial e
por nota fiscal.
- Apresentação da reunião com a Eurochain - 11 slides sobre performance de entrega,
avaria e faltas, canhotos e informações de entrega, apresentados por cliente e por destino,
todos os laboratórios juntos, pendências de ressarcimentos.
- Ata de reunião Eurochain com Sul Deste Cargo - relação de problemas operacionais
- Relatório de Agregados com problemas - nome do agregado e ocorrência
- Manuais sobre manuseio da carga na Sul Deste Cargo em PDF.

As regras / normas de funcionamento com o seu fornecedor são explícitas, estão escritas? É do conhecimento de todos os envolvidos?

Sim, possuímos nossas regras de operação com o nosso fornecedor por escrito.

A Sul Deste Cargo não pode falar com a Cialab por clausula contratual, porém pode falar com os distribuidores para fazer o agendamento da carga.

\section{3 - COMPLEXIDADE}

(Entender com o entrevistado a localização da Indústria, Centros de Distribuição, Operador Logístico e Principais Transportadores)

(O entrevistado forneceu uma lista e um mapa com os 21 fornecedores)

(Escolher uma localização com volume médio e de importância para se fazer o mapeamento até os últimos níveis de fornecedores)

\section{4 - INTEGRAÇÃO}

Existe algum esforço entre as empresas da cadeia para a criação de colaboração? (Colaboração é a criação de objetivos em comum e confiança)(COUGHLAN et. al. 2003)

"Já fizemos parcerias com concorrentes nossos para trazer carga deles em casos onde nossos veículos fariam uma viagem com o veículo vazio e vice-versa.”

"Neste caso foi indicação de outros concorrentes com quem mantemos bom relacionamento."

\section{- OUTRAS INFORMAÇÕES}


- Em são Paulo temos 50 veículos de frota própria e mais 10 agregados.

- No total temos 400 frota própria e 600 agregados.

- Agregado compra combustível mais barato na TA.

- Há mais de 10 anos. Tivemos momentos bons e ruins. A Eurochain aperta muito nos preços, ela é bem agressiva também nos níveis de serviço e na cobrança, mas também a área é exigente devido à vigilância sanitária.

- Contentes. A Eurochain ela sofre junto, está junto na operação. Nós somos diferenciados do mercado, temos processos e controle, por isso também somos cobrados de forma diferenciada, com mais rigor. Não temos muitos concorrentes que conseguem atender uma exigência tão grande de controles

- Gastamos 1,5 milhões por ano para farma para manutenção de licenças e estrutura.

- Problema no sistema da Eurochain, cargas saem com falta, o sistema deles parece não ter acompanhado o crescimento da operação.

- Falta comunicação interna entre a operação e o time de atendimento da Eurochain, ás vezes a operação me pede para segurar uma entrega, mas depois sou cobrado do atraso dessa entrega, mas foram eles mesmos que pediram para eu bloquear a entrega.

- O poder dos distribuidores é muito grande, eles são os grandes clientes dos laboratórios, assim o laboratório nunca quer entrar em conflito com os seus clientes, dessa forma quando temos problemas estoura para o lado da Eurochain e para o lado da Sul Deste Cargo.

- Algumas unidades os parceiros são empresas com outro CNPJ, mas utilizam os sistema e os procedimentos da Sul Deste Cargo.

- Da Eurochain trabalhamos com 19 laboratórios no total.

- Temos uma média de ocupação de $70 \%$ da capacidade dos veículos.

- Tudo que coletamos até às 21:30 viaja no mesmo dia, horários foram definidos em acordo comum.

- As informações e previsões de carga da Eurochain são muito boas.

- 3 a 4 carretas por dia de coleta na Eurochain.

Sobre visitação

- Foi possível observar as docas com as placas dos clientes, ou seja, docas dedicadas para receber os veículos da Eurochain, são docas exclusivas.

- No armazém da Sul Deste Cargo não havia uma área segregada para a carga de medicamentos, pois conforme informado a carga nem era estocada, mas apenas transferida de veículo, o chamado "cross-docking" ou cruzamento de docas, procedimento comum nas transportadoras. Processo no qual chega carga com diversos destinos e elas são consolidadas para formar volume para cada um dos destinos em específico.

- O galpão tinha em torno de 6 mil m2 e havia uma área segregada para cargas com problema que estavam aguardando uma solução.

- O armazém era limpo, sem sujeiras no chão. As cargas estavam organizadas por 
cliente e sempre em movimentação de um veículo para outro. 
Questionário sobre autonomia para execução do serviço

\begin{tabular}{|c|c|c|c|c|c|c|c|}
\hline & & & empresa é responsáv & el por escolher como os & elementos do serviço ser & ão desenvolvidos e/ou executados? & \\
\hline & Elementos do Serviço de Transportes & Indústria Farmacêutica & Operador Logístico & $\begin{array}{c}\text { Transpotador coleta e } \\
\text { 1ª Transferência }\end{array}$ & $\begin{array}{c}\text { Transportador Entrega } \\
\text { Final }\end{array}$ & $\begin{array}{c}\text { Cliente final(distribuidores, } \\
\text { drogarias, governo, pessoas fisicas) }\end{array}$ & $\begin{array}{c}\text { Outros (Governo, } \\
\text { Anvisa) }\end{array}$ \\
\hline 1 & Veículo (marca, ano, modelo, manutenção) & & & & & & \\
\hline 2 & Horário de Coleta & & & & & & \\
\hline 3 & Horário de Entrega & & X & & & X & \\
\hline 4 & Horário de viagem/manuseio & & $X$ - seguradora & $X$ - seguradora & & & \\
\hline 5 & Contratação de fornecedores na ponta & & & & & & \\
\hline 6 & $\begin{array}{l}\text { Preparação da carga no veículo (paletização, } \\
\text { mistura de cargas diferentes e outros)? }\end{array}$ & & X & & & $X$ & \\
\hline 7 & $\begin{array}{l}\text { Contratação dos motoristas dos seus } \\
\text { fornecedores diretos (perfil) }\end{array}$ & & & & & & \\
\hline 8 & $\begin{array}{l}\text { Contratação dos motoristas dos seus } \\
\text { fornecedores Indiretos }\end{array}$ & & & & & & \\
\hline 9 & $\begin{array}{l}\text { Equipe de atendimento do Operador Logístico } \\
\text { (quantidade de funcinários, perfil dos } \\
\text { funcionários contratados, treinamento, horários } \\
\text { de atendimento) }\end{array}$ & & & & & & \\
\hline 10 & $\begin{array}{l}\text { Equipe de atendimento do Transportador } \\
\text { (quantidade de funcinários, perfil dos } \\
\text { funcionários contratados, treinamento, horários } \\
\text { de atendimento) }\end{array}$ & & & & X & & \\
\hline 11 & $\begin{array}{l}\text { Organização e frequencia das reuniões de } \\
\text { acompanhamento da performance da operação }\end{array}$ & & X & X & & & \\
\hline 12 & $\begin{array}{l}\text { Regras de segurança (escolta, rastreamento, } \\
\text { cameras) }\end{array}$ & & & $X$ - seguradora & & & \\
\hline 13 & Regras de Operação (Anvisa ou outros) & & & & & & $X$ \\
\hline 14 & $\begin{array}{l}\text { Preço de compra com fornecedores (alguém } \\
\text { além do cliente do fornecedor interferem na } \\
\text { negociação?) }\end{array}$ & & X & $X$ & & & \\
\hline 15 & $\begin{array}{l}\text { Preço de venda com o cliente(alguém além do } \\
\text { cliente do fornecedor interferem na } \\
\text { negociação?) }\end{array}$ & & & $\mathbf{X}$ & X & & \\
\hline 16 & $\begin{array}{l}\text { Outros (procedimentos do time interno } \\
\text { operador): }\end{array}$ & & & & & & \\
\hline
\end{tabular}

\begin{tabular}{|c|c|c|c|c|c|c|}
\hline Sul Deste Cargo & Indústria Farmacêutica & Operador Logístico & \begin{tabular}{|c|} 
Transpotador coleta e \\
1a Transferência
\end{tabular} & $\begin{array}{c}\text { Transportador Entrega } \\
\text { Final }\end{array}$ & $\begin{array}{c}\text { Cliente final(distribuidores, } \\
\text { drogarias, governo, pessoas físicas) }\end{array}$ & $\begin{array}{c}\text { Outros (Governo, } \\
\text { Anvisa) }\end{array}$ \\
\hline Quantidade de Elementos & 0 & 5 & 8 & 2 & 2 & 1 \\
\hline Quais elementos & - & $\begin{array}{l}\text { Horários, preparação } \\
\text { da carga e reuniões de } \\
\text { acompanhamento }\end{array}$ & $\begin{array}{l}\text { Veículo, horários, } \\
\text { contrato de } \\
\text { fornecedores, equipe } \\
\text { de atendimento, } \\
\text { reuniões, }\end{array}$ & $\begin{array}{l}\text { Motoristas e equipe de } \\
\text { atendimento. }\end{array}$ & $\begin{array}{l}\text { Horário de recebimento e } \\
\text { preparação da carga. }\end{array}$ & $\begin{array}{l}\text { regras de operação } \\
\text { Anvisa }\end{array}$ \\
\hline
\end{tabular}


8.6 Anexos VI - Entrevistas 5 Air Cargo

Questionário - Air Cargo

\begin{tabular}{|l|}
\hline CARACTERIZAÇÃO (EMPRESA E ENTREVISTADO) \\
\hline Qual o seu cargo e função? \\
\hline Gerente Comercial e Operacioanal \\
\hline Há quantos anos você está na empresa? Há quantos anos nesta função? \\
\hline Há mais de 1 ano. \\
\hline Qual o número de funcionários? \\
\hline 500 funcionários em todo o Brasil. \\
\hline Qual o faturamento anual? \\
\hline $\begin{array}{l}\text { De toda a empresa é de mais de R } \$ 200 \text { mi, do farmacêutico foi R\$ } 48 \text { milhões. } \\
\text { A conta toda da Eurochain equivale a em torno de } 40 \% \text { do total do faturamento da } \\
\text { empresa. As contas do farmacêutico da Eurochain equivalem a } 90 \% \text { do nosso faturamento do } \\
\text { setor farmacêutico. }\end{array}$ \\
\hline
\end{tabular}

Qual o total em compras de seviços logísticos?

R\$ 36 milhões por ano no aéreo, R\$30 milhões estão concentrados em uma única companhia aérea. Fora isso, temos altos gastos de terceiros, motoristas agregados, infraestrutura e folha de pagamento.

Quais serviços a sua empresa vende?

Vendemos transporte rodoviário e aéreo e todo o acompanhamento da entrega em um único serviço. No caso Eurochain, eles apenas compram nosso serviço aéreo.

Quantos clientes e quantos fornecedores vocês possuem?

Trabalhamos com 4 companhias aéreas e mais 35 empresas parceiras que trabalham na distribuição das cargas em nossas 35 bases.

Quais áreas de sua organização são responsáveis pelo contato com o cliente e com os fornecedores?

Com o cliente temos uma área de atendimento por telefone para passar informações, temos a área comercial para conversar com o compras da Eurochain. Com o fornecedor também temos uma equipe para fazer acompanhamento. Operacionalmente e comercialmente eu entro em contato com os fornecedores. Na Eurochain temos 14 colaboradores internos para trabalhar com a carga antes do carregamento.

Por favor, me dê uma ideia geral da operação: pedido (faturamento), coleta, entrega. Frequências de coleta. Modais utilizados. E acompanhamento.

Eles recebem uma programação das cargas por e-mail e programam a coleta de lá partem diretamente para o aeroporto, na maioria dos casos. Casos onde seja uma carga muito complexa para se conferir eles fazem a conferência dentro da Air Cargo, pois na Eurochain e no aeroporto não existe muito espaço disponível. Em seguida os seus parceiros são avisados e fazem as coletas e as entregas conforme agendamentos passados.

Perguntas sobre fornecedores

Quantos são os fornecedores que atuam para este laboratório?

Para o cliente Cialab trabalhamos com 4 companhias aéreas e mais 35 empresas parceiras que trabalham na distribuição das cargas em nossas 35 bases, porém deve se retirar um que é de São Paulo, pois no Estado de São Paulo não fazemos aéreo para a Cialab.

Quais são os fornecedores mais importantes ou de maior expressão? Por quê?

Todos os parceiros são importantes, alguns tem maior peso devido ao volume que carregam. 
Há quanto tempo vocês trabalham com estes fornecedores? Como é o histórico comercial e operacional? Eles apresentam boa performance?

Temos transportadores que trabalham conosco há mais de 10 anos, mas em média considero 5 anos. Sim, eles apresentam uma boa performance.

\section{Perguntas sobre o cliente}

Qual o seu faturamento com o cliente em questão?

Com a Eurochain é de R\$ 80 milhões por ano, só de farmacêutico temos R \$ 43 milhões por ano. Não sei dizer quanto desses $\mathrm{R} \$ 43$ milhões é representado pela Cialab

\section{Confirme o tipo de serviço que vocês prestam para este cliente?}

Transporte aéreo para todo o Brasil, inclusive serviços de emergência como próximo vôo, que são mais caros que o transporte aéreo convencional. Neste transportes está incluso a última entrega que é um trecho rodoviário até o destinatário final, esta etapa também é de responsabilidade nossa, Air Cargo.

\section{Qual a importância desta conta para vocês? Por quê?}

O faturamento deles é muito representativo para nós. Nós dentro da empresa temos a função de manter esta conta, nossa primeira missão aqui é esta. Investimos muito, entramos no mercado a partir de 2011 com todas as licenças necessárias, por isso existe grande expectativa sobre esta conta, principalmente no farmacêutico.

Há quanto tempo vocês possuem esta parceria? Como é o histórico comercial e operacional? Vocês apresentam boa performance?

Já faz 2,5 anos que temos esta conta Eurochain e Cialab. Houve muita dificuldade no início, pois logo no começo houve um aumento muito grande de volume, 2012, depois da Cialab adquirir uma outra empresa que veio ser atendida pela Eurochain e Air Cargo também. Em 2013 a Eurochain fez uma alteração operacional que nos ajudou muito e assim melhoramos bastante a operação. Esta mudança foi uma alteração separação da carga, o sistema era muito automatizado, mas ocorriam muitos erros, depois a Eurochain começou a incluir mais pessoas para fazer a conferência só então novamente melhorou a performance.

\section{Está conta é lucrativa?}

Sim, é uma conta lucrativa.

1 - CENTRALIZAÇÃO

SOBRE O FORNECEDOR

Qual o seu contato com os fornecedores?

Comercial, meu time acompanha as entregas com o time dos fornecedores e quando preciso faço reuniões com eles.

Quando existem alterações de procedimentos e padrões da operação, o fornecedor é consultado? Vocês são consultados? (existe colaboração?)

Na relação Eurochain conosco é tudo feito a 4 mãos, não é “topdown”.

Entre nós e os nossos fornecedores tentamos negociar tudo, porém já cortamos fornecedores que não quiseram se adequar aos nossos requisitos, fornecedores que não quiseram investir em sua estrutura.

Como é feita a seleção de fornecedores? Quais são os critérios? (Preço, performance, histórico) Qual tem maior influência?

Primeiro verificamos se ele possui todos os requisitos do manual de fornecedores, depois vemos o preço. Também conversamos com o mercado, vemos quem são os fornecedores de confiança.

Como é feito o acompanhamento da performance dos fornecedores? (o controle é próximo? Relatórios e reuniões ?) 

Não acompanhamos a performance por fornecedor, somente a performance total.
Quando temos problemas fazemos reuniões. Temos um projeto que já está iniciado para
fazermos o acompanhamento por fornecedores.
Com a Eurochain somos cobrados com base em diversos indicadores como: entregas
no prazo, entregas completas sem faltas ou avarias, informações corretas, coletas no prazo,
retorno de canhotos.

Em média, há quanto tempo vocês trabalham com cada fornecedor? (foco longo ou curto prazo?)

Em média há 5 anos, alguns já estão conosco há mais de 10 anos.

Qual o principal motivo de troca de fornecedores?

Não cumprimento do procedimento ou não adequação as necessidades. Tínhamos um fornecedor que possuía diversas entregas para fazer junto com as nossas em um carro só, porém quando precisávamos que ele esperasse mais em uma entrega ele saia do local sem a minha autorização.

Vocês praticam multas e bônus por performance da operação? (maior controle, reforço positivo e negativo)

Ainda não é aplicado, mas será em 2015. (da Eurochain sobre a Air Cargo)

Em sua opinião, os seus fornecedores em média estão descontentes, satisfeitos ou muito satisfeitos em prestar serviços para vocês?

Temos parcerias há muitos anos, trocar o fornecedor é em último caso. Sempre tentamos desenvolvê-los.

SOBRE O CLIENTE

Qual o seu contato com o Cliente? (contato comercial, entrevistado hábil para responder perguntas)

Nenhum. Por contrato não podemos falar com o cliente do cliente, ou seja, não falamos com a Cialab.

Como foi o processo de seleção que vocês participaram para ganhar a conta? Qual foi o principal critério? (parceria internacional, experiência, qualidade ou preço)

Nesta questão pesou mais o histórico comercial. (O entrevistado não quis aprofundar mais este assunto)

Quando são necessárias mudanças na operação o cliente consulta vocês ou vocês consultam o cliente para desenvolver essas mudanças? (existe colaboração?)

Sim, tudo é feito a 4 mãos. Porém, creio que isso também tem relação com a nossa importância para eles, pois já trabalhei com a Eurochain por outras empresas, porém não era ouvido nas propostas de melhorias que fiz, porém hoje sou ouvido nas mesmas propostas.

Em sua opinião, vocês estão descontentes, satisfeitos ou muito satisfeitos em prestar serviços para este cliente?

Operacionalmente vamos muito bem, melhorou muito, porém financeiramente não, a Eurochain nos aperta demais no preço, não sei de onde eles tiram preços base tão baixos para negociar.

Os clientes aplicam multas e bônus por performance sobre vocês?

Não existe multas e bônus por enquanto, só o projeto.

2 - FORMALIZAÇÃO 


\begin{tabular}{|c|}
\hline $\begin{array}{l}\quad \text { Quais documentos regulamentam a operação? } \\
\quad \text { (sugestões: } \\
\text { - Contrato com clientes } \\
\text { - Contrato com fornecedores } \\
\text { - SLA - Acordo de Nível de Serviço } \\
\text { - Relatório de acompanhamento de performance } \\
\text { - Ata de reunião com Cliente } \\
\text { - Ata de reunião com Transportador } \\
\text { - Tabela de preços } \\
\text { - Regras de Segurança } \\
\text { - Apólice de Seguro? DDR - Dispensa de Direito de Regresso? } \\
\text { - Lista de fornecedores) }\end{array}$ \\
\hline $\begin{array}{l}\text { Materiais entregues ao pesquisador para análise; } \\
\text { - apresentação comercial } \\
\text { - SAC - solicitação de ação corretiva para o fornecedor - consta descrição do } \\
\text { problema, gráfico espinha de peixe, ishikawa, ação corretiva, responsável e prazo. } \\
\text { - Ata de reunião entre Air Cargo e Eurochain com lista de problemas e ações corretivas } \\
\text { e prazos para solução. } \\
\text { - Contrato com Fornecedor - trata de temas como segurança de informação, cuidado } \\
\text { sobre os funcionários, ressarcimento por descumprimento de prazo de perecíveis e outros. } 25 \\
\text { páginas. } \\
\text { - Tabela de preço de fornecedor - tipos de veículos utilizados e seus respectivos } \\
\text { custos. } \\
\text { - Controle de Licenças de fornecedores - por exemplo, vistoria dos bombeiros, data de } \\
\text { emissão e data de validade. } 18 \text { licenças avaliadas. } \\
\text { - Ficha cadastral do fornecedor - tipos de produtos que irá carregar, licenças, } \\
\text { endereços e outros dados. } \\
\text { - Relatório de Performance Air Cargo e todas as contas da Eurochanel. Indicadores de } \\
\text { entrega e informação no prazo por cliente, por estado, target de nível de serviço, por semana. } \\
\text { - Lista de Documentos pedidos para os motoristas agregados - diversos documentos } \\
\text { como registro no RNTRC, perfil do motorista avaliado pela seguradora. } \\
\text { - Manual para contratação - trata sobre os documentos e certificações que um } \\
\text { fornecedor deve possuir, além disso deve conhecer sobre os produtos carregados e os } \\
\text { procedimentos da transportadora, inclusive sobre o tratamento de futuros problemas. } \\
\text { - Regras de Gerenciamento de Risco - regras de } 18 \text { laboratórios em um único } \\
\text { documento 1. } \\
\text { - Programação dos vôos disponíveis fornecido pela companhia aérea para o } \\
\text { planejamento da Air Cargo. }\end{array}$ \\
\hline
\end{tabular}

As regras / normas de funcionamento com o seu fornecedor são explícitas, estão escritas? É do conhecimento de todos os envolvidos?

Cobramos dos fornecedores todas as licenças, por exemplo, bombeiros, análise do CNPJ, vigilância sanitária. Além disso, o fornecedor recebe o nosso manual de procedimentos do fornecedor.

\section{3 - COMPLEXIDADE}

(Entender com o entrevistado a localização da Indústria, Centros de Distribuição, Operador Logístico e Principais Transportadores)

Possuem uma filial em cada capital e mais 9 bases de apoio. 
(Escolher uma localização com volume médio e de importância para se fazer o mapeamento até os últimos níveis de fornecedores)

(não se aplica)

\section{4 - INTEGRAÇÃO}

Existe algum esforço entre as empresas da cadeia para a criação de colaboração? (Colaboração é a criação de objetivos em comum e confiança)(COUGHLAN et. al. 2003) mundo.

Não existe, não temos nenhum tipo de "cadeia colaborativa", cada um olha o seu

Também conversamos com o mercado, vemos quem são os fornecedores de confiança. (sobre auxílio para contratação de fornecedores)

\section{OUTRAS INFORMAÇÕES}

- $85 \%$ das nossas entregas são finalizadas por nós ou nossos parceiros mesmos na base da entrega, sem necessidade de um terceiro fornecedor envolvido.

- Investimos muito, entramos no mercado a partir de 2011 com todas as licenças necessárias, por isso existe grande expectativa sobre esta conta, principalmente no farmacêutico. (comentaram que para retirar as licenças costuma demorar em torno de 6 meses há 1 ano)

- Os requisitos para entrar no setor de farmacêuticos são altos, sabemos de poucas empresas que competem conosco, consigo citar somente 5.

- Investimos mais de 400 mil em reformas para nos adaptarmos para estas operações.

- O mercado farmacêutico exige muito, mas ainda remunera bem.

Sobre parcerias e bom relacionamento com fornecedores:

- Temos um bom relacionamento com as companhias aéreas, assim temos informações também, ficamos sabendo que a Eurochain iria falar direto com a Companhias Aéreas, a companhia aérea devido a nossa parceria não apresentou propostas agressivas para não nos tirar a conta.

- Pratica de mercado. Não é comum uma empresa apresentar os dois serviços de transporte aéreo e rodoviário, o normal é haver uma empresa só para ser especialista em um dos serviços.

- As áreas operacionais e comerciais de todas as empresas brigam aqui tentamos ter muito diálogo.

- Histórico: Até 2010 não tínhamos o setor farmacêutico, tínhamos somente o aéreo para o setor eletrônico.

- Mercado: Os requisitos para entrar no setor de farmacêuticos são altos, sabemos de poucas empresas que competem conosco, consigo citar somente 5.

Temos diversas diferentes licenças da Anvisa como:

- Insumos 
- Correlatos

- Medicamentos

- Controlados

- Cosméticos

- Saneantes

- Relacionamento: A Eurochain nos aperta financeiramente, mas confia no nosso serviço.

- (no dia da entrevista eles tiveram uma auditoria surpresa de um dos clientes farmacêuticos)

- Quando nos chegamos, das 15 pessoas do time atual, 2 pessoas ficaram na equipe para passar informações para concorrentes.

- O mercado de aéreo no farmacêutico atualmente não apresenta contas (clientes) que gerem mais de $\mathrm{R} \$ 1$ milhão de faturamento por mês.

- Investimos mais de 400 mil em reformas para nos adaptarmos para estas operações.

- As companhias aéreas que transportam cargas são as mesmas companhias que transportam pessoas. Em nossa principal companhia aérea somos o maior embarcador de carga. Essa companhia aérea possui um serviço de atendimento especial para as 5 maiores contas deles, no qual nos estamos inclusos, assim, somos atendidos com prioridade.

- Em 2012 o volume dobrou devido a aquisição de uma nova empresa pela Cialab. Nesse período tivemos uns 9 meses com a operação com muitas dificuldades, geralmente uma operação no início tem no máximo 3 a 5 meses de maior dificuldade.

- Pico da operação é em março, pois nesse período o governo libera aumento nos preços dos medicamentos, assim todos os clientes da Cialab procuram comprar o estoque a fim de conseguirem o preço ainda sem o reajuste. Precisa entregar no mês para poder reconhecer como venda. Outros pontos que afetam a demanda são as férias no distribuidor que antecipam as compras.

- $70 \%$ dos distribuidores agenda cargas.

- A percepção do cliente (distribuidores) da Cialab sobre a performance é muito importante.

- Até o início de 2013 havia um problema muito grande de cargas que já saiam do centro de distribuição da Eurochain com mercadorias trocadas, faltas e sobras.

- Soubemos que Eurochain cotou nossas companhias aéreas para trabalhar direto com elas, mas provavelmente estas não devem ter aceitado o chamado pelo histórico que temos juntos.

- A Eurochain impôs que muitos transportadores teriam que colocar um equipe dentro do Centro de Distribuição da Eurochain para fazer a conferência. Nos colocamos uma equipe lá de 8 pessoas com custo Air Cargo e sem reajuste na tarifa.

- Hoje a Eurochain é o principal cliente da Air Cargo, até por acordo comercial não participamos das concorrências que eles participam, pedimos autorização para participar.

- O mercado farmacêutico exige muito, mas ainda remunera bem. 
- A Air Cargo coleta carga farmacêutica da Eurochain de 3 pontos diferentes.

- Distribuição da carga aérea farmacêutica da Eurochain antes era $60 \%$ para a Air Cargo e $40 \%$ para outros fornecedores, atualmente é $80 \%$ para Air Cargo e $20 \%$ para outros fornecedores.

- A maior parte do volume é para Norte, Nordeste e Centro-Oeste, pois apresentam maiores distâncias, Sul e Sudeste possui menor volume.

- Às vezes a Eurochain nos pede para fazer um aéreo, mas sabemos que ir pelo rodoviário será mais vantajoso, nesses casos mesmo que não ganhemos o transporte avisamos a Eurochain para que ela possa ter o melhor nível de serviço.

- Existem 5 tipos de carga;

○ - seca que é a carga comum que não precisa ser refrigerada

○ - perecível - $48 \mathrm{hr}$ de prazo para todo o Brasil, se precisar de gelo na embalagem o prazo é de $24 \mathrm{hr}$ para qualquer local do Brasil. A Air Cargo não tem autorização para abrir nenhuma caixa e nem trocar gelo.

- - Pessoa Física - cargas pequenas que são enviados direto para pessoa física

o - Vacinas que são entregues para o governo

○ - Alto valor - produtos populares que são caros e de revenda fácil, que são alvos de roubos.

- Nosso lema é chegar o mais perto do destino de avião, por isso em alguns casos não respeitamos o estado, por exemplo, atendemos muitas cidades do Rio Grande do Sul pelo aeroporto de Chapecó em Santa Catarina.

- Uma dificuldade é o extravio de carga, isso pode ocorrer nas conexões, como perda de bagagem. Em casos quando o destinatário é muito rígido e não flexibiliza para conseguir receber e a carga em questão for perecível, então toda carga perecerá. Em um caso desses a Companhia Aérea perdeu uma carga de R 280 mil, mas não conseguimos ressarcimento da Companhia Aérea, como comprar o seguro da Companhia Aérea inviabilizaria a operação, o prejuízo ficou para a Air Cargo.

- Roubo é um problema grave, pode descredenciar um transportador, tivemos um roubo, mas como era um parceiro de muitos anos, parcelamos o pagamento da carga roubada e continuamos com a operação.

- Transportador que faz a entrega final não pode armazenar carga, ele precisa coletar no aeroporto e fazer a entrega.

- O laboratório cobra rigorosamente que todos os procedimentos sejam cumpridos aqui na capital ou nos lugares mais distantes, porém em alguns locais distantes as pessoas estão tão acostumadas a receberem fora do padrão que nem reclamam com o laboratório, por exemplo, o cliente que recebe em carro de passeio ou Kombi muitas vezes já está tão acostumado que nem reclama para a Cialab. Esses transportadores não precisam ter todas as nossas licenças, pois algumas de nossas licenças tem função "guard-chuva", ou seja, serve também para as empresas que nós contratamos.

- Nós temos investido muito na estrutura das pontas, principalmente no gerenciamento do risco.

- Hoje em dia a exigência dos clientes é muito maior, todos os nossos clientes antes de 
nos contratar perguntam quais são os meus procedimentos para contratar um novo fornecedor e fazem auditoria

- (o entrevistado 1 - comentou sobre entregas difíceis e citou um caso de Santarém para Oriximina, no estado do Pará, onde a carga para chegar ao cliente final conta com 5 empresas diferentes, inclusive balsa.

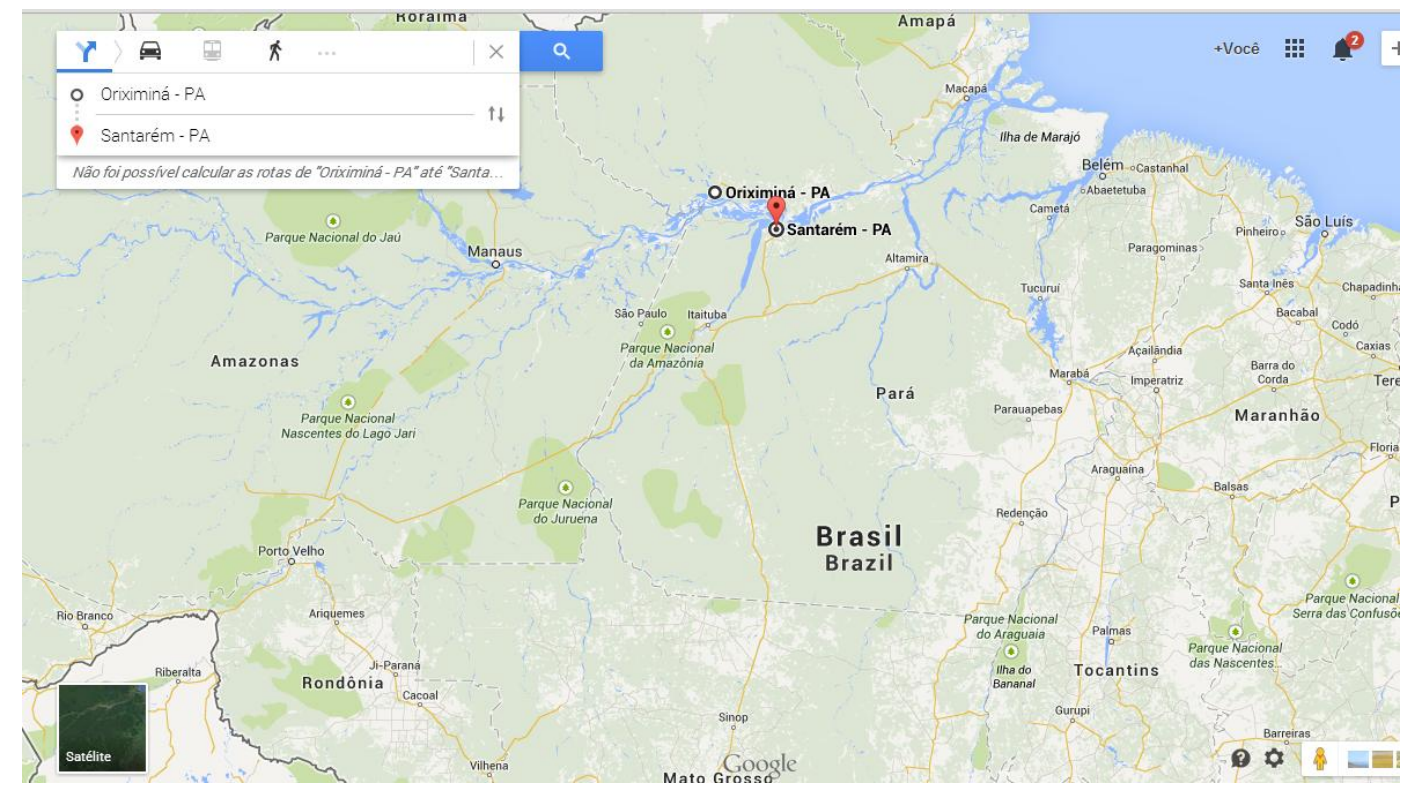

(Passo fundo no Rio Grande do Sul é atendido por Porto Alegre.

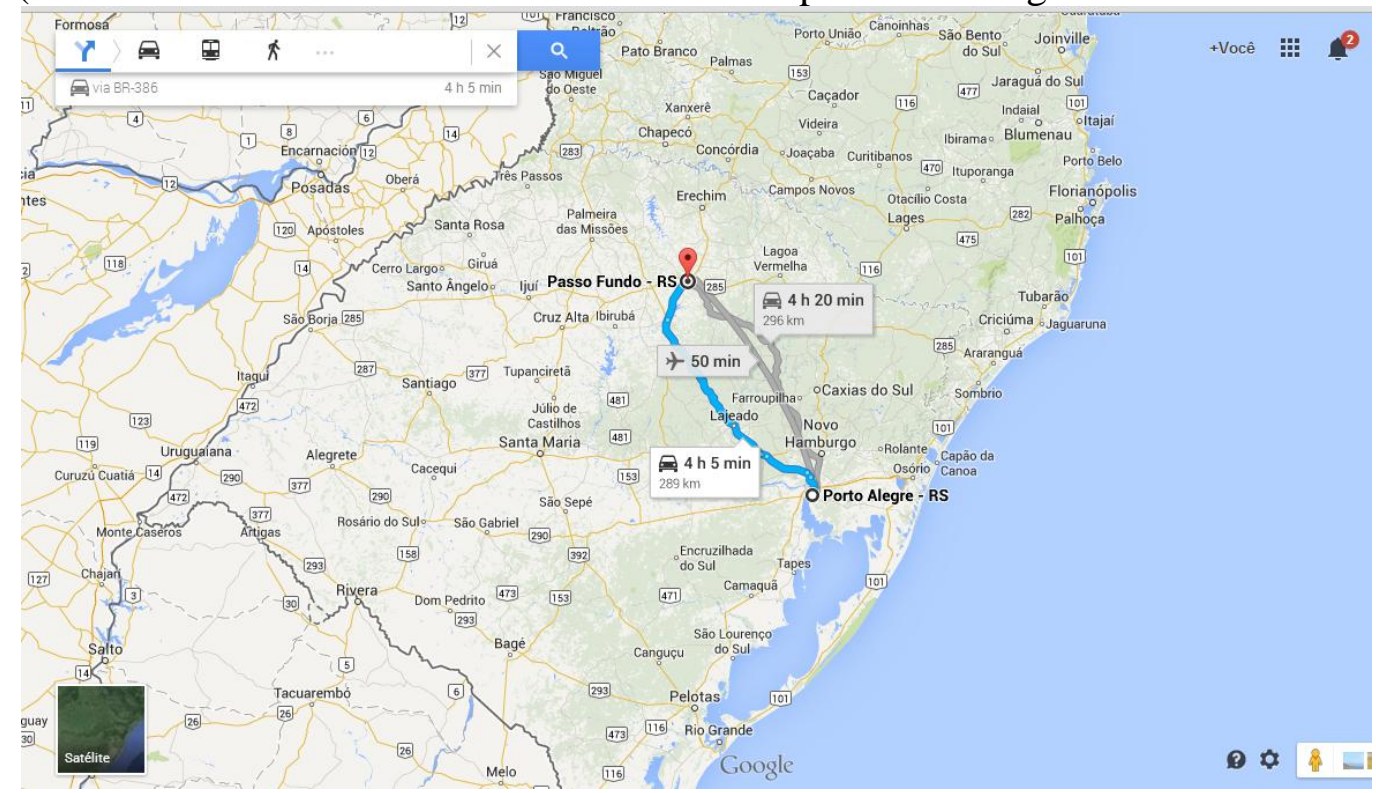

- As companhias aéreas como são poucas que operam, por exemplo, 5, mas só 2 possuem uma grande malha, essas 2 possuem grande poder nas negociação, pois não há concorrência, assim elas podem cobrar caro sem operar com muita qualidade.

- Nossa relação com a companhia aérea depende do trecho que estamos falando, se forem vôos para regiões muito movimentadas onde a companhia aérea possui grande concorrência aí temos uma briga boa, mas em trechos para região norte onde há um monopólio, aí eles tem muita força.

- Só uma companhia aera possui cargueiros, para conseguir espaço nessas aeronaves preciso dar carga de outros trechos para eles, pois espaços nos cargueiros são muito 
essenciais no final do ano.

- Temos o FOCA (facilitador operacional de carga aérea) nos principais aeroportos Congonhas, Guarulhos e Brasília.

- O pico de operação no aeroporto é das 20 às $24 \mathrm{hr}$.

- Alguns locais se você for visitar, você não vai achar tão bonito, por exemplo, Petrolina -Pernambuco e Ilhéus Bahia. (sobre qualidade das instalações dos fornecedores e da própria Air Cargo)

- Anvisa atua fortemente na auditoria dos Laboratórios, do Operador Logístico, nas transportadoras grandes, mas na companhia aérea e nos distribuidores, a ANVISA tem pouca influência.

- Nos grandes pontos de conexão como Brasília nos temos funcionários dentro dos aeroportos e uma sala lá, assim conseguimos influenciar e verificar a operação mais de perto.

- Para justificar uma construção de uma filial precisamos ter carga não só chegando, mas também saindo do estado.

- A copa do mundo não nos impactou muito, somente as cidades de grande volume, onde não tiveram jogos, nesses casos tivemos a malha da companhia aérea reduzidas.

- Nós temos um projeto para ser executado que consiste em criar uma forma de acompanhamento mais detalhado por fornecedor.

Sobre a visita

São $800 \mathrm{~m} 2$ para receber a carga farmacêutica conferir e enviar para o aeroporto, a carga farmacêutica não é armazenada na Air Cargo. Temos somente uma área climatizada para receber carga de devolução.

(- a área de farmacêutico era bem limpa e organizada

-Fora a área do farmacêutico eles possuem no mesmo terreno outro prédio de 20 mil $\mathrm{m} 2$ onde possuem a armazenagem de diversos outros produtos.

- Na Air Cargo havia a sala de gerenciamento de risco atrás de uma porta blindada.

- Havia uma sala com em torno de 9 pessoas que trabalhavam em atendimento a cliente.

- Uma outra sala de acompanhamento dos vôos e das cargas, acompanhamento da operação de coleta e separação com mais umas 9 pessoas

- no galpão tinham em torno de 7 pessoas

- No mesmo terreno havia um prédio comercial onde ficava a área administrativa da empresa, com o presidente e alta gestão.

- Neste mesmo terreno haviam diversos outros galpões muito grandes, mais de $10 \mathrm{mil}$ $\mathrm{m} 2$ com outros produtos.) 
Questionário sobre autonomia para execução do serviço

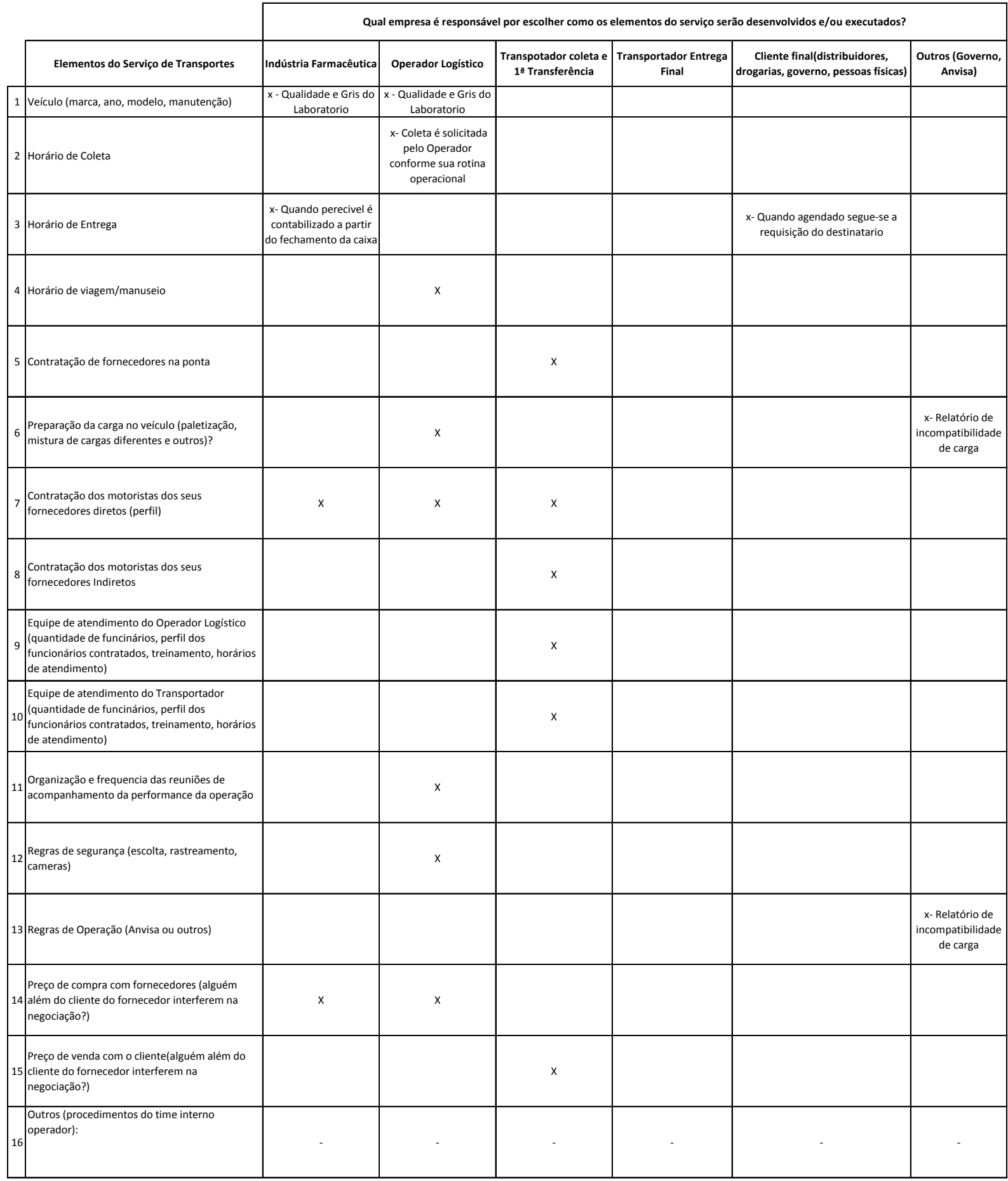

\begin{tabular}{|c|c|c|c|c|c|c|}
\hline Air Cargo & Indústria Farmacêutica & Operador Logístico & 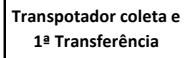 & $\begin{array}{c}\text { Transportador Entrega } \\
\text { Final }\end{array}$ & $\begin{array}{c}\text { Cliente final(distribuidores, } \\
\text { drogarias, governo, pessoas físicas) }\end{array}$ & $\begin{array}{c}\text { Outros (Governo, } \\
\text { Anvisa) }\end{array}$ \\
\hline Quantidade de Elementos & 3 & 7 & 5 & 0 & 1 & 2 \\
\hline Quais elementos & $\begin{array}{l}\text { Veículo, Horário, } \\
\text { Motorista, regras de } \\
\text { operação }\end{array}$ & \begin{tabular}{|l|} 
Veículo, Horários, \\
preparação da Carga, \\
Motorista, Equipe, \\
Reuniões, regras de \\
operação
\end{tabular} & \begin{tabular}{|l} 
Contratação de \\
Fornecedores, \\
motoristas e equipes \\
de atendimento
\end{tabular} & - & Horário de Entrega & $\begin{array}{l}\text { Preparação da } \\
\text { carga e regras de } \\
\text { Segurança }\end{array}$ \\
\hline
\end{tabular}

Comentário:

De acordo com a visão da Air Cargo existe A Eurochain tem um papel de influencia maior na opreação da cadeia, pois ela define ou participa da definição de diversos elementos do serviço de transportes. 
8.7 Anexos VII - Lista dos Artigos sobre Abordagens da Cadeia

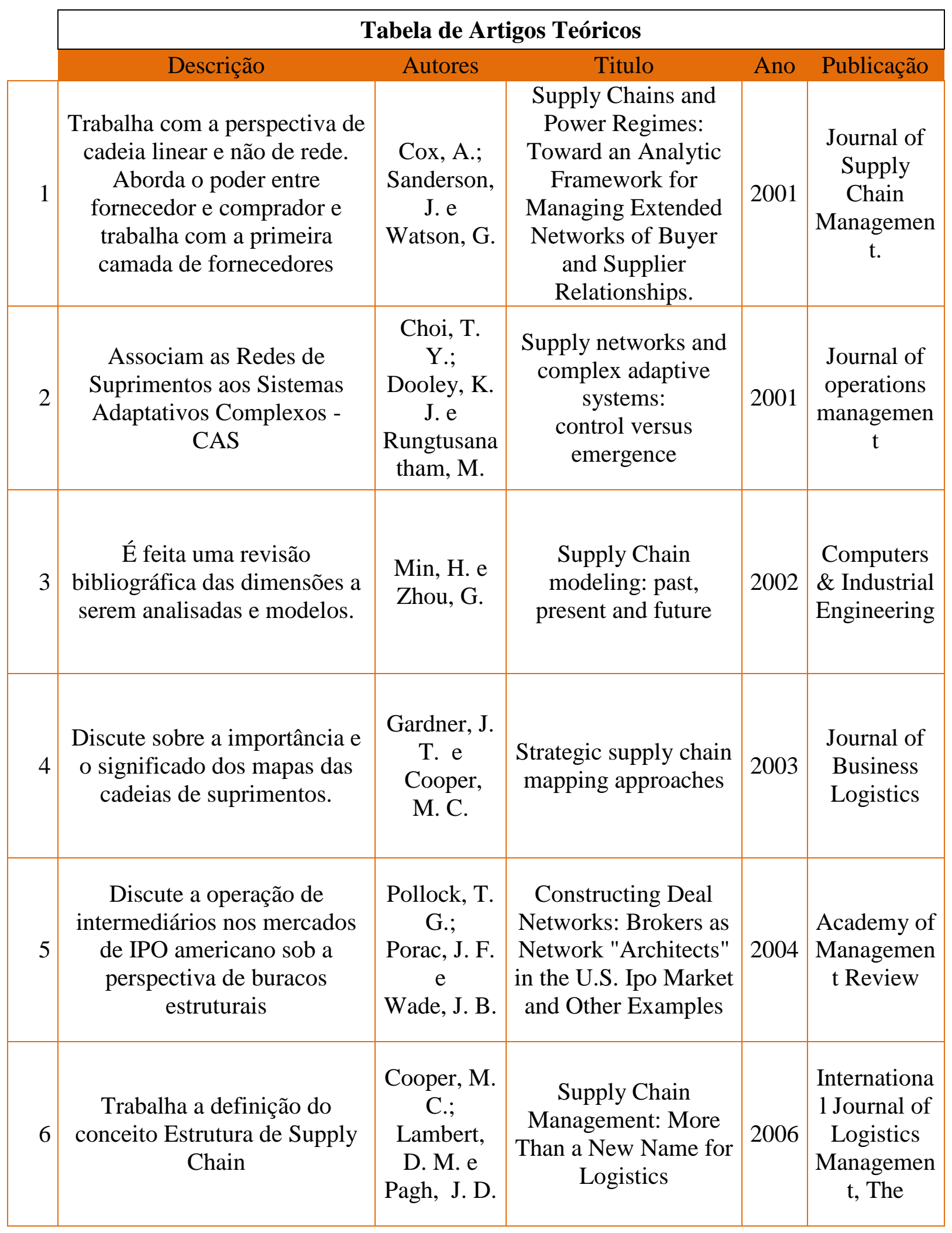




\begin{tabular}{|c|c|c|c|c|c|}
\hline 7 & $\begin{array}{c}\text { Discute a Teoria de Redes } \\
\text { para análises de Supply Chain }\end{array}$ & $\begin{array}{l}\text { Ketchen Jr, } \\
\text { D. j.; } \\
\text { Tomas G. e } \\
\text { Hult, M. }\end{array}$ & $\begin{array}{l}\text { Bridging organization } \\
\text { theory and supply } \\
\text { chain management: } \\
\text { The case of best value } \\
\text { supply chains }\end{array}$ & 2007 & $\begin{array}{c}\text { Journal of } \\
\text { Operations } \\
\text { Managemen } \\
\mathrm{t}\end{array}$ \\
\hline 8 & $\begin{array}{l}\text { Faz revisão da literatura de } \\
\text { Gestão da Cadeia de } \\
\text { Suprimentos e de CAS - } \\
\text { Complex adaptative System. } \\
\text { Relaciona a pesquisa de CAS } \\
\text { a Cadeia de Suprimentos e } \\
\text { discute as dificuldades, } \\
\text { oportunidades e futuro. }\end{array}$ & $\begin{array}{l}\text { Pathak, S. } \\
\text { D.; } \\
\text { Day, J. M.; } \\
\text { Nair, A.; } \\
\text { Sawaya, } \\
\text { W. J. e } \\
\text { Kristal, M. } \\
\text { M. }\end{array}$ & $\begin{array}{c}\text { Complexity and } \\
\text { Adaptivity in Supply } \\
\text { Networks: Building } \\
\text { Supply Network } \\
\text { Theory } \\
\text { Using a Complex } \\
\text { Adaptive } \\
\text { Systems Perspective* }\end{array}$ & 2007 & $\begin{array}{l}\text { Decision } \\
\text { Sciences }\end{array}$ \\
\hline 19 & $\begin{array}{c}\text { Utiliza Social Network } \\
\text { Analysis .SNA e destaca a } \\
\text { importância de identificar os } \\
\text { agentes ligados aos seus } \\
\text { fornecedores. }\end{array}$ & $\begin{array}{l}\text { Choi, T. Y. } \\
\text { e } \\
\text { Kim, Y. }\end{array}$ & $\begin{array}{c}\text { Strutural } \\
\text { Embeddedness and } \\
\text { supplier management: } \\
\text { a network perspective }\end{array}$ & 2008 & $\begin{array}{l}\text { Journal of } \\
\text { Supply } \\
\text { Chain } \\
\text { Managemen } \\
\text { t. }\end{array}$ \\
\hline 10 & $\begin{array}{l}\text { Aponta a importância dos } \\
\text { relacionamentos e da estrutura } \\
\text { na Cadeia de Suprimentos. } \\
\text { Também discute a importância } \\
\text { do Social Network Analysis, } \\
\text { SNA. }\end{array}$ & $\begin{array}{l}\text { Autry, } \\
\text { C.W. e } \\
\text { Griffis, } \\
\text { S.E }\end{array}$ & $\begin{array}{l}\text { Supply chain capital: } \\
\text { the impact of } \\
\text { structural and } \\
\text { relational } \\
\text { linkages on firm } \\
\text { execution and } \\
\text { innovation. }\end{array}$ & 2008 & $\begin{array}{l}\text { Journal of } \\
\text { Business } \\
\text { Logistics }\end{array}$ \\
\hline 11 & $\begin{array}{c}\text { Discute a aplicação do Social } \\
\text { Network Analysis, SNA a } \\
\text { Cadeia de Suprimentos }\end{array}$ & $\begin{array}{l}\text { Borgatti, S. } \\
\text { P. e } \\
\text { Li, X. }\end{array}$ & $\begin{array}{l}\text { On Social Network } \\
\text { Analysis in a Supply } \\
\text { Chain Context }\end{array}$ & 2009 & $\begin{array}{l}\text { Journal of } \\
\text { Supply } \\
\text { Chain } \\
\text { Managemen } \\
\text { t }\end{array}$ \\
\hline 12 & $\begin{array}{c}\text { Aponta a metodologia SONIA } \\
\text { para estudar as modificações } \\
\text { que as redes sofrem ao longo } \\
\text { do tempo }\end{array}$ & $\begin{array}{l}\text { Galaskiewi } \\
\text { cz, J. }\end{array}$ & $\begin{array}{l}\text { Studying supply } \\
\text { chains from a social } \\
\text { network perspective }\end{array}$ & 2011 & $\begin{array}{l}\text { Journal of } \\
\text { Supply } \\
\text { Chain } \\
\text { Managemen } \\
\mathrm{t}\end{array}$ \\
\hline 13 & $\begin{array}{l}\text { A Cadeia de suprimentos } \\
\text { eficiente segue a uma rede } \\
\text { "Scale-free". Cadeias de } \\
\text { suprimentos complexas - CAS }\end{array}$ & $\begin{array}{l}\text { Hearnshaw, } \\
\text { E. J.S. e } \\
\text { Wilson, M. } \\
\text { M. J. }\end{array}$ & $\begin{array}{l}\text { A complex network } \\
\text { approach } \\
\text { to supply chain } \\
\text { network theory }\end{array}$ & 2013 & $\begin{array}{c}\text { Internationa } \\
1 \text { Journal of } \\
\text { Operations } \\
\& \\
\text { Production } \\
\text { Managemen } \\
\mathrm{t} \\
\end{array}$ \\
\hline
\end{tabular}




\begin{tabular}{|c|c|c|c|c|c|}
\hline & \multicolumn{5}{|c|}{ Tabela de Artigos Qualitativos } \\
\hline & Descrição & Autores & Titulo & Ano & Publicação \\
\hline 1 & $\begin{array}{l}\text { Estudo de Caso. Destaca a } \\
\text { importância das alianças nas } \\
\text { redes, aborda o tema de } \\
\text { confiança e cooperação. }\end{array}$ & $\begin{array}{l}\text { Jarillo, J. } \\
\text { C. e } \\
\text { Stevenson, } \\
\text { H. H. }\end{array}$ & $\begin{array}{l}\text { Co-operative } \\
\text { Strategies-The } \\
\text { Payoffs and the } \\
\text { Pitfalls }\end{array}$ & 1991 & $\begin{array}{c}\text { Long Range } \\
\text { planning }\end{array}$ \\
\hline 2 & $\begin{array}{l}\text { Tecnica Delphi. Entrevistas } \\
\text { para sobre o futuro da Supply } \\
\text { Chain. São abordadas as redes } \\
\text { de cooperação. }\end{array}$ & $\begin{array}{l}\text { Harland, C. } \\
\text { M.; } \\
\text { Lamming, } \\
\text { R. C. e } \\
\text { Cousins, P. } \\
\text { D. }\end{array}$ & $\begin{array}{l}\text { Developing the } \\
\text { concept of supply } \\
\text { strategy }\end{array}$ & 1999 & $\begin{array}{l}\text { International } \\
\text { Journal of } \\
\text { Operations } \\
\& \\
\text { Production } \\
\text { Management }\end{array}$ \\
\hline 3 & $\begin{array}{l}\text { Analisa os tipos de estrutura e } \\
\text { sua relação com o tipo de } \\
\text { produto. }\end{array}$ & $\begin{array}{l}\text { Lamming, } \\
\text { R.; } \\
\text { Johnsen T.; } \\
\text { Zheng J. e } \\
\text { Harland C. }\end{array}$ & $\begin{array}{c}\text { An initial } \\
\text { classification of } \\
\text { supply networks }\end{array}$ & 2000 & $\begin{array}{l}\text { International } \\
\text { Journal of } \\
\text { Operations } \\
\& \\
\text { Production } \\
\text { Management }\end{array}$ \\
\hline 4 & $\begin{array}{c}\text { Mapeamento de Processos por } \\
\text { meio do Value Stream } \\
\text { Mapping. }\end{array}$ & Brunt D. & $\begin{array}{l}\text { From current state to } \\
\text { future state: mapping } \\
\text { the steel to component } \\
\text { supply chain }\end{array}$ & 2000 & $\begin{array}{l}\text { International } \\
\text { Journal of } \\
\text { Logistics }\end{array}$ \\
\hline 5 & $\begin{array}{c}\text { Estudo de caso com } 15 \\
\text { empresas. Propõe um modelo } \\
\text { completo para exame da Cadeia } \\
\text { de Suprimentos. Como mapear } \\
\text { agentes, dimensões estruturais } \\
\text { da rede e os tipos de } \\
\text { relacionamento. }\end{array}$ & $\begin{array}{l}\text { Lambert, } \\
\text { D. M. e } \\
\text { Cooper, M. } \\
\text { C. }\end{array}$ & $\begin{array}{l}\text { Issues in Supply } \\
\text { Chain } \\
\text { Management }\end{array}$ & 2000 & $\begin{array}{l}\text { Industrial } \\
\text { Marketing } \\
\text { Management }\end{array}$ \\
\hline 6 & $\begin{array}{c}\text { Utiliza a Estrutura } \\
\text { Organizacional (formalização, } \\
\text { centralização e complexidade) } \\
\text { para entender as cadeias de } \\
\text { Honda, Acura e } \\
\text { DaimlerChrysler. }\end{array}$ & $\begin{array}{l}\text { Choi T. Y. } \\
\text { e } \\
\text { Hong Y. }\end{array}$ & $\begin{array}{c}\text { Unveiling the } \\
\text { structure of supply } \\
\text { networks: case studies } \\
\text { in Honda, } \\
\text { Acura, and } \\
\text { DaimlerChrysler }\end{array}$ & 2002 & $\begin{array}{l}\text { Journal of } \\
\text { Operations } \\
\text { Management }\end{array}$ \\
\hline 7 & $\begin{array}{c}\text { Estudo de Caso da indústria } \\
\text { madeireira do Canadá. Dois } \\
\text { mapeamentos, um mapeamento } \\
\text { da estrutura de processos e } \\
\text { outro dos leadtimes de cada } \\
\text { processo. }\end{array}$ & $\begin{array}{l}\text { Haartveit, } \\
\text { E. Y.; } \\
\text { Kozak, R. } \\
\text { A. e } \\
\text { Maness, T. } \\
\text { C. }\end{array}$ & $\begin{array}{l}\text { Supply chain } \\
\text { management mapping } \\
\text { for the forest products } \\
\text { industry: Three cases } \\
\text { from western Canada }\end{array}$ & 2004 & $\begin{array}{l}\text { Journal of } \\
\text { Forest } \\
\text { Products }\end{array}$ \\
\hline
\end{tabular}




\begin{tabular}{|c|c|c|c|c|c|}
\hline 8 & $\begin{array}{c}\text { É feita uma análise prescritiva, } \\
\text { direcionada para tomadas de } \\
\text { decisões. }\end{array}$ & $\begin{array}{c}\text { Yee C. L.; } \\
\text { Tan, K. H. }\end{array}$ & $\begin{array}{c}\text { A process and tool for } \\
\text { supply network } \\
\text { analysis }\end{array}$ & 2004 & $\begin{array}{c}\text { Management } \\
\text { Industrial } \\
\text { + Data } \\
\text { Systems }\end{array}$ \\
\hline $\begin{array}{c}\text { Apresentam 6 metodologias de } \\
\text { Mapping. São apresentados 3 } \\
\text { casos práticos de técnicas de } \\
\text { mapeamento utilizados por } \\
\text { empresas automotivas. }\end{array}$ & $\begin{array}{c}\text { Miyake, D. } \\
\text { I.; } \\
\text { Torres Jr } \\
\text { A. S. e } \\
\text { Favaro, C. }\end{array}$ & $\begin{array}{c}\text { Supply chain mapping } \\
\text { initiatives in the } \\
\text { Brazilian automotive } \\
\text { industry: challenges } \\
\text { and opportunities }\end{array}$ & 2010 & $\begin{array}{c}\text { Journal of } \\
\text { Operations } \\
\text { and Supply } \\
\text { Chain } \\
\text { Management }\end{array}$ \\
\hline
\end{tabular}




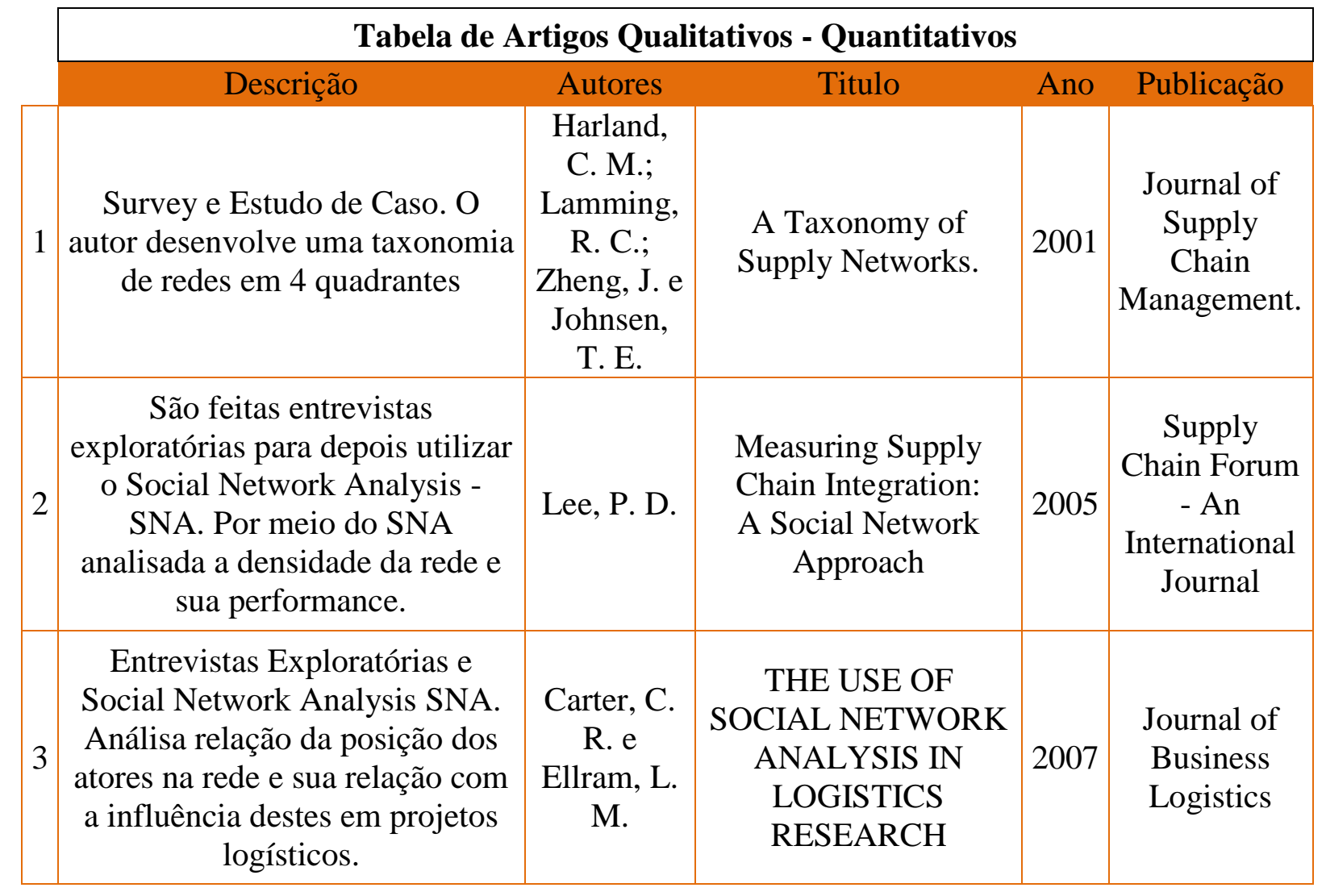




\begin{tabular}{|c|c|c|c|c|c|}
\hline & \multicolumn{5}{|c|}{ Tabela de Artigos Quantitativos } \\
\hline & Descrição & Autores & Titulo & Ano & Publicação \\
\hline 1 & $\begin{array}{c}\text { Survey para estudo da } \\
\text { relação entre estrutura da } \\
\text { Rede inovação. Empresas } \\
\text { do Canadá. }\end{array}$ & $\begin{array}{l}\text { Zaheer A. e } \\
\text { Bell, G. G. }\end{array}$ & $\begin{array}{c}\text { Benefiting from } \\
\text { Network Position: } \\
\text { Firm Capabilities, } \\
\text { Structural Holres, And } \\
\text { Performance }\end{array}$ & 2005 & $\begin{array}{c}\text { Strategic } \\
\text { Management } \\
\text { Journal }\end{array}$ \\
\hline 2 & $\begin{array}{l}\text { Utiliza Social Network } \\
\text { Analysis para entender a } \\
\text { difusão do Journal of } \\
\text { Supply Chain } \\
\text { Management entre as } \\
\text { universidades }\end{array}$ & $\begin{array}{l}\text { Carter, C. R.; } \\
\text { Leuschner, R. } \\
\text { e Rogers, D. S. }\end{array}$ & $\begin{array}{l}\text { A Social Network } \\
\text { Analysis of the } \\
\text { Journal of Supply } \\
\text { Chain Management: } \\
\text { Knowledge } \\
\text { Generation, } \\
\text { Knowledge Diffusion } \\
\text { and Thought } \\
\text { Leadership }\end{array}$ & 2007 & $\begin{array}{l}\text { The Journal } \\
\text { of Supply } \\
\text { Chain } \\
\text { Management }\end{array}$ \\
\hline 3 & $\begin{array}{l}\text { Análise de Redes para } \\
\text { verificar a quão } \\
\text { rapidamente uma empresa } \\
\text { imersa em uma rede } \\
\text { inovadora se torna } \\
\text { inovadora. }\end{array}$ & Greve, H. R. & $\begin{array}{c}\text { Bigger and Safer: The } \\
\text { Diffusion of } \\
\text { Competitive } \\
\text { Advantage }\end{array}$ & 2008 & $\begin{array}{c}\text { Strategic } \\
\text { Management } \\
\text { Journal }\end{array}$ \\
\hline 4 & $\begin{array}{c}\text { Teoria de Redes } \\
\text { complexas em uma } \\
\text { Cadeia de Suprimentos }\end{array}$ & $\begin{array}{l}\text { Keqiang, W.; } \\
\text { Zhaofeng, Z. e } \\
\text { Dongchuan, S. }\end{array}$ & $\begin{array}{l}\text { Structure Analysis of } \\
\text { Supply Chain } \\
\text { Networks Based } \\
\text { on Complex Network } \\
\text { Theory }\end{array}$ & 2008 & $\begin{array}{c}\text { Fourth } \\
\text { International } \\
\text { Conference } \\
\text { on } \\
\text { Semantics, } \\
\text { Knowledge } \\
\text { and Grid } \\
\end{array}$ \\
\hline 5 & $\begin{array}{c}\text { Utiliza Sociol Network } \\
\text { Analysis para investigar o } \\
\text { Estudo de Caso de Honda, } \\
\text { Acura e } \\
\text { DAimlerChryslert (Kim e } \\
\text { Choi, 2002). }\end{array}$ & $\begin{array}{l}\text { Kim, Y.; } \\
\text { Choi, T. Y.; } \\
\text { Yan, T. e } \\
\text { Dooley, K. }\end{array}$ & $\begin{array}{c}\text { Structural } \\
\text { investigation of supply } \\
\text { networks: A social } \\
\text { network analysis } \\
\text { approach }\end{array}$ & 2010 & $\begin{array}{l}\text { Journal of } \\
\text { Operations } \\
\text { Management }\end{array}$ \\
\hline
\end{tabular}

\subsection{Anexos VIII - Aspectos da estrutura da Cadeia de Suprimentos Identificados por Artigo}




\begin{tabular}{|c|c|c|c|c|c|c|}
\hline & Integração & Formalização & $\begin{array}{l}\text { Complexida- } \\
\text { de }\end{array}$ & Centralização \\
\hline \multirow{8}{*}{ 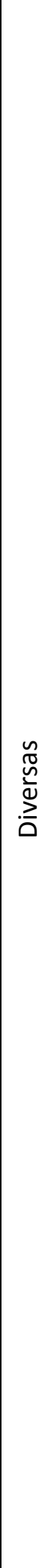 } & 1 & $\begin{array}{c}\text { Jarillo, J. C. e } \\
\text { Stevenson, H. } \\
\text { H. (1991) }\end{array}$ & $\begin{array}{c}\text { cooperação, } \\
\text { relacionamento } \\
\text { próximo a } \\
\text { fornecedores, } \\
\text { relação de longo } \\
\text { prazo, } \\
\text { investimento na } \\
\text { confiança }\end{array}$ & & & \\
\hline & 2 & $\begin{array}{l}\text { Harland, C. } \\
\text { M.; Lamming, } \\
\text { R. C. e } \\
\text { Cousins, P. D. } \\
\text { (1999) }\end{array}$ & $\begin{array}{l}\text { compartilhament } \\
\text { o de informações }\end{array}$ & & $\begin{array}{c}\text { grau de } \\
\text { complexidade }\end{array}$ & $\begin{array}{l}\text { Concentração } \\
\text { de Poder } \\
\text { Influência sobre } \\
\text { agentes chaves } \\
\text { da cadeia }\end{array}$ \\
\hline & 3 & $\begin{array}{c}\text { Lamming, R.; } \\
\text { Johnsen T.; } \\
\text { Zheng J. e } \\
\text { Harland } \\
\text { C.(2000) } \\
\end{array}$ & $\begin{array}{c}\text { compartilhament } \\
\text { o de informações } \\
\text { e recursos }\end{array}$ & $\begin{array}{l}\text { processos } \\
\text { estáveis }\end{array}$ & & \\
\hline & 4 & $\begin{array}{l}\text { Gardner, J. T. } \\
\text { e Cooper, M. } \\
\text { C. }(2003)\end{array}$ & $\begin{array}{l}\text { Processo de } \\
\text { Integração da } \\
\text { Cadeia }\end{array}$ & & & \\
\hline & 5 & $\begin{array}{l}\text { Zaheer A. e } \\
\text { Bell, G. } \\
\text { G.(2005) }\end{array}$ & $\begin{array}{l}\text { alianças } \\
\text { estratégicas }\end{array}$ & & & $\begin{array}{c}\text { Posição na } \\
\text { cadeia ajuda a } \\
\text { influênciar } \\
\text { outras } \\
\text { empresas. }\end{array}$ \\
\hline & 6 & \begin{tabular}{|c|} 
Harland, C. \\
M.; Lamming, \\
R. C.; Zheng, J. \\
e Johnsen, T. \\
E.(2001) \\
\end{tabular} & $\begin{array}{l}\text { cooperação, } \\
\text { relações de } \\
\text { colaboração }\end{array}$ & & & \\
\hline & 9 & $\begin{array}{c}\text { Cox, A.; } \\
\text { Sanderson, J. } \\
\text { e Watson, } \\
\text { G.(2001) }\end{array}$ & & $\begin{array}{l}\text { Regras (operam } \\
\text { segundo conjunto } \\
\text { de regras) }\end{array}$ & $\begin{array}{c}\text { Redes } \\
\text { Complexas }\end{array}$ & $\begin{array}{c}\text { relação de } \\
\text { poder, } \\
\text { dominância do } \\
\text { fornecedor ou } \\
\text { comprador }\end{array}$ \\
\hline & 10 & $\begin{array}{l}\text { Ketchen Jr, D. } \\
\text { j.; Tomas G. e } \\
\text { Hult, M.(2007) }\end{array}$ & $\begin{array}{c}\text { alinhamento } \\
\text { entre os } \\
\text { interesses de } \\
\text { todas as empresas }\end{array}$ & $\begin{array}{l}\text { contratos (para } \\
\text { assegurar } \\
\text { compartilhament } \\
\text { o de riscos) }\end{array}$ & & \\
\hline 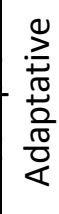 & 11 & $\begin{array}{l}\text { Keqiang, W.; } \\
\text { Zhaofeng, Z. e } \\
\text { Dongchuan, } \\
\text { S.(2008) }\end{array}$ & & & $\begin{array}{c}\text { Redes } \\
\text { Complexas }\end{array}$ & \\
\hline
\end{tabular}




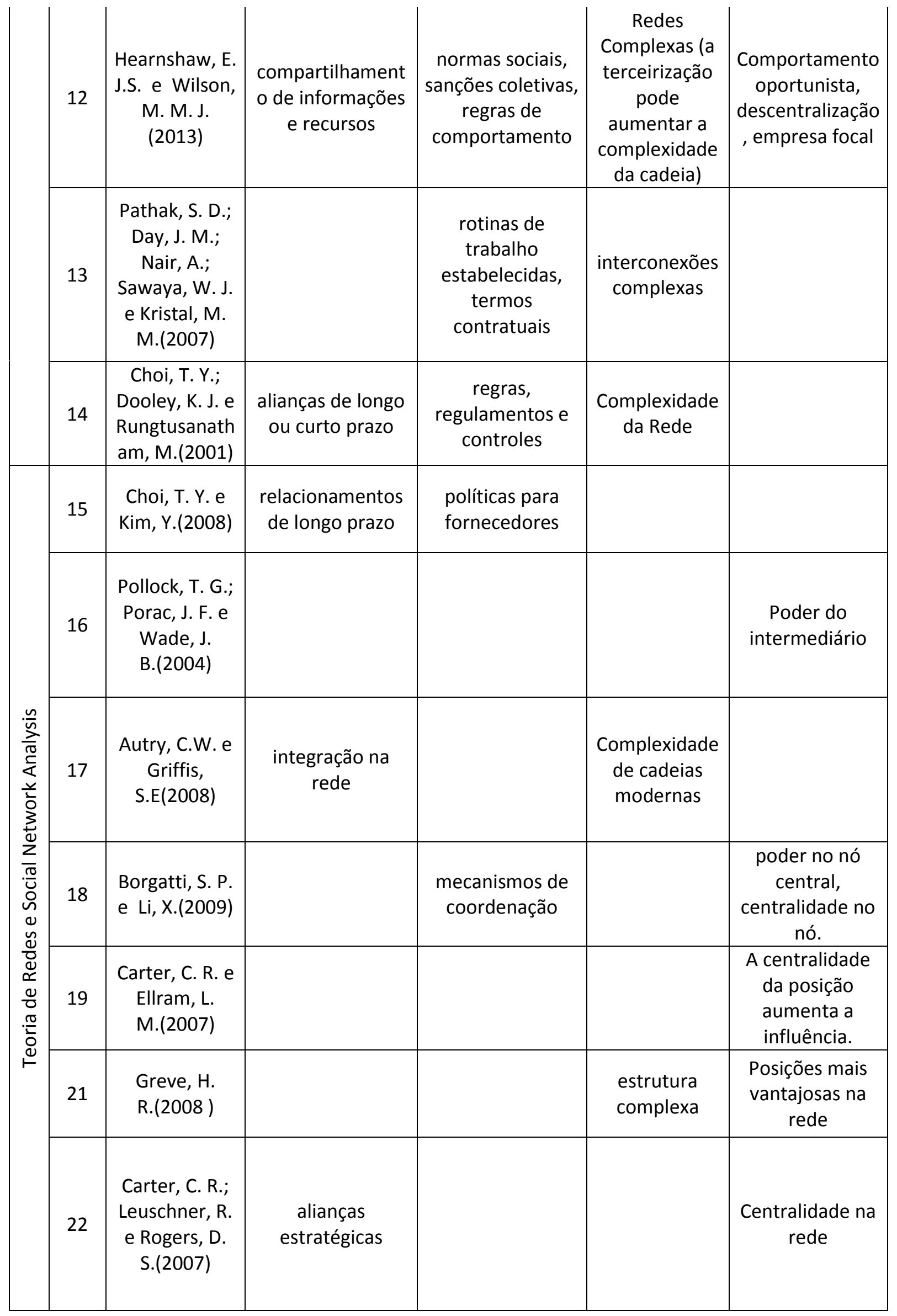




\begin{tabular}{|c|c|c|c|c|c|c|}
\hline & 23 & $\begin{array}{l}\text { Lee, P. } \\
\text { D.(2005) }\end{array}$ & $\begin{array}{l}\text { Integração, ações } \\
\text { colaborativas, } \\
\text { allianças } \\
\text { estratégicas }\end{array}$ & & $\begin{array}{l}\text { Cadeia de } \\
\text { Suprimentos } \\
\text { complexa } \\
\text { (figura 1) }\end{array}$ & $\begin{array}{l}\text { Centralidade na } \\
\text { rede, centros de } \\
\text { poder }\end{array}$ \\
\hline & 24 & \begin{tabular}{|c|} 
Kim, Y.; Choi, \\
T. Y.; Yan, T. e \\
Dooley, \\
K.(2010)
\end{tabular} & $\begin{array}{l}\text { Compartilhament } \\
\text { o de Riscos (tipo } \\
\text { de conexão) }\end{array}$ & $\begin{array}{l}\text { relações } \\
\text { contratuais }\end{array}$ & $\begin{array}{c}\text { Complexidade } \\
\text { da Rede }\end{array}$ & $\begin{array}{c}\text { Posição Central } \\
\text { do Nó }\end{array}$ \\
\hline & 25 & $\begin{array}{c}\text { Galaskiewicz, } \\
\text { J.(2011) }\end{array}$ & Confiança & $\begin{array}{c}\text { Regras, } \\
\text { Obrigações e } \\
\text { Normas, } \\
\text { contratado } \\
\text { detalhado }\end{array}$ & & \\
\hline & 27 & $\begin{array}{l}\text { Min, H. e } \\
\text { Zhou, G. } \\
(2002)\end{array}$ & $\begin{array}{c}\text { Colaboração, } \\
\text { compartilhament } \\
\text { o de informações, } \\
\text { mitigação de } \\
\text { riscos. }\end{array}$ & & $\begin{array}{c}\text { Dimensão } \\
\text { estrutural } \\
\text { vertical e } \\
\text { horizontal. }\end{array}$ & \\
\hline & 28 & $\begin{array}{l}\text { Cooper, M. C.; } \\
\text { Lambert, D. } \\
\text { M. e Pagh, J. } \\
\text { D. (2006) }\end{array}$ & $\begin{array}{c}\text { Integração, } \\
\text { comprometiment } \\
\text { o de longo prazo }\end{array}$ & & $\begin{array}{c}\text { Dimensão de } \\
\text { comprimento } \\
\text { e quantidade } \\
\text { de } \\
\text { participantes } \\
\text { na cadeia } \\
\end{array}$ & \\
\hline 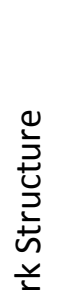 & 29 & $\begin{array}{l}\text { Lambert, D. } \\
\text { M. e Cooper, } \\
\text { M. C. (2000) }\end{array}$ & $\begin{array}{l}\text { Integração e } \\
\text { gerenciamento de } \\
\text { processos chaves } \\
\text { por meio da } \\
\text { cadeia. }\end{array}$ & $\begin{array}{c}\text { Definição de } \\
\text { métricas para } \\
\text { avaliação de } \\
\text { desempenho da } \\
\text { cadeia. }\end{array}$ & $\begin{array}{l}\text { Dimensão de } \\
\text { comprimento } \\
\text { e quantidade } \\
\text { de clientes e } \\
\text { fornecedores } \\
\text { por nível }\end{array}$ & $\begin{array}{l}\text { Influência d } \\
\text { euma agente } \\
\text { com poder. }\end{array}$ \\
\hline 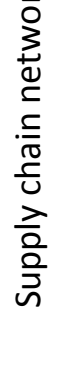 & 31 & $\begin{array}{c}\text { Haartveit, E. Y. } \\
\text {; Kozak, R. A. e } \\
\text { Maness, T. C. } \\
\text { (2004) }\end{array}$ & $\begin{array}{c}\text { Colaboração e } \\
\text { integração entre } \\
\text { atores. } \\
\text { Compartilhament } \\
\text { o de informações. } \\
\text { Confiança. } \\
\text { Compartilhament } \\
\text { o de riscos. }\end{array}$ & & $\begin{array}{l}\text { Cadeia Longa } \\
\text { e Complexa } \\
\text { com diversos } \\
\text { intermediários }\end{array}$ & \\
\hline & 32 & $\begin{array}{c}\text { Miyake, D. } \\
\text { I.;Torres Jr A. } \\
\text { S. e Favaro, C. } \\
\text { (2010) }\end{array}$ & $\begin{array}{l}\text { Dificuldade para } \\
\text { trabalhar em } \\
\text { conjunto com } \\
\text { fornecedores. } \\
\text { Confiança e } \\
\text { compartilhament } \\
\text { o de informações. } \\
\text { Parceria real e } \\
\text { rica comunicação. } \\
\text { Compromissos } \\
\text { mutuos de longo } \\
\text { prazo. }\end{array}$ & $\begin{array}{c}\text { Transparência } \\
\text { com formalização } \\
\text { no } \\
\text { relacionamento. }\end{array}$ & & $\begin{array}{l}\text { Poder de } \\
\text { barganha }\end{array}$ \\
\hline
\end{tabular}




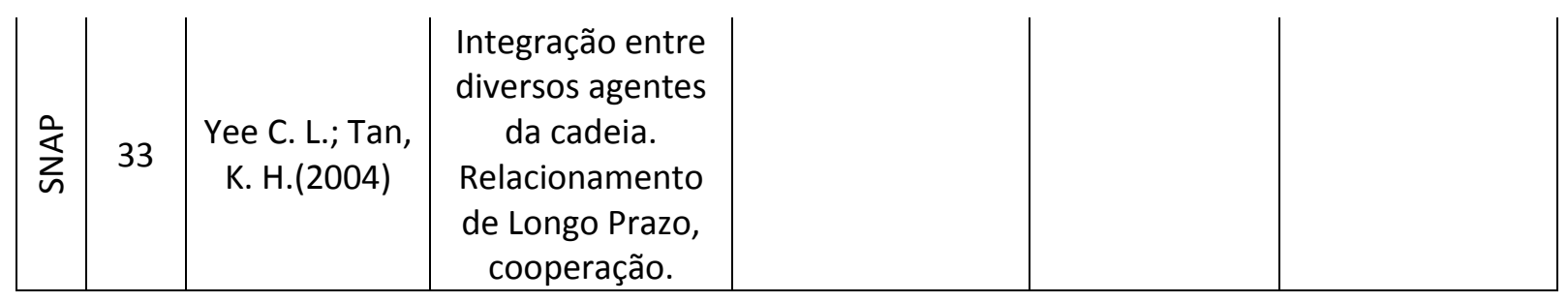

